ONTOGENIA DE Iguana iguana (Linnaeus, 1758): ESTÁGIOS EMBRIONÁRIOS E DESENVOLVIMENTO DO ESQUELETO

DOUTORANDO: FABIANO CAMPOS LIMA

ORIENTADOR: DR. ANTONIO SEBBEN

BRASÍLIA - DF

JUNHO, 2015 


\title{
ONTOGENIA DE Iguana iguana (Linnaeus, 1758): ESTÁGIOS EMBRIONÁRIOS E DESENVOLVIMENTO DO ESQUELETO
}

\author{
FABIANO CAMPOS LIMA
}

Tese apresentada ao Programa de PósGraduação em Biologia Animal do Instituto de Ciências Biológicas da Universidade de Brasília com requisito parcial para obtenção do título de Doutor em Biologia Animal.

ORIENTADOR: DR. ANTONIO SEBBEN

BRASÍLIA - DF

JUNHO, 2015 


\title{
UNIVERSIDADE DE BRASÍLIA
}

Instituto de Ciências Biológicas

Programa de Pós-Graduação em Biologia Animal

\author{
FABIANO CAMPOS LIMA
}

Título da Tese

\section{Ontogenia de Iguana iguana (Linnaeus, 1758): Estágios Embrionários e Desenvolvimento do Esqueleto}

\author{
Prof. Dr. Antonio Sebben \\ Presidente/Orientador \\ $\mathrm{UnB}$ \\ Prof. Dr. Eduardo Maurício Mendes de Lima \\ Membro Efetivo Externo \\ UnB \\ Profa. Dra. Lilian Gimenes Giugliano \\ Membro Efetivo Externo \\ UnB \\ Profa. Dra. Aline Pic-Taylor \\ Membro Efetivo Interno \\ $\mathrm{UnB}$ \\ Prof. Dr. Osmindo Rodrigues Pires Junior \\ Membro Efetivo Interno \\ UnB
}

Profa. Dra. Jussara Rocha Ferreira

Membro Suplente

$\mathrm{UnB}$

Brasília, 23 de Junho de 2015 
Existe um único caminho que nos leva a plenitude e a herança que o mundo nos permite: o conhecimento. 


\section{AGRADECIMENTOS}

Nenhuma grande jornada pode ser concluída sem que muitos personagens tenham participado dela. Poder expressar gratidão por aqueles que tornaram sua trajetória mais exequível é motivo de satisfação, pois nem todos são gratos àqueles que o ajudaram a transpor as pedras em seu caminho.

Sou imensamente grato ao meu orientador, o professor Antonio Sebben, que desde o primeiro dia depositou confiança em mim, um rapaz franzino que apareceu do nada com o objetivo de se tornar um doutor. Não existe um dia apenas que não reconheço o mérito deste homem que deposita na formação de novos profissionais a vontade de tornar a ciência algo mais próximo de todos. Muito obrigado professor pela dedicação e confiança.

Muito obrigado aos colegas do laboratório.

Muitíssimo obrigado a Tainã, alguém que considero mais que amiga, parte de uma família que formei ao longo de minha jornada. Foram muitas risadas, trabalho sério, troca de ideias e sobretudo muito cumplicidade vindo de alguém que poderia simplesmente me negar um sorriso, mas pelo contrário, me abriu portas e segurou em minha mão.

Sou grato ao professor Osmindo por me acolher, aconselhar e partilhar comigo seus ensinamentos. Poder conviver com ambos foi um ensaio ímpar que pretendo carregar comigo, pois a experiência de vida adquirida durante este período me amadureceu e me despertou.

Poder contar com amigos como a Lucélia, que desde o primeiro dia foi sem dúvida minha grande inspiração de vida, me tornou alguém mais sábio e forte. Seu exemplo guia minha carreira e meus objetivos são traçados segundo uma perspectiva única que atribuo a este grande ser. Mais que oferecer seu aparo acadêmico ela sempre esteve presente nos momentos mais alegres e difíceis dessa empreitada e sua voz, as vezes dura de ser ouvida, me confortou e direcionou a este momento.

Aos meus grande amigos Ricardo Santa Rita e Kleber Fernando pelo suporte, primeiro enquanto profissional, mais adiante enquanto ser humano. Poder contar com a força de ambos durante esse período me motivou a cada dia. Pensar em desistir me ocorreu em vários momentos. Idas e vindas, aulas, muito trabalho, experimentos frustrados... Muitas foram as dificuldades mas o exemplo de vocês me deixou resistente as intempéries. Sem dúvida vocês dois foram as pessoas que me acolheram na UFG e me mostraram que posso crescer e me sentir seguro neste lugar.

Muito obrigado a Dayane pelos momentos de alegria e muita conversa. Pela força com as disciplinas da Anatomia nessa hora difícil e por ser esse indivíduo iluminado. 
Muito obrigado aos profissionais que me cederam a oportunidade de trabalhar em seus laboratórios, por compartilhar seu conhecimento, equipamentos, espaço e recursos para que minha investigação tivesse êxito. Alessandra Feijó, Fabiana Melo, Lilian Cristina, André Quagliatto, Jorge Diniz e muitos outros.

Reconhecimento especial ao professor Augusto Abe e a Marina Sartori por possibilitar a coleta de embriões e pela contribuição mais que inestimável neste trabalho.

Sou agradecido a meus amigos que sempre me suportaram nos momentos de crise e angústia e me cederam o ombro para que eu secasse as lágrimas e voltasse a caminhar. Magrelo, Zannan, Fran, Thaís, Mizael, Darlan, Sandra, Douglas, Maria, Gustavo, Cristiane, Érica, Cristielle, Mariluce, Éder e outros que, embora não tenha elencado nesse papel, certamente foram importantes nesse processo. Cada um com sua parcela de contribuição, mas sem vocês certamente eu não seria um décimo da pessoa que sou.

Muito obrigado a minha família pelo suporte e por entender que a vida acadêmica nem sempre reserva espaço para presença em datas especiais, férias ou finais de semana. Muito obrigado pai e mãe pela maneira que conduziram minha educação, me orientando a ser uma pessoa ética e que busca seus objetivos. Grato pelo suporte de minhas irmãs Dany e Cissa que sempre estiveram presentes, mesmo quando eu estive ausente visto tantas obrigações e responsabilidades.

Ao meu estimado amigo Gordo meu sincero obrigado pelo carinho e dedicação. Muitas foram as horas de conversa sobre qualquer assunto, útil ou banal, mas que me deixaram imensamente grato pela existência desse ser maravilhoso em minha vida e que tornou meus dias em Jataí mais agradáveis. Obrigado pelas experiências de vida, pelas horas de risadas, pelas broncas.

Muito obrigado ao Odeony que nessa fase final esteve presente nas crises de ansiedade me confortando e me incentivando a vencer. Obrigado por me ensinar a viver e por partilhar experiências ímpares comigo. Estar vivo nos obriga a sermos fortes para vencer os obstáculos e conquistar nossos objetivos.

Agradeço a UnB e UFG enquanto instituição de ensino pela oportunidade de crescimento profissional e aprimoramento.

Muito obrigado a todos pela oportunidade de partilhar conhecimento e por me tornar um homem que luta por seus sonhos. 


\section{SUMÁRIO}

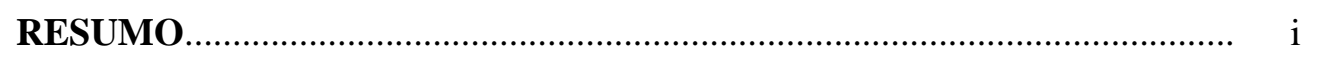

ABSTRACT

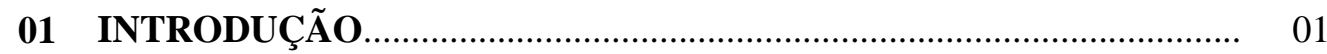

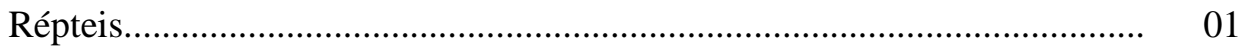

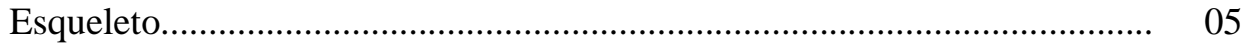

Estágios embrionários.............................................................................. 11

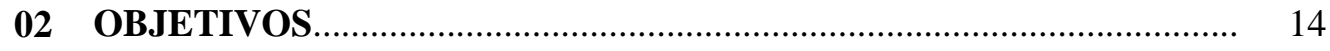

2.1 Objetivo geral............................................................................... 14

2.2 Objetivos específicos.................................................................. 14

03 MATERIAL E MÉTODOS................................................................ 15

3.1 Manutenção dos ovos e Coleta dos embriões........................................... 15

3.2 Determinação dos estágios de desenvolvimento....................................... 16

3.3 Diafanização e coloração de ossos e cartilagens....................................... 17

3.4 Preparação e descrição do esqueleto adulto............................................. 18

3.5 Investigação histológica.......................................................................... 18

3.6 Terminologia adotada....................................................................... 19

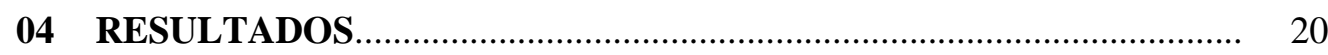

4.1 Descrição anatômica do esqueleto adulto.............................................. 20

4.2 Determinação dos estágios embrionários.............................................. 65

4.3 Ontogenia do esqueleto.......................................................................... 76

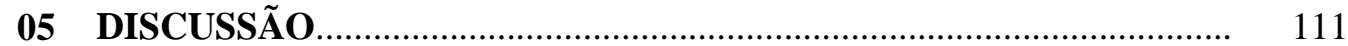

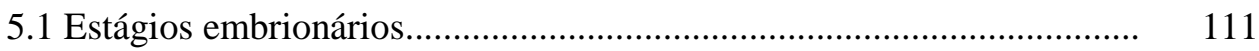

5.2 Anatomia e ontogenia do esqueleto...................................................... 119

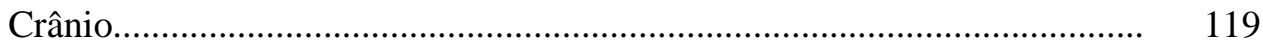

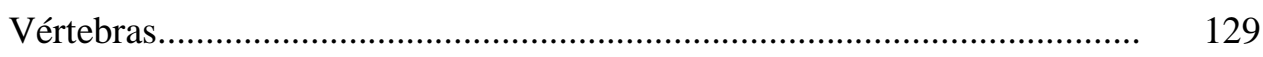

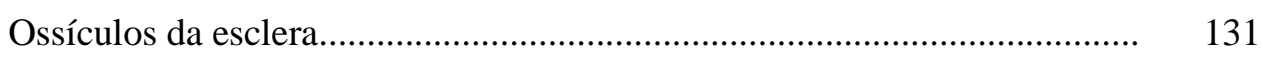

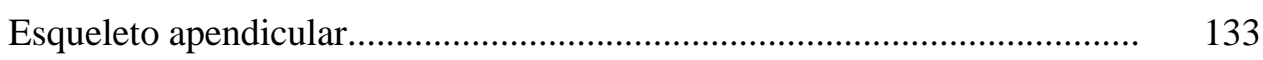

Membro torácico.................................................................................... 134

Membro pelvino....................................................................................... 144

06 CONSIDERAÇÕES FINAIS ............................................................ 148

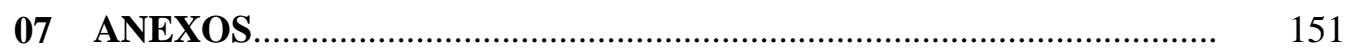

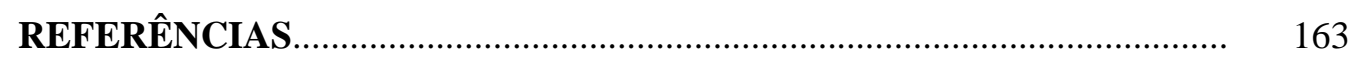




\section{LISTA DE FIGURAS}

Figura 1 Representação da filogenia para Squamata baseada em dados moleculares. Adaptado: Pyron et al., 2013.

Figura 2 Representação esquemática das estruturas de origem embrionária do tecido ósseo. A, corte transversal do embrião evidenciando a topografia das estruturas do tubo neural (tn), mesoderma paraxial (mp), mesoderma intermediário (mi), mesoderma lateral (ml), crista neural (cn) e notocorda (nt). B, esquema em vista dorsal do embrião. $\mathrm{C}$, esquema em vista lateral do embrião. As setas indicam as estruturas do esqueleto adulto formadas pelas respectivas estruturas no embrião. Adaptado: Gilbert, 2006. Embrião de Melanoshucus

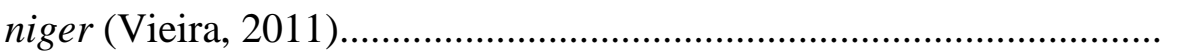

Figura 3 A, Reconstrução tridimensional do crânio adulto de Physianathus cocincinus. Maisano, 2015 (Disponível em: digimorph.org). Representação esquemética do globo ocular de répteis $(\mathrm{C})$ em corte transversal (B). C, córnea; Cc, corpo ciliar; Co, coróide; Es, esclera; F, fovea; I, iris; L, lente; OE, ossículos da esclera; R, retina........... 08

Figura 4 Desenvolvimento do broto dos membros em Tetrapoda. Representação esquemática da formação da Crista Apical Ectodermal. Corte transversal do broto do membro evidenciando a AER. Fotografias do desenvolvimento do membro. Adaptado: Arcangelis et al., 2000; Casanova et al., 2015

Figura 5 Representação esquemática da condensação cartilagínea dos membros em Tetrapoda. As estruturas marcadas pela cor escura representam o eixo primário, tal como evidencia o traço de maior espessura. As demais estruturas marcadas com cor clara e traços menos espessos formam o arco digital. $\mathrm{O}$ dígito $\mathrm{V}$ se forma por condensação independente, tal como as demais estruturas da região central do autopódio. Embora os elementos centrais tenham sido representados por apenas um componente, esta não corresponde a quantidade de estruturas. r, rádio; ra, radial; u, ulna; ul, ulnar; f, fíbula; fi, fibular; t, tíbia; ti, tibial; c, central; i, intermédio; dc4, distal do carpo 4; dt4, distal do tarso 4. Adaptado: Shubin e Alberch, 1986..

Figura 6 Crânio de I. iguana iguana adulta. Vista dorsal (A) e lateral (B). Pm, pré-maxila; Na, nasal; Ma, maxila; La, lacrimal; Prf, pré-frontal; Ju, jugal; Fr, frontal; Ec, ectopterigóide; Pt, pterigoide; Pl, palatino; Ep, epipterigóide; Pof, pós-frontal; Po, pós-orbital; Pa, parietal; Es, esquamosal; Ba, basisfenóide; Qu, quadrado; So, supraoccipital; Ot, 
Figura 7 Crânio de I. iguana iguana adulta. Vista ventral (A) e caudal (B). Pm, pré-maxila; Vo, vômer; Ma, maxila; Ju, jugal; Ec, ectopterigóide; Pl, palatino; Pt, pterigóide; Po, pós-orbital; Es, esquamosal; Bo, basioccipital; Eo, exoccipital; Ot, otoccipital; $\mathrm{Qu}$, quadrado; $\mathrm{Pb}$, parabasisfenóide; Bp, basipterigóide; St, supratemporal

Figura 8 Ossículos da esclera de I. iguana iguana adulta.

Figura 9 Mandíbula de I. iguana iguana adulta. Vista dorsal (A), ventral (B), lateral (C) e medial (D). De, dentário; Co, coronóide; Sa, suprangular; An, angular; Par, pré-articular; Ar, articular; Ep, esplenial; Pra, processo retroarticular; Pan, processo angular.

Figura 10 Aparelho hióide de I. iguana iguana adulta

Figura 11 Vértebras de I. iguana iguana adulta. A-C segmento dorsal; D, segmento caudal e E segmento sacral. av, arco vertebral; cv, centro vertebral; ch, processo hemal; cs, costela sacral; fv, forame vertebral; pca, processo articular caudal; pcr, processo articular cranial; pt, processo transverso

Figura 12 Vértebras cervicais de I. iguana iguana adulta. Vista lateral (A), superior (B), cranial (C) e caudal (D). Vista lateral, em posição anatômica, do segmento cervical com suas respectivas costelas (E).....

Figura 13 Vértebras cervicais de I. iguana iguana adulta. Atlas, vista cranial (A), vista caudal (B). Áxis, vista lateral (C), vista cranial (D) e vista caudal (E). Vista lateral das duas primeiras vértebras cervicais em posição anatômica $(\mathrm{F})$

Figura 14 Vértebras dorsais de I. iguana iguana adulta. Vista lateral (A), dorsal (B), cranial (C) e caudal (D). Vértebras dorsais D12, D13 e D14 e suas respectivas costelas em vista lateral $(\mathrm{E})$

Figura 15 Vértebras lombares de I. iguana adulta. Vista lateral (A), dorsal (B), cranial (C) e caudal (D). Vista lateral, em posição anatômica, das vértebras do segmento lombar e suas respectivas costelas (E)..............

Figura 16 Vértebras sacrais de I. iguana iguana adulta. Vista cranial (A), caudal (B), lateral (C), ventral (D) e dorsal (E)

Figura 17 Vértebras caudais de I. iguana adulta. Porção proximal em vista 
lateral (A), cranial (B), caudal (C) e dorsal (D). Vértebra caudal da porção média (E) e porção distal $(\mathrm{F})$......

Figura 18 Vista lateral das vértebras do segmento caudal de I. iguana adulta......

Figura 19 Costelas, vértebras dorsais, esterno e interclavícula de I. iguana adulta.

Figura 20 Ossos da cintura peitoral e membros torácicos de I. iguana. Escápula e coracóide, vista dorsolateral (A), ventromedial (B) e detalhe da superfície articular em vista cranial (B'). Úmero, vista lateral (C), ulna, vista medial (D) e lateral (E) e rádio.

Figura 21 Detalhe do esqueleto da extremidade distal do membro torácico de $I$. iguana iguana adulta. Vista dorsal. u, ulnar; r, radial; Dc, distais do carpo; c, central; i, intermédio; mcI, metacarpo I. Barra: 3,35mm........

Figura 22 Esqueleto da extremidade distal do membro torácico de I. iguana iguana adulta. Vista dorsal (A) e palmar (B) da mão. Digítos I, II, III, IV e V. F, falanges; Mc, metacarpos; u, ulnar do carpo; r, radial do carpo; DcII, distal do carpo II; DcIII, distal do carpo III; DcIV, distal do carpo IV; DcV, distal do carpo V; C, central; I, intermédio; Pi, pisiforme. Barra $2 \mathrm{~cm}$.

Figura 23 Ossos da cintura pélvica e membros pelvinos de I. iguana adulta. Pelve óssea em vista ventral (A), dorsal (B), lateral (C) e detalhe da vista medial ao nível da articulação dos ossos ilíaco, púbis e ísquio na face interna da fossa do acetábulo (B'). Fêmur em vista lateral (D) e medial (E). Tíbia, vista cranial (F) e caudal (G). Fíbula em vista cranial $(\mathrm{H})$

Figura 24 Esqueleto da extremidade distal do membro pelvino de I. iguana adulta. Vista dorsal (A) e plantar (B) do pé. Artelhos I, II, III, IV e V. F, falanges; Mt, metatarsos, DTIII, distal do tarso III; DtIV, distal do tarso IV; PxT; proximal do tarso.

Figura 25 Desenvolvimento de embriões de I. iguana iguana. Microscopia eletrônica de varredura. A; estágio 28 (com abertura do tubo neural, cabeça da seta). B; estágio 31. C; estágio 32. D; estágio 33. Me, mesencéfalo; Di, diencéfalo; Te, telencéfalo; Co, coração; Ps, pálpebra superior. Barra $300 \mu \mathrm{m}$.

Figura 26 Detalhes do desenvolvimento dos embriões de I. iguana iguana. A, estágio 28. B, estágio 29. C, estágio 31. D, estágio 33. E, estágio 35. 
F, estágio 34. G, estágio 30. af, arcos faríngeos (* processo maxilar); at, átrio; co, coração; pg, papila genital; ve, ventrículo. Barra: $4 \mathrm{~mm}$....

Figura 27 Embriões de I. iguana iguana. A; estágio 28. B; estágio 29. C; estágio 30. D; estágio 31. E; estágio 32. F; estágio 33. G; estágio 34. H; estágio 35. I; estágio 36. Barra $5 \mathrm{~mm}$.

Figura 28 Detalhes do desenvolvimento dos embriões de I. iguana iguana. A e B; estágio 29. C; estágio 30. D; estágio 31. E; estágio 32. Fn, fosseta nasal; fc, fissura coroide; pa, placóide auditivo; af, arcos faríngeos; ma, mandíbula. Barra: $2 \mathrm{~mm}$.

Figura 29 Embriões de I. iguana iguana. A; estágio 37. B; estágio 38. C; estágio 39. D; estágio 40. E; estágio 41. F; estágio 42. G; estágio 43. $\mathrm{H}$; estágio 44. I, recém eclodido. Barra $1 \mathrm{~cm}$

Figura 30 Sequência de desenvolvimento do membro torácico em embriões de I. iguana. Microscopia eletrônica de varredura do broto do membro nos estágios 28 (A), 29 (B) e 30 (C), onde é possível notar a formação e desenvolvimento da placa digital. Barra $300 \mu \mathrm{m}$. Fotografias nos estágios 31 (D), 32 (E), 33 (F), $34(\mathrm{G}), 36(\mathrm{H}), 38$ (I), $40(\mathrm{~J}), 43(\mathrm{~K})$ e 44 (L). Barra: $1 \mathrm{~mm}$

Figura 31 Sequência de desenvolvimento do membro pelvino em embriões de $I$. iguana. Microscopia eletrônica de varredura do broto do membro nos estágios 28 (A), 29 (B) e 30 (C). Em A é possível observar a presença da crista apical (seta) e em $\mathrm{C}$ o primórdio dos artelhos na superfície da placa digital (cabeça da seta). Barra $300 \mu \mathrm{m}$. Fotografias nos estágios 31 (D), 32 (E), 33 (F), 34 (G), 36 (H), 38 (I), 41 (J), 43 (K) e 44 (L). Barra: $1 \mathrm{~mm}$.

Figura 32 Detalhes da sequência de desenvolvimento do crânio em embriões de I. iguana iguana. A; estágio 37. B; estágio 38. C; estágio 39. D; estágio 44. E; estágio 37. F, G e I; estágio 40. H e J; estágio 41. K; estágio 42. L; estágio 44. os, ossículos da esclera; pa, pálpebra; pg, prega genital; do, dente do ovo; na, narina externa. Barra $3 \mathrm{~mm}$.

Figura 33 Sequência de desenvolvimento do crânio em embriões de I. iguana iguana. Vista lateral. A, estágio 36; B e C, estágio 37; D, estágio 38; E, estágio 39; F, estágio 40; G, estágio 41; H, estágio 42; I, estágio 44. An, angular; Ar, articular; Co, coronóide; De, dentário; Ept, epipterigóide; Es, esquamosal; Ex, exoccipital; Fr, frontal; Hi, hióide; $\mathrm{Ju}$, jugal; La, lacrimal; Ma, maxila; Na, nasal; Op, opstótico; Pa, parietal; Pfr, pré-frontal; Pl, palatino; Pm, pré-maxila; Po, pós-orbital; 
Pof, pós-frontal; Pt, pterigoide; Qu, quadrado; Sa, suprangular; So, supraoccipital; St, supratemporal. Barra 5mm.

Figura 34 Sequência de desenvolvimento do crânio em embriões de I. iguana iguana. Vista dorsal. A, estágio 37; B, estágio 38; C, estágio 39; D, estágio 40; E, estágio 41; F, estágio 42. Bo, basioccipital; Es, esquamosal; Ex, exoccipital; Fr, frontal; Ju, jugal; Na, nasal; Ob, orbitoesfenóide; Op, opstótico; Ot, otoccipital; $\mathrm{Pa}$, parietal; $\mathrm{Pb}$, parabasesfenóde; Pfr, pré-frontal; Pl, palatino; Pm, pré-maxila; Po, pós-orbital; Pof, pós-frontal; Pt, pterigoide; So, supraoccipital. Barra $5 \mathrm{~mm}$.

Figura 35 Sequência de desenvolvimento do crânio em embriões de I. iguana iguana. Vista ventral. A, estágio 36; B, estágio 38; C e D, estágio 39; E, estágio 41; F, estágio 43 (sem mandíbula). An, angular; Ar, articular; Bo, basioccipital; De, dentário; Ec, ectopterigóide; Ex, exoccipital; Hi, hióide; Ju, jugal; Ma, maxila; Or, orbitoesfenóide; Ot, otoccipital; $\mathrm{Pb}$, parabasesfenóide; Pfr, pré-frontal; Pl, palatino; Pm, pré-maxila; Pt, pterigoide; Sa, suprangular; Vo, vômer. Barra $6 \mathrm{~mm}$

Figura 36 Fotografias de detalhes do desenvolvimento do crânio em embriões de I. iguana iguana. A, estágio 39 evidenciando a topografia do osso pós-frontal. B, estágio 40 em vista lateral da região pós orbital. C e D, estágio 41. Presença da septomaxila ( $\mathrm{Sm})$ dentro da cavidade nasal. E, estágio 39 vista dorsal da parte rostral co crânio. Note que o prémaxila se ossifica por meio de dois centros distintos. Ep, epipterigóide; Es, esquamosal; Ex, exoccipital; La, lacrimal; Ma, maxila; na, nasal; Op, opstótico; $\mathrm{Pa}$, parietal; $\mathrm{Pf}$, pré-frontal; $\mathrm{Pl}$, palatino; Pm, pré-maxila; Po, pós-orbital; Pof, pós-frontal, Sm, septomaxila, St, supratemporal. Barra $5 \mathrm{~mm}$.

Figura 37 Figura 29: Sequência do desenvolvimento dos ossículos da esclera em embriões de I. iguana iguana. Vista lateral. A, estágio 28. Embora o olho esteja em avançado processo de formação, ainda não existe a presença de ossículos na esclera. B, estágio 37 e C, estágio 38. As cabeças das setas apontam áreas claras onde os ossículos da esclera estão presentes na superfície anterior do olho. em vista lateral da região pós orbital. D, estágio 35. Espécime clareado e corado com Alizarina e Azul de alcian. Neste estágio a formação dos elementos ossificados do olho não é observada pela coloração. E, estágio 37; F, estágio 38; $\mathrm{G}$, estágio 39; $\mathrm{H}$, estágio 41; I, estágio 44. Desenvolvimento dos ossículos da esclera em diferentes estágios........ 
Figura 38 Globos oculares de embriões de I. iguana iguana. As fotografias mostram, em vista anterior, o gradiente de coloração das placas que formam o anel escleral ossificado em iguana. A, estágio 36; $\mathrm{B}$, estágio 37; C, estágio 38; D, estágio 39; E, estágio 40; F, estágio 41; G, estágio 43; H, estágio 44. Barra 2mm.

Figura 39 Cortes do globo ocular de embriões de I. iguana iguana. A e B estágio 34. Em A, a área destacada evidencia a zona de condensação referente a formação dos ossículos na esclera do embrião (detalhe em B com aumento marcado pelas cabeças das setas). C, corte frontal do olho de iguana no estágio 35. As setas indicam três áreas em avançado processo condensação. $\mathrm{D}$, estágio $36 \mathrm{com}$ a clara presença de tecido mineralizado indicando o início do processo de ossificação. As setas indicam uma faixa de condensação abaixo do tecido ósseo em formação. E-G, estágio 37 nos aumentos 10x, 20x e 40x respectivamente. É possível observar a matriz mineral e células ósseas imersas na mesma em uma área relativamente bem delineada. $\mathrm{H}-\mathrm{K}$, estágio 40. Em H a fotogradia panorâmica do corte transversal do globo ocular permite a identificação dos ossículos da esclera (cabeças das setas) na posição em que ocupam nos espécimes. $\mathrm{O}$ aumento (20x) em I mostra a sobreposição das placas ósseas e a presença de tecido entre ambas $(*)$. No mesmo estágio, com aumento 40x pode-se observar a camada adjacente de tecido muscular na parte inferior do ossículo. K, estágio 43. Detalhe do ossículo da esclera em corte transversal. H.E. Barra $100 \mu \mathrm{m}$

Figura 40 Sequência de ossificação das vértebras cervicais em embriões de $I$. iguana iguana. A, estágio 37; B, estágio 40; C, estágio 42; D, estágio 43; E, estágio 44; $\mathrm{F}$, embrião de 1 dia pós eclosão. $\mathrm{O} *$ em $\mathrm{C}$ evidencia o contato do corpo vertebral $(\mathrm{Cv})$ e do arco vertebral (Av), ainda não fusionados neste estágio. Barra $5 \mathrm{~mm}$.

Figura 41 Sequência de ossificação das vértebras em embriões de I. iguana iguana. A e B estágio 36; C, estágio 37; D, estágio 40; E estágio 42; $\mathrm{F}$, estágio 43. Av, arco vertebral; $\mathrm{Cc}$, costela cervical; $\mathrm{Cd}$, costela dorsal; $\mathrm{Cv}$, centro vertebral. Barra $3 \mathrm{~mm}$.

Figura 42 Sequência de ossificação das vértebras dorsais em embriões de $I$. iguana iguana. A e B estágio 37; C e D, estágio 41; E e F, estágio 43; G e H estágio 39; I, estágio 41; J, estágio 44. Barra 7mm.

Figura 43 Sequência de ossificação das vértebras sacrais em embriões de $I$. iguana iguana. A estágio 38; B, estágio 39; C, estágio 40; D, estágio 42; E e F, estágio 44. Ac, arco vertebral; Cv, corpo vertebral; cs, 
Figura 44 Sequência de ossificação das vértebras caudais em embriões de $I$. iguana iguana. A-C, estágio 39; D-F e H, estágio 41; G e I, estágio 44. Ac, arco vertebral; $\mathrm{Cv}$, corpo vertebral; ph, processo hemal

Figura 45 Sequência de ossificação do esqueleto peitoral em embriões de $I$. iguana iguana. A, estágio 39; B, estágio 41; C, estágio 44. ce, cartilagem esternal; cl, clavícula; ic, interclavícula. Barra $3 \mathrm{~mm}$

Figura 46 Sequência de formação da cintura e membros torácicos em embriões de I. iguana iguana. A, estágio 35; B, estágio 37; C-E, estágio 38; F, estágio 40, G, estágio 43; H, estágio 44. Cl, clavícula; Co, coracóide; Es, escápula; Int, interclavícula; R, radio,; U, ulna; Um, úmero. Em G e H está presente um centro de ossificação secundário independente para a epífise do úmero (cabeça da seta). Barra $4 \mathrm{~mm}$.

Figura 47 Sequência de formação cartilagínea dos membros torácicos em embriões de I. iguana iguana. No estágio 28 (A) é difícil a identificação de estruturas, embora exista indícios do início do processo de condensação condrogênica, tornando evidente a presença do eixo primário pela estrutura visível do dígito IV. Estágio 29 (B) com clara presença do eixo primário, seguindo o desenvolvimento pela formação do arco digital (C) e avanço do processo ontogênico nos estágios 31 (D) e 32 (E e F). No estágio 32 o embrião corado apresenta 8 condensações (G). O pisiforme é um elemento conspícuo a partir do estágio 33 (I). J apresenta a morfologia completa do carpo cartilagíneo de I. iguana iguana no estágio 38. U, úmero; R, rádio; Ul, ulna; I, II, III, IV, V, dígitos; DcIII, distal do carpo III; DcIV, distal do carpo IV; DcII, distal do carpo II, DcV; distal do carpo V; c, central; i, intermédio; mc, metacarpo; pi, pisiforme; u, ulnar; r, radial. Clareamento com KOH e coloração com Alcian blue. Barra $1 \mathrm{~mm} . . . . . .$.

Figura 48 Cortes da sequência de formação dos elementos do autopodio dos membros torácicos em embriões de I. iguana iguana. Vista palmar panorâmica do estágio 35 (A). Estão presentes todos os dígitos. Os elementos distais II a V são conspícuos na base do respectivo metacarpo. No detalhe a direita é possível visualizar o primórdio do distal do carpo I na base do metacarpo I, embora durante a ontogenia o referido elemento não se desenvolva por completo (estágio 38 [D] cabeça da seta). Radial e ulnar estão evidenciados na extremidade distal do radio e ulna, respectivamente. O elemento intermédio apresenta-se conspícuo e, no detalhe, é possível reconhecer a forma inconspícua do central surgindo como um elemento independente. No 
estágio 34 (B) a formação do eixo primário está adiantada, sendo possível a definição dos elementos ulnar e distal do carpo IV. Autopódio no estágio 35 (C) evidenciando a relação entre o radio e o radial (cabeça da seta). Estágio 38 (D), sendo possível a visualização de quatro elementos distais e seus respectivos metacarpos. Nesta imagem o metacarpo I exibe uma área proximal correspondente ao distal do carpo I (cabeça da seta), fundido em estrutura única visto que este não segmenta-se da cartilagem do metacarpo. Em E, durante o estágio 42, alguns elementos do carpo (DcII, DcIII, DcIV e u) apresentam hipertrofia da cartilagem, evidenciando o início do processo de ossificação. Segmentação (seta) da cartilagem da falange 1 a partir do metacarpo no estágio $34(\mathrm{~F})$ e $35(\mathrm{G})$. Corte transversal (H) e longitudinal (I) de um metacarpo no estágio 37. O anel pericondral exibe sinais conspícuos de ossificação, restritos a porção média do elemento (cabeça da seta [I]). A porção interna apresenta uma grande quantidade de cartilagem hipertrófica. $\mathrm{R}$, rádio; $\mathrm{U}$, ulna; I, II, III, IV e V, dígitos; DcI, DcII, DcIII, DcIV e DcV, distais do carpo, u, ulnar; r, radial; i, intermédio; c, central. Coloração H.E.........

Figura 49 Sequência de ossificação da mão em embriões de I. iguana iguana. No estágio 33 (A) todos os elementos cartilagíneos estão formados, sendo possível observar o início do processo de ossificação no metacarpo III e de forma inconspícua no metacarpo IV. As falanges ungueais apresentam condensação do esbouço cartilagíneo (cabeça da seta). No início do estágio 38 (B) os metacarpos II, III e IV estão em processo de ossificação inicial e algumas falanges 1. A ossificação das falanges ocorre no decorrer do estágio 38 (C) e 39 (D). As falanges ungueais apresentam ossificação no estágio 40 (E). Todos os elementos dos dígitos iniciaram sua ossificação até o estágio 42 (F). Início da ossificação do autopódio, estágio 43 (G) e aspecto no final do período de incubação, no estágio $44(\mathrm{H})$. R, rádio; U, ulna; I, II, III, IV e V, dígitos; DcII, DcIII, DcIV e DcV, distal do carpo; u, ulnar, r, radial; c, central; i, intermédio; pi, pisiforme; Mc, metacarpos; F, falanges; Fu, falange ungueal. Clareamento com $\mathrm{KOH}$ e coloração com Alizarina red S e Alcian blue. Barra 1mm.

Figura 50 Sequência de formação cartilagínea dos membros pelvinos em embriões de I. iguana iguana. No estágio 28 (A) é possível visualizar o processo de condensação condrogênica avançado, apresentando o primórdio dos artelhos IV, III e II. Nos estágios 29 (B) e 30 (C) as presenças do eixo primário e do arco digital marcam o avanço do processo ontogênico. No estágio 31 (D e detalhe E) a placa digital está bem desenvolvida. Condensações no autopódio definem a formação de alguns elementos como os distais III e IV, fibular ainda 
individualizado e a formação do astragalus pela fusão com o elemento intermédio (E). No estágio 39 (F) é possível observar que não ocorre a separação dos distais I, II e V e as falanges segmentaram da cartilagem do metatarso (cabeça da seta). G (detalhe I) apresenta o arcabouço cartilagíneo do pé durante o início do processo de ossificação no estágio 40. H, estágio 38; J. Estágio 41. as, astragalus; F, fíbula; T, tíbia; IV, III e II, artelhos; DtIV, distal do tarso IV; DtIII, distal do tarso III; f, fibular; in, intermédio; Mt, metatarso. Clareamento com KOH e coloração com Alcian blue. Barra $1 \mathrm{~mm} . . . . . .$.

Figura 51 Autopodio dos membros pelvinos em embriões de I. iguana iguana. Cortes em diferentes períodos de desenvolvimento durante o estágio 38 (A, B e C). Os únicos elementos distais presentes estão destacados, sendo o DtIII e DtIV, contatando seus respectivos metatarsos. Em A, o nível dorsal do corte permite a visualização de duas estruturas distintas para o fibular e o intermédio (formando o astragalus), estando estes em B como um grande e único elemento denominado proximal do tarso. Ainda podemos notar a não segmentação dos elementos distais I e II a partir da extremidade proximal da cartilagem do metatarso (cabeça da seta [B]). A relação entre o metatarso IV e o DtIV (cabeça da seta) é visualizada em C. Estas estruturas estão diferenciadas, porém uma extensa área de tecido compartilhado é conspícua. No estágio 43 (D) a estrutura da matriz cartilagínea se altera, sendo possível notar o primórdio de dois centros de ossificação distintos para o elemento proximal do tarso, um para o fibular e outro para o astragalus. as, astragalus; DtIII, DtIV, distal do tarso; f, fibular; in, intermédio; T, tíbia; MtI, MtII, MtIV, metatarso; Prt, proximal do tarso. Coloração H.E

Figura 52 Sequência de ossificação do pé em embriões de I. iguana iguana. No estágio 38 (A) todos os elementos cartilagíneos estão formados, sendo possível observar o início do processo de ossificação nos metatarsos II, III e IV. Durante o estágio 38 (B) e 39 (C) a ossificação nas falanges tem inicia. As falanges ungueais (cabeça da seta) não apresentam ossificação no estágio 39 (D). O metacarpo V evidencia uma inconspícua retenção de corante no estágio 40 (E). O início da ossificação do autopodio ocorre no estágio 43 (F e G) onde pode ser observado a presença de dois centros de ossificação distintos para este elemento. No estágio $44(\mathrm{H})$ o DtVI e o DtIII apresentam centros de ossificação marcados. as, astragalus; T, tíbia; F, fíbula; I, II, III, IV e V, artelhos; Mt, metatarso; F1, falanges; f, fibular; Prt, proximal do tarso. Clareamento com $\mathrm{KOH}$ e coloração com Alizarina red S e Alcian blue. Barra $1 \mathrm{~mm}$. 
Figura 53 Sequência de ossificação do cíngulo e membro pelvino em embriões de I. iguana iguana. A e B, estágio 38. C, estágio 39. D-F, estágio 40. $\mathrm{G}$ e H, estágio 42. I, estágio 43 (cabeça da seta indicando o processo de ossificação secundário na epífise do osso). F, fêmur; Ti, tíbia; Fi, fíbula; il, ilíaco; is, ísquio; pu, púbis. Barra $2 \mathrm{~mm}$.

Tabela I Relação de dias de desenvolvimento in ovo por estágio, número de embriões analisados e características chaves de cada estágio.

Tabela II Comparativo de características de desenvolvimento entre espécies de lagarto. (a) presente estudo; (b) Lemus et al., 1981; (c) Sanger et al., 2008; (d) Gregorovicova et al., 2012; (e) Noro et al., 2009; (f) Wise et al., 2009. ST, estágio baseado em Dufaure e Hubert (1961), SS, estágio descrito por Sanger et al. (2008); * sem comentários no artigo; ** dado obtido da imagem; $\mathrm{n}$, não visualizado; $\mathrm{p}$, pelvino; $\mathrm{t}$, torácico; dpo, dias pos-oviposição

Tabela III Resumo da sequência de ossificação do esqueleto axial de I. iguana iguana....

Tabela IV Resumo da sequência de ossificação dos elementos da cintura e membros torácicos de I. iguana iguana.

Tabela V Resumo da sequência de ossificação dos elementos da cintura e membros pelvinos de I. iguana iguana. 
RESUMO: Investigações que abordam a ontogenia dos vertebrados objetivam padronizar a descrição de uma sequência de desenvolvimento, subsidiando as discussões acerca da evolução dos animais. Objetivando esclarecer o padrão da ontogenia de Iguana iguana iguana, embriões incubados artificialmente à temperatura constante de $30^{\circ} \mathrm{C}\left( \pm 0,1^{\circ} \mathrm{C}\right)$ foram coletados diariamente (dia 1-10) e em intervalos de dois dias (dia 10 até a eclosão), fixados em solução de formol 10\% e depois mantidos em álcool 70\%, totalizando 142 espécimes. A amostra foi avaliada para a determinação das características morfológicas e posteriormente clareada com KOH e corada com vermelho de Alizarina e azul de Alcian. Alguns espécimes foram submetidos a microscopia eletrônica de varredura e outros a protocolo usual de histologia. Confeccionamos uma tabela de desenvolvimento normal para embriões de $I$. iguana iguana. Relatamos 17 estágios (28 a 44, haja vista que o desenvolvimento inicial estágios 1 a 27 - ocorre antes da oviposição) com base em características de desenvolvimento externo como arcos faríngeos, vesículas encefálicas, arcabouço crânio-facial, membros, escamas, pigmentação, dentre outros. Para a descrição do esqueleto do animal adulto, utilizamos dois espécimes que vieram a óbito por causas naturais. $\mathrm{O}$ esqueleto foi preparado seguindo métodos usuais e posteriormente descrito. Crânio, ossículos da esclera, aparelho hióide, vértebras e membros apresentam estrutura similar a dos demais lagartos, embora com sutis variações. Adicionalmente averiguamos a condrogênese e a ossificação dos membros torácicos e pelvinos. A condensação dos elementos proximais dos membros seguiu o padrão descrito para Tetrapoda, com a formação do eixo primário fêmur/úmero, rádio/fíbula e ulna/tíbia e, a partir do rádio/fíbula surge o radial/fibular e, posteriormente o elemento distal IV, o dígito/artelho IV, continuando no sentido pré-pós axial e formando o arco digital. No membro torácico a formação dos elementos distais foi observada para todos os cinco dígitos. $\mathrm{O}$ dcI permaneceu fundido ao mcI. I. iguana iguana possui um elemento central e outro intermédio no carpo adulto. Estes se formaram por meio de uma condensação independente do arco digital e se ossificaram no período pós eclosão. A condrogênese do membro pelvino foi similar aos relatos para outros lagartos. A presença de dois elementos distais do tarso é compartilhada pela maioria dos répteis. Não foi possível averiguar com clareza a origem do astragalus. Observamos uma intensa área de condensação na região central do tarso que originou o referido elemento, porém a presença de estruturas individualizadas não foi confirmada. Astragalus e fibular se fundiram para formar o proximal do tarso que iniciou sua ossificação no período embrionário (estágio 42) por meio de dois centros de ossificação distintos. Os elementos distais III e IV foram os únicos a se segmentar, os demais permaneceram fundidos a cartilagem do metatarso. $\mathrm{O}$ dígito $\mathrm{V}$ apresentou desenvolvimento 
tardio em todos os embriões. A ossificação dos membros e vértebras ocorreu como descrito para os demais répteis. O gradiente de ossificação nas vértebras foi crânio-caudal com a formação de centros de ossificação independentes para o centro vertebral, arco vertebral e costelas. No cíngulo torácico a escápula se ossificou primeiro seguido pelo coracóide. O ilíaco foi a primeira estrutura a se ossificar na pelve, seguido pelo púbis e ísquio. O período de incubação foi de aproximadamente dois meses em ambiente controlado. Com o uso de metodologia similar foi possível aproximar os resultados aos dados obtidos para outros lagartos, averiguando muitas similaridades, o que confirma a característica conservativa do desenvolvimento embrionário do grupo.

Palavras chave: Autopódio, iguana verde, lagartos, ossificação, squamata. 
ABSTRACT: Investigations addressing the ontogeny of vertebrates aim to standardize the description of a developmental sequence, supporting discussions about the animals evolution. Aiming to clarify the pattern of the ontogeny of Iguana iguana iguana, embryos artificially incubated at a constant temperature of $30^{\circ} \mathrm{C}\left( \pm 0.1^{\circ} \mathrm{C}\right)$ were collected daily (days 1-10) and at intervals of two days (day 10 to hatching), fixed in formalin solution $10 \%$ and then kept in alcohol $70 \%$ totaling 142 specimens. The sample was evaluated to determinate morphological features and was cleared with $\mathrm{KOH}$ and stained with Alizarin red and Alcian blue. Some specimens were subjected to scanning electron microscopy and the others through usual histology protocol. A normal development table was made with 17 stages ( 28 to 44, the initial development - stages 1 to 27 - occurs prior to oviposition), based on external characteristics such pharyngeal archs, brain vesicles, craniofacial features, limbs, scales, pigmentation, among others. For the description of the adult skeleton, we used two specimens that died of natural causes. The skeleton was prepared following standard methods and subsequently described. Skull, scleral ossicles, hyoid, vertebrae and limbs have similar structure to that of other lizards, albeit with subtle variations. Additionally we ascertained the chondrogenesis and the ossification of forelimb and hindlimb. The condensation of the proximal elements of these followed the described pattern of Tetrapoda: formation of the primary axis femur/humerus, radius/ulna and fibula/tíbia, from the radius/fibula comes the radiale/fibulare, later the distal element IV, the digit/toe IV, continuing the pre-post axial direction and forming the digital arc. In the forelimb the formation of the distal elements was observed for all five digits. The dcI remained fused to the mcI. I. iguana iguana has one central and intermedium element of carpus. These were formed by an independent condensing apart from digital arch and its ossification occurs in post hatching. The chondrogenesis of hindlimb was similar to those reported for other lizards. The presence of two distal elements of the tarsus is shared with most reptiles. It was not possible to ascertain clearly the astragalus origin. We observed a clouded condensation area in the central region of the tarsus that originated this element, but the presence of individual structures was not confirmed. Astragalus and fibular merged to form the proximal tarsal, which started to ossificate in the embryonic period (stage 42) by two individual ossification centers. The distal elements III and IV were the only ones differentiated, the others remained fused with metatarsal cartilage. The digit V presented late development in all embryos. The ossification of the limbs and vertebrae occurred as described for other reptiles. The ossification gradient in the vertebrae was cranio-caudal with formation of independent ossification centers to vetebrae center, vertebrae arch and ribs. In the thoracic girdle, the scapula ossified first followed by coracoid. The ilium was the first to ossify in the 
pelvis, followed by pubis and isquium. The incubation period was approximately two months, in a controlled environment. Using similar methodology, it was possible to approximate these results with data of other lizards, verifying many similarities, what confirmed the conservative pattern of embryonic development for reptiles.

Keywords Autopodium, green iguana, lizards, ossification, squamata. 


\section{O1 INTRODUÇÃO}

Compreender as interações entre os indivíduos é de insigne importância para as investigações em biodiversidade (Pagel, 1997). Este entendimento depende do conhecimento de características como morfologia, fisiologia, genética, ecologia e etologia, dentre outros, sendo utilizadas como dados consistentes que possibilitam esclarecer as mais diversas características dos seres vivos (Grazziotin e Fernandes, 2007).

O conhecimento do desenvolvimento anatômico auxilia a compreensão das tendências funcionais e das preferências ambientais em diferentes estágios de desenvolvimento, o que pode ser usado para desvendar grande parte dos aspectos da biologia evolutiva e na reconstrução de filogenias (Shubin e Alberch, 1986, Mabee et al., 2000; Gilbert et al., 2001). Estudos sobre ontogenia têm sido importantes para esclarecer características da estrutura básica dos organismos. Os répteis, por exemplo, apresentam componentes esqueléticos especializados (Lee, 1996; Gilbert et al., 2001; Li et al., 2008) e suas modificações podem ser entendidas por meio do estudo ontogênico relacionado com o padrão evolutivo (Hildebrand e Goslow, 2006).

Investigações que abordam o desenvolvimento das espécies têm se mostrado uma ferramenta imprescindível para o entendimento das relações biológicas, evolutivas e, mais recentemente, do caráter molecular dos grupos de interesse (Karaku et al., 2005; Ohya et al., 2005; Boughner et al., 2007; Noro et al., 2009). Durante a última década o valor de trabalhos que levantaram caracteres para pesquisas em filogenia e padrões embriológicos aumentou, evidenciando-se como ferramentas de suporte as investigações filogenéticas com ênfase em métodos de máxima parcimônia (Smith, 1997; Jeffery et al., 2002, 2005; Harrison; Larsson, 2008; Weneburg, 2009). Harrison e Larsson (2008) ainda citam a existência de novas ferramentas para biologia comparada do desenvolvimento como uma das razões para essa valorização. Tais fatores tornam a documentação da embriologia importante, porém, particularmente um desafio para a biologia (Müller e Hassel, 2003; Gilbert, 2006; Wolpert et al., 2007).

\section{Répteis}

Os répteis representam aproximadamente 6400 espécies, que segundo uma revisão taxonômica baseada na filogenia, se dividem em quatro grupos, Testudines (tartarugas, cágados e jabutis), Lepidosauria (lagartos, serpentes, anfisbenias e tuatara), Crocodylia 
(crocodilos, jacarés e gaviais) e Aves, cada um destes com características aparentes sendo o primeiro grupo a habitar o ambiente terrestre com êxito (Rieppel e Reisz, 1999; Pough et al., 2003; Storer et al., 2005).

Historicamente este grupo foi alvo de estudo de vários autores que buscaram investigar os mais diversos aspectos da etologia, fisiologia, morfologia, ontogenia. Alguns grupos, entretanto, continuam ainda sem a devida documentação de seu desenvolvimento.

Os répteis Squamata estão dentre as mais diversas radiações dos vertebrados terrestres. Estes incluem quase dez mil espécies conhecidas de lagartos, anfisbênias e serpentes dispersas por biomas variados pelo planeta. São ecologicamente e morfologicamente distintos sobretudo ecologica, fisiologica, e etologicamente, o que reflete na grande capacidade de sobrevivência do grupo (Zug et al., 2001).

Existe um forte suporte a monofilia em todos os fósseis e viventes de Tetrapoda (Gauthier et al., 1988; Panchen e Smithson, 1988; Cannatella e Hillis, 1993; Hedges e Maxson, 1993; Ahlberg e Milner, 1994; Carrol, 1995; Coates, 1996; Wagner e Chiu 2001). Esse monofiletismo é sustentado por aproximadamente 70 características derivadas, como ausência dos dentes vomerianos, ausência de contato entre os ossos pterigóide e vômer, fusão precoce dos centros de ossificação do exoccipital com opistótico (formando o otoccipital), redução dos ossos dos tarsos (Zug, 1993). Estes et al. (1988) adicionam a fusão ontogenética dos parietais como uma sinapomorfia do grupo.

Embora muitos pesquisadores tenham se ocupado com a classificação do grupo (Gaffney e Meylan, 1988; Rieppel, 1993a; Gilbert et al., 2001; Klembara 2004, 2005; Boughner et al., 2007; Buchtová et al., 2007; Li et al., 2008; Scheyer et al., 2008; Bona e Alcalde, 2009; Werneburg e Sánchez-Villagra, 2009) a completa elucidação de sua filogenia é ainda alvo de muitas discussões.

Hipóteses acerca da filogenia do grupo tem sofrido mudanças radicais nos ultimo anos, principalmente quando comparamos dados morfológicos e moleculares. Romer (1956) dividiu os Squamata em dois grupos: Lacertilia (lagartos e anfisbenas) e Ophidia. Gans (1978) posicionou as anfisbenas em um grupo particular (Amphisbaenia). Segundo Estes et al. (1988), o grupo Squamata seria monofilético.

Além dos táxons supracitados, outros três fazem parte de Squamata, sendo eles Amphisbaenia, Dibamidae e Serpentes (Estes e Pregill, 1988). Estes três grupos são compostos por espécies de corpo alongado e ápodes, exceção sendo o gênero Bipes. Este gênero pertence ao grupo anfisbenas, composto pelas famílias Trogonophidae, Bipedae, Amphisbaenidae e Rhineuridae (Kearney, 2003). 
O clado Lepidosauria inclui os Rhynchocephalia e os Squamata. O primeiro grupo está representado atualmente por apenas uma família (Sphenodontidae), composta pelo gênero Sphenodon que contém duas espécies (Zug, 1993). Por outro lado, os Squamata representa um grupo de espécies cujo monofiletismo é sustentado por sinapomorfias como a presença de fenda cloacal transversal, hemipênis, fusão do pré-maxila (Estes e Pregill, 1988; Pough et al., 2003). Este grupo é subdividido em dois grandes clados: Iguania e Scleroglossa (Estes e Pregill, 1988), embora dados moleculares não sustentem esta divisão (Townsed et al., 2004; Vidal e Hedges 2005).

Grande parte dos autores consideram Iguania como sendo composta por duas linhagens distintas, sendo elas: a linhagem acrodonte e outra composta pelas famílias que formavam a antiga família Iguanidae (Camp, 1923; Estes et al., 1988; Lee, 1998, 2000; Caldwell, 1999; Caprette et al., 2004). Filogenias moleculares recentes também sustentam o monofiletismo destas duas linhagens (Macey et al., 2000; Schulte et al., 2003).

A antiga família Iguanidae foi dividida em diversas famílias (Frost e Etheridge, 1989), muitas das quais são sustentadas por dados moleculares (Schulte et al., 2003; Townsend et al., 2004). Atualmente são reconhecidas as Famílias Corytophanidae, Crotaphythidae, Hoplocercidae, Iguanidae, Polychrotidae, Leiosauridae, Opluride, Phrynosomatidae, Tropiduridae, Leiocephalidae e Liolaemidae (Frost et al., 2001). As relações entre algumas destas famílias não se encontram bem resolvidas (Titus e Frost, 1996; Macey et al., 1997; Schulte et al., 1998; Frost et al. 2001).

Dados morfológicos recentes sustentam a divisão basal entre Iguania e Scleroglossa. Em contraste, dados moleculares apresentam uma nova estrutura na filogenia do grupo, colocando por exemplo, Iguania e serpentes no mesmo grupo e Scleroglossa e Anguimorpha. Atualmente, com base em dados moleculares, foi prosposto que o clado Toxicofera inclui Iguania com Serpentes e Anguimorpha dentro de Scleroglossa (Fig. 1). Eles encontram um forte suporte ao monofilestismo de Iguania, principalmente com dados nucleares (Pyron et al., 2013).

A espécie Iguana iguana iguana pertence a familia Iguanidae que do latim significa lagarto. São popularmente conhecidos em muitas regiões do Brasil como lagartos verdes (Ávila-Pires, 1995). Com distribuição geográfica nas áreas tropicais e subtropicais da América, pode ocorrer desde México até o Paraguai. No Brasil são encontrados em todos os biomas. Estes lagartos podem atingir até 1,80 $\mathrm{m}$ de comprimento e pesar até 6 quilos quando adultos. 
Apresentam como características marcantes a crista dorsal proeminente, uma grande e arredondada escama abaixo dos tímpanos e uma prega gular bem desenvolvida. Sua cor varia desde um verde marcante, principalmente nos indivíduos jovens até o marrom em espécimes mais velhos. Durante o dia podem ser observados indivíduos em copas de árvores, no solo ou próximo a cursos d'água.

Sua alimentação é bastante diversificada, podendo se alimentar de insetos, folhas, brotos, flores e frutos. Quando o animal sente algum tipo de ameaça, pode reagir desferindo sua longa cauda como um movimento chicoteante contra o predador e até mordidas como uma forma de defesa (Burghardt e Rand, 1982).

Se reproduzem anualmente, no período entre outubro a abril. Sua maturidade sexual é atingida após o segundo ou terceiro ano de vida. As fêmeas normalmente apresentam coloração mais clara, com a crista-dorsal curta e prega gular menos desenvolvida. Os machos defendem seus territórios durante o período reprodutivo utilizando principalmente sua cauda como estratégia de proteção. Como atrativos sexuais estes animais exercem movimentos com a cabeça e tronco, além de exibição da prega gular (Estes e Price, 1973).
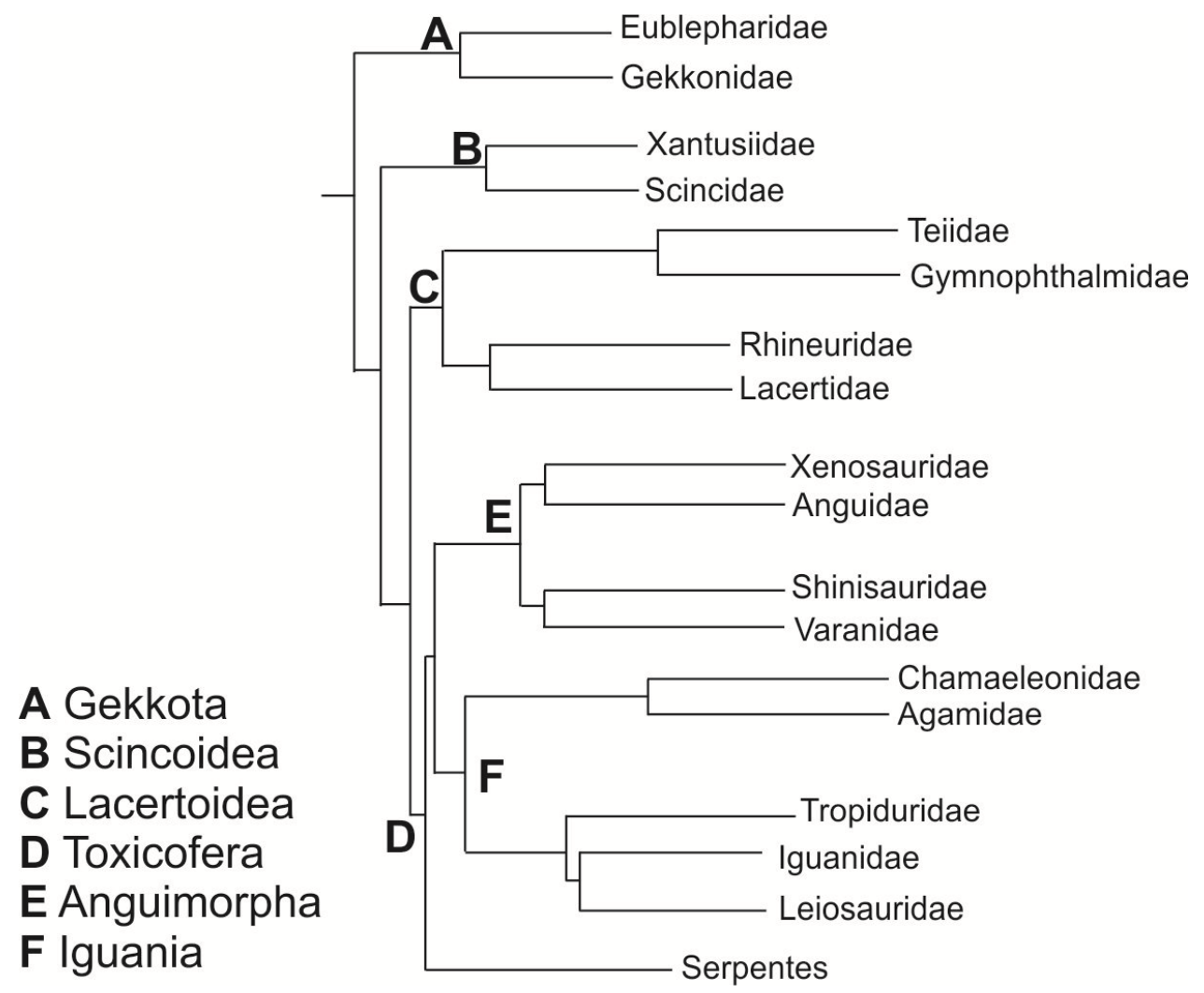

Figura 1: Representação da filogenia para Squamata baseada em dados moleculares. Adaptado: Pyron et al., 2013. 


\section{Esqueleto}

Nos vertebrados, o esqueleto representa um aparato importante que fornece subsidio para investigações de caráter morfológico, haja vista que a mineralização permite a manutenção das características desde sistema, o que viabiliza a especulação sobre as relações entre os diferentes seres viventes ou não (Buscalion et al., 1997). A variação deste componente reflete a plasticidade do mesmo para responder aos diferentes habitats dos animais, e fornecem informações importantes a respeito do modo de vida animal, como postura, porte, tipo de locomoção, alimentação, entre outras (Shubin et al., 1997; Kardong, 2010).

O esqueleto dos animais é anatomicamente dividido em crânio, coluna vertebral, costelas e o esqueleto apendicular, formado pelos ossos das cinturas peitoral e pelvina e pelos ossos dos membros torácicos e pelvinos (Rieppel, 1993b). Trata-se de um arcabouço de ossos e cartilagens articulados, com a função de oferecer aos músculos alavancas para os movimentos do corpo, além de suportar os tecidos envolventes, proteger órgãos e armazenar íons que o organismo retira quando necessário (Hildebrand e Goslow, 2006; Mackie et al., 2008).

Este elaborado conjunto de estuturas é composto basicamente por cartilagem e tecido ósseo (Hua e Buffrenil, 1996, White et al., 2003; Hildebrand e Goslow, 2006), que normalmente reflete as necessidades e o modo de vida dos animais. Entretanto, a despeito desta diversidade, eles apresentam algumas características embrionárias comuns e preservam um padrão que possibilita o entendimento da filogenia dos tetrápodes (Withers, 1992; Coates, 1994; Blob, 2000). O tecido é originário de células mesenquimais distintas. Células da crista neural formam o esqueleto craniofacial, o mesoderma paraxial deriva o esqueleto axial, e as células do mesoderma lateral formam os membros (Fig. 2) (DeLise et al., 2000; Olsen et al., 2000; Kawakami et al., 2006).

A osteogênese é o processo pelo qual o tecido ósseo se forma e desenvolve. Esse processo começa no embrião, mas pode se estender ocasionando mudanças ainda após o nascimento do individuo. A formação do osso durante o desenvolvimento embrionário pode ocorrer basicamente por duas maneiras: ossificação endocondral e ossificação intramembranosa. O osso formado por qualquer destes dois processos é idêntico histologicamente (Wagner e Karsenty, 2001).

No início do desenvolvimento as células mesenquimais condensam-se e formam os moldes do esqueleto. Estas condensações se diferenciam em condroblastos e formam o 
primeiro esboço cartilagíneo onde uma sequência de modificações regulares assinala o aparecimento de centros de ossificação (Olsen et al., 2000; Mackie et al., 2008). Os moldes de cartilagem sofrem o processo de mineralização que pode ocorrer na região média da diáfise, por meio do processo pericondral ou continuamente na estrutura da cartilagem que substituída gradativamente por osso (Inada et al., 2004).

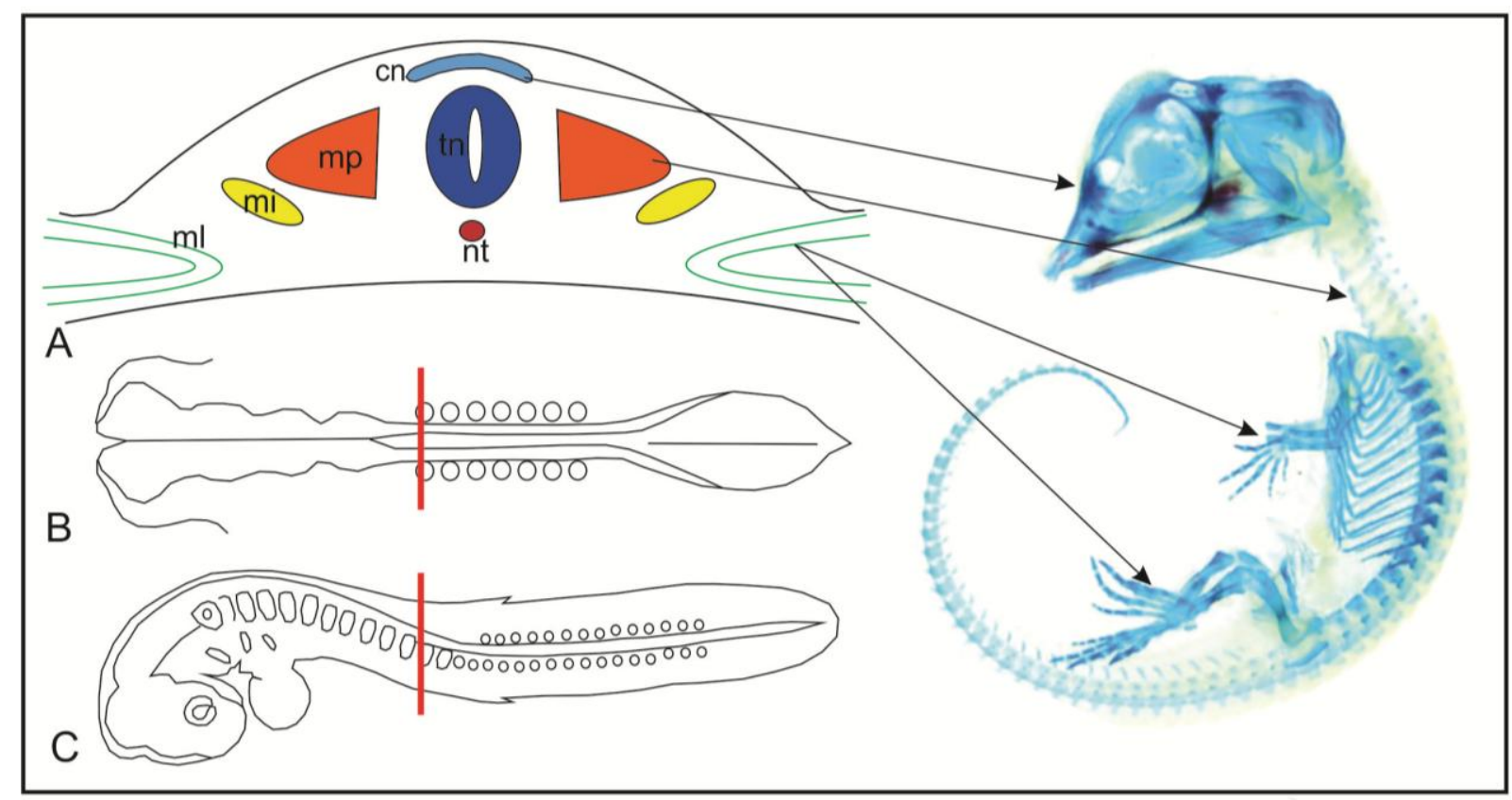

Figura 2: Representação esquemática das estruturas de origem embrionária do tecido ósseo. A, corte transversal do embrião evidenciando a topografia das estruturas do tubo neural (tn), mesoderma paraxial (mp), mesoderma intermediário (mi), mesoderma lateral (ml), crista neural (cn) e notocorda (nt). B, esquema em vista dorsal do embrião. C, esquema em vista lateral do embrião. As setas indicam as estruturas do esqueleto adulto formadas pelas respectivas estruturas no embrião. Adaptado: Gilbert, 2006. Embrião de Melanoshucus niger (Vieira, 2011).

Alguns componentes do esqueleto, principalmente no crânio, passam pelo processo de ossificação intramembranosa. Não existe neste processo a formação de um molde cartilagíneo. A mineralização ocorre diretamente na membrana conjuntiva vascularizada. Diversos centros de ossificação surgem na extensão da membrana e a substituem por tecido ósseo (Olsen et al., 2000; Scheyer e Sander, 2004).

Todos os vertebrados passam por fases semelhantes no desenvolvimento embriológico de suas estruturas. Este processo de desenvolvimento é relativamente constante segundo suas relações morfológicas dentre os animais (Bellais e Kamal, 1981). Após descritos os padrões e 
sequências da osteogênese estas informações são importantes ferramentas filogenéticas (Maisano, 2002b).

No grupo dos répteis o componente esquelético mais informativo é sem dúvida o crânio (Romer, 1956). Neste grupo ele inclui ossos dérmicos, de desenvolvimento endocondral e estruturas cartilagíneas. Os representantes deste grupo apresentam o neurocrânio bem ossificado com côndilo occipital único e elementos variados na composição de seu dermatocrânio, sendo o crânio dos Squamata aquele que sofreu as maiores modificações.

Embora o crânio dos vertebrados apresente uma grande variedade na arquitetura, função e padrões de crescimento, estes também possuem um alto grau de conservação nos mecanismos de desenvolvimento (Francis-West et al., 1998; Hall 1999). Em contrapartida, existem demandas funcionais as quais a anatomia destes organismos necessita se adaptar, refletindo no padrão de desenvolvimento das estruturas (Adriens e Verraes, 1998).

No geral, os padrões esqueléticos dos membros dos tetrápodes derivaram do padrão primitivo por perdas e fusões de elementos, que podem ser constatadas por meio de estudos da embriologia (Romer, 1956).

O desenvolvimento embrionário é arquitetado a partir de complexos padrões de expressão de genes organizados espaço-temporalmente, que regem a construção do organismo, e que são extremamente conservados entre os grupos (Richardson et al., 1999; Carrol et al., 2000). Variações nestes padrões são, na maioria das vezes, os mecanismos responsáveis pela diversidade fenotípica (Dover, 2000).

Uma das caracteristicas do grupo dos répteis é a presença de elementos ossificados na região da sclera (Fig. 3). Em aves, lagartos e testudines as papilas esclerais de origem da crista neural orientam a formação de pequenas placas ossificadas que se organizam na forma de um anel circular na região anterior da córnea (Coulombre et al., 1962; Andrews, 1996; Franz-Odendaal, 2005, 2008; Franz-Odendaal e Vickaryous, 2006).

O número desses ossículos pode variar dentre as espécies ou até mesmo entre os indivíduos. Sua sequência do desenvolvimento é altamente conservada, porém exibe certas variações na série de ossículos de cada grupo. É consenso que sua ossificação ocorre de maneira intramembranosa em répteis (Hall e Miyake, 1992; Franz-Odendaal, 2005, 2008).

A função destes elementos não é totalmente esclarecida. É reportado que este conjunto de placas fornece apoio e proteção dos olhos bem como serve para fixação e suporte para os músculos ciliares, na região anterior da córnea (Lemmrich, 1931). Lindley et al. (1988) sugerem que a abertura do anel pode facilitar a visão binocular dos animais e portanto, melhorar a acuidade visual. 


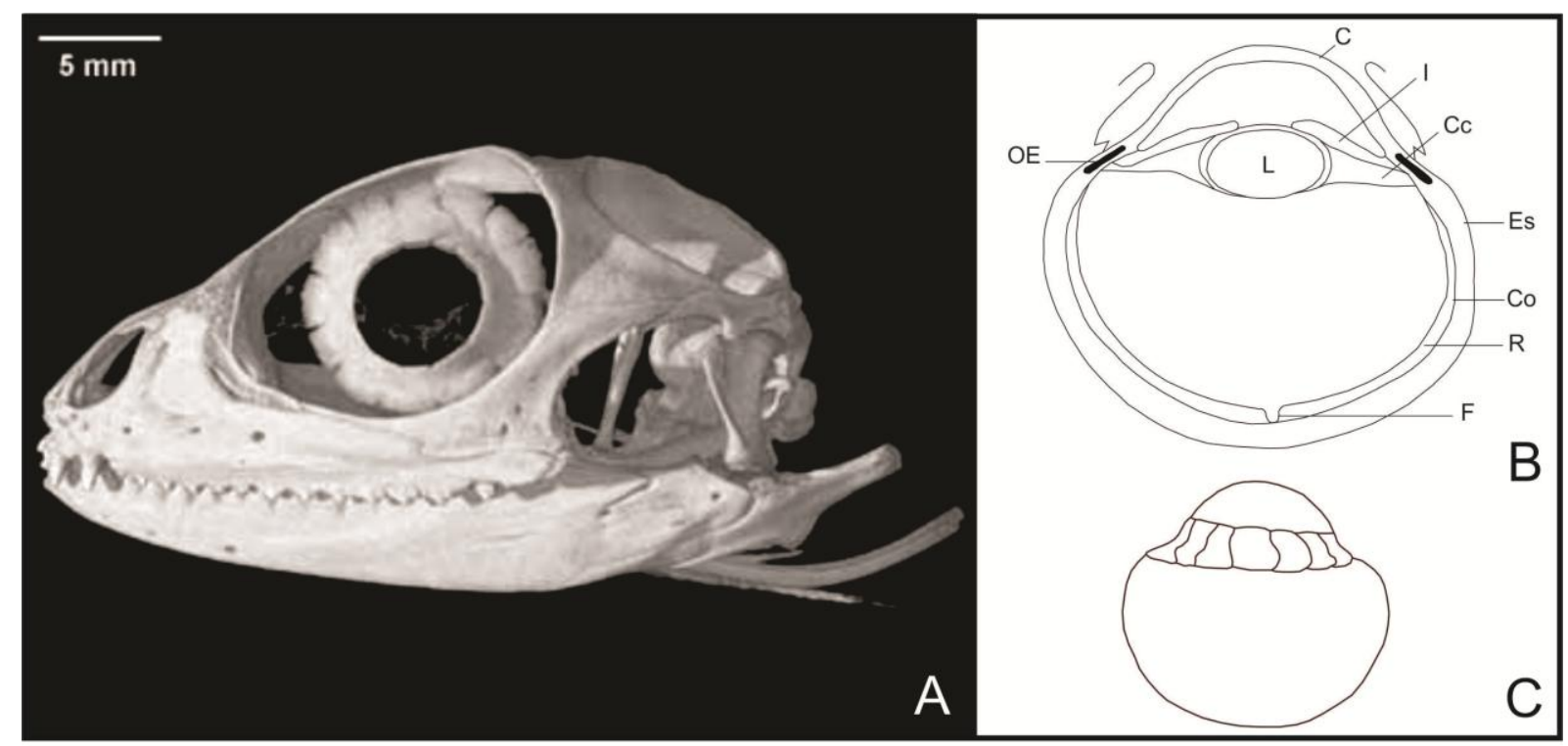

Figura 3: A, Reconstrução tridimensional do crânio adulto de Physianathus cocincinus. Maisano, 2015 (Disponível em: digimorph.org). Representação esquemética do globo ocular de répteis (C) em corte transversal (B). C, córnea; Cc, corpo ciliar; Co, coróide; Es, esclera; F, fovea; I, iris; L, lente; OE, ossículos da esclera; R, retina.

A presença de apêndices pares é a marca do plano corporal dos Tetrapoda. Nos últimos anos uma grandiosidade de estudos tem se dedicado ao foco evolutivo, morfológico e desenvolvimento deste segmento (Hall, 2007). Estes estudos viabilizam a sumarização de informações a partir de sua analise, embora muitas questões acerca de sua evolução, desenvolvimento e diversidade morfológica ainda permaneçam nebulosos (Shubin 2002; Shubin et al., 2009; Zeller et al., 2009; Woltering e Duboule 2010; Fröbisch e Shubin, 2011).

Com alto grau de diversidade, os membros dos Tetrapodas são historicamente correlacionados à aspectos locomotores e de vida de cada espécie. Este segmento, juntamente com o crânio, são as melhores ferramentas para a investigação de desenvolvimento, pois exibem uma sequência temporal de eventos de formação bem definida (Bininda-Emonds et al., 2007).

O tempo de desenvolvimento é bastante instável na evolução mas o padrão cronológico é muito forte filogeneticamente. Diferentes clados apresentam relações caracteristicas no tempo de formação, que tornam os estudos acerca da ontogenia dos membros dos tetrápodes um dos principais e mais bem conhecidos modelos no campo da biologia do desenvolvimento (Johnson e Tabin, 1997; Gilbert, 2006).

Os membros são considerados módulos praticamente autônomos que seguem uma sequência de desenvolvimento muito bem estruturada por cascatas de expressão de genes, que 
coordenam a construção de uma estrutura completa e funcional. Estudos experimentais sobre o desenvolvimento destes segmentos mostraram que as regras básicas de construção são conservadas para os Tetrapoda (Shubin e Alberch, 1986), com moléculas de sinalização que desempenham papel fundamental na determinação dos três eixos do membro: fator de crescimento do fibroblasto (FGF), regulando o eixo próximo-distal; Sonic Hedgehog, regulando o eixo ântero-posterior e Wnt7a, regulando parte do eixo dorso-ventral (Gilbert, 2006). Tais morfógenos de padronização estão presentes e são conservados em todos os animais segmentados.

Segundo Searls e Janners (1971) e Wagner e Chiu (2001), os membros dos Tetrapodas surgem de um conjunto de células da placa lateral do mesoderma que orientam o desenvolvimento em brotos mesenquimais sobrepostos por ectoderma. O crescimento continua distalmente e parte do ectoderma forma a Crista Apical Ectodermal (AER), sendo essencial para continuidade da formação dos brotos dos membros em Amniota (Fig. 4) (embora ausente em urodelas) (Karczmar e Berg, 1951, Richardson et al., 1998).

Três fases distintas de expressão de Abd-B-like, HoxA e HoxD grupo 9-13 genes no desenvolvimento de galinha e ratos foram descrito para os membros. Na primeira fase os genes Hoxa-9 e Hoxd-9 e Hoxa-10 e Hoxd-10 são expressos uniformemente no mesoderma. Na fase 2 Hoxa-9 e Hoxa-13 são sequencialmente ativados no broto do membro. Durante a fase 3 ocorre o desenvolvimento quando o autopodio é formado. Hoxd-10 e Hoxd-13 são sequencialmente ativados em ordem inversa. Nesta fase, estudos revelam que existe uma dependência da liberação de substâncias pelo AER como o FGF (Fig. 4) (Vargesson et al., 2001).

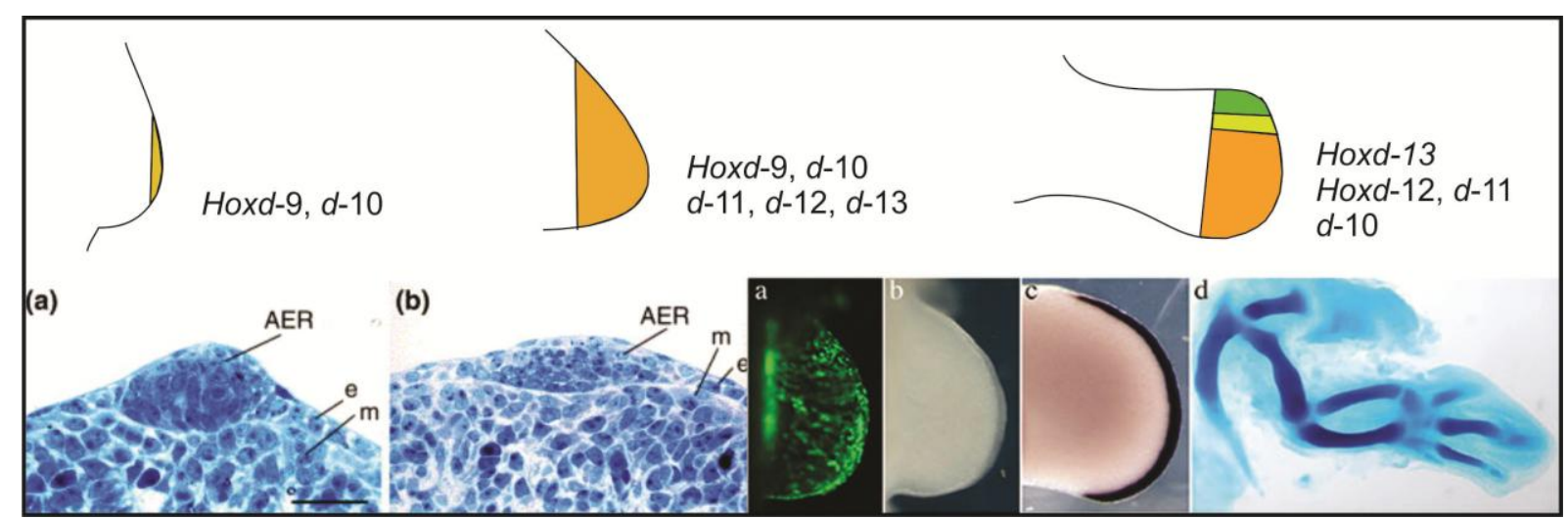

Figura 4: Desenvolvimento do broto dos membros em Tetrapoda. Representação esquemática da formação da Crista Apical Ectodermal. Corte transversal do broto do membro evidenciando a AER. Fotografias do desenvolvimento do membro. Adaptado: Arcangelis et al., 2000; Casanova et al., 2015. 
Existem evidências que a condrificação da condensação mesenquimal na parte proximal do membro seja resultado de diferentes mecanismos moleculares, mas o padrão ontogenético deste desenvolvimento foi relatado por Shubin e Alberch (1986) com base em conexões espaciais entre as condensações cartilagíneas e nos eventos de bifurcação destas condensações. Eles esclareceram esta etapa da formação a partir do desenvolvimento do eixo primário, termo consagrado na literatura com foco na ontogenia dos membros. Fazem parte deste o úmero/fêmur, que alonga-se e sofre ramificação para formar a ulna e rádio/fíbula e tíbia. Estendem-se ainda através da ulna/fíbula, ulnar /fibular e os elementos distais e do dígito IV (Fig. 5).

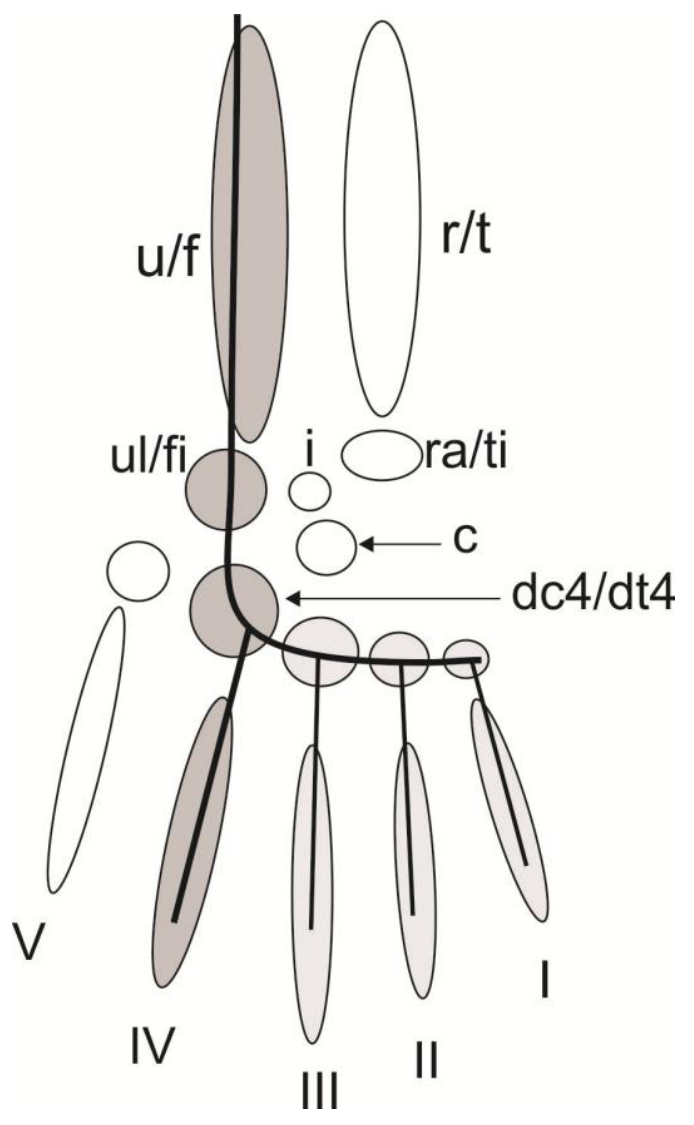

Figura 5: Representação esquemática da condensação cartilagínea dos membros em Tetrapoda. As estruturas marcadas pela cor escura representam o eixo primário, tal como evidencia o traço de maior espessura. As demais estruturas marcadas com cor clara e traços menos espessos formam o arco digital. $\mathrm{O}$ dígito $\mathrm{V}$ se forma por condensação independente, tal como as demais estruturas da região central do autopódio. Embora os elementos centrais tenham sido representados por apenas um componente, esta não corresponde a quantidade de estruturas. r, rádio; ra, radial; u, ulna; ul, ulnar; f, fíbula; fi, fibular; t, tíbia; ti, tibial; c, central; i, intermédio; dc4, distal do carpo 4; dt4, distal do tarso 4. Adaptado: Shubin e Alberch, 1986. 
Diversos autores concluíram que esta é a característica conservada e invariável no desenvolvimento dos membros dos Tetrapoda (Müller e Alberch, 1990; Blanco e Alberch, 1992; Burke e Feduccia, 1997; Sánchez-Villagra et al., 2008, 2009; Sheil e Portik, 2008; Kundrát, 2009; Hugi et al., 2010; Leal et al., 2010; Vieira et al., 2010).

Adicionalmente aos estudos de ontogenia dos membros, é necessário discutir o padrão molecular deste desenvolvimento. Em diversas espécies ocorre redução dos elementos que formam os dígitos ou o membro. Tais processos envolvem genes que regulam a expressão de falanges, metacarpos e carpos em mecanismos de redução e fusão destes elementos. Shapiro et al. (2003) relataram para Hemiergis ssp. que a perda dos dígitos é regulada pela inativação de Sonic Hedgehog haja vista que este é responsável pela ativação desta característica. Tal fato poderia estabelecer a evolução paralela ou convergência genética visto a diversidade morfológica observada nestes lagartos (Shapiro et al., 2006). A ligação entre o desenvolvimento dos membros aparece como o resultado de padrões genéticos onde os Genes Hox, estão envolvidos neste processo de evolução (Shubin et al., 1997), sendo a genética responsável por prover um arcabouço para integração evolutiva e transmissão dessas características.

\section{Estágios embrionários}

Estabelecer uma linguagem comum entre os diversos trabalhos existentes para várias espécies diferentes tem sido difícil devido à escassez de dados comparativos deste nível (Richardson et al., 1999; Richardson et al., 2001; Richardson e Keuck, 2002; Richardson e Verbeek, 2003). Embora, para diferentes espécies, embriões foram descritos em estágios filotípicos (Richardson, 1995; Werneburg, 2009).

As características morfológicas externas são uma importante fonte de informações para determinação dos estágios (Hamburger e Hamilton, 1992; Beggs et al,. 2000) sendo necessário a análise de um conjunto de características padrão (Werneburg, 2009). A embriologia dos répteis é uma área de estudo antiga. Diferentes investigações forneceram dados para o estabelecimento de estágios embrionários de vários representantes do grupo. Yntema (1968) descreveu os estágios embrionários para Chelydra serpentina, oferecendo um primeiro padrão consistente para o desenvolvimento de investigações com este foco. Magnusson e Taylor (1980) fizeram o mesmo para Crocodylus porosus, Ferguson (1987) para Alligator mississippiensis, Iungman et al. (2008) para Caiman latirostris, Vieira et al. (2011) para Melanosuchus niger, Greenbaum e Carr (2002) para Apalone spinifera, Werneburget et 
al. (2009) para Emydura subglobosa, Tokita e Kuratani (2001) para Pelodiscus sinensis, Boughner et al. (2007) para Python sebae entre outros.

Tais investigações possibilitaram, a partir desta padronização, o estabelecimento de diversas outras investigações acerca da ontogenia destas espécies como o desenvolvimento das estruturas de sustentação e suporte do esqueleto cartilagíneo e ósseo, de sistemas viscerais como, por exemplo, o renal que, dentre outros, permitiu aos répteis uma maior dispersão pelo ambiente terrestre.

Antes da identificação e aplicação de algumas questões mais especificas é necessário esclarecer algumas questões estruturais dos grupos de interesse. O conhecimento das variações morfológicas e de outras peculiaridades do desenvolvimento pode contribuir para a formulação de hipóteses sobre as mudanças genéticas, morfológicas e evolucionarias durante a evolução (Boughner et al., 2007)

Infelizmente até pouco tempo atrás o uso de uma linguagem comum para definir caracteres em estudos embriológicos, criando um grande modelo comparativo, balizou o conhecimento neste campo. Segundo Weneburg (2009), o histórico para tais trabalhos remete à clara definição topológica para embriões humanos (Soemmerring, 1799), extrapolando estes dados para o desenvolvimento dos vertebrados. Recentemente, o uso de padrões com métodos de heterocronias, definiram a base para análises de diferentes padrões de desenvolvimento entre as espécies em um contexto filogenético (Mabee e Trendler, 1996; Smith, 1997; Velhagen, 1997; Schlosser, 2001; Jeffery et al., 2002, 2005; Schulmeister e Wheeler, 2004; Harrison e Larsson, 2008). Este método compara eventos, caracteres em desenvolvimento (Bininda-Emonds et al., 2002) e introduziu uma nova abordagem para investigações em embriologia e desenvolvimento comparativa, onde os embriões não apresentam uma fase comum com alto grau de conservadorismo nos caracteres morfológicos (Richardson et al., 1997), abolindo o pensamento tipológico (Haeckel, 1868, 1874 apud Weneburg, 2009; Richardson et al., 1999).

Uma variedade de dados acerca da biologia do desenvolvimento dos répteis (inclusive aves) está disponível na literatura (Hall, 1992; Breuker et al., 2006, Boback et al., 2012). Genericamente estas investigações utilizaram certos critérios para organizar uma tabela de desenvolvimento normal. É consenso que o trabalho de Yntema (1968) foi o primeiro a compilar dados mais significativos acerca do tema, embora alguns dados tenham sido publicados anteriormente por outros autores de maneira mais simplista (Agassiz, 1857; Deraniyagala, 1939; Carr e Hirth, 1961; Schu1z, 1975; Mrosovsky e Yntema, 1980). 
Tabelas de desenvolvimento foram produzidas para crocodilianos como Melanosuchus niger (Vieira et al., 2011), Caiman latirostris (Iungman et al., 2008), Alligator mississippiensis (Fergunson, 1985, 1987), A. sinensis (Tian-Miao et al., 2004) com 28 estágios e Crocodilus porosus (Magnunssun e Taylor, 1980) com 15 estágios. Os testudines Chelydra serpentina (Yntema, 1968) e Peludiscus sinensis (Tokita e Kuratani, 2001) com 27 estágios, Podocnemis expansa (Danni et al., 1990), P. unifilis (Lima et al., 2012), Apalone spinifera (Greenbaum e Carr, 2002), 26 estágios, Chrysemys picta (Mahmoud et al., 1973) com 23 estágios e Lepidochelys olivacea (Crastz, 1982; Renous et al., 1989) com 31 estágios; e, ainda, as serpentes Thamnphis sirtalis sirtalis (Zehr, 1962) com 26 estágios, Elaphe obsoleta (Haluska e Albrecht, 1983) com 28 estágios e, para Python sabae, 10 estágios (Boughener et al., 2007). No mais, alguns autores tem se ocupado em descrever possíveis alterações na cronologia e na sequência do desenvolvimento com possíveis implicações filogenéticas (Jeffery et al., 2005; Weneburg, 2009; Boback et al., 2012).

Antes da descrição e padronização destes estágios de desenvolvimento muitos pesquisadores usaram o padrão de medidas do corpo para estimar a idade aproximada dos embriões (Risley, 1932), ocorrendo erros constantes. De fato, se correlacionados corretamente as dimensões e características morfológicas com a idade real pode ser possível estimar o período de postura, incubação e estimar a data de eclosão (Vieira et al., 2011). Contudo, as avaliações baseadas apenas na cronologia são muito falhas, especialmente devido as variações no período de incubação, bastante influenciáveis pelas característica ambientais, o que pode gerar diferenças em embriões de um mesmo ninho (Donayo et al., 2002)

Quando comparamos a embriologia de diversos grupos de vertebrados é obvia a necessidade de um padrão para descrever as características durante o início do desenvolvimento. Um problema frequente para aplicação experimental é a escassez de dados acerca do desenvolvimento de várias espécies. Tabelas contendo informações embriológicas para lagartos incluem Lacetilia (Dufaure e Hubert, 1961) e Iguanide (Lemus, 1967), alguns apenas para lagartos ovíparos (Muthukkruppan et al., 1970; Blanc, 1974; Lemus et al., 1981, Sanger et al., 2008).

O estabelecimento de Iguana iguana iguana (Linnaeus, 1758) como táxon modelo experimental para estudos biológicos diversos está consolidado por várias investigações (Butler e Northcutt, 1973; Foster e Hall, 1975; Throckomorton, 1976; Janke et al., 2001). Detalhes do desenvolvimento embrionário, contudo, não foram contemplados, e o estabelecimento de uma sequência de formação embrionária é de grande importância para a padronização de uma linguagem comum. 


\section{OBJETIVOS}

\subsection{OBJETIVO GERAL}

Elucidar aspectos da ontogenia em I. iguana iguana em diferentes estágios de desenvolvimento.

\subsection{OBJETIVOS ESPECÍFICOS}

Descrever os estágios embrionários de desenvolvimento de I. iguana iguana;

Descrever o esqueleto adulto;

Determinar a ordem de aparecimento das cartilagens formadoras do modelo do esqueleto;

Determinar a ordem de aparecimento dos centros de ossificação dos elementos esqueléticos;

Comparar a ordem de aparecimento da cartilagem com os centros de ossificação nos elementos esqueléticos com outras espécies reportadas na literatura. 


\section{MATERIAL E MÉTODOS}

\subsection{Manutenção dos ovos e Coleta dos embriões}

Ovos de I. iguana iguana foram obtidos de uma colônia mantida em cativeiro, um criadouro científico alocado no Jacarezário do Departamento de Zoologia da Universidade Estadual Paulista "Júlio de Mesquita Filho" - UNESP, e incubados em caixas plásticas contendo vermiculita em uma sala climatizada (Eletrolab modelo EL011), à temperatura constante de $30^{\circ} \mathrm{C}\left( \pm 0,1^{\circ} \mathrm{C}\right)$.

Foram realizadas três coletas durante ciclos de reprodução de três diferentes anos (2009, 2012 e 2013).

\section{Coleta 1}

No ano de 2009, ovos de duas ninhadas distintas foram coletados, transportados e incubados de acordo com o relato supracitado. A partir do dia da desova e a cada um dos nove dias subsequentes, quatro embriões de uma mesma ninhada foram coletados. No décimo dia após a oviposição, um embrião foi coletado em intervalos de dois dias até a eclosão. Os referidos foram fixados e mantidos em solução de formalina a $10 \%$ neutro. Sob condições controladas o período de incubação foi de 75 dias, totalizando 68 embriões coletados para as duas ninhadas.

\section{Coleta 2}

No ano de 2012, foram utilizadas ninhadas diferentes e os ovos aleatoriamente coletados, diariamente e os embriões fixados em solução de formalina a 10\% por 24 horas e posteriormente transferidos e mantidos em álcool 70\%. Sob condições controladas o período de incubação foi de 65 dias, totalizando 65 embriões coletados.

\section{Coleta 3}

No ano de 2013, ovos de uma ninhada foram recolhidos e os embriões coletados diariamente a partir da oviposição até o vigésimo dia de incubação. Estes foram fixados em solução de formalina a $10 \%$ por 24 horas e posteriormente transferidos e mantidos em álcool $70 \%$, totalizando 20 espécimes.

Os embriões foram removidos de seus ovos, cortando-se a casca com tesoura cirúrgica, isolando-os do vitelo e dos seus envoltórios. A eutanásia foi realizada com Tiopental 50mg/Kg. A coleção foi encaminhada ao Laboratório de Anatomia da Universidade Federal de Goiás - Regional Jataí. 
A colônia de iguanas mantidas na UNESP - Rio Claro - SP é devidamente licenciada pelo ICMBIO - IBAMA - No. 973766. As coletas, bem como os métodos de eutanásia aplicados foram aprovados pelo comitê de ética no Uso Animal da Unesp Campus de Rio Claro sob protocolo CEUA 4173/2009 (Anexo I).

A amostra totalizou 153 embriões que foram oferecidos a título de empréstimo para pesquisa (Anexo II), respaldado pela Instrução Normativa número 154, de 01 de março de 2007 do IBAMA. Embora as coletas iniciais tenham sido aprovadas pelo CEUA da UNESP para desenvolvimento de outro projeto de pesquisa, julgamos prudente solicitar o parecer para esta pesquisa. Os procedimentos metodológicos foram então submetidos à apreciação e aprovados pelo comitê de ética no Uso Animal da Universidade Federal de Uberlândia sob protocolo CEUA 070/2012 (Anexo III).

\subsection{Determinação dos estágios de desenvolvimento}

Os estágios de desenvolvimento foram identificados com base nos critérios estabelecidos na literatura (Werneburg, 2009) a partir das características morfológicas externas. Cada espécime foi minunciosamente analisado e suas principais características morfológicas relacionadas a cada etapa do desenvolvimento. Os estágios foram classificados, alinhados e correlacionados de acordo com investigações anteriores para lagartos (Sanger et al., 2008; Noro et al., 2009, Wise et al., 2009).

Para espécimes nascidos e criados em cativeiro a oviposição ocorre no estágio 28-29, e a eclosão a partir do estágio 42. Como em outros répteis (incluindo aves), a cronologia de cada estágio é bem variável e o tempo absoluto em cada espécie não pode ser utilizado para comparações intra ou interespecíficas (Billet et al., 1985). As alterações na morfologia são utilizadas como subsídio para tais comparações.

Detalhes do desenvolvimento dos membros são importantes para o estabelecimento dos estágios. Outras variáveis importantes são os arcos faríngeos (incluindo processos maxilar e mandibular), olhos e anexos, escamas, pigmentação e desenvolvimento do dente de ovo. Os estágios embrionários foram descritos de acordo com o aparecimento de diferentes características morfológicas externas. As principais estruturas ou caracteres utilizados como parâmetros foram: arcos faríngeos, somitos, membros, garras, estruturas nasais, papila urogenital, cloaca, pálpebra, pigmentação, escamas, dentes e dente de ovo. Para observação detalhada de tais estruturas utilizou-se um microscópio estereoscópico, lupa e câmera digital (Sony Cyber-Shot DSC-H20 10.1mp) para captura das imagens. 
Embriões dos sete primeiros dias de incubação de uma mesma ninhada da Coleta 1 foram submetidos a microscopia eletrônica de varredura (MEV) com objetivo de evidenciar características pormenorizadas de sua anatomia externa. As amostras foram fixadas em solução de glutaraldeído $2 \%$ e paraformaldeído $2 \%$ diluída em solução tampão cacodilato de sódio $0,1 \mathrm{M}$, sendo posteriormente imerso em solução de ósmio $1 \%$. Em seguida estes foram submetidos ao processo de desidratação em soluções aquosas de acetona 30, 50, 70 e 90\% e três banhos em acetona pura, por 15 minutos cada. O material foi seco ao ponto crítico com $\mathrm{CO}_{2}$ e metalizado em sputter coater.

\subsection{Diafanização e coloração de ossos e cartilagens}

Uma coleção de embriões constando toda sequência ontogenética foi selecionada, diafanizada e suas cartilagens e ossos corados com Alcian Blue e Alizarina red S, respectivamente (Dingerkus e Uhler, 1977; Davis e Gore, 1936). Da coleta 1 foi preparada uma sequência com dois espécimes de cada estágio. Visto as análises preliminares, da coleta 2 foram preparados um espécime de cada estágio e adicionalmente outro para os estágios 34 a 40. O total de embriões corados foi de 41 espécimes.

Para coloração das cartilagens, as etapas corresponderam na fixação por formaldeído neutro (10\%) por 48 horas. Embriões dos estágios 40 a 44 permaneceram na solução por 4 dias. Lavagem em água destilada por 72 horas, coloração em solução de Alcian Blue por 48 horas, hidratação em séries de solução de etanol por 24 horas $(95 \%, 90 \%, 80 \%, 70 \%, 40 \%$, 15\%), lavagem por 24 horas em água destilada e transferência para solução saturada de borato de sódio por 72 horas (três trocas em intervalos de 24 horas).

Posteriormente foi realizado o clareamento por hidróxido de potássio $(\mathrm{KOH} 2 \%$ para embriões a partir do estágio 38 e $1 \%$ para anteriores), coloração dos ossos por Alizarina red S durante 30 minutos e conservação do material em soluções crescentes de glicerina (15\%, $30 \%, 50 \%, 90 \%$ e glicerina pura) trocadas em intervalos de 24 horas.

Para análise do material foi utilizado uma lupa trinocular com sistema de captura de imagem. 


\subsection{Preparação e descrição do esqueleto adulto}

Dois espécimes machos, adultos, pertencentes ao acervo do Laboratório de Zoologia da UNESP - Rio Claro foram preparados para descrição do esqueleto. Ambos os animais vieram a óbito por causas naturais sendo então retirados do recinto e congelados.

Os cadáveres foram transferidos para o laboratório de Anatomia da UFG onde tiveram todo o tecido mole (tegumento, músculos e vísceras) removido com auxílio de bisturi, tesoura e faca deixando o esqueleto exposto e o mais limpo possível. Alguns segmentos foram desarticulados (membros, coluna vertebral, cauda e crânio) e levados à cocção por algumas horas, o que possibilitou a limpeza completa.

Os ossos foram deixados individualmente em solução de peróxido de hidrogênio (3\%) por 24 horas, objetivando a limpeza e clareamento do material. Posteriormente os ossos foram identificados, descritos detalhadamente e fotografados para documentação (Sony Cyber-Shot DSC-H20 10.1mp).

\subsection{Investigação histológica}

Alguns espécimes foram submetidos ao protocolo histológico com coloração de Hematoxilina e Eosina. Fragmentos dos membros (estágios 32 a 38 e 42) e globos oculares (estágios 34 a 38) foram desidratados por 30 minutos em solução etílica (70\%, 80\%, 90\%, 95\% e 100\%), diafanizados em xilol (3 banhos de 30 minutos cada), inclusos em parafina (3 banhos de 20 minutos cada) e submetidos a cortes em diferentes espessuras $(6,10,14 \mu \mathrm{m})$.

Após a preparação das lâminas, os cortes foram corados com H.E. Para retirada da parafina foram feitos 3 banhos de um minuto cada em xilol e posteriormente em solução etílica $(100 \%, 95 \%$ e $70 \%)$ por um minuto cada, permanecendo 30 segundos em água destilada. Feita a hidratação os cortes foram submersos em solução de hematoxilina por 3 minutos, lavados em água corrente por 2 minutos, colocados em solução de eosina por 2 minutos e novamente lavados em água corrente por 5 minutos. Antes da montagem das lâminas, foram feitos 3 banhos de um minuto cada em xilol.

Devido ao estágio inicial de ossificação não foi utilizada nenhuma técnica de descalcificação. Imagens dos cortes foram adquiridas com auxílio de um microscópio com sistema de captura de imagens (Leica ICC50 HD). 


\subsection{Terminologia adotada}

Para identificação e descrição das estruturas esqueléticas foram utilizadas as terminologias propostas por Romer (1956), Jolie (1960) e Hildebrand e Goslow (2006). Para identificação das condensações cartilagíneas e padrão de ossificação Burke e Alberch (1985), Shubin e Alberch (1986), Fabrezi et al. (2007) e Fontanarrosa e Abdala (2014) e para descrição dos estágios embrionários Hamburger e Hamilton (1951), Defaure e Hubert (1961), Noro et al., (2009), Werneburg (2009) e Wise et al. (2009). 


\section{RESULTADOS}

\subsection{DESCRIÇÃO ANATÔMICA DO ESQUELETO ADULTO}

\section{Esqueleto Axial}

\section{Crânio}

\section{Dematocrânio}

Premaxila (Pm) - posicionado na porção mais rostral do crânio, este elemento forma a margem rostromedial da narina e a margem medial de cada fenestra nasal externa. A premaxila possui uma estreita projeção orientada dorso-caudalmente, o processo nasal, que se estende entre a porção rostral dos ossos nasais. Sua parte rostral é mais larga, apresentando uma face inferior alveolar. Este osso articula com a maxila rostrolateralmente e com os nasais caudalmente. A delgada e afilada projeção do processo nasal articula-se com o corno frontomedial de cada nasal. Ventralmente existe um pequeno processo que se projeta na transição com o osso vômer, o processo incisivo (processo palatino). Ao longo da margem ventral a premaxila exibe uma crista alveolar que fornece sustentação para cinco dentes. Rostralmente existe um par de forames (Figs. 6 e 7).

Septomaxila (sp) - esta localizado dorsoventralmente na cavidade nasal. Repousa rostromedialmente entre as cápsulas nasais, lateralmente ao septo nasal. Formam o assoalho e a porção rostromedial da cavidade nasal, além do teto da cavidade que contem o órgão vomeronasal. A septomaxila é orientada rostroventralmente e articula se com a maxila rostrolateralmente, com o vômer ventralmente e a premaxila rostralmente.

Maxila (ma) - ocupa grande porção da face rostrolateral do crânio. Em vista lateral, cada maxila estende-se aproximadamente até a metade do comprimento do crânio. Sua porção mais caudal estende-se até a metade da fenestra orbital. Articula-se com a premaxila, septomaxila, nasal, pré-frontal, lacrimal e jugal. A projeção caudal é denominada processo facial preorbital, sendo ligeiramente côncava, formando as margens ventral e dorsocaudal da fenestra nasal. Seguindo a margem alveolar existe uma fileira de forames alveolares (em média de sete pequenas aberturas) na porção ventral da margem facial. A margem rostrodorsal do processo facial forma a margem ventromedial da fenestra nasal. A metade caudal da porção facial da maxila é alongada, contatando o jugal, superiormente, em toda sua extensão. 


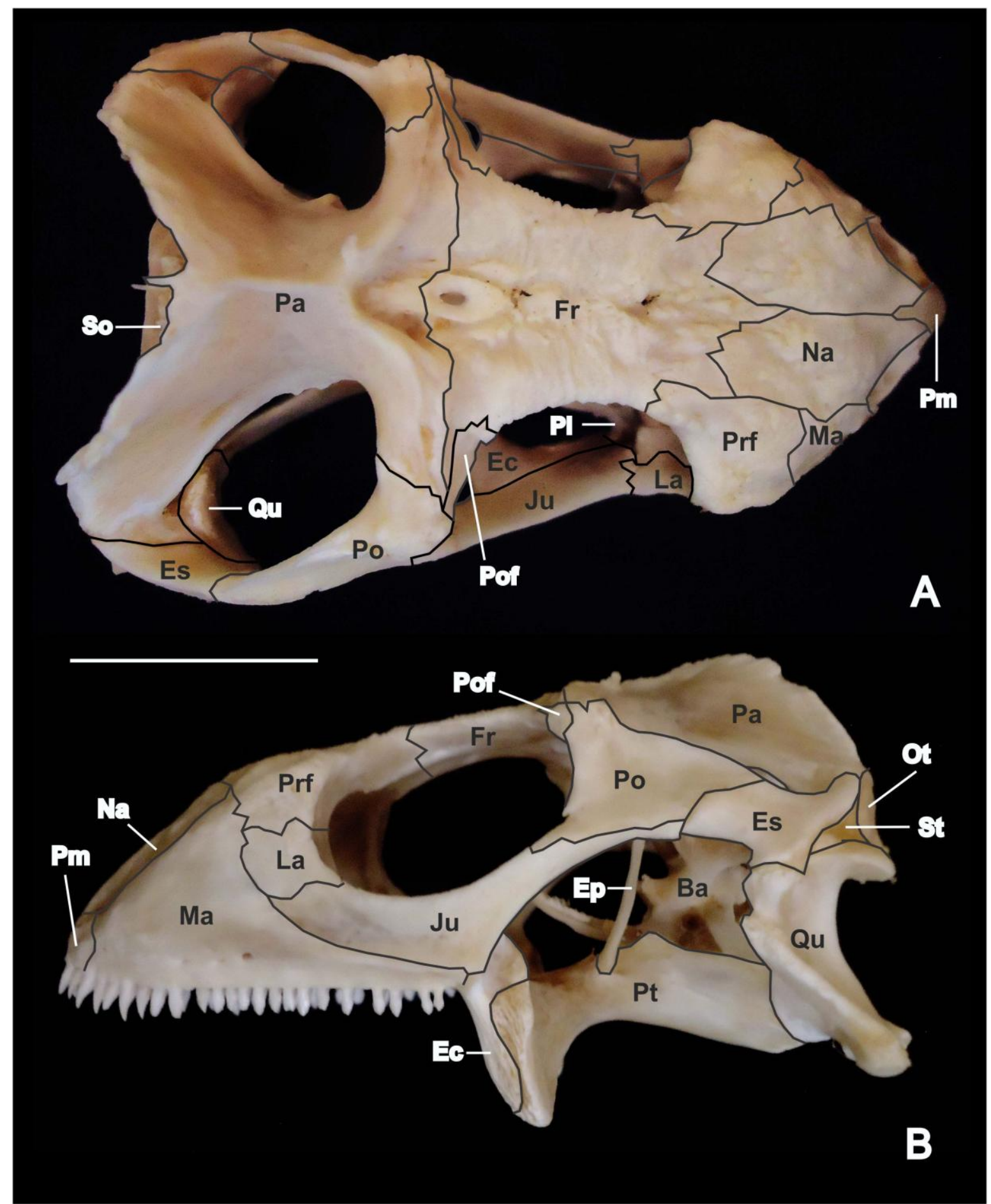

Figura 6: Crânio de I. iguana iguana adulta. Vista dorsal (A) e lateral (B). Pm, pré-maxila; Na, nasal; Ma, maxila; La, lacrimal; Prf, pré-frontal; Ju, jugal; Fr, frontal; Ec, ectopterigóide; Pt, pterigoide; Ep, epipterigóide; Pof, pós-frontal; Po, pós-orbital; Pa, parietal; Es, esquamosal; Ba, basisfenóide; Qu, quadrado; Ot, otoccipital; St, supratemporal; Pl, palatino; So, supraoccipital. Barra $3 \mathrm{~cm}$. 
A porção da maxila que suporta os últimos oito dentes está inserida no assoalho da órbita dorsalmente, limitando a fenestra palatina lateralmente, em vista ventral. Contata ainda o ectopterigóide e o palatino. Cada maxila sustenta 26 dentes dispostos em uma fileira alveolar bem desenvolvida. Cada fileira alveolar percorre a margem lateral das fenestras exochoanalis e vomeronasal externa, ventracaudal e ventrorostralmente, respectivamente. As referidas fenestras são contínuas (Figs. 6 e 7).

Nasal (Na) - articulam-se rostralmente com o processo nasal da premaxila e caudalmente contatam o frontal, formando assim grande parte da capsula nasal. A metade posterior dos nasais são ventralmente côncavas e formam uma depressão conspícua no crânio. Cada nasal se articula com a premaxila, maxila, pré-frontal e frontal. Ainda contatam seu contralateral formando a sutura internasal. A articulação nasal-prefrontal é interrompida caudalmente pelo delgado processo anterolateral do frontal, que se estende até a porção rostral do lacrimal. Rostralmente o nasal forma a margem posterodorsal da fenestra nasal, exibindo dois processos rostrais, um medial mais proeminente, o corno rostromedial que contata o processo nasal da premaxila e outra projeção lateral, o corno rostrolateral, que contata a maxila. A superfície dorsal de cada nasal apresenta três ou quatro pequenos forames arranjados obliquamente. Sua superfície rostral é lisa enquanto sua porção caudal exibe uma ornamentação similar àquela apresentada pelo frontal (Fig. 6).

Pré-frontal (Prf) - estão posicionados na face rostrolateral do crânio e formam a margem rostrodorsal da orbita e posterior da parede da capsula nasal. Pré-frontal, frontal e palatino formam a borda da fenestra orbitonasal que comunicam as cavidades nasal e orbital. Cada pré-frontal articula-se com o nasal e frontal dorsomedialmente, com a maxila rostrodorsalmente e com o lacrimal ventrolateralmente. Em vista caudal cada osso articula-se com o lacrimal lateralmente. Entre este e o lacrimal existe um forame ovalado, o forame lacrimal, entalhado na face caudal deste e que da passagem para a cavidade nasal. Na superfície dorsal, este osso exibe uma projeção similar a uma lanceta que contata o frontal e forma uma sutura com encaixe entalhado (Fig. 6).

Lacrimal (La) - são ossos pequenos e lateralmente dispostos na órbita, contribuindo para a formação da porção rostral desta, juntamente com o pré-frontal e jugal. Cada lacrimal articula-se com a maxila rostralmente, jugal ventrolateralmente e caudomedialmente e, préfrontal dorsal e medialmente. A porção medial cada lacrimal é escavada e forma a parede lateral do forame lacrimal (Fig. 6). 


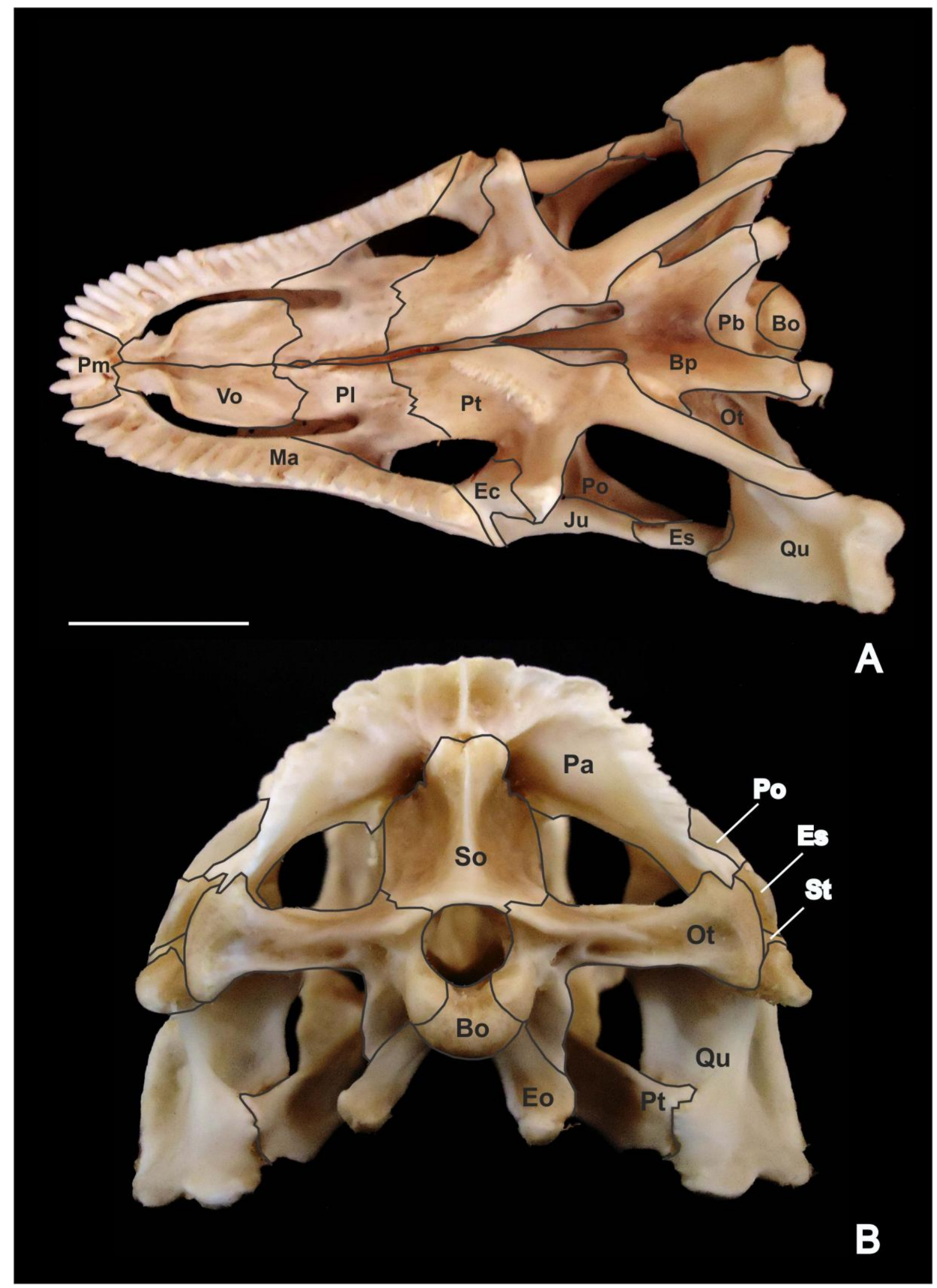

Figura 7: Crânio de I. iguana iguana adulta. Vista ventral (A) e caudal (B). Pm, pré-maxila; Vo, vômer; Ma, maxila; Ju, jugal; Ec, ectopterigóide; Pl, palatino; Pt, pterigóide; Po, pósorbital; Es, esquamosal; Bo, basioccipital; Ot, otoccipital; $\mathrm{Qu}$, quadrado; $\mathrm{Pb}$, parabasisfenóide; Bp, basipterigóide; So, supraoccipital; Pa, parietal; Eo, exoccipital; St, supratemporal. Barra $2 \mathrm{~cm}$. 
Frontal (Fr) - situado entre as órbitas forma a maior parte da margem dorsal destas. É tão longo quanto largo e apresenta ornamentações. Exibe forma quadrangular com a presença rostral de duas projeções laterais, os processos rostrolaterais que contatam cada nasal e pré-frontal e outra projeção mediana, processo rostromediano, que se encaixa em forma de entalha na porção mais caudal da sutura internasal. A margem transversa posterior do frontal finda na margem caudomedial da órbita e se articula com a margem rostral do parietal. Medialmente, a margem posterior do frontal é escavada para formar a margem do forame pineal. Este forame é conspícuo na porção mais dorsal do frontal. Apresenta bordas espessadas e salientes e sua abertura é ovalada. Caudalmente o frontal articula com a margem rostromedial do pós-frontal. A face ventral do frontal é ligeiramente côncava e lisa. Na porção rostral existe uma crista que se direciona lateralmente e contata o pré-frontal. Entre estas cristas destaca-se uma fossa rasa que avança pela face ventral do nasal, rostralmente, e forma o teto da cavidade nasal (Fig. 6).

Parietal (Pa) - forma a maior porção da superfície do crânio e apresenta uma ornamentação similar ao padrão de escamas da superfície. Lateralmente o parietal é côncavo e forma a borda medial e rostral da fenestra supratemporal. O corpo do parietal sustenta um par de processos rostrolaterais, bem como um par de longos processos supratemporais. Uma proeminente lâmina ventrolateral descendente conecta estes processos. O corpo do parietal, ou sua porção média, apresenta uma crista longitudinal que rostralmente se bifurca em direção aos processos rostrolaterais, assumindo uma forma de Y. Estendem-se da extremidade caudal até próximo a borda caudal do forame pineal onde bifurca. Cada processo rostrolateral é robusto e articula-se com a metade caudal da margem do pós-frontal anteriormente e com o processo caudal do pós-orbital lateralmente. O processo supratemporal é orientado ventralmente, assumindo a forma de uma lamina larga e ligeiramente côncava laterorostralmente. Sua margem ventral é extremamente delgada e lisa, delimitando a margem medial da fenestra supratemporal. A borda dorsal forma um ângulo obtuso, apresentando uma forma similar a um U ou V mais aberto. Possui bordas salientes e rugosas e uma espícula delgada na porção mediana, caudalmente. A extremidade caudal de cada processo supratemporal articula-se com o processo paraoccipital do otoccipital. A margem transversa anterior do parietal articula-se com a margem caudal do frontal e encerra o forame pineal medialmente. Este forame é fechado por um entalhe medial na margem caudal do frontal, não recebendo contribuição direta do parietal. Medialmente a superfície caudoventral do parietal exibe a fossa parietal, que contata a extremidade do processo ascendente do supraoccipital. 
Este exibe ainda uma pequena projeção lateral e ventralmente direcionada, o processo medioventral, que contata a extremidade dorsal do epipterigóide. Sua superfície ventral apresenta duas cristas bem definidas que delimitam um sulco central, além de duas projeções triangulares voltadas ventralmente que contatam intimamente a face medial do processo ascendente do supraoccipital (Figs. 6 e 7).

Supratemporal (St) - estão lateralmente dispostos e comprimidos entre o parietal, esquamosal, quadrado e otoccipital na porção caudal do crânio. Cada osso repousa inteiramente na porção caudoventral da superfície lateral do processo supratemporal do parietal. A extremidade anterior de cada supratemporal se estende até o outro lado da fossa supratemporal, contudo, posteriormente articula-se com a extremidade distal do processo paraoccipital do otoccipital, o côndilo cefálico do quadrado, a extremidade posterior do esquamosal, e a cartilagem intercalar (Fig. 6).

Pós-frontal (Pof) - são pequenos, planos e quadrangulares. Formam a margem caudal das orbitas. A margem medial de cada osso articula-se com o processo rostrolateral do parietal caudalmente e sua extremidade caudal com a margem lateral do frontal, rostralmente. A margem laterocaudal do pós-frontal contata a margem rostral do processo dorsal de cada pós-orbital (Fig. 6).

Pós-orbital (Po) - são ossos trirradiados que ocupam a superfície laterocaudal do crânio, caudalmente posicionados em relação às órbitas. Sua margem rostral contribui para a formação da borda caudoventral da orbita, enquanto que a margem caudal forma a borda lateral da fenestra supratemporal. Cada pós-orbital forma a metade rostral do arco supratemporal. Dorsocaudalmente orientada, a margem ventral é larga e sua borda é plana e delgada, articulando-se com o jugal e o esquamosal. O processo dorsal deste estende-se dorsalmente e se articula com a margem caudal do pós-frontal rostralmente e com o processo rostrolateral do parietal medialmente. Lateralmente a articulação com o pós-frontal, o processo dorsal suporta um pequeno porém amplo processo pós-orbital (Fig. 6).

Esquamosal (Es) - não apresentam forma definida, sendo levemente alongados e delgados, apresentando três extremidades. Contribuem para a formação da margem laterocaudal da fenestra supratemporal. Caudalmente o esquamosal é largo e se articula com a extremidade caudal do supratemporal e ventralmente com o côndilo cefálico do quadrado. Dorsalmente contata o processo supratemporal do parietal através de um processo dorsal ascendente. Rostralmente forma uma sutura oblíqua com o pós-orbital, fechando lateralmente a fenestra supratemporal (Figs. 6 e 7). 
Jugal (Ju) - é um osso alongado e laminar com aspecto levemente sigmoide. Contribui para formação de toda a margem ventral da órbita. Cada jugal é composto por dois processos alongados que apresentam curvaturas em sentidos opostos. $\mathrm{O}$ processo rostral, ou maxilar, articula-se com a porção ventrocaudal da maxila (processo facial) e posteromedialmente com a margem dorsal do processo rostrolateral do ectopterigóide, e rostralmente com o lacrimal. A metade dorsal da margem rostral do processo temporal se articula com a porção anterior da margem ventral do pós-orbital. Este processo temporal ainda contata o esquamosal em sua porção mais caudal (Figs. 6 e 7).

Vômer (Vo) - elemento mais rostral do palato e forma a borda medial de cada fenestra vomeronasal externa rostrolateralmente, ocupando aproximadamente três quartos do comprimento da margem medial de cada fenestra exochoanalis, caudalmente. Articulam-se entre si formando uma sutura intervomeriana. Rostralmente contatam a premaxila através de uma projeção que se destaca na porção ventral do palato. Nesta face existem duas cristas sinuosas que contornam a porção óssea mais próximo a margem medial da fenestra vomeronasal. Na superfície dorsal existe um pequeno entalhe rostral, marcado por uma crista evidente na linha mediana, que corresponde à margem medial da fenestra vomeronasal. Caudalmente o vômer contata o palatino formando uma sutura sinuosa. No aspecto geral este osso é ligeiramente côncavo ventralmente (Fig. 7).

Palatino (PI) - São medialmente separados por um estreito e alongado espaço piriforme. Este pode não apresentar-se continuo devido ao posicionamento de ambas as placas osseas, formando pequenos espaços ou forames entre os palatinos. Este é formado por três processos (vomeriano rostromedial, pterigóide caudal e maxilar rostrolateralmente). Os processos vomerianos sobrepõem o vômer na porção mais caudal do palato, formando uma sutura. A borda rostral do processo maxilar forma a margem caudal da fenestra exochoanalis, contatando ainda, lateralmente, a maxila através de uma sutura obliqua. O amplo e quadrangular processo do pterigoide descende ventrocaudalmente e forma a margem medial da fenestra orbital inferior. Este processo apresenta ainda um pequeno forame que se abre na fossa orbito-nasal. O pequeno processo maxilar forma, caudalmente, a metade medial da borda rostral da fenestra orbital inferior. O processo maxilar ainda sobrepõe à superfície dorsal da maxila próximo a orbita e contribui para a formação do forame maxilopalatino (Figs. 6 e 7).

Ectopterigóide (Ec) - formam a margem laterocaudal da fenestra orbital ventral. Cada ectopterióide exibe três processos, rostrolateral, laterocaudal e medial. O processo rostrolateral sobrepõe à superfície dorsal da porção caudal da maxila, estendendo-se pelos 
quatro últimos dentes. Lateralmente, estes processos se articulam com a porção caudal da margem ventromedial do processo maxilar do jugal. O processo medial bifurca em ramos dorsal e ventral, que ancoram firmemente a porção rostral do processo transverso do pterigóide. O ramo ventral é vertical e menor que o dorsal. A superfície dorsal do palatino apresenta duas cristas laminares na porção mediana. Rostralmente existe um tubérculo que se torna continuo caudalmente às duas bordas da lamina palatina dorsal, um dobramento que forma as bordas do espaço piriforme, sendo continuas caudalmente no osso pterigoide (Figs. 6 e 7).

Pterigóide (Pt) - correspondem nos maiores elementos da porção caudal do palato e sustentam um dente cada. Formam a borda mediocaudal de cada fenestra orbital ventral e, junto com o parabasesfenóide, a borda posterior do espaço piriforme. Rostralmente apresentam dois processos, o palatino, medialmente e o transverso, lateralmente. Cada processo platino é plano e triangular, forma o quadrante posterior do assoalho da cavidade oral e, dorsalmente é sobreposta pelo processo pterigóide de cada palatino. Cada processo transverso estende-se laterocaudalmente e contatam o quadrado. Este processo se expande e rostralmente é envolvido pelos ramos ventral e dorsal do processo medial do ectopterigóide. Caudalmente cada pterigóide apresenta um longo e lateralmente comprimido processo quadrado, que constitui a metade do tamanho deste osso. O processo quadrado é medialmente côncavo, lateralmente convexo e estende-se laterocaudalmente para articular com a porção ventral do quadrado. O processo transverso apresenta-se como uma lâmina delgada e levemente convexa dorsolateralmente. Na porção média do pterigoide, na base do processo transverso, existe uma projeção ventrolateral ampla que se articula com o ectopeterigóide. Ventralmente contata o parabasisfenóide através de uma ampla superfície. Os pterigoides são os únicos ossos palatais que apresentam dentes. Cada elemento possui uma fileira de pequenos dentes cônicos e retilíneos na face ventral, ao nível da margem caudal da fenestra orbital inferior. Esta fileira direciona-se lateralmente acompanhando a margem óssea que delimita a borda medial da fenestra piriforme, caudalmente (Figs. 6 e 7).

Ossículos da esclera - correspondem em finas placas ósseas que se dispõe em círculo na margem da córnea. Existem 13 placas trapezoides de tamanho similar em cada olho. Individualmente os ossículos apresentam uma flexura sigmoide em sua porção média, limitante à concavidade produzida pelo sulco que acompanha a morfologia da esclera. Os ossículos 1, 3 e 9 são placas (+) devido sua sobreposição e os ossículos 2, 5 e 12 são (-) visto que estão sobrepostos pelas placas vizinhas. As demais placas apresentam uma extremidade sobreposta e outra não (Fig. 8). 


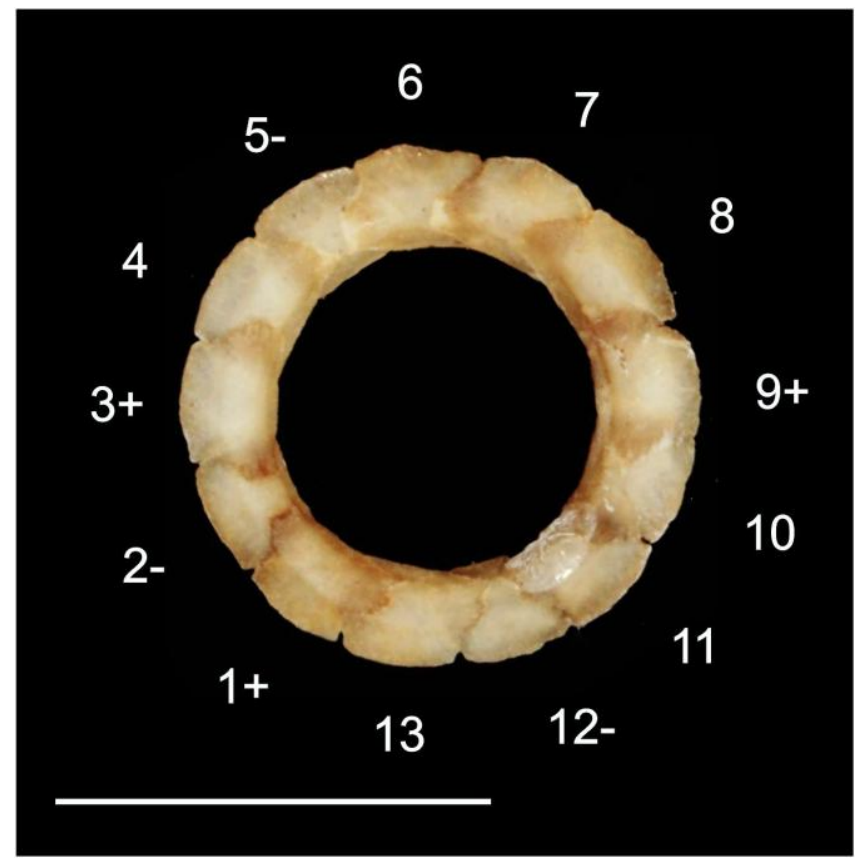

Figura 8: Ossículos da esclera de I. iguana iguana adulta. Barra $1 \mathrm{~cm}$.

Dentário (De) - elemento rostrolateral na mandíbula. É o único elemento da mandíbula que apresenta dentes. Compreende a metade do comprimento total da mandíbula e apresenta 28 dentes fixos em uma superfície alveolar bem definida. O dentário reveste a porção rostrolateral da cartilagem mandibular. Caudalmente o dentário alcança o nível do ápice do coronóide através de uma projeção pontiaguda que se articula em forma de entalhe com o coronóide e suprangular, na vista lateral e ventromedialmente contata o articular. $\mathrm{Na}$ face medial o dentário é bifurcado, o processo esplenial ventral e a porção rostroventral do processo coronóide dorsal sobrepõe o processo lingual rostral do coronoíde. Lateralmente o dentário apresenta cinco ou seis forames mentuais posicionados em série. Medialmente exibe uma alongada projeção triangular que contata obliquamente o esplenial. Rostralmente cada dentário se volta medialmente e contata seu contralateral formando uma sutura que une as duas porções da mandíbula (Fig. 9).

Coronóide (Co) - está localizado imediatamente caudal ao dentário. Ele possui dois processos ventrais largos que se projetam rostral e caudalmente, o processo dentário e o esplenial, respectivamente. Ainda possui um conspícuo processo dorsal, posicionado imediatamente caudal aos dentes mandibulares. Apresenta forma triangular e está posicionado no final do terço médio da mandíbula. Ventrolateralmente o coronóide possui um processo labial que sobrepõe o dentário. Caudal ao processo labial, o coronóide se articula com a 
margem rostral do suprangular. Medialmente o processo esplenial possui uma crista proeminente para inserção muscular (Fig. 9).

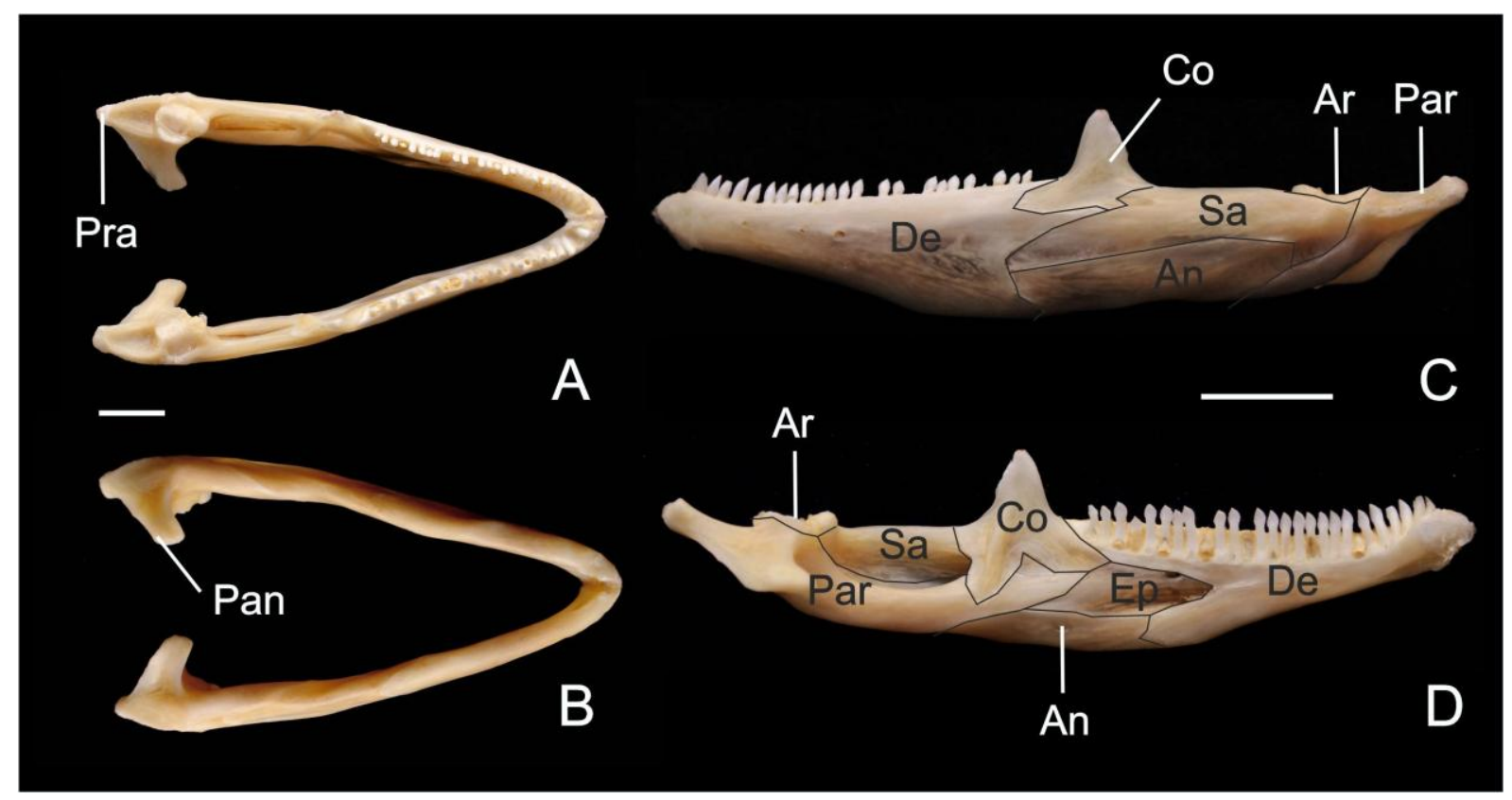

Figura 9: Mandíbula de I. iguana iguana adulta. Vista dorsal (A), ventral (B), lateral (C) e medial (D). De, dentário; Co, coronóide; Sa, suprangular; An, angular; Par, pré-articular; Ar, articular; Ep, esplenial; Pra, processo retroarticular; Pan, processo angular. Barra $1 \mathrm{~cm}(\mathrm{~A}-\mathrm{B})$, $2 \mathrm{~cm}(\mathrm{C}-\mathrm{D})$.

Suprangular (Sa) - ocupa a metade caudal da mandíbula e forma a porção dorsal entre o coronóide e o articular. Existe um forame na face lateral, sendo direcionado caudalmente, próximo à área de contado com o coronóide. Medialmente ele limita a borda dorsal do grande forame mandibular. Em vista lateral, o suprangular possui um terço do tamanho da mandíbula, aproximadamente e possui um processo rostrolateral estreito e alongado que se estende entalhado entre o coronóide e o dentário, dorsal e ventral, respectivamente. A borda ventrolateral articula-se rostralmente com a borda lateral do angular e caudalmente com parte da borda lateral do pré-articular. Caudalmente o suprangular e o préarticular são fundidos assim como as porções ventromedial e caudomedial. A articulação entre este e o pré-articular apresenta uma depressão rasa na parede lateral (Fig. 9).

Pré-articular (Par) - forma a extremidade caudal de cada ramo mandibular e repousa sobre a face ventral e lingual da mandíbula. Caudalmente possui dois processos triangulares, o retroarticular caudal e o processo angular, medialmente. O processo angular compreende em uma conspícua projeção ventromedial. Em vista dorsal o processo 
retroarticular é definido por duas cristas de bordas arredondadas a crista timpânica, lateralmente e, medialmente a crista medial que convergem posteriormente formando um proeminente tubérculo retroarticular. Rostral aos processos angular e retroarticular, a face dorsal é fundida com a sobreposição do articular. A extremidade rostromedial contata a porção ventrocaudal do processo lingual rostral do coronóide. A margem dorsal se articula com a borda ventromedial do suprangular e forma a parede da fossa adutora. O pré-articular articula-se rostroventralmente com o angular e ventrocaudalmente com o suprangular, somente a porção rostral da sutura pré-articular - suprangular é distinguível (Fig. 9).

Angular (An) - ventralmente o angular compreende numa pequena porção do comprimento total da mandíbula e repousa ao longo da face ventral de cada ramo. Sua margem caudal é irregular e articula-se lateralmente com o suprangular e medialmente com o pré-articular. Rostromedialmente o articular se articula com o dentário e com o esplenial, caudomedialmente com o pré-articular. Existe ventromedialmente um pequeno forame, o forame milohioideo caudal (Fig. 9).

Esplenial (Ep) - é o único elemento completamente medial na mandíbula. A metade rostral de sua face dorsal articula-se com o processo lingual coronóide do dentário rostralmente e com a borda ventral do processo lingual rostral do coronóide, caudalmente. A metade caudal de sua borda ventral articula-se com a margem lingual do processo medial do angular. A metade rostral da margem ventral articula-se com a borda dorsal do processo esplenial lingual do dentário. A extremidade rostral do esplenial forma a margem caudal do forame alveolar ventral e ainda possui um forame milohioideo rostral, caudalmente posicionado em relação ao forame alveolar ventral (Fig. 9).

\section{Neurocrânio}

Basioccipital (Bo) - Está posicionado entre as capsulas ópticas e forma a parede caudal da caixa craniana e a porção média do côndilo occipital. Articula-se amplamente com o parabasisfenóide rostralmente e ventralmente contata o parabasisfenóide. Articula-se com o processo ventral do pró-ótico rostrolateralmente e com a crista tuberal do otoccipital laterocaudalmente (Fig. 7).

Supraoccipital (So) - está orientado rostrodorsalmente. Apresenta forma similar a uma sela que repousa caudoventralmente ao parietal e forma a porção caudal do teto do crânio. Sua porção medial forma a borda dorsal do forame magno. A margem ventrolateral articula-se com a margem dorsolateral do processo alar do pró-ótico rostralmente e com a margem ventrocaudal do corpo do otoccipital caudalmente. As faces ventrocaudal e 
dorsocaudal possuem uma depressão, um recesso côncavo orientado rostromedialmente que constitui a metade rostral da bula auditória, a metade anterior é formada pelo otoccipital. Sua porção mais caudal possui duas depressões côncavas lateralmente orientadas. Na porção mediana desta face, uma crista protuberante e delgada separa as referidas depressões. A superfície dorsal contata o parietal e exibe, próximo a linha mediana, dois pequenos tubérculos lateralmente dispostos a crista mediana do supraoccipital (Figs. 6 e 7).

Parabasisfenóide $(\mathbf{P b})$ - A porção dérmica deste elemento é fundida com o basisfenóide e, portanto, indistinguível, exceto por um longo e delgado processo cultriforme rostromedial. Assim, esses ossos são descritos genericamente como um único elemento assim denominado. Ele forma o assoalho do crânio e se articula com o basioccipital caudalmente e com o pró-ótico dorsalmente. Suas bordas ventrolateral e rostrodorsal são formadas pela crista selar transversa. Ele possui três pares de processos em adição ao processo cultriforme. Dois delgados, planos e laterocaudais processos que sobrepõem o basioccipital rostrolateralmente e se estendem na face rostrodorsal até o tubérculo esfenoccipital. Entre as extremidades destes processos, a superfície ventral apresenta um recesso. Rostralmente dois processos basipterigóideos, orientados ventrolateralmente, estão presentes e expandem esta extremidade. Esta porção articula-se com o pterigóide. Dorsal a cada processo basipterigóide existe um pequeno processo alar dorsolateral. As extremidades deste processo e da porção rostral do processo anteroventral do pró-ótico estão aderidos à pila antótica. Lateralmente é perfurado, na base de cada processo caudolateral, por um canal carótico, que percorre a porção ventrolateral na superfície rostral. O delgado e alongado processo cultriforme repousa sobre a trabécula comum e se estende rostrodorsalmente até o ponto correspondente ao limite caudal da maxila, dorsalmente ao espaço piriforme (Fig. 7).

Otoccipital (Ot) - Está fundido ao opistótico, na porção interna do crânio. Estes elementos serão então descritos como únicos. Este forma a parede caudal do crânio e contata o pró-ótico rostrolateralmente, o supraoccipital dorsomedialmente e o basioccipital ventromedialmente. Forma a margem lateral do forame magno e a porção lateral do côndilo occipital. Possuem um processo paraoccipital. A superfície interna deste possui uma depressão côncava em forma de recesso que compreende na metade posterior da bula auditória. Os forames hipoglosso e vagal estão presentes na porção caudal. O processo paraoccipital estende-se laterocaudalmente como um par de barras robustas e quadrangulares. Sua porção lateral apresenta uma pequena dilatação similar a um tubérculo que contata o quadrado, o parietal e o supratemporal. A extremidade lateral de cada processo paraoccipital é sobreposta pela extremidade posterior do supratemporal rostralmente, o processo 
supratemporal do parietal dorsalmente e a cartilagem intercalar ventralmente. O esquamosal também contata discretamente este. Rostral ao processo paraoccipital, cada otoccipital possui um recesso jugular. Caudalmente exibe uma crista tuberal, que possui lateralmente um forame hipoglosso ventral. Esta porção do otoccipital ainda possui três forames hiploglosso juntamente dispostos com o forame vagal (Figs. 6 e 7).

Pró-ótico - posicionados na parede rostrolateral do crânio possui, cada um apresenta três processos, o processo alar, o rostroventral e o dorsocaudal. O processo alar é pequeno e rostrodorsalmente orientado com a margem lateral do supraoccipital, caudalmente. A margem rostral do processo alar forma a crista alar. O processo rostroventral articula-se com o parabasisfenóide rostralmente e com o basioccipital ventralmente. Este possui ventralmente uma ampla cavidade perfurada pelo forame facial. A margem lateral deste processo forma a metade anterior da crista pró-ótica. O processo dorsocaudal sobrepõe a superfície rostral do processo paraoccipital do otoccipital e a margem medial forma a margem anterior da fenestra oval. Este recesso forma o assoalho e a parede medial da cavidade timpânica.

\section{Viscero-crânio}

Quadrado (Qu) - localizado em cada uma das porções laterais do crânio, articulando-se e sustentando a mandíbula. Para tal, ventralmente exibe uma ampla área articular similar a um côndilo quadrangular que se articula com as porções medial e lateral da fossa glenóide do articular. Este apresenta duas saliências proeminentes e uma área media côncava. Caudalmente o quadrado apresenta uma crista caudal que divide o osso em duas amplas e côncavas fossas. A face rostral é ampla, plana e levemente curvada medialmente formando uma delgada placa óssea. A metade medial de cada quadrado articula-se com o processo quadrado do pterigóide ventromedialmente. A metade lateral exibe um forame quadrado rostral. Dorsalmente exibe um pequeno tubérculo rostral e um amplo côndilo cefálico caudal, ambos se articulam com o esquamosal. Entre estas proeminências existe uma incisura rasa que também contata o esquamosal. Ventrocaudalmente este contata o processo transverso do pterigoide (Figs. 6 e 7).

Epipterigóide (Ep) - possui forma de um longo e delgado bastão que se posiciona verticalmente entre o palato e o crânio, similar a dois pilares. Eles estão dorsocaudalmente inclinados estendendo-se dorsalmente tocando a borda ventrolateral do processo ventral do parietal e a face dorsolateral do pterigóide. Ambas as extremidades apresentam uma pequena dilatação similar a um maléolo (Fig. 6). 
Articular (Ar) - representa o único elemento endocondral da mandíbula. Ocupa a porção mais caudal do ramo mandibular. Está localizado entre a porção rostral do processo retroarticular e do processo angular do pré-articular, com o qual é fundido. Rostralmente é também fundido com o angular. Apresenta um rostrodorsal, um laterocaudal e outro caudomedial. Exibe um par de concavidades dorsais, as porções medial e lateral da fossa glenóide, que formam a faceta articular da mandíbula, que se articula com o osso quadrado. Exibe uma porção na fossa adutora e outra na porção final do canal mandibular (Fig. 9).

Aparato hióide - situado abaixo da mandíbula suporta os músculos linguais, da faringe e a porção cranial da traqueia. É composto por um elemento basihial, que forma a estrutura do corpo do hióide e três pares de arcos viscerais. Esta estrutura é alongada e composta por dois elementos cilíndricos e rostralmente contínuos com dois delgados processos, o glossohial. O primeiro par de arcos viscerais está conectado laterocaudalmente ao basihial. É composto por um longo elemento ceratohial curvado rostralmente cuja extremidade distal apresenta um discreto côndilo. O segundo par de arcos viscerais está localizado caudalmente, continuo ao basihial. Cada arco é formado por uma pequena barra, o ceratobranquial. Estes estão direcionados lateralmente formando um pequeno ângulo entre ambos os elementos. O terceiro par está fixado na porção mais caudal do ceratobranquial sendo quase contínuo, lateralmente com esta porção. O ceratohial é o único elemento completamente ossificado, os demais elementos apresentam calcificação com uma delgada camada de cartilagem remanescente (Fig. 10).

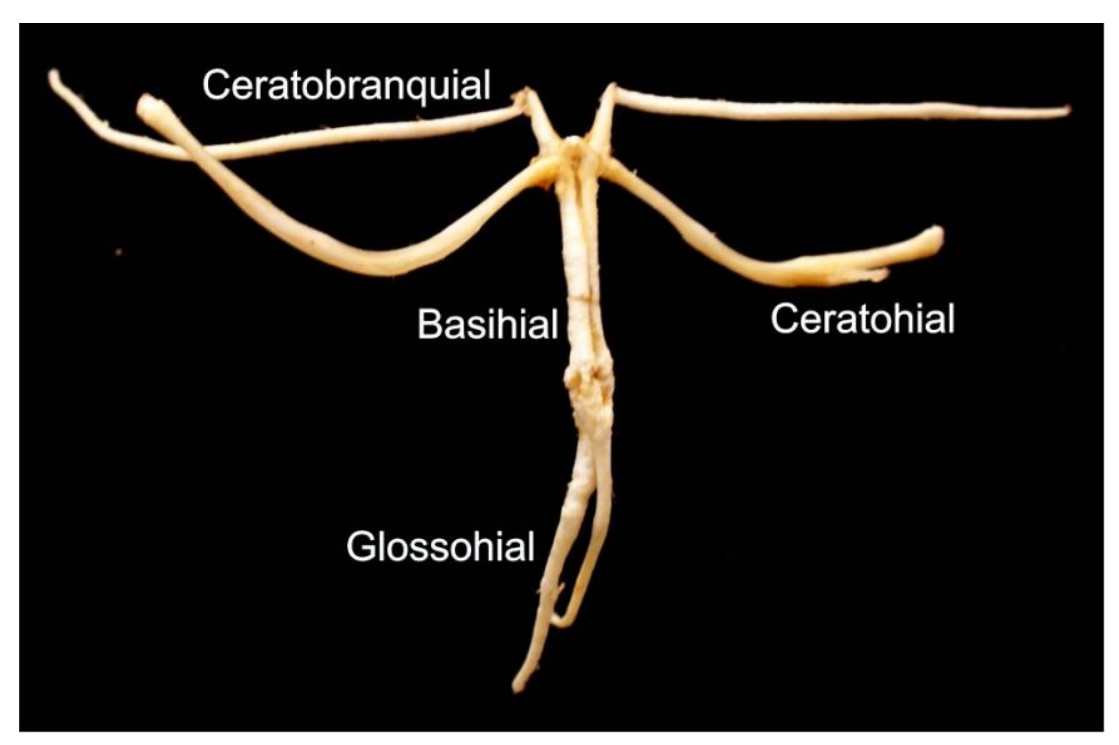

Figura 10: Aparelho hióide de I. iguana iguana adulta. 


\section{Vértebras}

As vértebras de I. iguana iguana são divididas nos segmentos cervical, dorsal, lombar, sacral e caudal. Tipicamente apresentam um centro (corpo) vertebral e um arco vertebral de onde se projetam processos. O processo espinhoso esta localizado dorsalmente e assume dimensões variadas de acordo com o segmento. Um par de processos articulares cranial e outro par de processos articulares caudais estão presentes. Nos segmentos sacral e caudal existem costelas que se fundiram a estrutura do corpo vertebral. As vértebras caudais apresentam ainda um afilado processo hemal, ventralmentente (Fig. 11).

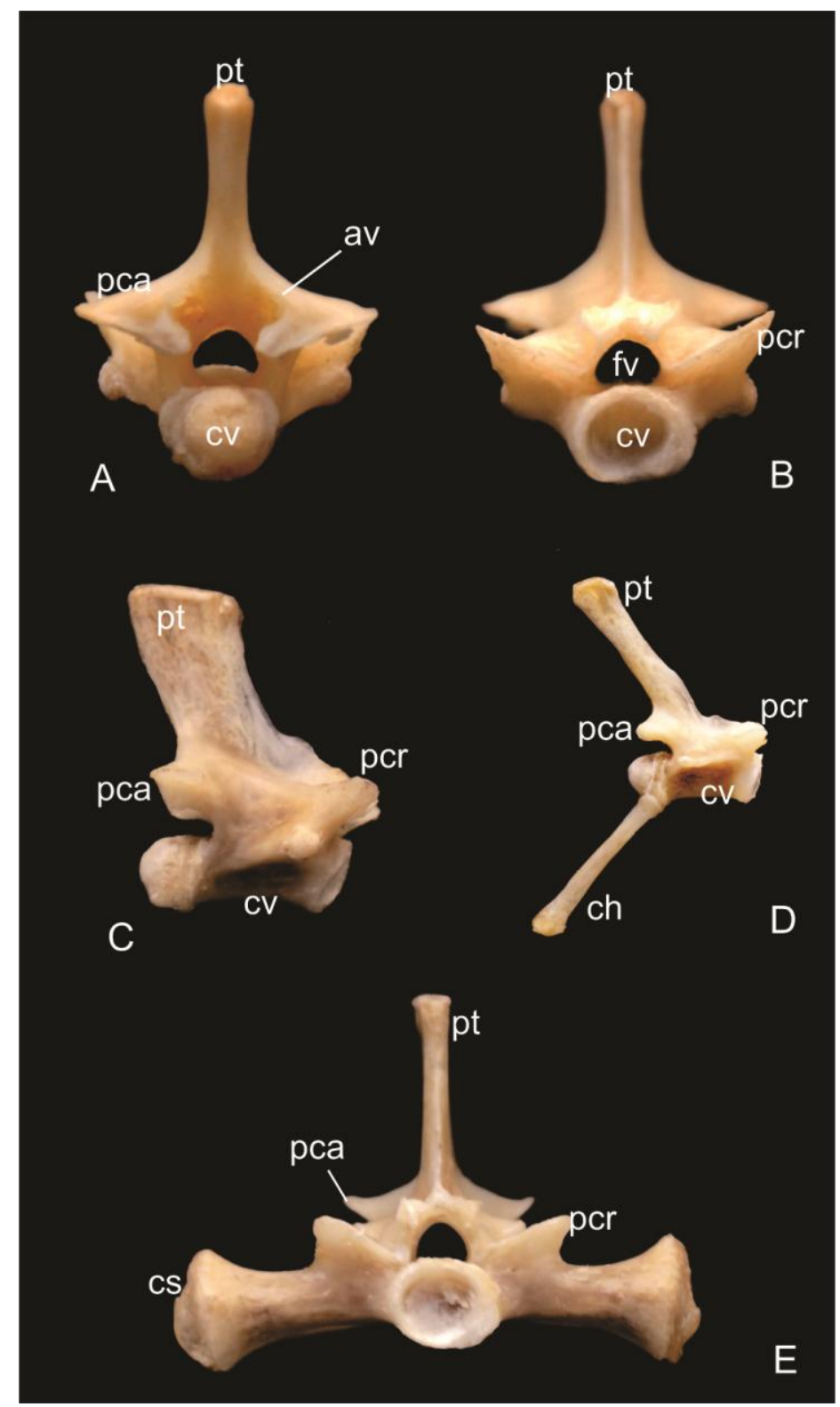

Figura 11: Vértebras de I. iguana iguana adulta. A-C segmento dorsal; D, segmento caudal e E segmento sacral. av, arco vertebral; cv, centro vertebral; ch, processo hemal; cs, costela sacral; fv, forame vertebral; pca, processo articular caudal; pcr, processo articular cranial; pt, processo transverso. 
Vértebras cervicais - As vertebras cervicais típicas possuem um corpo bem definido, assim como extremidades cranial e caudal côncava e convexa, respectivamente e ainda onze processos. A superfície articular caudal corresponde em um côndilo articular.

O corpo vertebral é quadrangular embora em vista ventral seja ligeiramente subtriangular devido ao estreitamento caudal da face articular em relação a largura da projeção cranial dos tubérculos laterais. Ventralmente o corpo exibe uma linha larga e lisa que se estende longitudinalmente. O forame vertebral é típico e arredondado formado ventralmente pelo corpo e dorsolateralmente pela lâmina vertebral.

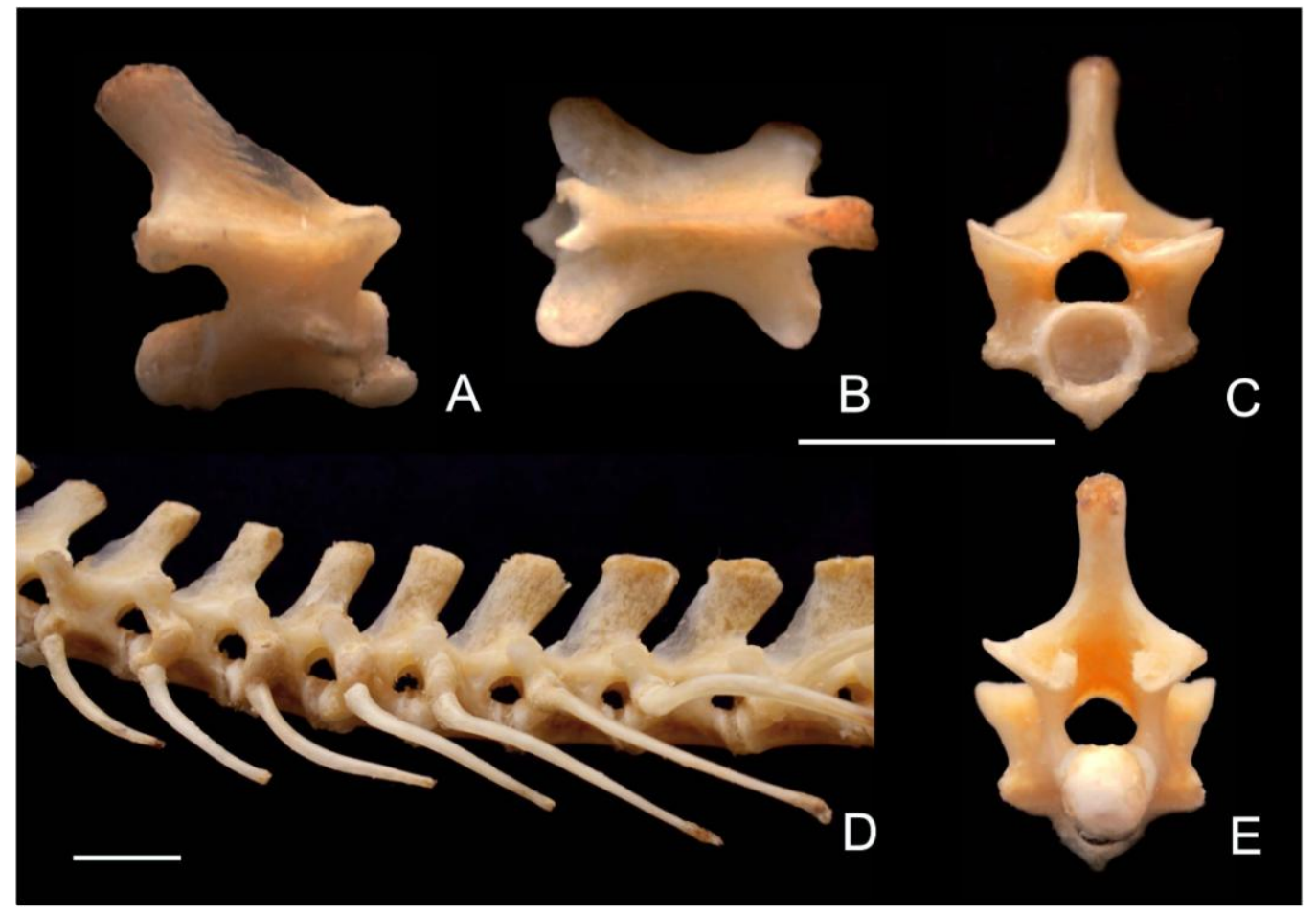

Figura 12: Vértebras cervicais de I. iguana iguana adulta. Vista lateral (A, D), dorsal (B), cranial (C) e caudal (E). Vista lateral, em posição anatômica, do segmento cervical com suas respectivas costelas (D). Barra $1 \mathrm{~cm}$.

Cranialmente são identificados três pares de processos, todos eles articulares. Posicionado craniolateralmente o processo articular cranial é levemente projetado dorsalmente. Sua superfície articular é ligeiramente côncava e voltada dorsomedialmente. Medialmente localizados, um par diminuto de processos estão presentes, os processos articulares craniais medianos se articulam com os processos caudais medianos. A porção mais lateral do corpo da vertebra possui uma grande massa óssea romboide e alongada no sentido dorsoventral. Representam um processo condilar para articulação com as costelas cervicais (Fig. 12). 
$\mathrm{Na}$ porção caudal estão presentes dois pares de processos articulares. O processo articular caudal é lateral e ligeiramente orientado. Apresenta uma face articular plana, oval e direcionada lateromedialmente. A face medial deste processo abriga ainda uma pequena projeção que corresponde no processo articular caudal mediano.

A partir da superfície dorsal do corpo vertebral se projeta o conspícuo processo espinhoso. Corresponde na metade da altura total da vértebra e possui forma triangular, sendo sua porção caudal mais larga.

Ventralmente localizado sobre a articulação entre o côndilo vertebral caudal e a superfície articular cranial existe um pequeno processo ventral. Trata-se de uma ossificação independente que repousa sobre a superfície ventral na região cervical. Possui forma de losango e uma pequena crista na porção mediana.

\section{Atlas}

Apresenta morfologia bem distinta das demais vertebras, inclusive do segmento cervical. Não apresenta processos bem definidos ou um corpo vertebral. É constituído por três estruturas distintas que se contatam e contribuem para sua formação; dois arcos neurais e um intercentro. Cada arco neural está localizado dorsolateralmente e se articulam dorsalmente, formando e fechando esta porção do arco vertebral do atlas. Embora seja cada arco neural uma peça única, é possível observar que este é constituído de duas porções. Uma lâmina quadrangular larga e delgada, dorsalmente, que unida a sua contralateral assume a forma de “ $\Lambda$ ”. A porção lateral é robusta, larga e mais espessa, apresentando uma pequena faceta articular côncava de margens bem marcadas e que contribui na articulação com o côndilo occipital. Entre estas duas porções existe uma crista discreta que finda caudalmente num tubérculo dorsal. Este exibe ainda outro pequeno tubérculo caudal (Fig. 13).

$\mathrm{O}$ intercentro constitui de uma pequena lâmina curvada ventralmente que aloja o processo odontóide do áxis. Cranialmente exibe uma face articular côncava que completa a superfície articular para o côndilo occipital. Esta superfície articular completa possui forma de U. Existe um processo ventral curto e laminar que se direciona caudalmente na face ventral do intercentro.

Caudalmente a porção lateral do arco neural e o intercentro também exibem faces articulares côncavas que se unem para formar uma extensa área articular em forma de U que contata e aloja o processo odontóide do áxis. O comprimento do atlas corresponde em aproximadamente um terço da altura total deste. Entre as lâminas dorsais do atlas e o processo 
odontóide do áxis posicionado ventralmente existe a abertura do forame vertebral que é largo e triangular.

\section{Áxis}

Embora seja diferenciada das demais vértebras cervicais, representa uma vértebra típica. A maior parte das estruturas presentes é similar as demais cervicais, exceto pelo processo odontóide e pela característica um pouco distinta do processo espinhoso (Fig. 7).

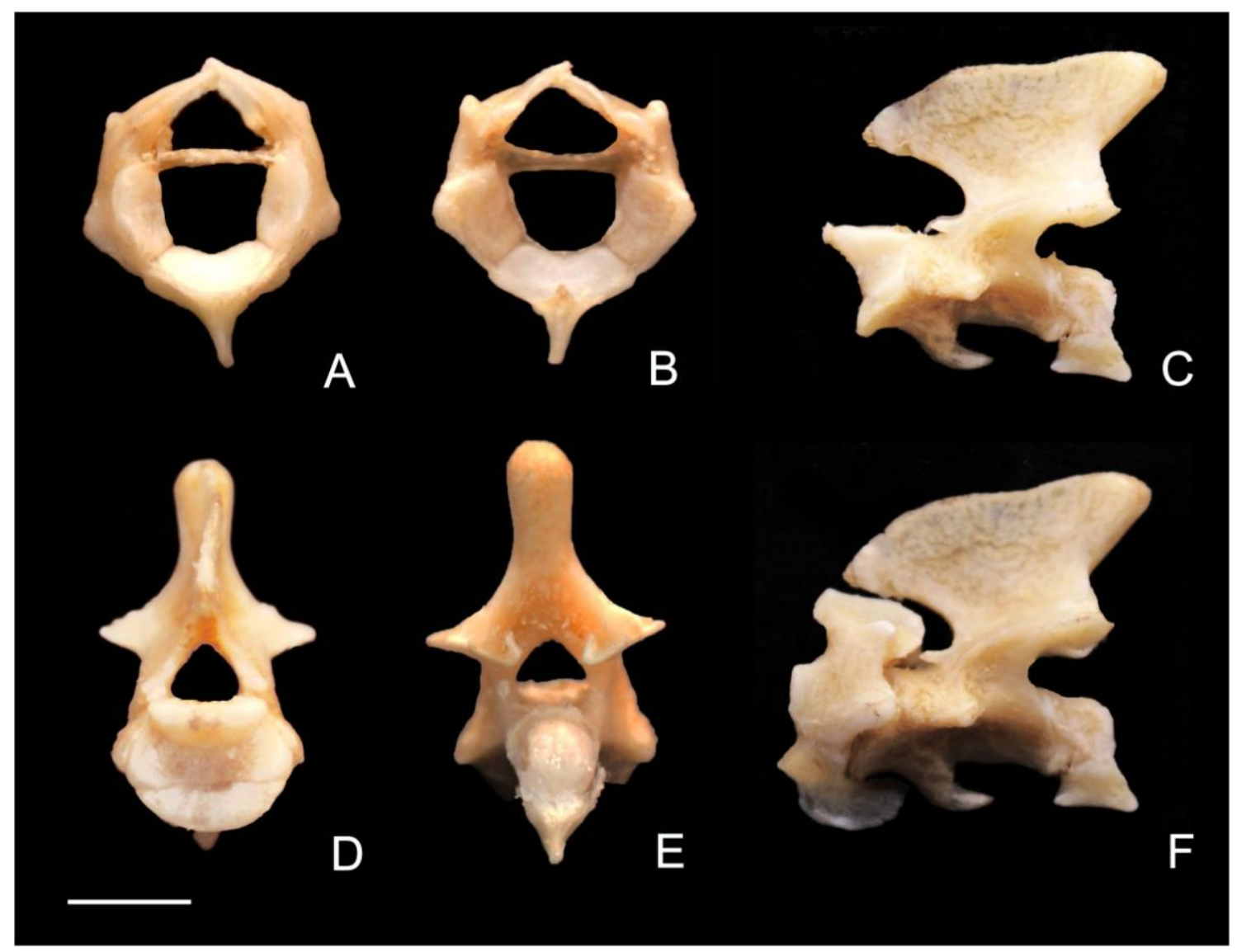

Figura 13: Vértebras cervicais de I. iguana iguana adulta. Atlas, vista cranial (A) e caudal (B). Áxis, vista lateral (C), cranial (D) e caudal (E). Vista lateral das duas primeiras vérterbras cervicais em posição anatômica (F). Barra $1 \mathrm{~cm}$.

O corpo vertebral é alongado devido a presença cranial de uma massa óssea conspícua que corresponde no processo odontóide, que repousa sobre o intercentro do atlas, entre as porções laterais dos arcos neurais. Este processo é grande, quadrangular e apresenta uma projeção cranial que marca uma área côncava na porção mediana do elemento e que se articula com a porção caudal do atlas. Está fundido ao corpo vertebral através de uma sutura bem marcada e retilínea. Sua superfície dorsal é plana e fecha o assoalho do forame vertebral 
do atlas, onde está fixado por meio de uma faixa larga de tecido conjuntivo que constitui em um forte ligamento. Ventralmente contata o processo ventral.

Não existe processo articular cranial, apenas o caudal que é largo, apresenta face articular voltada ventalmente e se origina na base do processo espinhoso, limitando a incisura vertebral caudal. O corpo exibe uma face articular caudal bem proeminente e esférica. A lâmina vertebral é delgada e limita as paredes laterais do forame vertebral, que assume contorno sub-triangular. Da porção dorsal da lâmina forma-se o processo espinhoso largo e laminar direcionado caudalmente, exibindo duas projeções cônicas, uma delgada, cranial e outra rombóide, caudal.

Vértebras dorsais - Este segmento compreende onze vértebras com morfologia similar e sem variação entre os segmentos cervical e lombar. O corpo vertebral exibe morfologia idêntica as últimas vertebras cervicais, inclusive com a presença de um pequeno tubérculo articular costal lateral, que neste segmento contata a cabeça das costelas dorsais.

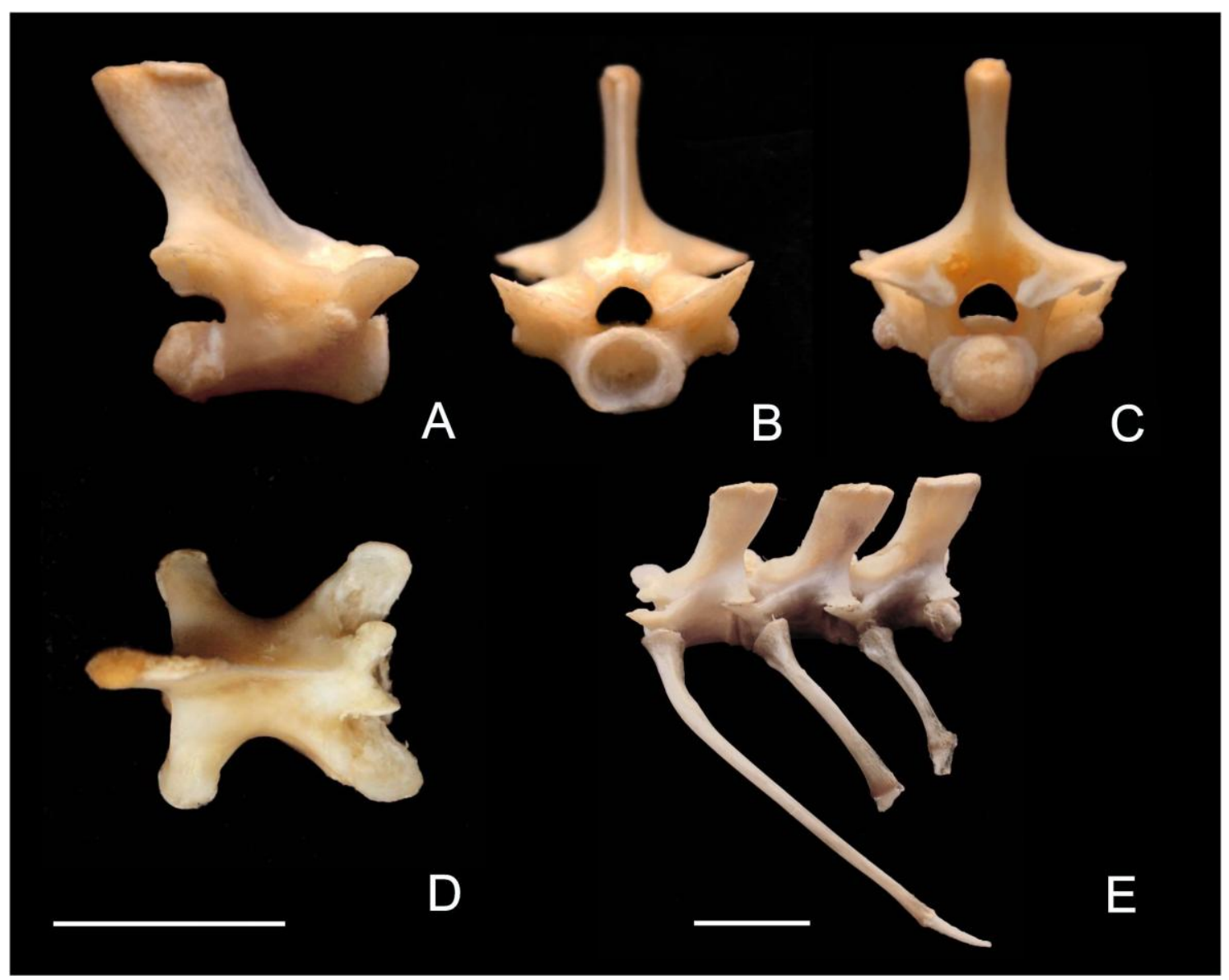

Figura 14: Vértebras dorsais de I. iguana iguana adulta. Vista lateral (A), cranial (B), caudal (C) e dorsal (D). Vértebras dorsais D12, D13 e D14 e suas respectivas costelas em vista lateral (E). Barra $1 \mathrm{~cm}$. 
De maneira geral estas são ligeiramente mais longas que as vértebras do segmento cervical. Seus processos articulares cranial e caudal também são mais proeminentes. Ambos bem pronunciados e com faces articulares planas e amplas. Os pares de processos articulares cranial mediano e caudal mediano exibem forma análoga aqueles presentes na porção cervical (Fig. 14).

O processo espinhoso é largo e robusto, direcionado dorsocaudalmente. Apresenta um espessamento na extremidade dorsal que oferece superfície de inserção para alguns ligamentos. Sua borda cranial é laminar e delgada, estendendo-se até a base do processo articular cranial mediano. As vértebras deste segmento também não possuem processo transverso. O tamanho do forame vertebral é compatível com os segmentos adjacentes, apresentando contorno ligeiramente sub-triangular.

Vértebras lombares - São estruturas robustas e características. O corpo é cilíndrico como as demais e apresenta uma fossa arredondada e profunda cranialmente e um côndilo esférico caudalmente. Dois pares de processos articulares craniais, sendo um lateral mais desenvolvido com face articular voltada dorsoventralmente e outro processo mais discreto, mediano e com faces articulares voltadas lateroventralmente.

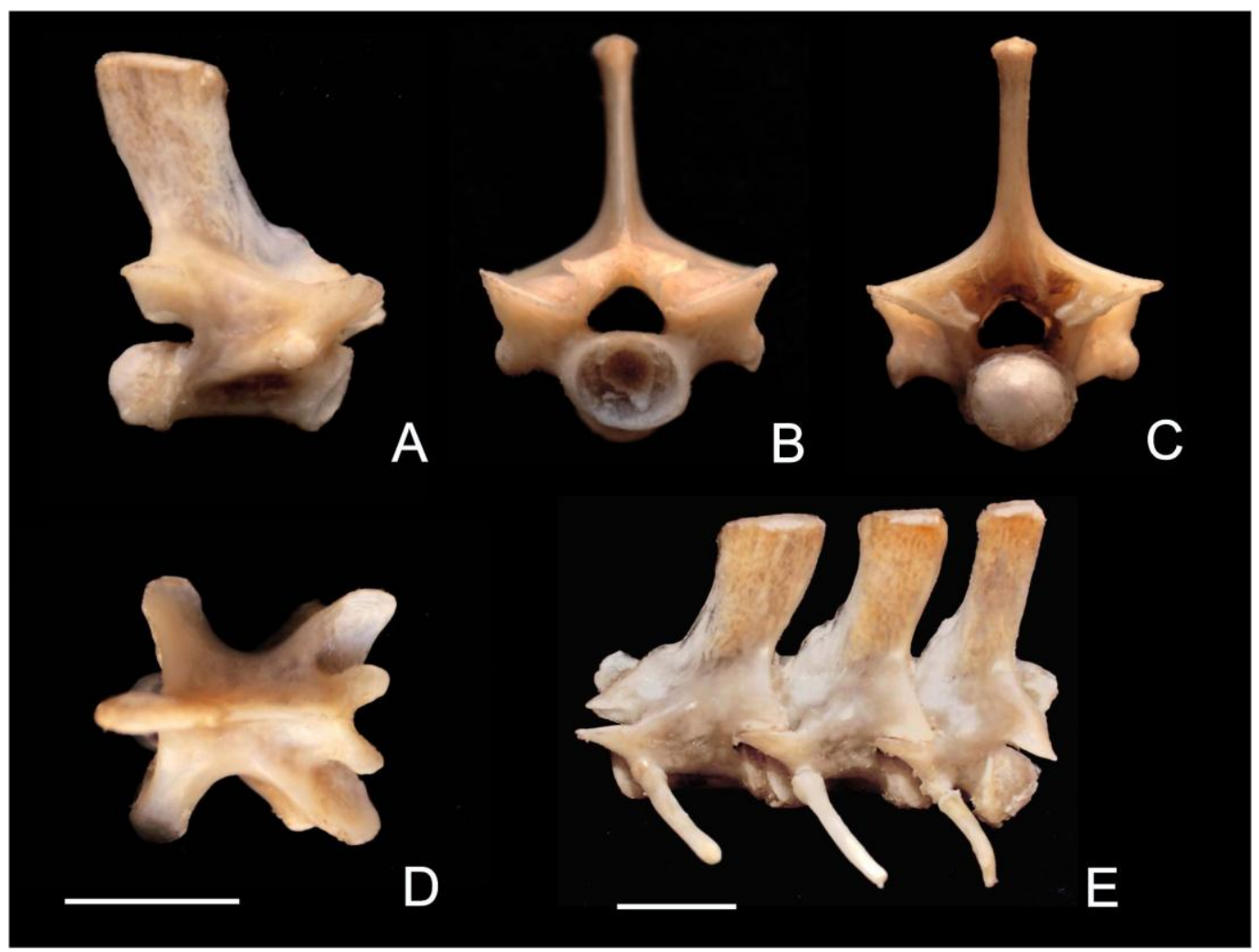

Figura 15: Vértebras lombares de I. iguana iguana adulta. Vista lateral (A), cranial (B), caudal (C) e dorsal (D). Vista lateral, em posição anatômica, das vértebras do segmento lombar e suas respectivas costelas (E). Barra $1 \mathrm{~cm}$. 
O processo articular caudal projeta-se lateralmente da porção dorsal do pedículo, limitando a incisura verterbral caudal. Sua face articular ventral, discretamente direcionada lateralmente. Da margem medial deste destaca-se o processo articular caudal mediano, com face articular diminuta, côncava e lateroventralmente direcionada (Fig. 15).

No corpo vertebral, ventral ao processo articular cranial existe uma crista obliqua finda no pequeno e esférico tubérculo costal lombar. $\mathrm{O}$ forame vertebral apresenta contorno sub-triangular. $\mathrm{Na}$ superfície dorsal do corpo vertebral está presente o robusto processo espinhoso. Este é largo e laminar, compreendendo na metade da altura da vértebra. É ligeiramente direcionado caudalmente, mas sua largura e orientação diminuem gradativamente até a ultima vértebra lombar.

Vértebras sacrais - Apenas duas vértebras sacrais estão presentes em I. iguana. Apresentam morfologia similar aos segmentos aos quais estão relacionadas (lombar e caudal: porção cranial), com algumas exceções. Seu corpo é bem marcado, embora seja consideravelmente menor, tendência já expressa pela última vértebra lombar. O corpo vertebral consiste em aproximadamente um terço de sua altura total. As faces articulares cranial e caudal do corpo não apresentam morfologia diferenciada daquela presente no segmento lombar (Fig. 16).

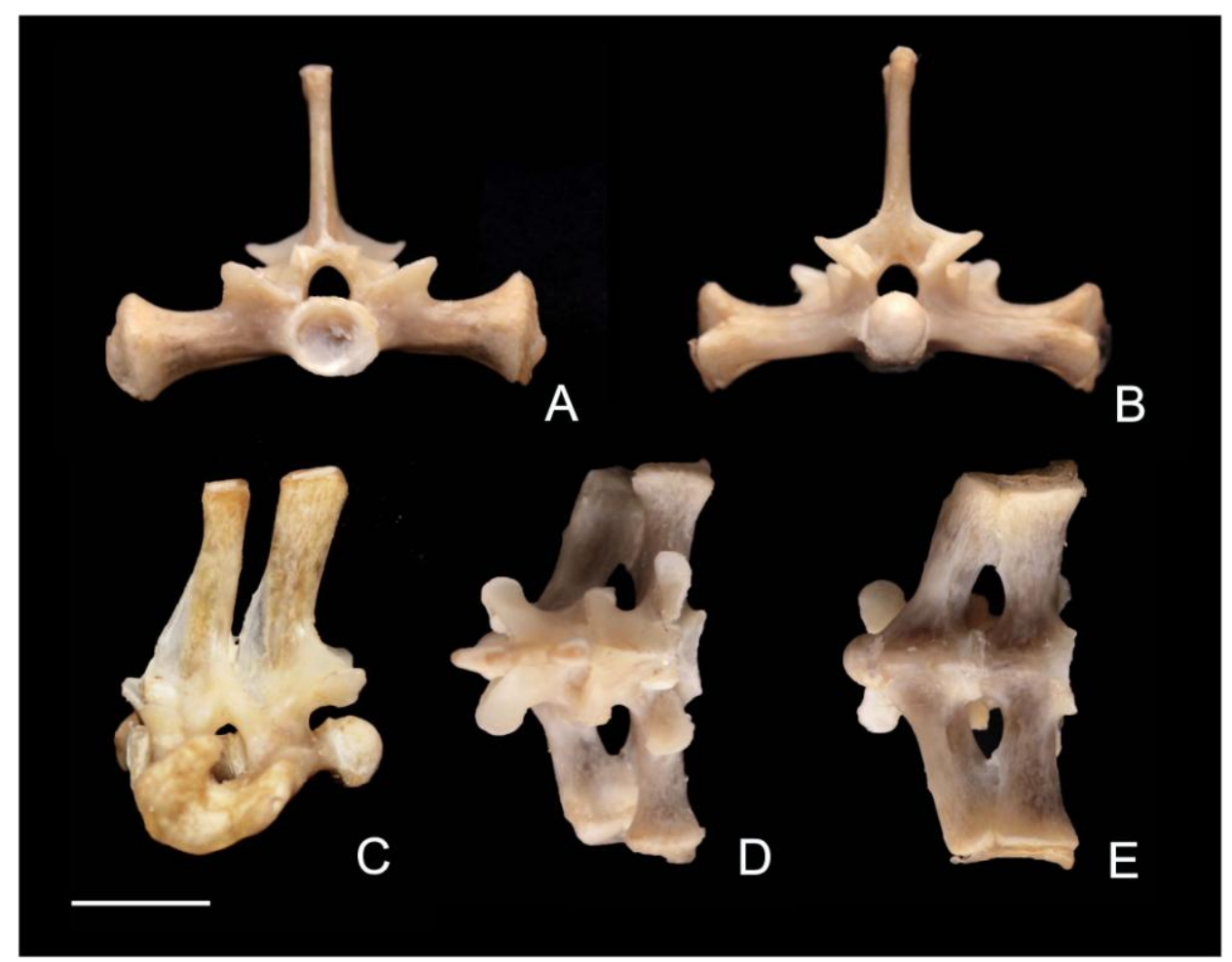

Figura 16: Vértebras sacrais de I. iguana iguana adulta. Vista cranial (A), caudal (B), lateral (C), dorsal (D) e ventral (E). Barra $1 \mathrm{~cm}$. 
Aqui não existe tubérculo para articulação com nenhum elemento lateral. Neste local uma grande e robusta projeção destaca-se do corpo de cada vértebra. São laterais e discretamente orientados ventralmente, estando unidos por meio de uma sutura em sua porção lateral. Assume a forma semelhante a um processo transverso, ou costela sacral, ainda a ser investigado pela ontogenia. A primeira vértebra sacral exibe um processo mais robusto, largo e aparentemente forte que se expande lateralmente e forma uma face articular ampla e semilunar, com a concavidade voltada caudalmente. A segunda vértebra projeta esta extensão cranialmente em direção a primeira vértebra, com a qual faz contato pela extremidade lateral. A referida projeção possui forma mais retilínea e uma superfície articular menos pronunciada que contribui com um quarto para a formação da face articular com o osso ilíaco. Entre ambos os processos existe um espaço que limita uma fenestra sacral de cada lado. A superfície óssea ventral é lisa e a dorsal marcada por pequenas ranhuras.

O forame vertebral no segmento sacral é conspícuo e arredondado. Na porção mais dorsal da lâmina está presente um longo, retilíneo e vertical processo espinhoso que, na segunda vértebra, alcança a porção mais alta no segmento caudal da coluna vertebral. Dois pares de processos articulares craniais e mais dois pares caudais estão presentes, sendo bem semelhantes aos descritos no segmento lombar. Próxima a base do processo transverso da segunda vértebra existe um pequeno forame obliquamente direcionado no sentido dorso ventral.

Vértebras caudais - Existem entre sessenta e setenta vértebras caudais que possuem morfologia diferenciada em sentido craniocaudal. As primeiras vértebras são grandes e morfologicamente similares às vértebras sacrais, sofrendo uma transição no sentido caudal onde estas perdem alguns acidentes ósseos e alteração no padrão de vértebra típica. $\mathrm{O}$ tamanho das vértebras apresenta uma redução conspícua no sentido crânio-caudal. Visto tais características, aqui vamos relatar as três principais morfologias presentes no segmento caudal (Fig. 18).

Vértebras caudais: parte cranial - apresentam estrutura vertebral típica; corpo, lâmina e processos. As treze primeiras vértebras caudais possuem o corpo vertebral cilíndrico com uma depressão profunda e circular cranialmente e uma projeção esférica caudalmente. Esta porção exibe ainda dois pequenos tubérculos hemais ventralmente posicionados que se articulam com as extremidades dorsais do processo hemal. Na transição entre o corpo e a lâmina vertebral projeta-se o proeminente, plano e lateralmente localizado processo transverso. Trata-se de uma projeção uniforme que se direciona caudalmente e possui uma extremidade quadrangular lisa. Dorsalmente do corpo projeta-se o conspícuo processo 
espinhoso. Este representa aproximadamente dois terços da altura da vértebra. Compreende lâmina quase vertical, discretamente orientada caudalmente. Possui uma lâmina delgada na base que torna-se mais espessa em seu ápice, findando em uma discreta borda de face arredondada que oferece área para inserção ligamentar. Cranialmente ao processo espinhoso estas ainda exibem uma delgada e pontiaguda espinha projetada dorsalmente (Figs. 17 e 18).

Quatro pares de processos articulares garantem a articulação entre estes elementos vertebrais. O processo articular cranial apresenta faces laterais levemente convexas e a superfície articular discretamente côncava, voltada dorsomedialmente. Na base cranial do processo espinhoso o par de pequenos processos articulares craniais medianos está presente. Suas faces articulares são côncavas e lateroventralmente dispostas.

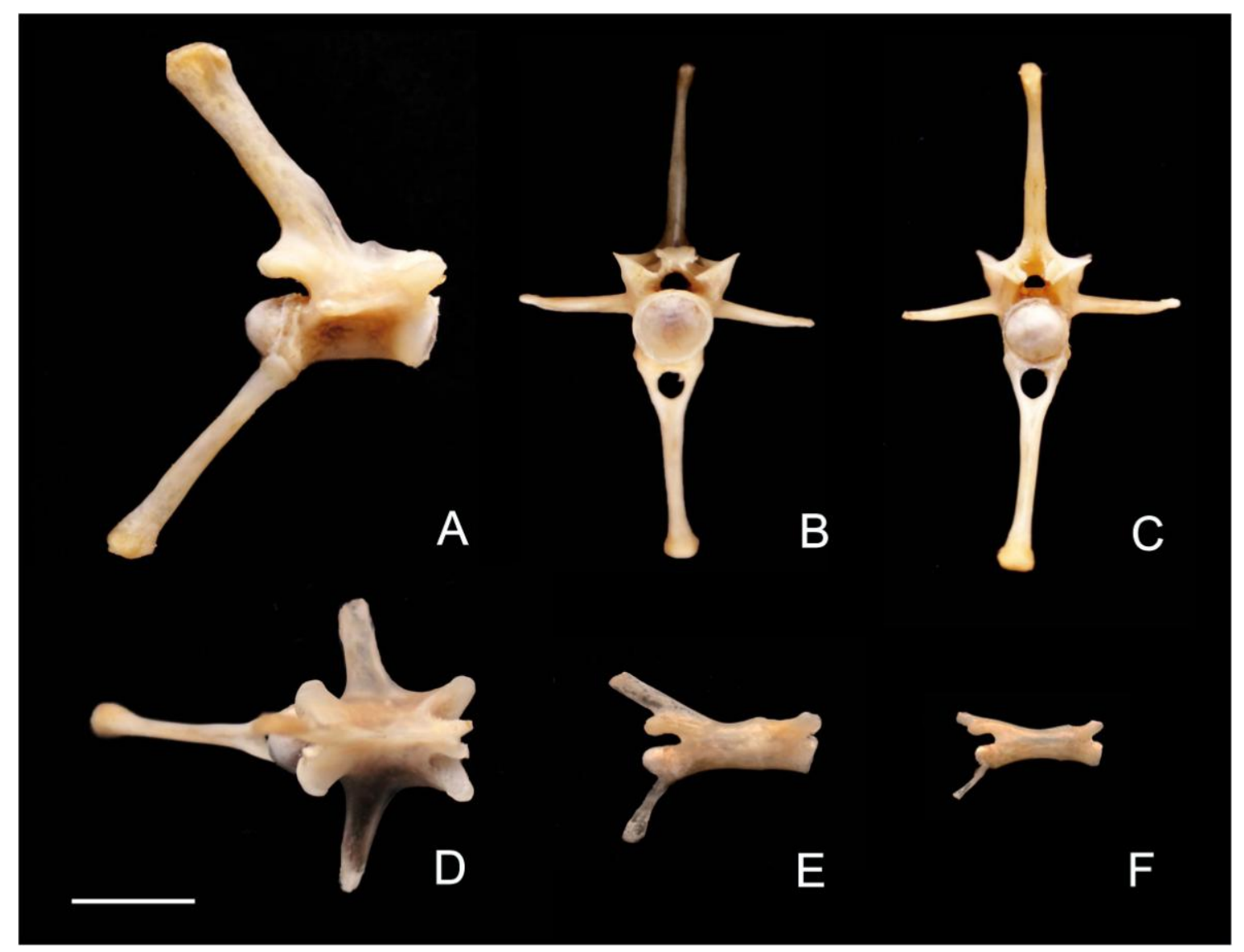

Figura 17: Vértebras caudais de I. iguana iguana adulta. Porção cranial em vista lateral (A), cranial (B), caudal (C) e dorsal (D). Vértebra caudal da porção média (E) e porção caudal (F). Barra $1 \mathrm{~cm}$.

$\mathrm{Na}$ porção caudal outros dois pares de processos articulares, muito similares aos craniais, estão presentes. O processo articular caudal projeta-se entre a base caudal do processo espinhoso e o limite dorsal do pedículo vertebral, limitando a incisura vertebral 
caudal. O processo possui face articular ventrolateralmente posicionada e um par de projeções medianas que também possuem superfície articular, esta voltada medialmente, o processo articular caudal mediano. O forame vertebral é arredondado e típico.

Ventralmente existe um pronunciado processo hemal, independente e que se articula com o par de tubérculos hemais na porção caudal do corpo vertebral. O processo hemal possui forma de Y. Sua projeção ventral é longa e delgada, direcionada caudalmente. Representa aproximadamente três quartos do comprimento total da estrutura. O outro quarto restante representa a bifurcação do processo, formando um espaço entre as duas barras delgadas que, ao se articularem com o corpo vertebral, forma o forame hemal, de aparência oval.

Vértebras caudais: porção média - as próximas trinta e duas vértebras apresentam características anatômicas similares, diferenciando-se das anteriormente descritas. Possuem corpo vertebral alongado e achatado látero-lateralmente e um forame vertebral comprimido dorsoventralmente e bastante reduzido que, no sentido crânio-caudal, torna-se menor (Figs. 17 e 18).

As superfícies articulares do corpo com as demais vértebras são bastante similares entre as diferentes porções do segmento. Os processos articulares tornaram-se menos pronunciados. Dois pares destes processos ainda estão presentes em cada extremidade do corpo, e com características similares as demais vértebras. O processo espinhoso é uniforme e delgado, direcionado caudalmente. A extremidade ventral do corpo vertebral também apresenta pequenas facetas para articulação com o processo hemal, que apenas é menor.

A principal diferença é a ausência do processo transverso. Na porção cranial do corpo existe apenas uma discreta crista na face lateral.

Vértebras caudais: porção caudal - as vinte e uma vértebras finais deste segmento são anatomicamente bem distintas em relação àquelas descritas na porção cranial. Seu corpo é basicamente alongado, quase semelhante a uma falange, exceto pelas extremidades que ainda apresentam alguns processos. As faces articulares do corpo das vértebras são similares às demais, côncava e convexa cranial e caudal, respectivamente (Figs. 17 e 18).

Existe um pequeno par de processos articulares craniais. Estes são direcionados dorsalmente e suas faces articulares verticais e voltadas medialmente. Na extremidade caudal projeta-se caudalmente o processo espinhoso, curto e largo, que aloja o par de processos articulares caudais. Sua face articular é voltada lateralmente e finda no mesmo nível da face articular caudal do corpo vertebral. O forame vertebral é igualmente reduzido e apresenta contornos arredondados, estando presente até a penúltima vértebra. As vértebras desta porção também não apresentam processo transverso. A forma do processo hemal é preservada, mas 
como as demais estruturas, seu tamanho sofre redução. As últimas doze vértebras são desprovidas de processo hemal.

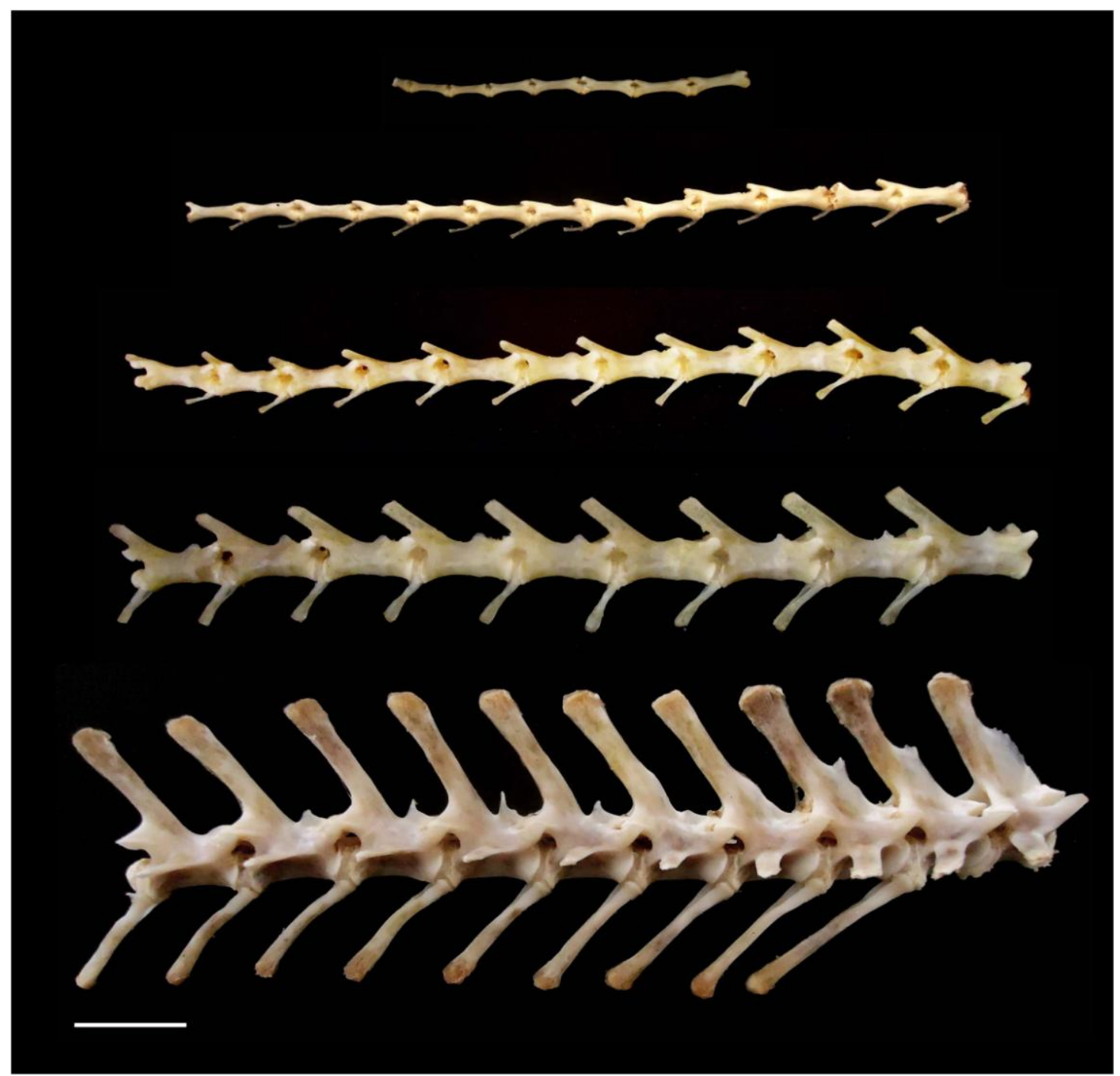

Figura 18: Vista lateral das vértebras do segmento caudal de I. iguana iguana adulta. Barra $1,5 \mathrm{~cm}$.

\section{Costelas}

Costelas cervicais - Existem sete costelas cervicais em I. iguana iguana. A morfologia não apresenta alterações características entre elas ou mesmo em relação aos demais segmentos, exceto pelo tamanho, basicamente. São no geral estruturas alongadas e curvadas craniolateralmente. Apresentam um corpo cilíndrico com a extremidade livre levemente pontiaguda e com a presença de uma pequena barra de cartilagem, que pode ser maior quanto mais caudal é a costela, sendo a última costela cervical três vezes maior que a primeira (Fig. 12D). 
Para articulação com o tubérculo costal da vértebra, as costelas possuem na cabeça uma pequena superfície articular arredondada e levemente côncava. A extremidade livre exibe uma discreta superfície articular plana que contata a cartilagem costal. Entre o corpo e a cabeça existe uma curvatura mais pronunciada que forma um leve ângulo. Toda extensão do corpo é lisa e sem impressões, ranhuras ou forames.

Costelas dorsais - São sete costelas que contatam a cartilagem esternal direta ou indiretamente e mais quatro estruturas livres na porção caudal do segmento vertebral dorsal. As sete primeiras apresentam forma e tamanho similar. O corpo é alongado, correspondendo a metade da parede lateral da 'caixa torácica'. Estão diretamente articuladas com o tubérculo costal das vertebras dorsais e direcionadas caudalmente, contatando a cartilagem costal na porção ventrolateral. Não apresentam impressões ao longo do corpo e suas extremidades são levemente dilatadas (Figs. 14E e 19).

A cabeça da costela dorsal é pequena e exibe um platô circular com bordas pouco pronunciadas e uma rasa concavidade que se articula com o tubérculo costal. Existe um colo discreto entre a cabeça e o corpo. Nesta porção o corpo curva-se caudalmente formando um ângulo conspícuo com relação à cabeça da costela. A extremidade esternal exibe uma dilatação alongada que possui uma superfície articular plana e sub-quadrangular para a cartilagem costal.

Estas primeiras costelas descritas possuem cartilagem costal que contata a cartilagem esternal. As referidas estruturas são alongadas, cilíndricas, de calibre uniforme e apresentam uma curvatura caudal. Estão dispostas na porção lateroventral, limitando esta face da 'caixa torácica'. As quatro primeiras cartilagens costais contatam diretamente a cartilagem esternal, que exibe fóveas articulares com tal finalidade. Quinta e sexta costelas dorsais apresentam cartilagem costal similar as já descritas, porém seu contato com a cartilagem esternal ocorre por meio de uma barra cartilagínea única e mais espessa na porção ventrocaudal da cartilagem, paralelo a linha mediana. O último par de costelas dorsais também apresenta cartilagem costal similar às demais, outrora este par de cartilagens está fundida na linha mediana em forma de "V" que não contata qualquer outra cartilagem costal ou mesmo a esternal. Está fixada na parede do corpo através da musculatura ventral do animal.

Mais quatro costelas dorsais estão presentes na porção caudal do segmento. São estruturas que não contatam a cartilagem esternal e possuem pouca ou nenhuma cartilagem costal. Gradualmente possuem tamanho reduzido e estrutura mais robusta. As duas primeiras costelas são similares as demais costelas dorsais. Possuem corpo alongado, cilíndrico e liso. Sua cabeça é maior que das estruturas anteriormente descritas e a face articular é oval. Estas 
exibem um pequeno tubérculo costal na região do colo. A porção de cartilagem na extremidade livre é pequena. As duas últimas costelas dorsais apresentam aproximadamente um quarto do tamanho das demais, aparentando maior robustez. O corpo é liso, embora seja mais laminar, as extremidades aparentam mais destacadas. A cabeça é quadrangular com face articular similar e um pequeno tubérculo na porção imediatamente ventral a margem desta face. A extremidade livre representa uma lâmina delgada que contata uma pequena porção cartilagínea também laminar.

Costelas lombares - O segmento de vertebras lombares apresenta, assim como os demais anteriormente relatados, um pequeno tubérculo lateral que oferece área articular para costelas. Estas correspondem nas menores costelas presentes em I. iguana. Trata-se de quatro pares de barras cilíndricas, uniformes e retilíneas. Possuem uma cabeça pouco pronunciada e uma fosseta articular circular (Fig. 15E).

\section{Esterno}

A porção esternal apresenta uma interclavícula completamente ossificada. Está localizado na face ventral mediana. A extremidade cranial desta exibe dois pares conspícuos de processos, enquanto a extremidade caudal exibe forma de ponta de lança, estando inserida na cartilagem esternal. O corpo da interclavícula é longo, ligeiramente largo e laminar. Possui a forma de um losango alongado cuja porção mais larga limita a área de contato com a cartilagem esternal. A porção cranial possui um tubérculo mediano formado pela fusão do par de processos presentes nesta região. Da própria estrutura da interclavícula projeta-se um pequeno e pontiagudo processo ventrocaudalmente orientado, o processo ventral. Este possui não mais que um quarto do comprimento da metade cranial da interclavícula (Fig. 19).

O segundo processo possui quase a metade do comprimento total da interclavícula. Situa-se laterodorsalmente, limitando ventralmente um abertura cranial da cavidade celomática. Constitui-se de uma barra robusta e sub-cilíndrica, curvada lateralmente com uma proeminência áspera e larga na extremidade distal. Na porção média exibe uma projeção ventral que forma uma lâmina delgada. As duas peças se unem na porção mediana formando uma sínfise bem destacada.

Grande parte da estrutura do esterno permanece cartilagínea, correspondendo na cartilagem esternal. Abriga medialmente a extremidade caudal da interclavícula e oferece sustentação para as cartilagens costais, ventrolateralmente. Sua estrutura corresponde em uma lâmina extensa, plana e delgada com formato de losango, entalhada na porção cranial pela interclavícula, que se encaixa na porção mediana desta estrutura. 


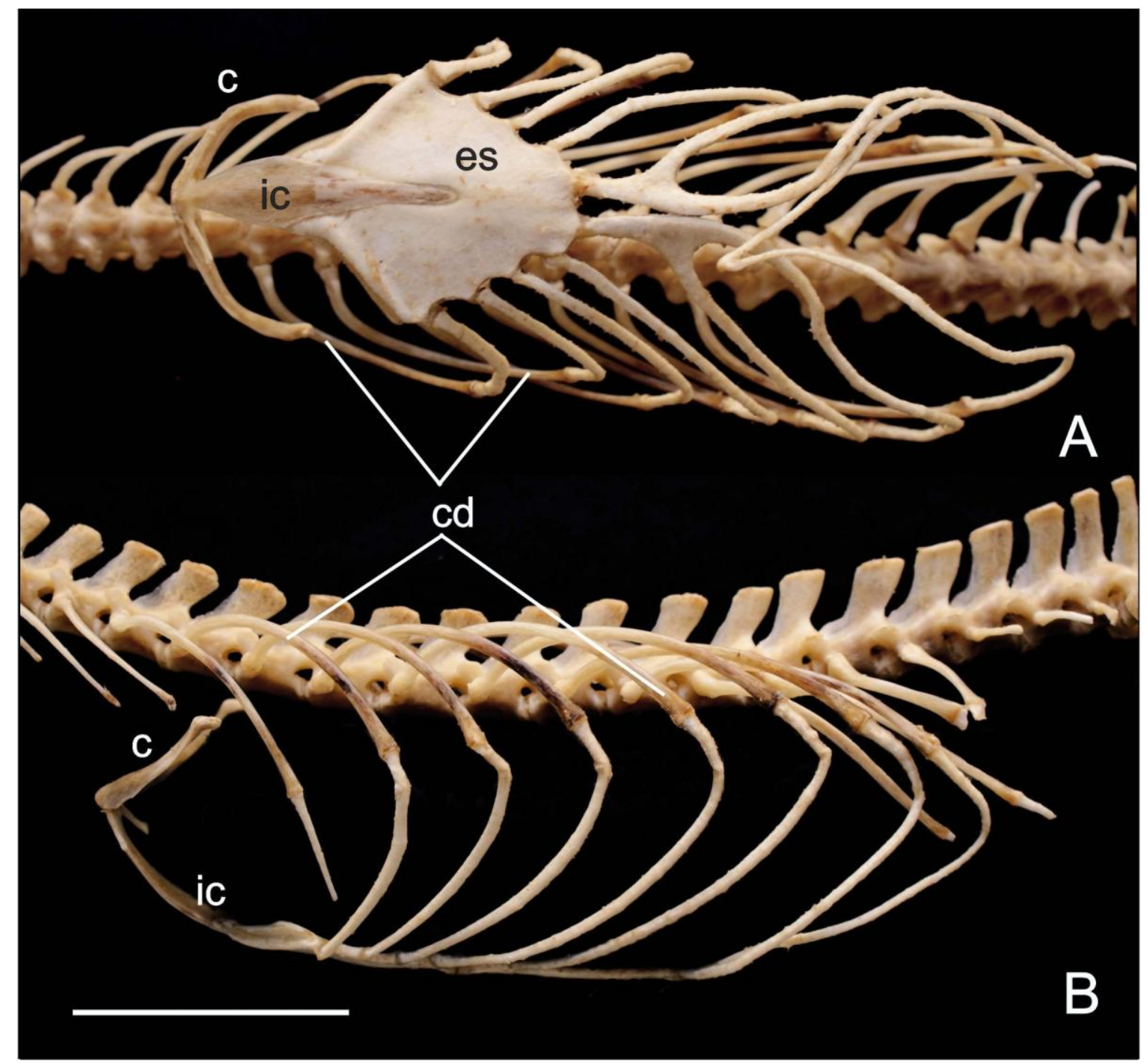

Figura 19: Costelas, vértebras dorsais, esterno e interclavícula de I. iguana iguana adulta. c, clavícula; cd, costelas dorsais; es, esterno; ic, interclavícula. Barra $6 \mathrm{~cm}$.

Laterocaudalmente sua borda é escavada por cinco pares de incisuras que oferecem superfície articular para a cartilagem costal. A extremidade caudal é romba e pequena, comprimida entre as cartilagens do quinto par de costelas. A margem craniolateral é lisa, assim como as faces dorsal e ventral, sendo estas levemente côncavo-convexa, respectivamente. Toda esta porção do esterno embora seja cartilagínea apresenta calcificação da membrana condroide. 


\section{Esqueleto Apendicular}

\section{Membro Torácico}

Escápula - é um osso irregular, alongado e com duas extremidades amplas e algumas projeções. A porção principal, que forma o corpo, corresponde uma barra cuja largura é consideravelmente maior que a altura. É largo, plano e curvado, sendo convexo lateralmente. Sua extremidade ventral menos pronunciada que a dorsal. Apresenta uma dilatação convexa que se articula com o coracóide. A extremidade dorsal é ampla e também convexa, apresentando uma camada de cartilagem que reveste toda sua extensão. Cranialmente exibe uma projeção cônica que se origina na base da face articular com o úmero. A referida face articular situa-se na porção do corpo deslocada dorsalmente e voltada rostralmente. Apresenta uma face oval e alongada levemente estrangulada na porção média formando de cada lado uma pequena incisura. Dorsal e ventralmente exibe um tubérculo discreto na junção com o corpo do osso (Fig. 20A, B e B').

Caudalmente a porção dorsal da face articular existe um forame bem marcado, direcionado ventralmente. A partir do corpo existem três grandes projeções laminares no sentido caudal. Ambas as extremidades também apresentam projeções, outrora menores e mais largas, na mesma direção. Estas se assemelham a pequenas ampulhetas que contatam caudalmente uma porção não ossificada de cartilagem e formam entre estas projeções quatro fenestras amplas.

Coracóide - compreende numa porção cartilagínea cuja membrana externa apresenta-se ossificada, embora a estrutura como um todo permaneça cartilagínea. Assemelha-se a lâmina de um pá, ampla, delgada e larga craniocaudalmente, sendo mais larga em sua porção ventral em relação a dorsal. É convexa lateroventralmente e exibe uma grande e rasa incisura caudal. Suas superfícies são lisas e o contato com a escápula feito por meio de uma estreita margem sub-plana (Fig. 20A e B). 


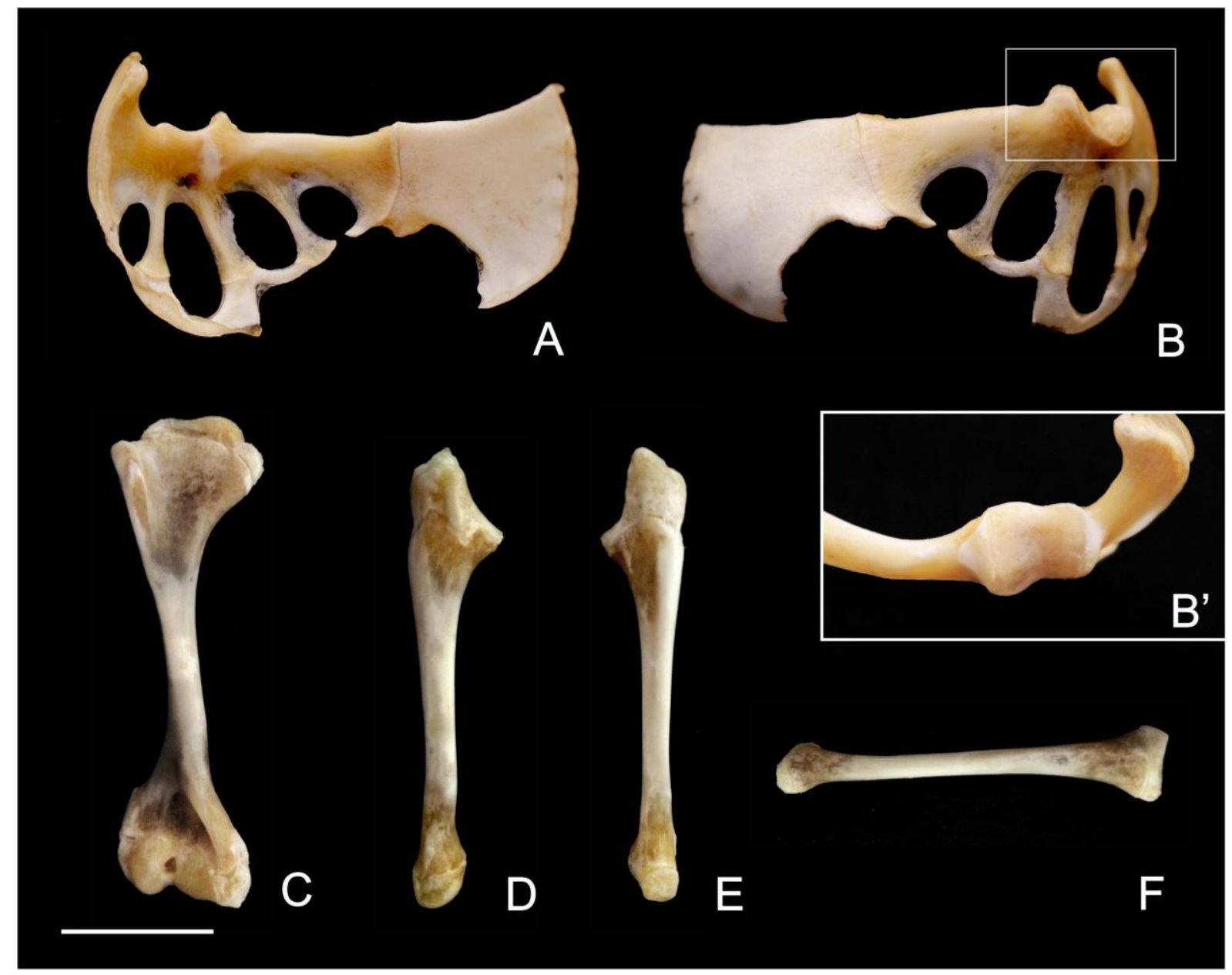

Figura 20: Ossos da cintura peitoral e membros torácicos de I. iguana iguana adulta. Escápula e coracóide, vista ventromedial (A), dorsolateral (B) e detalhe da superfície articular em vista cranial (B'). Úmero, vista lateral (C), ulna, vista medial (D) e lateral (E) e rádio. Barra: $2 \mathrm{~cm}$.

Úmero - O úmero é um osso longo típico. Apresenta uma diáfise sub-cilíndrica que torna-se larga em direção as duas epífises, ambas conspícuas e com tamanho relativamente equivalente. É o maior e mais robusto elemento do esqueleto torácico. Sua diáfise apresenta uma rotação pronunciada que forma um ângulo em relação às epífises (Fig. 20C).

A diáfise é quase cilíndrica e apresenta uma delicada margem caudal com borda quase que totalmente imperceptível. $\mathrm{Na}$ face posterior, medialmente, existe uma área circunspecta com uma pequena ranhura em direção a epífise proximal. A face cranial é lisa e exibe uma discreta convexidade que é mais acentuada na porção distal.

A epífise proximal é alongada e mais larga mediolateralmente, curvando-se caudalmente, formando uma superfície fortemente côncava. $\mathrm{Na}$ extremidade mais proximal da epífise destaca-se uma área coberta por cartilagem articular. Ela apresenta duas porções, uma maior e mais esférica, medialmente, e outra, lateral, menor e relativamente quadrangular. 
Entre elas existe, anteriormente, uma escavação que define sua forma, enquanto que caudalmente elas são praticamente contínuas.

Medialmente a esta face articular existe um proeminente tubérculo estendendo-se obliquamente a partir da face medial da epífise proximal. Este situa-se sobre uma crista larga e possui forma quadrangular, sendo continuo com a crista distalmente e com a face articular lateralmente. Lateralmente existe uma robusta coluna que se projeta da diáfise e se ancora na base da superfície articular, imediatamente lateral a menor porção desta. Possui um contorno quadrangular com sua face lateral lisa e bem marcada por uma crista cranial. Sua face posterior integra-se à parede côncava da epífise e forma a porção mais lateral desta. Imediatamente medial a crista que limita anteriormente esta estrutura, existe uma pequena escavação alongada que se estende até a porção mais proximal da diáfise.

A epífise distal do úmero é tão larga no sentido transversal quanto no craniocaudal, formando uma volumosa e irregular massa óssea cúbica, dividida pelo sulco intercondilar em côndilo lateral e medial, cada um com uma grande superfície articular, sendo o côndilo lateral mais proeminente. Ambos os côndilos são arredondados e possuem as superfícies distal e caudal cobertas por cartilagem articular, enquanto a superfície cranial apresenta poucas rugosidades. O côndilo lateral apresenta uma superfície quase esférica que oferece congruente encaixe a porção proximal do rádio. O côndilo medial é menor e quase plano, mas oferece também um perfeito encaixe a ulna. Entre os côndilos, caudalmente, existe um sulco arredondado e profundo. O côndilo medial se estende cranialmente oferecendo uma superfície articular semelhante a uma pequena tróclea para a ulna durante a extensão. Proximais aos côndilos existem duas pequenas massas ósseas que correspondem aos epicôndilos, sendo o lateral mais pronunciado, demarcando uma estreita linha supraepicondilar. Na face medial, quase caudalmente, está presente uma robusta crista supracondilar, que delimita a parede medial de uma pequena fossa coronóide.

A face caudal da epífise distal é côncava. Existe uma delimitação em suas margens medial e lateral por uma tênue linha supraepicondilar e uma robusta crista supraepicondilar, respectivamente. Lateralmente existe uma fossa delimitada pela crista supraepicondilar e medialmente outra fossa, esta mais rasa, para acomodar o rádio durante a flexão. Acima da fossa radial existe um forame nutrício direcionado proximalmente. Entre elas está presente uma inconspícua projeção óssea que finda na área logo acima do sulco intercondilar.

Ulna - é o osso medial do antebraço, sendo tipicamente longo e retilíneo e formando com o rádio um espaço interósseo. É mais longo e mais robusto que o rádio. Apresenta uma 
diáfise delgada e ligeiramente laminar, com uma pequena torção distal que coloca a epífise distal num pequeno ângulo de inclinação lateral. Apresenta duas cristas largas, uma cranial e outra caudal, que definem duas faces aparentemente lisas, uma lateral e outra medial. A face lateral apresenta uma pequena escavação ao longo de toda sua extensão, um sulco raso. Sua margem interóssea é romba, sendo lisa em sua extensão total (Fig. 20D e E).

A epífise proximal é bastante robusta e possui uma forma aparentemente triangular, delimitando quatro faces que podem ser distinguidas. Uma cranial levemente cônvexa, uma projeção similar a um pequeno tubérculo sugerindo uma semelhança com o olecrano, bastante rugoso e robusto. Outra caudal, côncava, que se articula como côndilo medial do úmero, semelhante a incisura troclear. Nesta existe uma projeção que, durante a flexão, se encaixa na fossa posterior medial do úmero, de modo similar a incisura coronóide e processo coronóide em outros vertebrados. A face medial é plana que se articula com a cabeça do rádio, onde existe uma estreita fossa revestida por cartilagem articular. A última face, a lateral, é levemente plana e com algumas rugosidades.

Contornando a base da epífise proximal, numa região similar a um pequeno colo, existem estrias que denotam regiões de inserção da cápsula articular e de origens musculares. A transição da diáfise com a epífise distal também apresenta uma circunferência similar a um colo com muitas ranhuras que indicam áreas de fixação da capsula articular. Na porção mais distal da diáfise, craniolateralmente existe uma protuberância de inserção muscular.

A epífise distal da ulna é pequena e convexa, a semelhança de uma pequena esfera, embora apresente uma escavação craniomedial que interrompe este contorno. Quase toda sua extensão é revestida com cartilagem articular, que oferece encaixe para o osso radial, distalmente, e para o rádio, lateralmente.

Rádio - Um osso delgado e ligeiramente menor que a ulna. Posicionado na porção lateral do antebraço é cilíndrico, apresenta duas epífises bem definidas, embora a distal seja bem reduzida. Sua diáfise é lisa, exceto por uma pequena área na porção média na face lateral desta que apresenta uma tuberosidade delicada. Existe uma curvatura acentuada distalmente que confere a este osso um aspecto convexo lateralmente (Fig. 20F).

A epífise proximal é quadrangular com sua maior extensão no sentido craniocaudal. A face articular com o côndilo lateral do úmero possui a forma de um platô levemente côncavo e recoberto por cartilagem articular, assim como sua face medial, que se articula com a ulna. Na junção entre a epífise proximal e a diáfise, na face medial, existe um pequeno, porém pronunciado tubérculo. 
Na extremidade distal a epífise não apresenta uma forma conhecida. É alongada craniocaudalmente e apresenta uma incisura escavada ao nível do encaixe com a extremidade distal da ulna.

Ossos do carpo - Embora ainda exista uma certa controvérsia sobre a formação de algumas estruturas do carpo, bem como sua classificação, o carpo de I. iguana apresenta nove ossos, destes, quatro distais do carpo, o radial do carpo, o ulnar do carpo, um central lateral e outro central medial do carpo e o psiforme. Existem ainda alguns sesamóides oriundos de ossificação pós-natal de determinados tendões (Fig. 21).

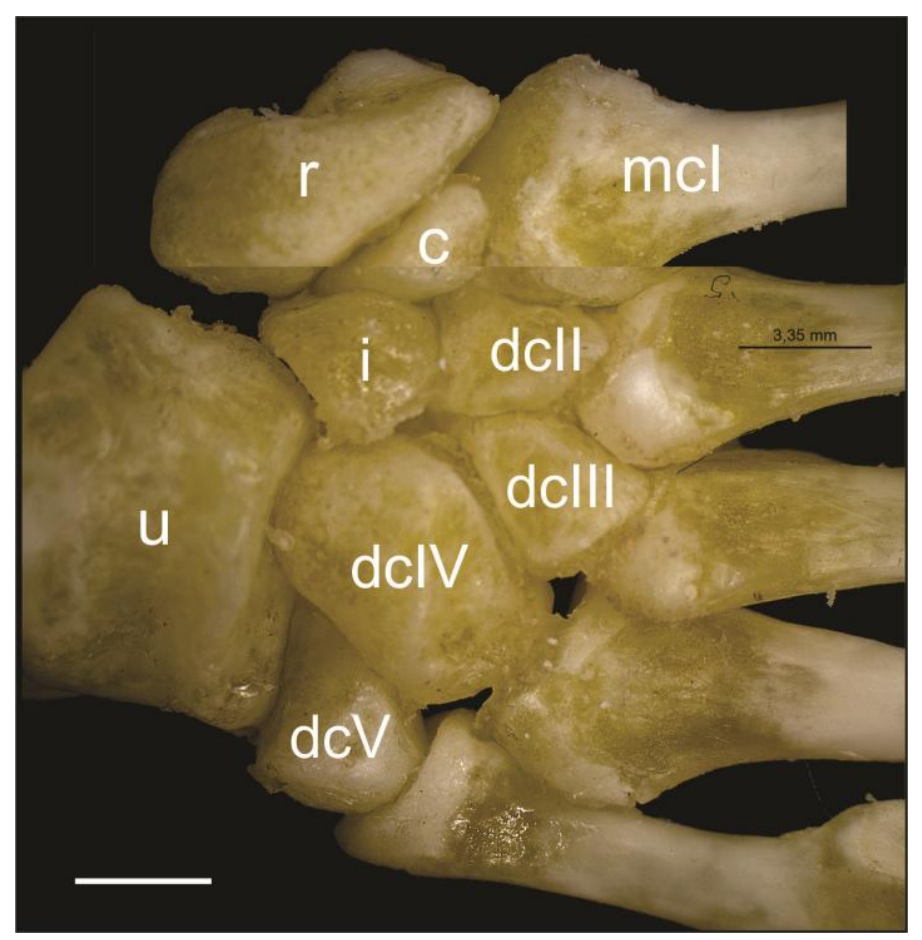

Figura 21: Detalhe do esqueleto da extremidade distal do membro torácico de I. iguana iguana adulta. Vista dorsal. u, ulnar; r, radial; Dc, distais do carpo; c, central; i, intermédio; mcI, metacarpo I. Barra: 3,35mm.

Ulnar - É maior elemento do carpo. É um osso de aparência robusta, quadrangular e com pequenas expansões em suas extremidades, formando uma borda em forma de crista que contorna a superfície articular, deixando o osso com uma cintura. Trata-se de um osso curto que se articula com outros vários ossos do carpo (pisiforme, distal do carpo IV e distal do carpo V, radial e intermédio/cental) além da ulna. A face articular com a ulna é ampla, margeada por bordas ósseas bem definidas que marcam uma superfície côncava. Sua superfície dorsal apresenta uma pequena depressão que circunda toda extensão. A face palmar 
possui uma pequena tuberosidade. Distalmente a face articular é discretamente segmentada em duas pequenas áreas articulares para os ditais do carpo (Figs. 21 e 22).

Radial - É o segundo maior elemento do carpo, representando um osso curto típico, com forma semelhante a um paralelepípedo. Seu corpo largo e robusto, apresenta duas principais faces articulares. Aquela que se articula com o rádio apresenta uma escavação proeminente para melhor congruência com a referida estrutura. A face distal se articula com o distal do carpo I e contata levemente o intermédio/central do carpo medialmente, face pela qual articula amplamente com o ulnar. Em sua face palmar apresenta um tubérculo proeminente. É constrito entre suas extremidades, sendo que suas bordas lateral e medial são côncavas. Sua borda dorsal é levemente linear, enquanto que a ventral é côncava, com a presença de pequenas estrias em ambas (Figs. 21 e 22).

Ele possui três superfícies articulares. A superfície articular proximal, que se articula com o rádio, é ampla, de contorno sub-quadrangular e côncava, a superfície distal articula-se com os metacarpos I e II, sendo levemente ovalada e também côncava. Por fim, sua face medial se articula com o osso ulnar do carpo por meio de uma crista em forma de lingueta, projetada ventralmente.

Distais do carpo - São quatro ossos em série, alinhados aproximadamente na porção proximal de cada metacarpo junto a epífise proximal de cada um deles, distais aos demais elementos do carpo. São ossos curtos e apresentam uma forma predominantemente ovalada ou quadrangular. Suas superfícies dorsal e ventral são convexas, existindo ventralmente, na porção proximal, uma pequena fossa. O distal do carpo IV é o maior e sua forma se assemelha a um cubo, com várias bordas e faces, articulando com o distal do carpo V e III, além do metacarpo IV e do osso ulnar. Sua superfície é irregular e oferece suporte para inserção de tendões e ligamentos (Figs. 21 e 22).

O distal do carpo V é o segundo maior elemento distal. Está imediatamente associado ao metacarpo $\mathrm{V}$ e se articula também com o ulnar, além do distal IV, já mencionado. Apresenta forma ovalada com superfícies irregulares.

Os distais III e II são menores e laminares. Estão justapostos e contatando os respectivos metacarpos, além dos centrais e radial. O distal do carpo I não está presente no animal adulto. 


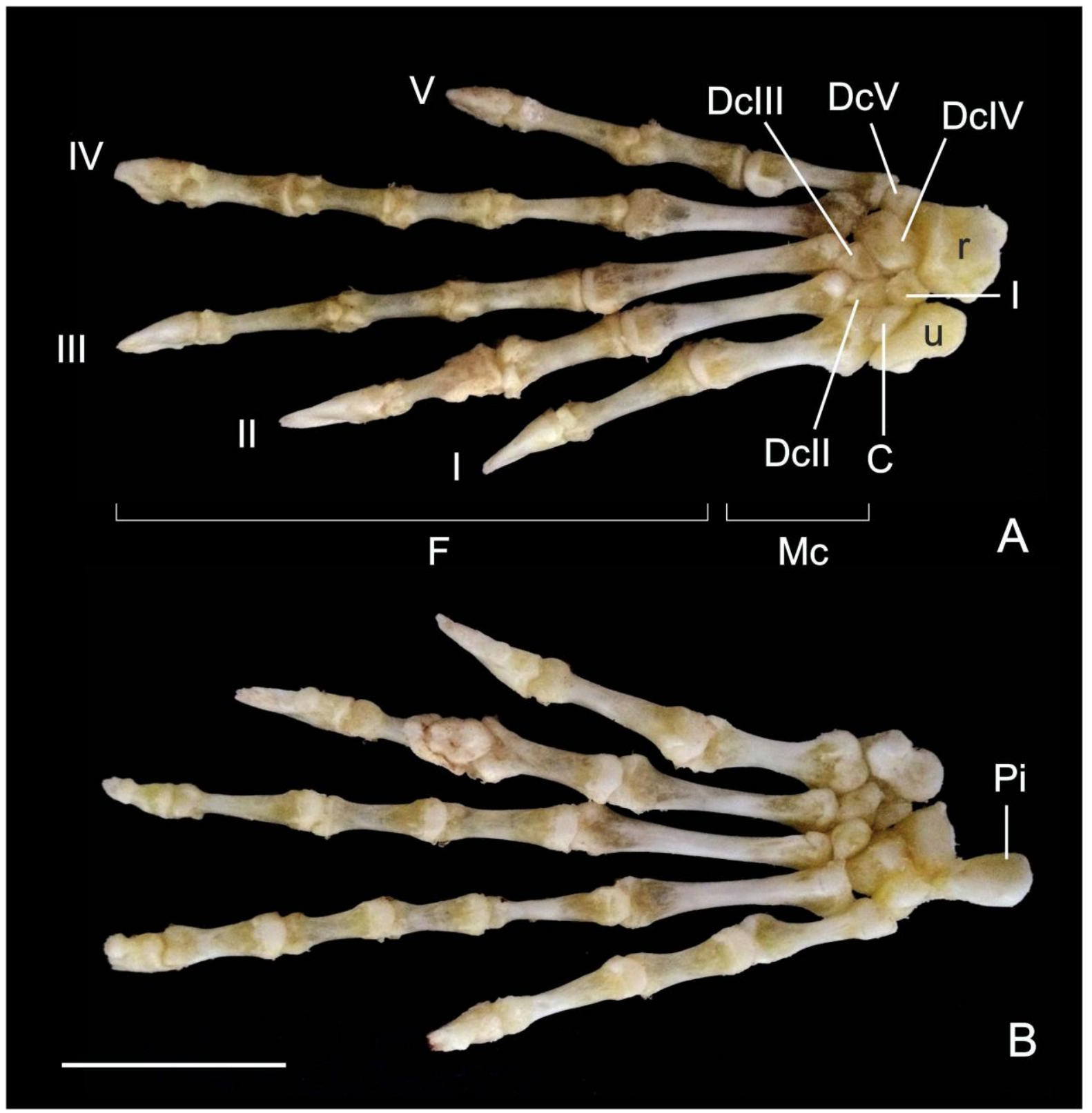

Figura 22: Esqueleto da extremidade distal do membro torácico de I. iguana iguana adulta. Vista dorsal (A) e palmar (B). Digítos I, II, III, IV e V. F, falanges; Mc, metacarpos; u, ulnar do carpo; r, radial do carpo; DcII, distal do carpo II; DcIII, distal do carpo III; DcIV, distal do carpo IV; DcV, distal do carpo V; C, central; I, intermédio; Pi, pisiforme. Barra: $2 \mathrm{~cm}$.

Central do carpo - Corresponde um elemento posicionado na parte interna do carpo. É pequeno e cubóide, estando situado entre o ulnar e metacarpo I (Figs. 21 e 22).

Intermédio - Embora sua presença no carpo de lagartos seja ainda incerta, sua localização e formação (ver adiante) sugere este cenário em I. iguana iguana. Corresponde 
um elemento posicionado na parte central do carpo, cunhado entre os ossos radial e ulnar. É pequeno e subtriangular, contatando distalmente o distal do carpo II (Figs. 21 e 22).

Pisiforme - O osso pisiforme está posicionado na porção mais medial do carpo, contatando apenas com o ulnar, além da ulna. Apresenta forma que lembra um semicírculo. A porção lateral apresenta cartilagem articular enquanto a face medial é convexa e rugosa, oferecendo suporte para inserção de estruturas moles (Fig. 22).

Metacarpos - Os metacarpos de I a V são ossos longos típicos, sendo os ossos II, III e IV relativamente maiores que os demais. Estes ossos estão posicionados proximalmente entre si de maneira imbricada, com todos sobrepondo-se sequencialmente de modo que o elemento posicionado medialmente sobrepõe-se àquele lateral, apenas em contato articular aparente. Existe contato articular com cada distal do carpo, proximalmente (Fig. 22).

A diáfise dos metacarpos é longa, lisa e alargada lateromedialmente, principalmente na região proximal. A superfície articular proximal é elipsóide e mais larga, formando aletas articulares que se imbricam entre si.

Os metacarpos possuem pequenos côndilos, um lateral e outro medial o que aumenta a congruência com as falanges. Estes são voltados para a face palmar, enquanto a superfície dorsal apresenta uma pequena área articular envolvida por cartilagem, facilitando o deslizamento da falange neste sentido. As bordas axial e abaxial na extremidade distal dos metacarpos apresentam uma área rugosa, sendo esta região o ponto de inserção ligamentar e para a capsula articular.

A superfície articular proximal dos metacarpos IV e V mantém um contorno ligeiramente retangular com um pequeno sulco côncavo na porção proximal, formando um discreto platô. Os metacarpos III e II apresentam suas extremidades articulares proximais alongadas, sendo esta epífise relativamente achatada. O metacarpo I possui uma extensa epífise proximal e, consequentemente, uma superfície articular mais pronunciada. Esta possui a forma de um pequeno côndilo de bordas bem marcadas e uma pequena projeção na extremidade medial, servindo com mérito o encaixe entre os distais I e II.

Ao longo do eixo entre as superfícies articulares a diáfise sobre uma pequena torção o que evidencia um ângulo entre a epífise distal e a proximal. A face dorsal dos metacarpos é predominantemente lisa, exceto na transição à superfície articular distal, onde há uma rasa depressão lisa. 
Falanges - As falanges são também tipicamente longas, sendo sua formula falangeal 2:3:4:5:3. Cada uma das falanges, exceto as ungueais, possui uma cabeça, uma diáfise e uma base proximal. A diáfise afila-se em sua porção média, o que evidencia a largura das epífises. Em vias gerais, possuem sua face dorsal ligeiramente convexa enquanto que a palmar é plana ou côncava. As bases das falanges proximais são largas e possuem facetas ovais côncavas adaptadas para as cabeças metacarpais, existindo uma pequena projeção dorsal que se encaixa no sulco entre as facetas da epífise distal dos metacarpos correspondentes. Sua epífise distal representa a cabeça, que é levemente sulcada como polias que salientam-se mais nas faces palmares. As bases das falanges médias, mesmo as médio proximais e médio distais, apresentam duas facetas côncavas separadas por uma discreta crista lisa. As cabeças destas falanges também se assemelham a polias, nas quais estão adaptadas as bases das falanges distais (Fig. 22).

As falanges distais são ditas ungueais. Estas possuem a face dorsal convexa e a palmar côncava, sendo alongadas e piramidais, o que lhes confere o aspecto de garra. Na face palmar existe um pequeno tubérculo onde se insere o tendão do músculo flexor profundo dos dedos.

$\mathrm{Na}$ articulação entre as duas últimas falanges existe em cada dedo um pequeno osso sesamóide que se forma no tendão do músculo extensor, na porção mais dorsal dos dedos.

\section{Membro Pelvino}

Ilíaco - Corresponde em um osso robusto, posicionado laterodorsalmente na pelve. Apresenta um ramo principal direcionado dorsocaudalmente e uma projeção larga cranioventralmente. O ramo dorsal do ilíaco é alongado e representa aproximadamente metade do comprimento total da pelve. É composto por uma longa e maciça barra óssea levemente quadrangular onde estão presentes algumas ranhuras, cristas e impressões. Exibe um pequeno processo cranial triangular onde se inserem alguns tendões.

A porção cranial do ramo dorsal é larga e se direciona ventralmente contribuindo para a formação de aproximadamente dois terços craniais da fossa do acetábulo, em vista lateral. Esta extremidade exibe uma superfície em forma de V que se articula com o púbis e o ísquio, cranial e caudal, respectivamente. Na borda mais dorsal da fossa do acetábulo o ilíaco possui um pequeno tubérculo que exibe o dobro da altura da margem acetabular. Caudalmente, próximo a sutura com o ísquio exibe ainda uma pequena incisura ilíaca. Sua face medial é quase homogênea, exceto pela existência de uma superfície articular para o 
processo transverso das duas vertebras sacrais (costela sacral). Esta face articular exibe uma superfície semilunar que é delineada por uma pequena projeção alongada caudalmente. Esta situa-se na porção cranial do processo dorsal (Fig. 23A, B, B’ e C).

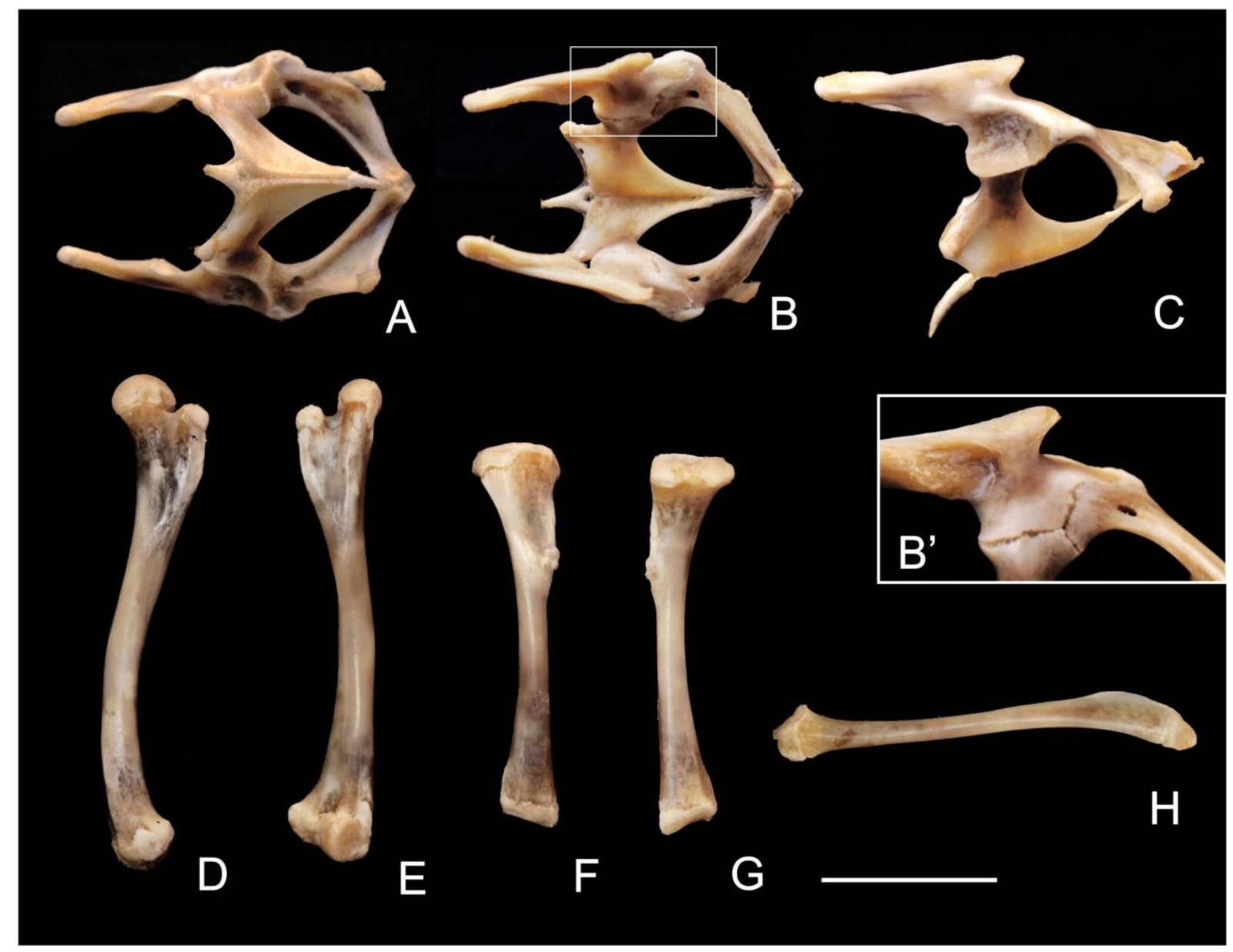

Figura 23: Ossos da cintura pélvica e membros pelvinos de I. iguana iguana adulta. Pelve óssea em vista ventral (A), dorsal (B), lateral (C) e detalhe da vista medial ao nível da articulação dos ossos ilíaco, púbis e ísquio na face interna da fossa do acetábulo (B'). Fêmur em vista lateral (D) e medial (E). Tíbia, vista cranial (F) e caudal (G). Fíbula em vista cranial (H). Barra: $2 \mathrm{~cm}$.

Ísquio - trata-se de um osso irregular posicionado ventrocaudalmente na pelve. Contribui para a formação da porção caudal da fossa do acetábulo e contata seu contralateral na linha mediana, ventralmente. Apresenta uma extremidade larga e delgada, resultado da projeção plana ventralmente, e outra robusta, dorsal, que contata o ilíaco e o púbis. Sua porção média é similar a um pequeno colo ligeiramente cilíndrico. A lâmina ventral do ísquio é triangular e apresenta uma borda ventral convexa. A referida lâmina exibe ainda uma discreta concavidade lateral, sendo inclinada caudalmente. Dorsalmente ele possui um robusto 
processo que contata o íliaco e o púbis e ainda apresenta um proeminente lábio lateral que limita a borda do acetábulo (Fig. 23A, B, B' e C).

A extremidade caudal da lâmina apresenta uma espinha larga e a extremidade cranial exibe uma projeção alongada e piriforme que contata o púbis por meio de uma projeção de tecido conjuntivo. Esta ultima projeção contribui para o fechamento e formação da margem ventrocaudal da fenestra acetabular, que é limitada cranialmente pelo púbis.

Púbis - é um osso notadamente irregular e alongado. Está localizado craniomedialmente na pelve e estende-se obliquamente do ilíaco, na fossa acetabular, caudalmente, até a porção mediana, ventralmente, onde contata seu contralateral. Possui uma borda medial côncava e lisa e outra borda lateral convexa e com alguns acidentes ósseos. A extremidade ventral contata seu contralateral e forma uma sínfise na linha mediana. $\mathrm{O}$ arranjo da coluna principal exibe uma crista continua ventralmente que confere a esta estrutura uma forma trirradiada. Assim, a extremidade ventral possui uma face articular com forma triangular (Fig. 23A, B, B' e C).

A extremidade dorsal é irregular. Possui duas projeções, uma lateral e outra medial, cada uma contribuindo para a formação da porção cranial da fossa do acetábulo e sua margem. Esta margem apresenta um tubérculo conspícuo na região próximo a bifurcação destas duas projeções.

A porção media do púbis é laminar e apresenta uma grande projeção lateral curvada ventralmente. Partindo deste tubérculo na direção caudal existe um discreto colo cuja superfície é lisa e, na base da projeção medial, apresenta um forame arredondado e bem definido.

Formado pela contribuição dos três ossos da pelve, a fossa do acetábulo é subtriangular e rasa. É formada aproximadamente por dois terços do ilíaco e o outro terço pelo púbis e ísquio. Apresenta bordas bem marcadas e uma discreta incisura caudal formada pelo ilíaco.

Fêmur - é o maior osso do esqueleto de I. iguana. É robusto e aparentemente forte, cujas feições gerais mais conspícuas são o tamanho, sua rotação e curvatura. Possui uma diáfise longa e cilíndrica, uma epífise proximal constituída de uma cabeça articular proeminente e a epífise distal possui dois côndilos. Sua diáfise apresenta uma torção de modo que os côndilos e a cabeça estão posicionados em planos suavemente divergentes, sendo cilíndrica ou levemente ovalada (Fig. 23D e E). 
A epífise proximal é bastante irregular e apresenta diversos acidentes ósseos. Esta porção exibe uma conspícua projeção semelhante a uma esfera alongada, a cabeça do fêmur, separada da estrutura geral da epífise por um discreto colo. Nele estão presentes diversas rugosidades e estrias longitudinais, que possivelmente correspondem a pontos de ancoragem de ligamentos ou para inserção muscular. A cabeça do fêmur é robusta e sua porção mais proximal é revestida por cartilagem, sendo sua face articular convexa e ampla. No colo, em sua porção medial, existe uma tuberosidade larga para inserção muscular. Lateralmente há uma massa óssea saliente, embora mais discreta que a volumosa forma da cabeça. Esta tuberosidade oferece uma ampla área para fixação de tendões e ligamentos na porção lateral do fêmur. Este se projeta até o nível da base da cabeça do fêmur, estando posicionado sobre uma respeitável coluna que se projeta da porção proximal da diáfise. Entre estas duas estruturas existe uma incisura que caudalmente exibe uma pequena fossa. Esta fossa distingue duas cristas, uma que finda na base do trocânter e outra na base caudal da cabeça.

Apesar de sua forma cilíndrica na porção média, a diáfise se expande nas porções proximal e distal em direção as epífises. A face cranial proximal é fortemente rugosa e quase tão larga quanto o terço distal. O corpo do fêmur apresenta uma conspícua curvatura que confere a face cranial um aspecto convexo.

A porção distal da diáfise é bem rugosa lateralmente, evidenciando dois pequenos epicôndilos destacadas da estrutura principal desta. Cranialmente existe uma extensa área semi-plana, com uma discreta escavação larga, que logo abaixo é continua com a depressão formada pela fossa intercondilar.

$\mathrm{Na}$ face caudal estão presentes duas linhas de inserção muscular que se estendem longitudinalmente até a base das cristas onde repousam o trocânter e a cabeça na epífise proximal.

A epífise distal do fêmur é quadrangular formando uma volumosa e irregular massa óssea cúbica, estrangulada em duas porções pelo sulco intercondilar em côndilo lateral e medial. Cada um possui uma superfície articular convexa, que juntas se assemelham a uma ampulheta. A superfície articular do côndilo lateral é menor e menos convexa que a medial. Estas são separadas caudalmente por uma fossa ligeiramente profunda. Acima dos côndilos, em sentido proximal, várias pequenas estrias longitudinais estão presentes.

Dois discretos tubérculos denominados epicôndilo lateral e epicôndilo medial estão presentes nas porções lateral e medial dos côndilos. A face cranial do côndilo medial é escavada, formando uma pequena crista marginal, sendo esta sua face plana. 
Tíbia - corresponde no maior osso da perna. É longo, apresenta duas extremidades bem distintas e destacadas do corpo arqueado. Sua diáfise é cilíndrica e curvada crâniomedialmente. Assume uma pequena expansão na direção proximal até se unir a epífise proximal, bem larga e quadrangular. No terço proximal apresenta duas margens bem marcadas que definem duas faces. A margem cranial é bem evidente e larga, findando na base do grande e quadrangular côndilo que forma a epífise proximal. Na base desta margem existe uma tuberosidade larga e pouco proeminente e lateralmente a esta uma outra maior e mais proeminente, posicionada entre a margem cranial e a margem lateral. A porção mais proximal da margem cranial se alarga e apresenta algumas estrias longitudinais bem marcadas (Fig. 23F e $\mathrm{G})$.

Sendo um pouco mais discreta e delgada, a margem lateral se estende da tuberosidade lateral até a base do côndilo lateral. Estas margens delimitam duas faces, uma lateral plana e outra caudomedial convexa. A porção distal da diáfise é quadrangular, acompanhado a forma da epífise distal. Sua face caudal é plana e lisa enquanto a face cranial é levemente convexa e apresenta poucas estrias longitudinais.

Apresentando um formato bem irregular a epífise proximal é robusta e acompanha a curvatura medial da diáfise, estando deslocada do eixo principal do membro. Na face articular existe um platô discretamente convexo, quase plano, dividido em duas porções, ou côndilos, por um a escavação rasa. O côndilo medial é maior e mais ovalado que o lateral, mais alongado. São cobertos por cartilagem articular e apresentam um infundíbulo cranial que unem estas duas porções. Na face cranial, na base do côndilo medial existe uma pequena tuberosidade. A face articular com a fíbula é discreta e posicionada na base lateral do côndilo lateral, na área imediatamente acima da margem lateral.

A epífise distal é menor e apresenta menos irregularidades que a proximal. Esta possui a forma que lembra um paralelepípedo, com a face articular levemente côncava. Lateralmente possui uma projeção com a base larga que oferece uma superfície articular para a fíbula. Medialmente, na transição com a diáfise, existe uma rugosidade que fornece suporte para inserção muscular e ligamentar.

Fíbula - É um osso extremamente delgado sem grandes acidentes ósseos. Sua diáfise é cilíndrica e demasiadamente fina. Nas porções proximal e distal se alarga pouco para acompanhar a morfologia das epífises. Sua porção proximal se torna laminar e exibe duas margens delgadas e marcantes. As faces medial e lateral são côncava e convexa, respectivamente, exibindo uma aba estreita na margem medial. A epífise proximal é pequena 
e constituída de uma cabeça diminuta com uma pontiaguda e discreta projeção. Medialmente é revestida por cartilagem articular, contatando a porção lateral da base do côndilo lateral da tíbia (Fig. 23H).

Pequenas estrias para inserção capsular estão presentes na porção distal da diáfise, próximo a base da epífise distal. Esta extremidade possui uma superfície côncava para articular com o tarso e uma pequena área plana na face medial para articulação com a tíbia.

Ossos do tarso - A semelhança de outros grupos de répteis, o tarso de I. iguana iguana é reduzido. Estão presentes três ossos, embora ainda existam algumas dúvidas sobre sua classificação, principalmente sem uma analise do desenvolvimento. O fibular+intermédio formam um robusto proximal do tarso, existe um distal do tarso III e outro distal do tarso IV. (Fig. 24).

Fibular+astragalus (Proximal do tarso) - Trata-se da maior e mais robusta formação óssea do tarso. Localizado na porção proximal do tarso está em contato íntimo com a fíbula e a tíbia e, distalmente, com o distal do tarso IV, distal do tarso III e o metatarso V. É um osso extremamente irregular, oferecendo pontos para ancoragem de tecidos moles em todas as suas faces. Embora não apresente uma forma definida, é possível observar duas faces largas e duas bordas sinuosas. A face dorsal é completamente escavada por depressões e tuberosidades que suportam muitos ligamentos e alguns tendões. A face plantar é ligeiramente lisa e côncava, apresentando na porção mais lateral uma pequena projeção em forma de hámulo (Fig. 24).

Sua borda proximal é larga e segmentada em duas extensas áreas articulares por uma pequena crista. Ambas as áreas são dotadas de cartilagem articular. A porção medial é irregular, côncavo-convexa e oblíqua, acomodando a epífise distal da tíbia. A porção lateral é estreita e côncava, alojando a extremidade distal da fíbula. 


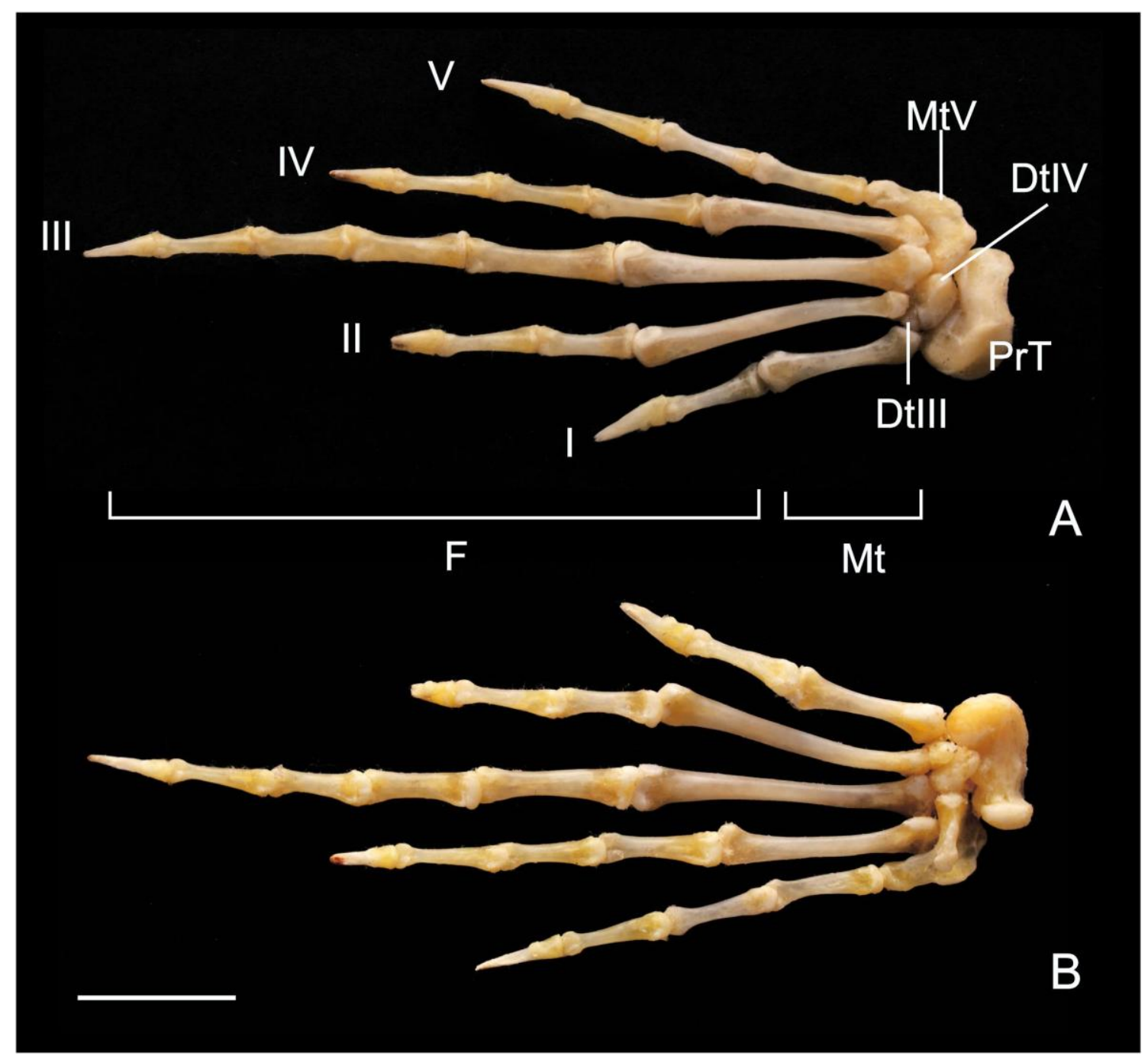

Figura 24: Esqueleto da extremidade distal do membro pelvino de I. iguana iguana adulta. Vista dorsal (A) e plantar (B) do pé. Artelhos I, II, III, IV e V. F, falanges; Mt, metatarsos; MtV, metatarso V; DtIII, distal do tarso III; DtIV, distal do tarso IV; PrT, proximal do tarso. Barra: $2 \mathrm{~cm}$.

A margem distal é bastante sinuosa, oferecendo congruentes áreas articulares com o metatarso $\mathrm{V}$ e os distais do tarso IV e III, além de um pequeno contato com o metatarso I. A porção articular com os distais possui dois sulcos marcados por uma crista e bordas salientes delimitadas por duas conspícuas massas ósseas.

Distal do tarso III - O distal do tarso III é o menor osso do tarso. É um elemento similar a um pequeno paralelepípedo alojado numa pequena fossa rasa na porção latero-distal do distal do tarso VI. Ele possui seis pequenas faces e suas principais superfícies articulares são planas ou levemente côncavo-convexas (Fig. 24). 
Distal do tarso IV - O distal do tarso IV é um osso curto e irregular. Não possui margens ou faces definidas. Sua porção distal é saliente com contorno subtriangular, enquanto sua porção proximal apresenta uma projeção que se encaixa num processo articular convexo do proximal do tarso (Fig. 24).

A superfície articular medial orienta-se na direção medioplantar, sendo plana, enquanto a superfície articular lateral é levemente côncava contatando o metatarso V. Sua porção plantar é convexa e estreita.

Metatarsos - Os metatarsos são ossos longos típicos, sendo os ossos II e III relativamente maiores que os demais. Estes articulam-se proximalmente de maneira imbricada, com uma leve sobreposição sequencial (Fig. 24).

A diáfise dos metatarsos é longa, lisa e alargada lateromedialmente, principalmente na região proximal, onde esta e a superfície articular proximal são condilares e mais largas, formando platôs articulares que se encaixam perfeitamente nos ossos da porção distal do tarso. A face dorsal da epífise proximal é levemente sulcada, oferecendo passagem ao tendão dos extensores dos dedos.

A superfície articular distal de todos os metatarsos mantém um contorno ligeiramente retangular e convexo, semelhante a uma pequena saliência discretamente sulcada na porção plantar, que a divide em dois pequenos côndilos levemente assimétricos, sendo sua distinção muito tênue.

A face dorsal dos metatarsais é predominantemente lisa, exceto junto às áreas próximo a transição com as epífises onde existem algumas ranhuras para inserção capsular.

O metatarso V apresenta morfologia totalmente diferenciada dos demais. Sua porção distal é alongada e exibe uma extremidade articular convexa com um pequeno côndilo que contata a porção proximal côncava da falange I deste artelho. Inserido na região do tarso, a extremidade proximal deste é larga e robusta, contatando o Astrágalus+Calcâneo, os metatarsos IV e III e o distal do tarso IV, oferecendo uma ampla superfície côncava para o contato com este.

Sua face plantar é bastante irregular, exibindo um proeminente tubérculo plantar lateralmente direcionado. Sua borda distal apresenta uma margem bem marcada por uma crista rombóide e sinuosa, dorsalmente localizada a uma escavação rasa e côncava. A forma aproximada deste é similar a um L com a incisura voltada medialmente, alojando a epífise proximal do metatarso IV. 
Falanges - As falanges são muito similares em ambos os membros, pelvino e torácico. A fórmula falangeal é 2:3:5:4:4 (Fig. 24). Não existem diferenças anatômicas evidentes, portanto, para completa descrição destas estruturas consulte os dados relatados para as falanges no membro torácico (Fig. 22). 


\subsection{DETERMINAÇÃO DOS ESTÁGIOS EMBRIONÁRIOS}

Descrevemos 17 estágios de desenvolvimento para I. iguana iguana a partir do primeiro dia de incubação. A coleção completa perfaz 44 estágios de desenvolvimento dos quais os 27 primeiros correspondem no desenvolvimento intra-uterino dos embriões. Tais estágios foram classificados de acordo com dados da anatomia externa dos espécimes. O primeiro estágio descrito foi o estágio 28, visto características similares dos embriões com aquelas de outras descrições relatadas na literatura.

Segue abaixo uma descrição pormenorizada das características presentes nos espécimes classificados dentro de cada estágio, bem como um resumo (Tab. 1) com os principais eventos de desenvolvimento externo em I. iguana iguana.

Estágio 28 - Os embriões apresentam brotos dos membros torácicos e pelvinos, estes primeiros ligeiramente mais pronunciados. 36 pares de somitos que se estendem da porção caudal da cabeça até a cauda. Estão presentes quatro arcos faríngeos dos quais o primeiro representa o processo maxilar e mandibular, que se estende até a área na porção média do olho (Fig. 25A). O coração tubular em desenvolvimento é visível (Fig. 26A). As vesículas cerebrais prosencéfalo e mesencéfalo são visíveis e o rombencéfalo permanece aberto. A flexura mesencefálica é evidente sendo a flexura cranial estabelecida no nível dos arcos faríngeos. A cauda está enovelada. O placóide optico é visível e parece se desenvolver em estágios anteriores. O embrião neste estágio exibe o início da formação da vesícula do cristalino e o placoide nasal (Figs. 25, 27, 28, 30 e 31).

Estágio 29 - O aspecto geral dos embriões permanece similar ao dos espécimes do estágio anterior, porém estão presentes cinco arcos faríngeos e a fossa nasal é facilmente identificada (Fig. 28). 38 pares de somitos. Não são notadas diferenças representativas no desenvolvimento dos membros. O broto torácico apresenta uma sutil curvatura e permanece ligeiramente maior que o broto pelvino. O coroação tubular se dobra (Figs. 26B, 27, 28, 30 e $31)$.

Estágio 30 - Os membros estão mais pronunciados em relação ao estágio anterior e iniciam a formação do disco digital. O broto do membro torácico está direcionado caudalmente. O processo maxilar é um pouco mais conspícuo. Os arcos faríngeos são menos distintos e os sulcos entre os mesmos desapareceram visto que o segundo arco recobre os demais. As vesículas cerebrais permanecem sem grandes alterações (Fig 28). O mesencéfalo é a porção mais proeminente do encéfalo em desenvolvimento. A abertura remanescente do tubo neural não é mais visível. A flexura cervical permanece formando um ângulo agudo ao 
nível do arco faríngeo mais caudal. Os olhos apresentam uma ligeira pigmentação inicial (Figs. 27, 28, 30 e 31).

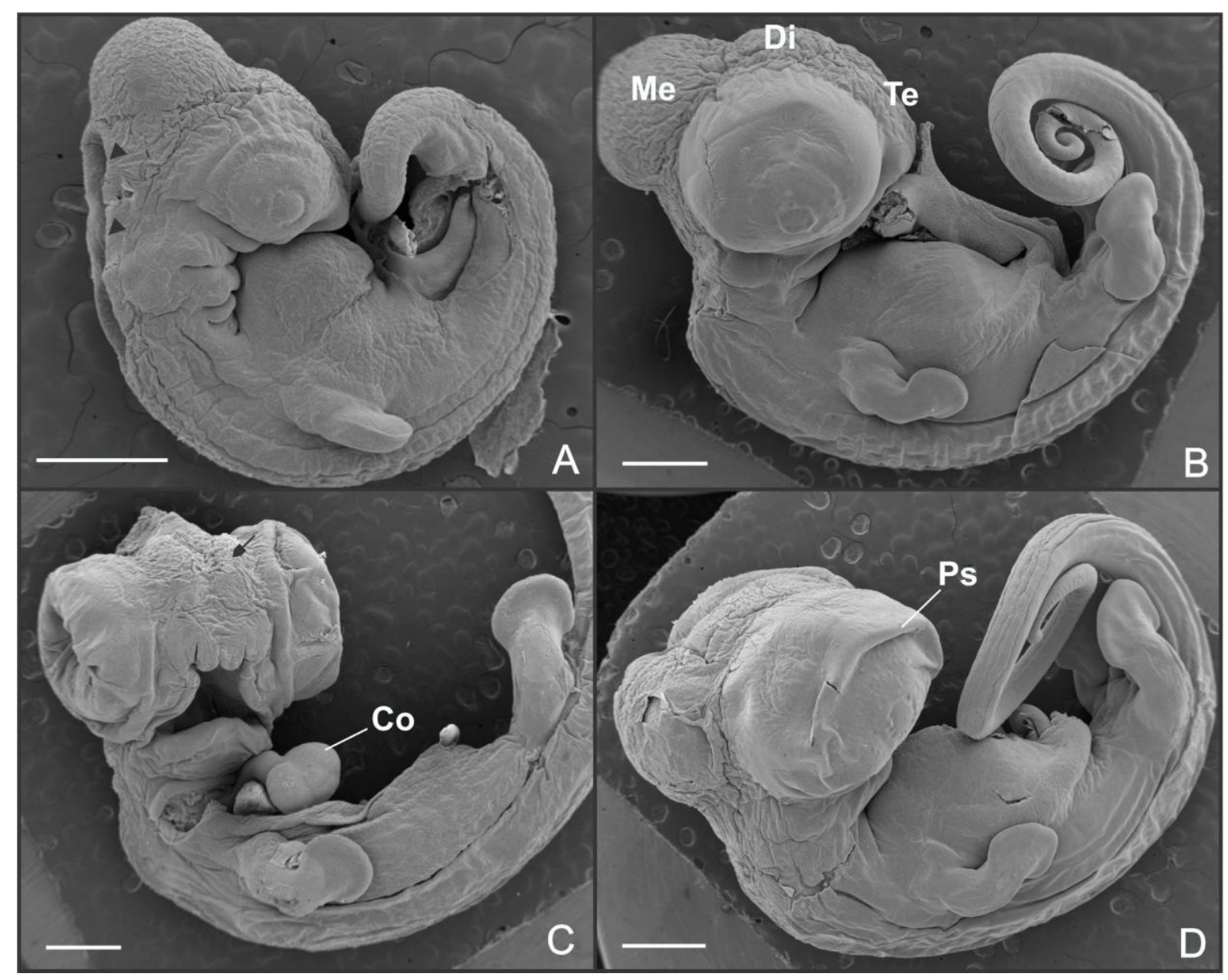

Figura 25: Desenvolvimento de embriões de I. iguana iguana. Microscopia eletrônica de varredura. A; estágio 28 (com abertura do tubo neural, cabeça da seta). B; estágio 31. C; estágio 32. D; estágio 33. Me, mesencéfalo; Di, diencéfalo; Te, telencéfalo; Co, coração; Ps, pálpebra superior. Barra $300 \mu \mathrm{m}$.

Estágio 31 - Estão presentes flexuras nos brotos dos membros torácicos que indicam a formação do cotovelo. Os olhos são bem proeminentes e a pigmentação agora bem evidente. O desenvolvimento do coração avança e é possível observar ventrículo e átrio distintos (Figs. $25,26 \mathrm{C}, 27,28,30$ e 31 ).

Estágio 32 - Aparecem flexuras nos brotos dos membros pelvinos indicando a formação dos joelhos. Em ambos os brotos dos membros é possível distinguir três segmentos. O desenvolvimento dos membros avança sendo possível visualizar o primórdio dos dígitos, principalmente nos membros torácicos. O processo maxilar se estende rostralmente e alcança 
a margem dos olhos. Pigmentação é visível na margem periférica da íris. A fenda nasolabial ainda está presente. O coração é visível através da parede anterior do corpo, sendo possível identificar ventrículo, átrio e bulbo. A protuberância anterior na parede corporal permite ainda evidenciar o fígado em crescimento. Entre os membros pelvinos é visível neste estágio a abertura do poro genital (Figs. 25, 27, 28, 30 e 31).

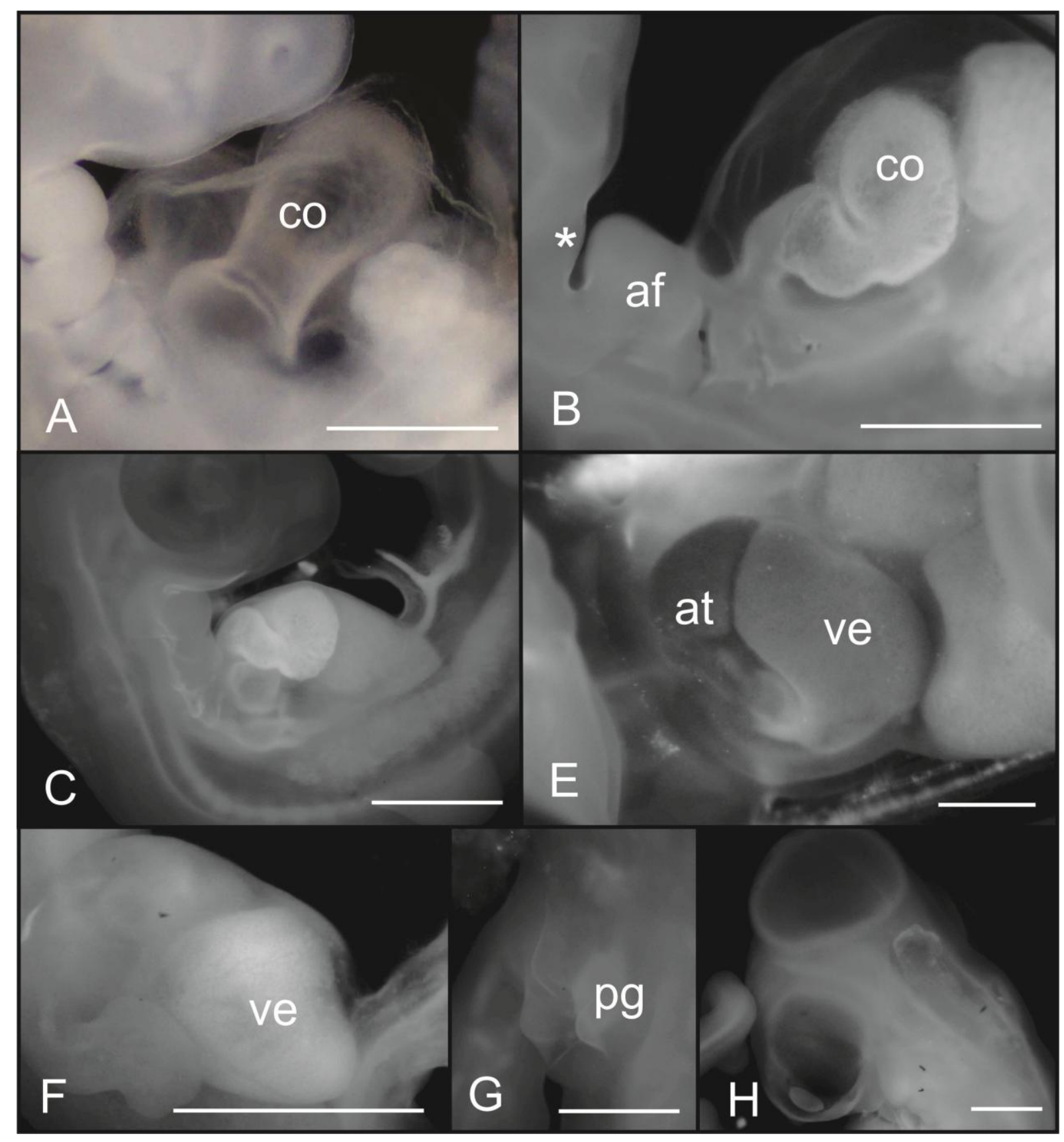

Figura 26: Detalhes do desenvolvimento dos embriões de I. iguana iguana. A, estágio 28. B, estágio 29. C, estágio 31. D, estágio 33. E, estágio 35. F, estágio 34. G, estágio 30. af, arcos faríngeos (* processo maxilar); at, átrio; co, coração; pg, papila genital; ve, ventrículo. Barra: $4 \mathrm{~mm}$. 


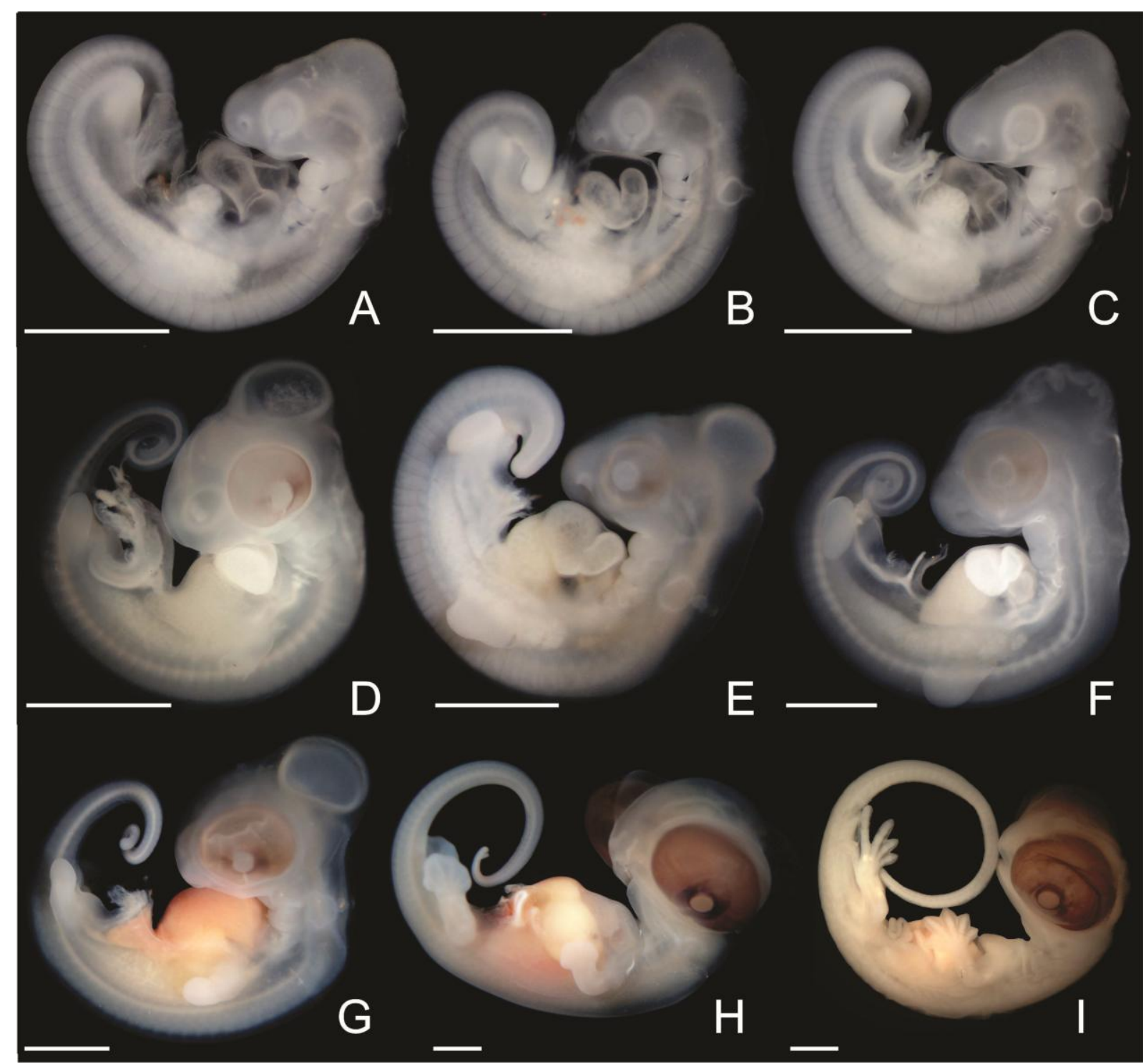

Figura 27: Embriões de I. iguana iguana. A; estágio 28. B; estágio 29. C; estágio 30. D; estágio 31. E; estágio 32. F; estágio 33. G; estágio 34. H; estágio 35. I; estágio 36. Barra $5 \mathrm{~mm}$.

Estágio 33 - Os arcos faríngeos estão aparentemente fundidos e o processo maxilar se avança rostralmente além da margem dos olhos. As placas digitais são bem conspícuas, porém mais pronunciadas nos membros torácicos. Os brotos dos membros neste estágio estão equivalentes. É possível observar a presença do olho pineal na porção mediana da superfície craniana. O crânio presumidamente avança sua formação e o encéfalo agora é menos proeminente (Figs. 25, 26D, 27, 30 e 31). 
Estágio 34 - Os membros se encontram bem desenvolvidos com a presença de dígitos. Membrana digital bem pronunciada nos membros pelvinos e aumento na pigmentação no olho. É possível pela primeira vez visualizar a presença da pálpebra superior. Uma fossa suave marca a região nasal, que ainda é pouco pronunciada. Uma grande fontanela esta presente na porção parietal do crânio. Os globos oculares correspondem metade de todo tamanho do crânio neste estágio. A protuberância do coração é ainda visível, porém não tão pronunciada quanto em estágios anteriores (Figs. 27, 30 e 31).

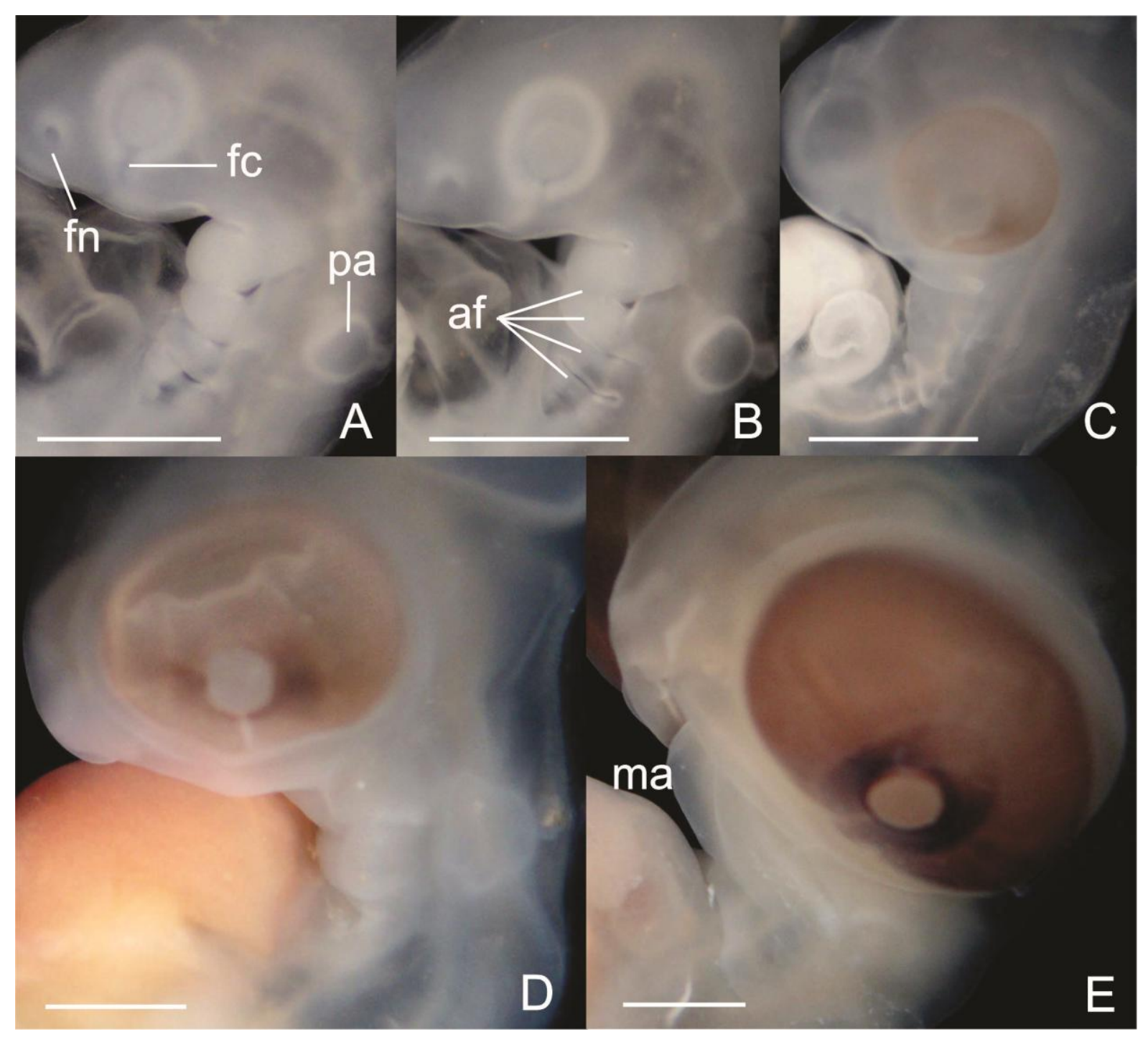

Figura 28: Detalhes do desenvolvimento dos embriões de I. iguana iguana. A e B; estágio 29. C; estágio 30. D; estágio 31. E; estágio 32. af, arcos faríngeos; fc, fissura coroide; fn, fosseta nasal; ma, mandíbula; pa, placóide auditivo. Barra: 2mm. 
Estágio 35 - Presença de membrana interdigital no membro torácico e uma suave pigmentação no membro pelvino. A boca está fechada, porém a mandíbula ainda é ligeiramente menor que a porção maxilar (Fig. 27).

Estágio 36 - Dígitos visivelmente formados em ambos os membros com redução considerável da membrana digital. Presença da pálpebra inferior. Está presente o primórdio das garras nos artelhos. A porção superior do crânio (supostamente a porção ocupada pelo parietal) permanece ainda com desenvolvimento lento. A fontanela cranial é bem visível e ampla, por onde é possível visualizar ainda a proeminência do mesencéfalo e o olho pineal. A íris apresenta coloração escura, estando as pálpebras ainda bem abertas. A abertura da fossa auditiva está bem marcada. Mandíbula e maxila possuem o mesmo tamanho (Figs. 27, 30 e $31)$.

Estágio 37 - Ausência completa de membrana digital. Presença do proeminente órgão genital no poro genital. A fossa auditiva está presente na face lateral do crânio com o primórdio do tímpano. Presença de garras nos dígitos dos membros pelvinos. O tamanho corporal é visivelmente maior a partir dos 24 dias, bem como a coloração que se apresenta de forma mais conspícua e cinza. Coração posicionado na cavidade pericárdica (Fig. 29 e 32).

Estágio 38 - As pálpebras se desenvolveram de modo a fechar metade do olho. A cauda apresenta tamanho considerável em relação aos embriões de outros estágios anteriores. Externamente pela primeira vez é possível observar a presença de elementos ossificados no crânio (Fig. 24B). Primórdios de escamas estão presentes no dorso dos espécimes, na região do pescoço. A barbela na porção inferior da mandíbula está presente. Presença de garras nos dígitos dos membros torácicos. Parte do órgão genital encontra-se incluso no poro genital (Figs. 29, 30, 31 e 32E).

Estágio 39 - A aparência da parede corporal expressa robustez. Coloração e tamanho do corpo, embora evidente, exibem pouco diferença (Fig. 32C). A fossa nasal está bem formada. Na cauda estão presentes primórdios de escamas nos membros torácicos e nos dedos. Presença da membrana timpânica na cavidade da orelha. Primórdio de escamas (Figs. 29, 30 e 31). 


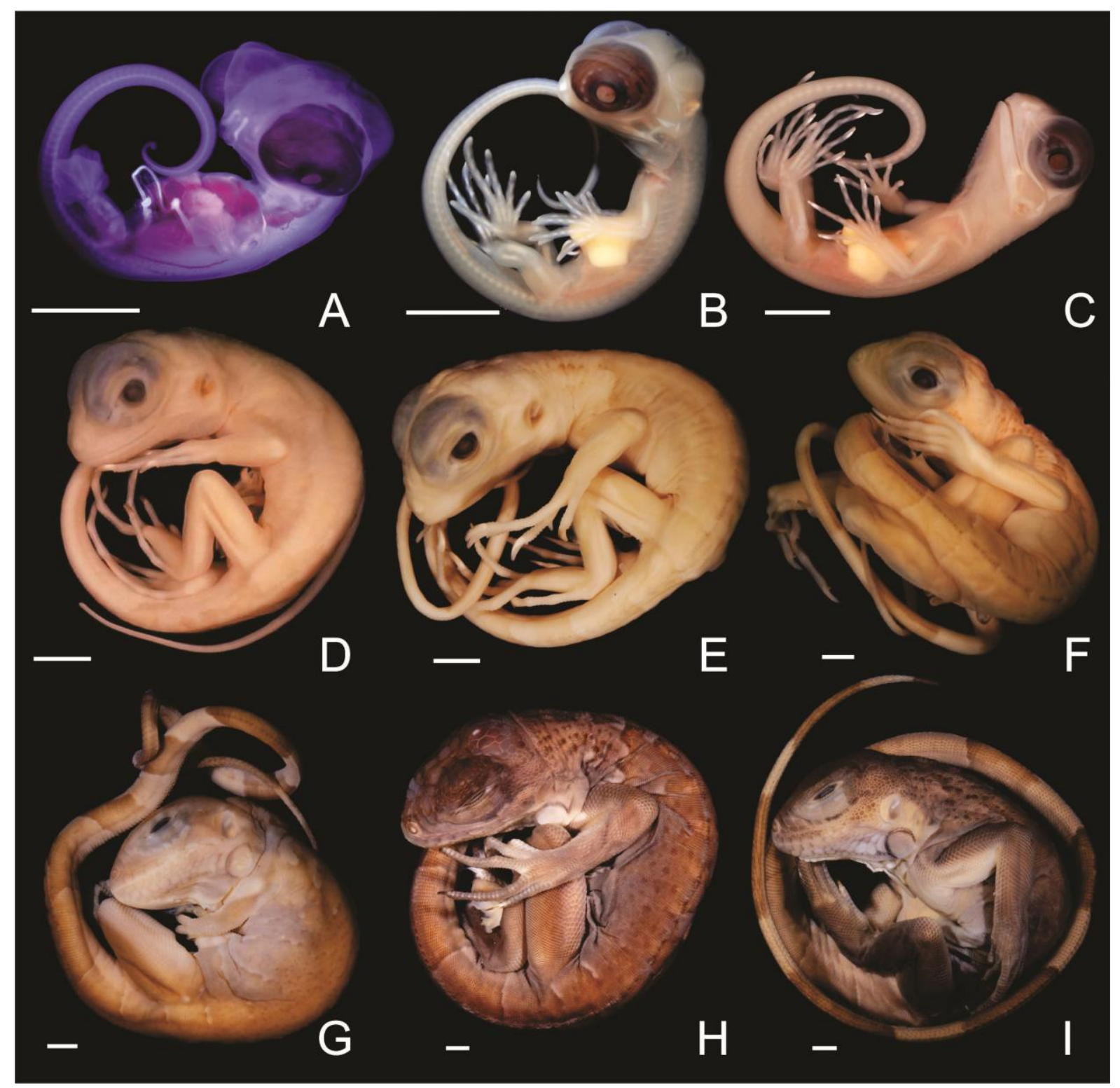

Figura 29: Embriões de I. iguana iguana. A; estágio 37. B; estágio 38. C; estágio 39. D; estágio 40. E; estágio 41. F; estágio 42. G; estágio 43. H; estágio 44. I, recém eclodido. Barra $1 \mathrm{~cm}$.

Estágio 40 - Genitais completamente inclusos no poro genital. Primórdio de escamas nos membros pelvinos e aumento considerável do tamanho corporal (Figs. 29, 30 e 31).

Estágio 41 - Nestes embriões a pigmentação corporal expressa uma coloração cinza bem marcante e primórdios de escamas estão presentes em várias regiões do corpo como cabeça, dorso e pálpebras. O tamanho corporal sofre considerável aumento o que torna tais embriões bastante diferenciados a partir deste estágio (Figs. 29, 30, 31, 32H e 32J). 


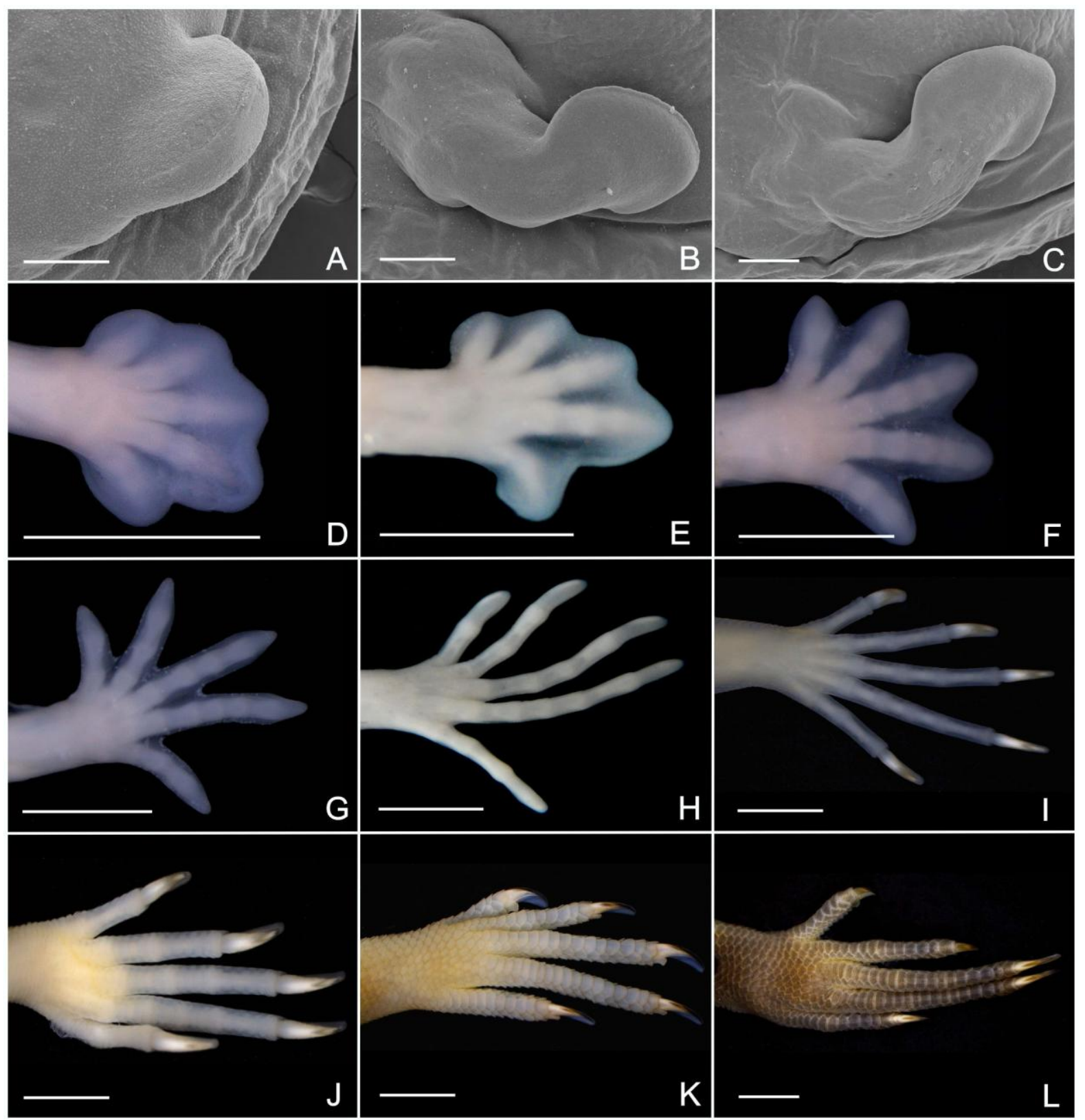

Figura 30: Sequência de desenvolvimento do membro torácico em embriões de I. iguana iguana. Microscopia eletrônica de varredura do broto do membro nos estágios 28 (A), 29 (B) e 30 (C), onde é possível notar a formação e desenvolvimento da placa digital. Barra $300 \mu \mathrm{m}$. Fotografias nos estágios 31 (D), 32 (E), 33 (F), 34 (G), 36 (H), 38 (I), 40 (J), 43 (K) e 44 (L). Barra: $1 \mathrm{~mm}$. 


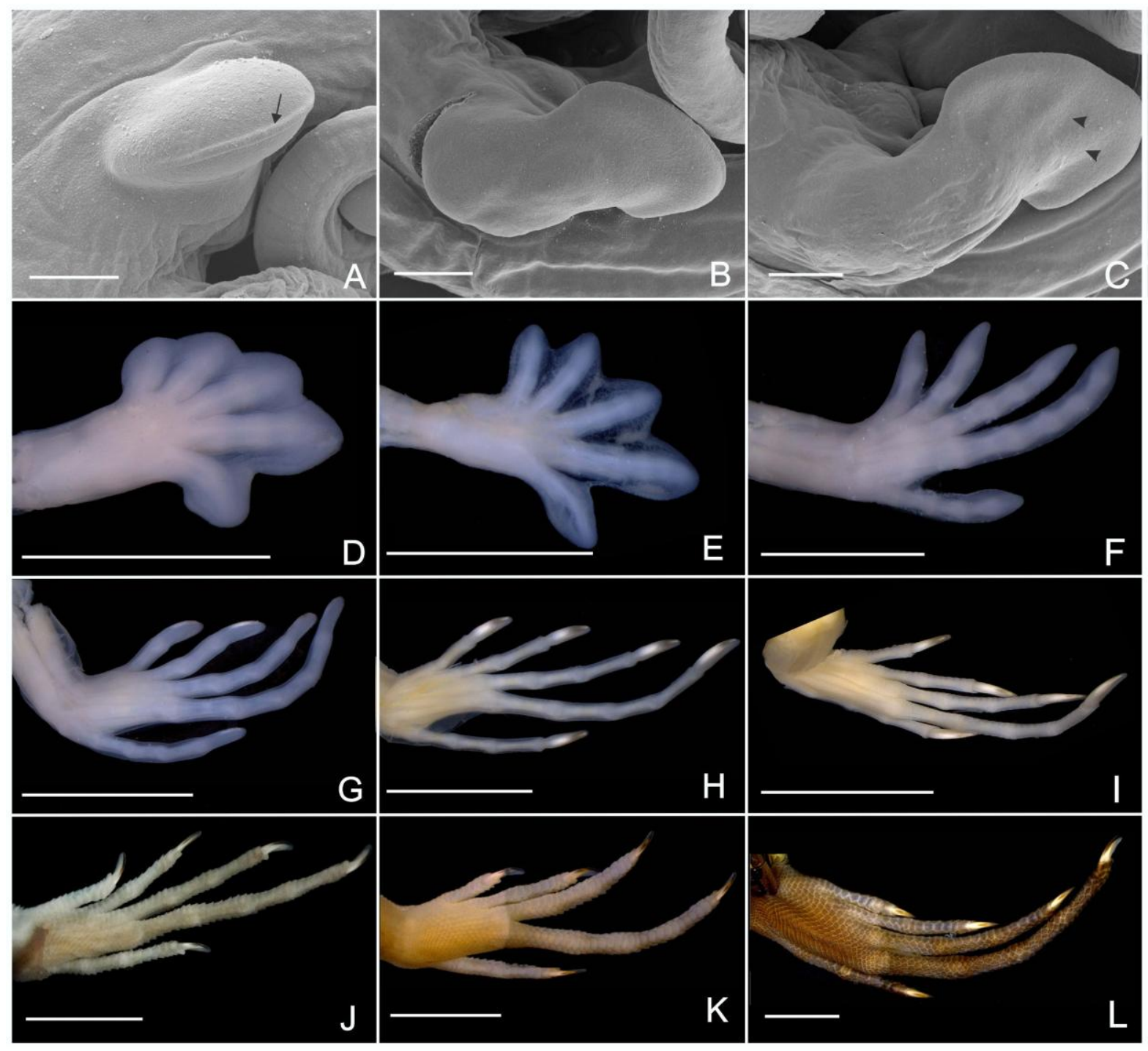

Figura 31: Sequência de desenvolvimento do membro pelvino em embriões de I. iguana iguana. Microscopia eletrônica de varredura do broto do membro nos estágios 28 (A), 29 (B) e 30 (C). Em A é possível observar a presença da crista apical (seta) e em C o primórdio dos artelhos na superfície da placa digital (cabeça da seta). Barra $300 \mu \mathrm{m}$. Fotografias nos estágios 31 (D), 32 (E), 33 (F), 34 (G), 36 (H), 38 (I), 41 (J), 43 (K) e 44 (L). Barra: 1 mm.

Estágio 42 - Presença marcante de escamas pigmentadas e proeminentes na porção dorsal do tronco. Coloração se intensifica e o tamanho dos embriões aumenta. Primeira visualização do dente de ovo (Figs. 29, 30, 31 e 32K). 
Estágio 43 - Presença de escalas bem desenvolvidas dispersas por todo o corpo. Coloração cinza escuro marcada por faixas claras. Formação dos dentes na mandíbula e maxila (Figs. 29, 30 e 31).

Estágio 44 - Embriões com Pigmentação da pele e olhos, escamas pelo corpo, parede corporal fechada. Olhos fechados e pouco vitelo residual. Narina aberta. Aspecto adulto (Figs. 29, 30 e 31, 32L).

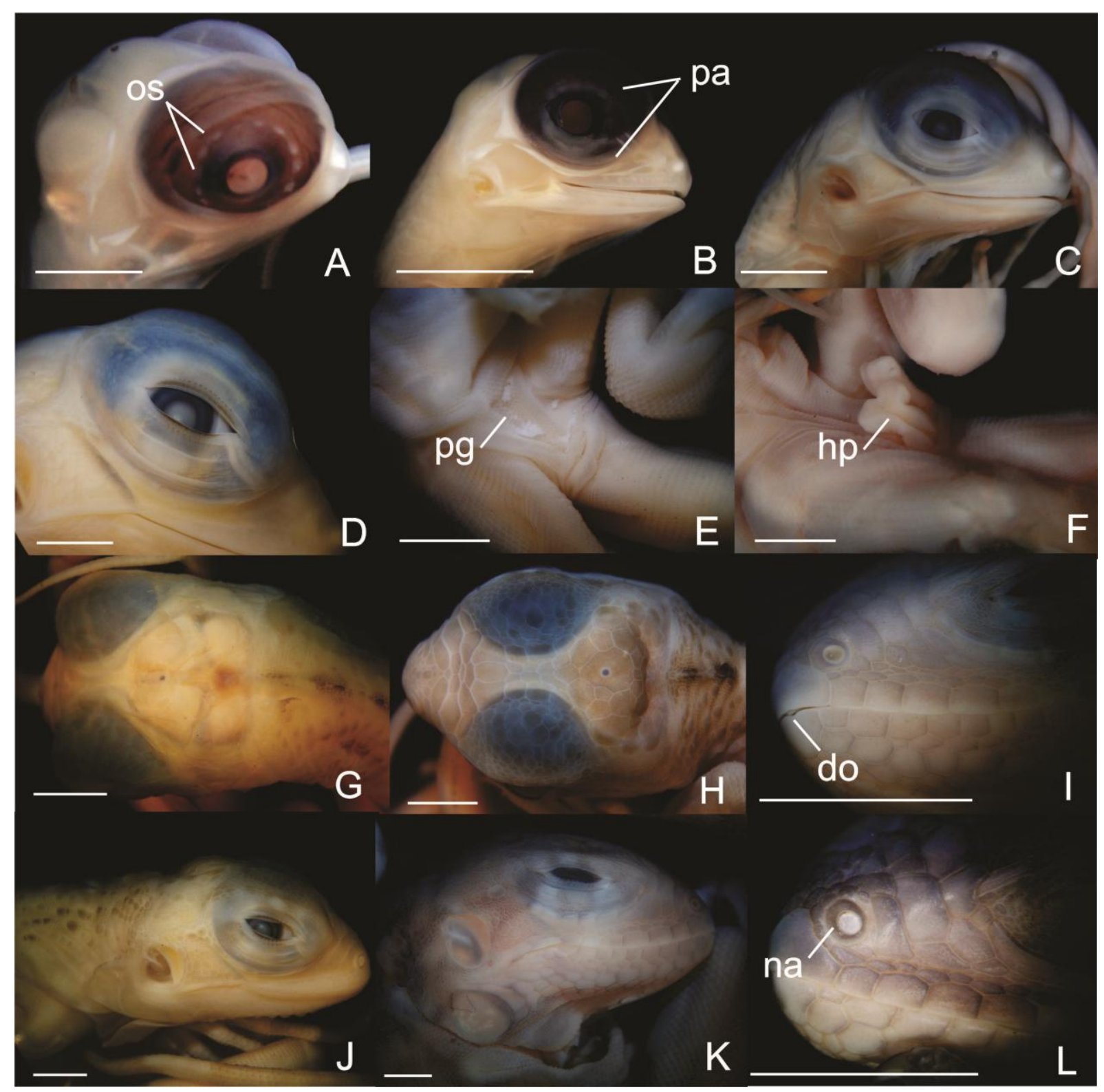

Figura 32: Detalhes da sequência de desenvolvimento em embriões de I. iguana iguana. A; estágio 37. B; estágio 38. C; estágio 39. D; estágio 44. E; estágio 37. F, G e J; estágio 40. H e I; estágio 41. K; estágio 42. L; estágio 44. os, ossículos da esclera; pa, pálpebra; pg, prega genital; do, dente do ovo; na, narina externa. Barra $3 \mathrm{~mm}$. 
Tabela 1. Relação de dias de desenvolvimento in ovo por estágio, número de embriões analisados e características chaves de cada estágio.

\begin{tabular}{|c|c|c|c|}
\hline Estágio & Dias & $\begin{array}{c}\text { N. de } \\
\text { embriões } \\
\text { analisados }\end{array}$ & Principais características \\
\hline 28 & $1-2$ & 9 & $\begin{array}{l}\text { Brotos dos membros (torácico maior que o pelvino); processo maxilar; } \\
\text { quatro arcos faríngeos, fossa ótica, } 36 \text { pares de somitos, coração } \\
\text { tubular, lente do cristalino. }\end{array}$ \\
\hline 29 & 3 & 6 & Seis arcos faríngeos; fossa nasal, 38 pares de somitos. \\
\hline 30 & 4 & 6 & $\begin{array}{l}\text { Disco digital membro torácico, internalização dos arcos faríngeos, } \\
\text { fechamento do tubo neural. }\end{array}$ \\
\hline 31 & 5 & 6 & Formação do cotovelo, processo nasal, pigmentação íris. \\
\hline 32 & $6-8$ & 12 & Formação do joelho, poro genital, primórdio dos dígitos. \\
\hline 33 & $9-12$ & 16 & $\begin{array}{l}\text { Arcos faríngeos fundidos; processo maxillar rostralmente a margem do } \\
\text { olho; placa digital formada, membros torácicos e pelvinos } \\
\text { equivalentes em tamanho, olho pineal. }\end{array}$ \\
\hline 34 & $14-16$ & 5 & $\begin{array}{l}\text { Pigmentação do olho; membrana digital no membro pelvino; pálpebra } \\
\text { superior. }\end{array}$ \\
\hline 35 & $17-18$ & 3 & Membrana digital no membro torácico, boca fechada. \\
\hline 36 & $20-22$ & 5 & $\begin{array}{l}\text { Dígitos formados; redução da membrana digital; pálpebra inferior, } \\
\text { mandíbula e maxila do mesmo tamanho. }\end{array}$ \\
\hline 37 & $24-26$ & 6 & $\begin{array}{l}\text { Ausência de membrana digital; órgão genital proeminente; aumento no } \\
\text { tamanho do corpo; pigmentação do membro torácico. }\end{array}$ \\
\hline 38 & $28-34$ & 8 & $\begin{array}{l}\text { Pálpebra inferior e superior ultrapassam as papilas esclerais, e se } \\
\text { aproximam da íris. Surgimento de pigmentos na cauda, dorso e } \\
\text { cabeça. }\end{array}$ \\
\hline 39 & $35-40$ & 11 & $\begin{array}{l}\text { Narinas; garras nos artelhos; escamas na cauda, membrana timpânica; } \\
\text { escamas nos membros torácicos; garras nos membros torácicos. }\end{array}$ \\
\hline 40 & $42-46$ & 3 & Genitais dentro do poro genital. \\
\hline 41 & $48-52$ & 6 & $\begin{array}{l}\text { Intensificação da pigmentação do corpo; escamas na cabeça, pálpebras e } \\
\text { dorso, aumento do tamanho corporal. }\end{array}$ \\
\hline 42 & $54-62$ & 8 & Escamas proeminentes e pigmentadas no dorso, dente de ovo. \\
\hline 43 & 64 & 2 & Pigmentação escura com listras claras; formação dos dentes. \\
\hline 44 & $66-70$ & 4 & Pigmentação aspecto adulto; olhos fechados, narina aberta. \\
\hline
\end{tabular}




\subsection{ONTOGENIA DO ESQUELETO}

\section{Crânio}

\section{Dematocrânio}

Premaxila (pm) - apresenta centro de ossificação corado pela primeira vez no estágio 38, quando outros ossos da região rostral do crânio encontram-se bastante desenvolvidos. No estágio 39 é possível averiguar a presença de um centro de ossificação independente na parte palatal do focinho que irá formar o processo incisivo (Fig. 36). A estrutura principal do premaxila neste estágio exibe um proeminente processo dorsocaudalmente direcionado entre ambas as placas do osso nasal. No final do estágio 39 o processo incisivo está fundido ao componente principal do osso formando uma peça única que ainda não contata outros elementos ósseos. No estágio 41 contata o maxila, no 42 o nasal e no estágio 44 o vômer (Figs. 33-35).

Septomaxila (sp) - no estágio 38 pode ser detectada a partir de uma inconspícua mancha corada no embrião. No inicio deste estágio está evidente e pode ser observado como um par de manchas irregulares lateralmente dispostas a cápsula nasal. No estágio 40 possui formato similar aquele descrito no esqueleto adulto, posicionado entre o osso nasal, o processo nasal do premaxila e o vômer (Fig. 36).

Maxila (ma) - este é um dos primeiros elementos a iniciar sua ossificação em Iguana iguana iguana, formando inicialmente a borda labial. No final do estágio 36 está presente como uma estreita faixa alongada rostrocaudalmente na margem superior da cartilagem mandibular. No estágio 38 a borda labial está bem corada e a ossificação avança dorsalmente formando a maior parte do corpo do osso. Seu aspecto é triangular no estágio 39, com a extremidade afilada direcionada caudalmente contatando a extremidade maxilar do jugal e rostralmente sua borda limita a margem ventrolateral da abertura nasal. Dentes maxiliares estão presentes no estágio 38. No estágio 41 ele é amplo tal como no adulto e a densidade de coloração indica um grande processo de mineralização. Neste estágio ele contata os ossos premaxila, nasal, pré-frontal, lacrimal, jugal, palatino, ectopterigóide e vômer (Figs. 33-35).

Nasal (na) - No embrião do estágio 36 ele está presente porém não corado. É possível observar a diferença de textura do material com auxílio de aumento. Nos demais estágios até final do 38 ele não está presente nos embriões avaliados, estando corado apenas estágio 39. Cada uma das placas dispostas rostralmente no focinho são quadrangulares e repousam acima da capsula nasal, não contatando nenhuma outra estrutura ossificada neste 
estágio. No estágio 41 ambas as placas apresentam formato mais alongado que em estágios anteriores e contam, por meio de sua margem lateral, o pré-frontal e maxila. Na linha mediana exibem uma borda curva que contata seu contralateral apenas na parte caudal, limitando uma fontanela nesta região com o osso frontal, ainda em desenvolvimento. Possui morfologia similar aos adultos no estágio 42, embora ainda não se contatam amplamente na linha mediana ou ao processo nasal do premaxila. No estágio 43 o desenvolvimento da parte rostral avança e envolve completamente o processo nasal do premaxila. Somente no embrião do estágio 44 está conspícuo o contado na linha mediana entre ambas as placas (Figs. 33, 34 e 36).

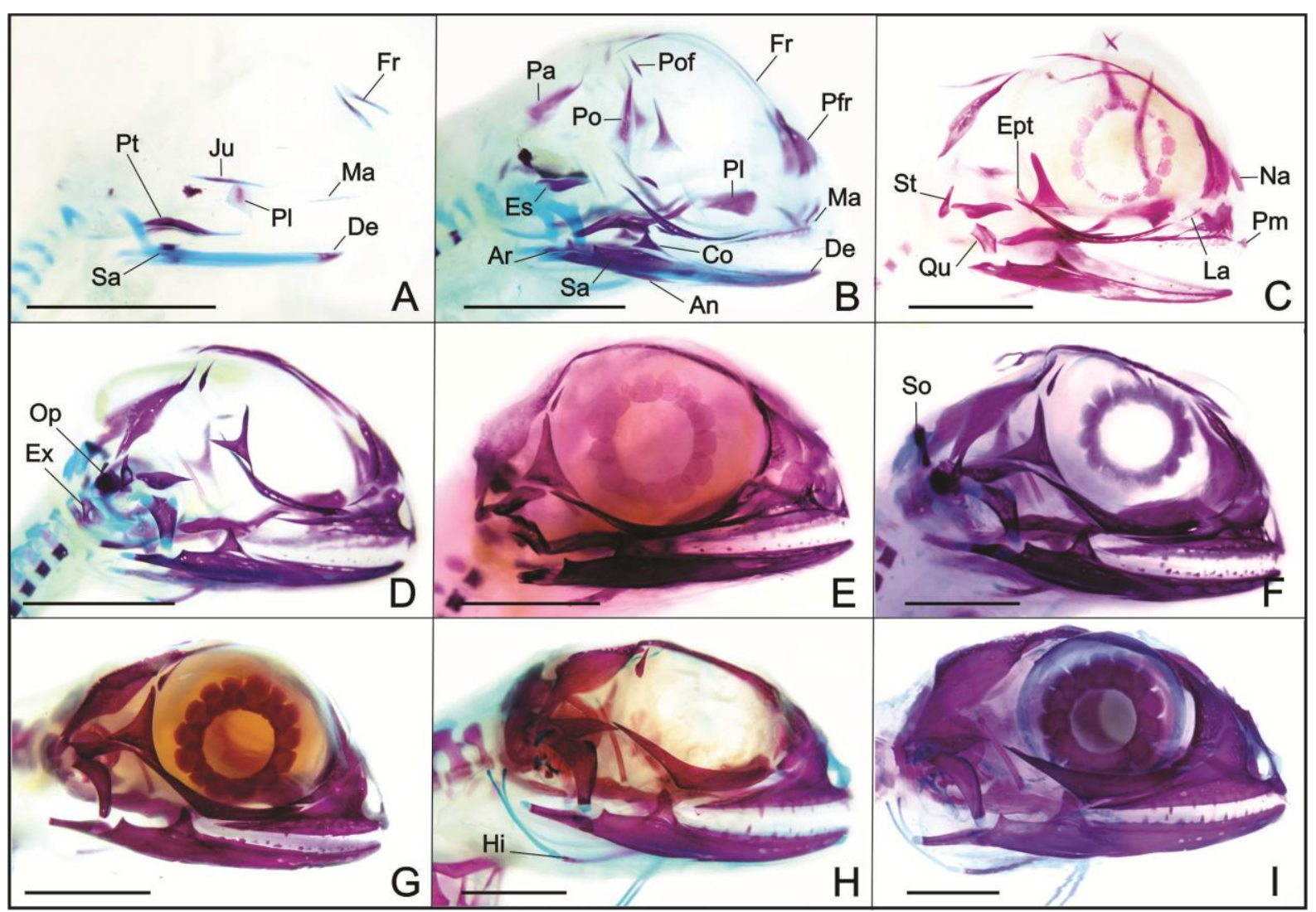

Figura 33: Sequência de desenvolvimento do crânio em embriões de I. iguana iguana. Vista lateral. A, estágio 36; B e C, estágio 37; D, estágio 38; E, estágio 39; F, estágio 40; G, estágio 41; H, estágio 42; I, estágio 44. An, angular; Ar, articular; Co, coronóide; De, dentário; Ept, epipterigóide; Es, esquamosal; Ex, exoccipital; Fr, frontal; Hi, hióide; Ju, jugal; La, lacrimal; Ma, maxila; Na, nasal; Op, opstótico; Pa, parietal; Pfr, pré-frontal; Pl, palatino; Pm, prémaxila; Po, pós-orbital; Pof, pós-frontal; Pt, pterigoide; Qu, quadrado; Sa, suprangular; So, supraoccipital; St, supratemporal. Barra $5 \mathrm{~mm}$. 
Pré-frontal (pfr) - visualizado nos embriões do estágio 38 (não visualizado no 39) e nos demais a partir do estágio 40, o pré-frontal está corado na parte pré-orbital do crânio. No embrião do estágio 38 uma conspícua placa triangular está em destaque no crânio de I. iguana iguana. Com sua porção central bem corada e bordas mais claras este elemento apresenta pouca variação na morfologia durante a ontogenia. No estágio 42 está bem evidente na parte rostral da órbita definindo a forma adulta (Figs. 33 e 34).

Lacrimal (la) - o osso lacrimal em I. iguana iguana trata-se de uma pequena placa que se forma a partir do estágio 39. Pode ser visualizado neste período como uma diminuta placa pobremente corada com vermelho de alizarina na margem rostral lateral da órbita. Possui formato alongado caudalmente exibindo uma espícula que se projeta em direção ao osso jugal. No estágio 40 ocupa uma área relativamente extensa em comparação aos estágios anteriores, contatando os ossos pré-frontal, jugal e maxila. Seu formato quadrangular, similar ao adulto pode ser observado no estágio 42 e a partir deste até o final do período de incubação o lacrimal não sobre modificações em sua morfologia (Figs. 33 e 36).

Frontal (fr) - observado no embrião de 24 dias (estágio 37). Inicia seu desenvolvimento a partir da ossificação de duas estreitas e alongadas placas dispostas na parte dorsal do crânio, na margem orbital. O crescimento da placa ocorre inicialmente no sentido rostro-caudal, evidenciado pelo formado afilado e ainda pouco desenvolvido lateromedialmente no estágio 40. No estágio 41 ambos os centros de ossificação exibem projeções que direcionam-se a linha mediana, mantendo porém, uma grande distância entre as placas, principalmente na região rostral. A parte caudal da placa possui uma curvatura que direciona a espícula caudal lateralmente, contatando o centro de ossificação do parietal, pósfrontal e pós-orbital. Somente no estágio 44 é possível notar a fusão das placas do frontal formando um elemento único. A borda caudal exibe um formado levemente côncavo contatando o parietal por meio de suas extremidades laterais, limitando rostralmente a fontanela craniana, que permanece aberta até a eclosão. Neste período ambas as extremidades da parte rostral do osso permanecem ainda separadas lateralmente e contatam o processo frontal do osso pré-frontal lateralmente e uma pequena parte desta extremidade contata também o osso nasal, permanecendo a área mediana entre eles ainda sem ossificação (Figs. 33 e 34). 


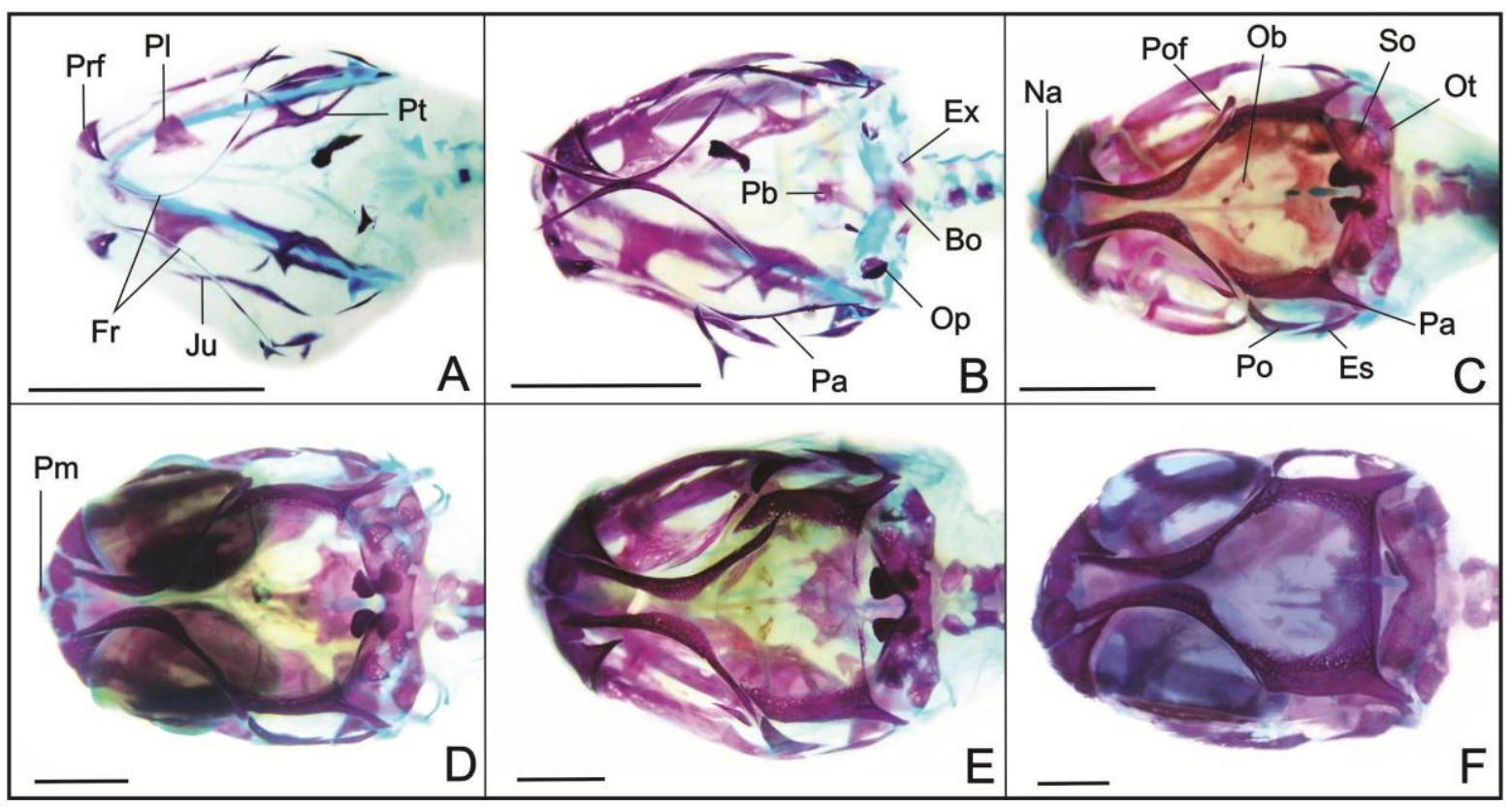

Figura 34: Sequência de desenvolvimento do crânio em embriões de I. iguana iguana. Vista dorsal. A, estágio 37; B, estágio 38; C, estágio 39; D, estágio 40; E, estágio 41; F, estágio 42. Bo, basioccipital; Es, esquamosal; Ex, exoccipital; Fr, frontal; Ju, jugal; Na, nasal; Ob, orbitoesfenóide; Op, opstótico; Ot, otoccipital; $\mathrm{Pa}$, parietal; $\mathrm{Pb}$, parabasesfenóde; Pfr, préfrontal; Pl, palatino; Pm, pré-maxila; Po, pós-orbital; Pof, pós-frontal; Pt, pterigoide; So, supraoccipital. Barra $5 \mathrm{~mm}$.

Parietal (pa) - pode ser discretamente visualizado a partir do estágio 38. Inicia sua ossificação por meio de dois centros distintos dispostos lateralmente na região do teto craniano. Inicialmente as placas são alongadas no sentido rostro-caudal e sua borda lateral é bem definida, contatando o processo parietal do frontal, o pós-frontal, pós-orbital e caudalmente o esquamosal. A borda medial é irregular e formada por espículas oriundas do processo de expansão intramenbranosa do osso. No estágio 39 o centro de ossificação está nitidamente marcado com vermelho de alizarina, embora sua morfologia não seja diferente daquela relatada para o estágio anterior. No estágio 42 os centros de ossificação encontram-se ainda restritos à borda lateral do teto craniano. A partir do contato cranial com o processo parietal do osso frontal fica delimitada a grande fontanela craniana, que ocupa toda a parte dorsal do crânio. Até o estágio 43 apenas as bordas laterais do crânio estão limitadas pelo parietal. A ossificação avança em sentido mediano e caudal, contatando o osso suproccipital, que limita caudalmente a fenestra craniana. No estágio 44 a referida fenestra é conspícua na superfície dorsal do crânio, permanecendo ambas as placas do parietal distintas durante todo o 
período embrionário. Sua fusão ocorre no período pós-natal, haja vista que este corresponde em um elemento único em lagartos adultos (Figs. 33 e 34).

Supratemporal (st) - está presente como uma estrutura corada pela primeira vez no estágio 38, embora de maneira discreta. Ao final do estágio 38 é facilmente visualizado na face laterocaudal do crânio, ventral ao parietal e caudal ao esquamosal. Forma-se por meio de um centro de ossificação único e pequeno para cada osso, com forma alongada. No estágio 40 possui bordas bem definidas e posição similar ao adulto. Desenvolve-se rapidamente, permanecendo quase inalterado a partir do estágio 41. No estágio 44, com o avanço do desenvolvimento dos demais elementos ósseos desta região, o supratemporal representa apenas uma diminuta placa intrincada entre os ossos parietal, esquamosal, quadrado e otoccipital, na região caudal do crânio (Figs. 33 e 36).

Pós-frontal (pof) - trata-se de um pequeno elemento ossificado na borda dorsocaudal da órbita. No estágio 38 é possível observar sua formação a partir da discreta retenção de corante. No estágio 39 este é conspícuo, sendo facilmente destacado da margem orbital, haja vista não apresentar contato com nenhum outro elemento nesta fase do desenvolvimento. Seu centro de ossificação é pequeno e em forma de lança e pouco se desenvolve a partir deste formato. Ao estágio 40 está bem destacado e contata o processo frontal do parietal, limitando a margem orbital. Com o avanço do processo de ossificação do crânio ele torna-se bem discreto, quase sobreposto pelo osso parietal e continuo ao processo parietal do frontal, repousando dorsalmente ao processo dorsal do pós-orbital (Figs. 33 e 36).

Pós-orbital (po) - este osso é um dos primeiros a iniciar se processo de ossificação. No estágio 36 e também no embrião do estágio 37 é possível notar seu desenvolvimento que, no embrião do estágio 38 é observado com menor retenção de corante, embora ainda bem destacado na face lateral do crânio. Corresponde em uma placa trirradiada caudal a órbita. Sua base ventralmente posicionada possui bordas onduladas e pouco marcadas com corante no estágio 38. Seu ápice, dorsalmente disposto, direciona-se a região onde, no adulto, encontram-se o parietal, frontal, pósfrontal e o referido pós-orbital. Aos 60 dias (estágio 42) suas margens rostral, caudal e ventral estão completamente delineadas e sua posição corresponde ao adulto (Figs. 33 e 34).

Esquamosal (es) - discretamente visível no embrião do estágio 38, e claramente observado no estágio 39, o esquamosal desenvolve-se por meio de um processo de ossificação alongado no sentido rostro-caudal, repousando sobre a cartilagem quadrada. No estágio 40 ele possui bordas definidas e esboço similar ao osso adulto. Contata a base do osso pós-orbital, o processo caudal do jugal, o supratemporal e, neste estágio, o já ossificado osso quadrado. No 
estágio 42 ele exibe um proeminente e afilado processo rostral, permanecendo até o embrião do estágio 44 com morfologia similar. Nos estágios finais é possível notar apenas a intensificação da marcação pelo corante vermelho de alizarina e suas relações topográficas com as estruturas adjacentes. (Figs. 33, 34 e 36).

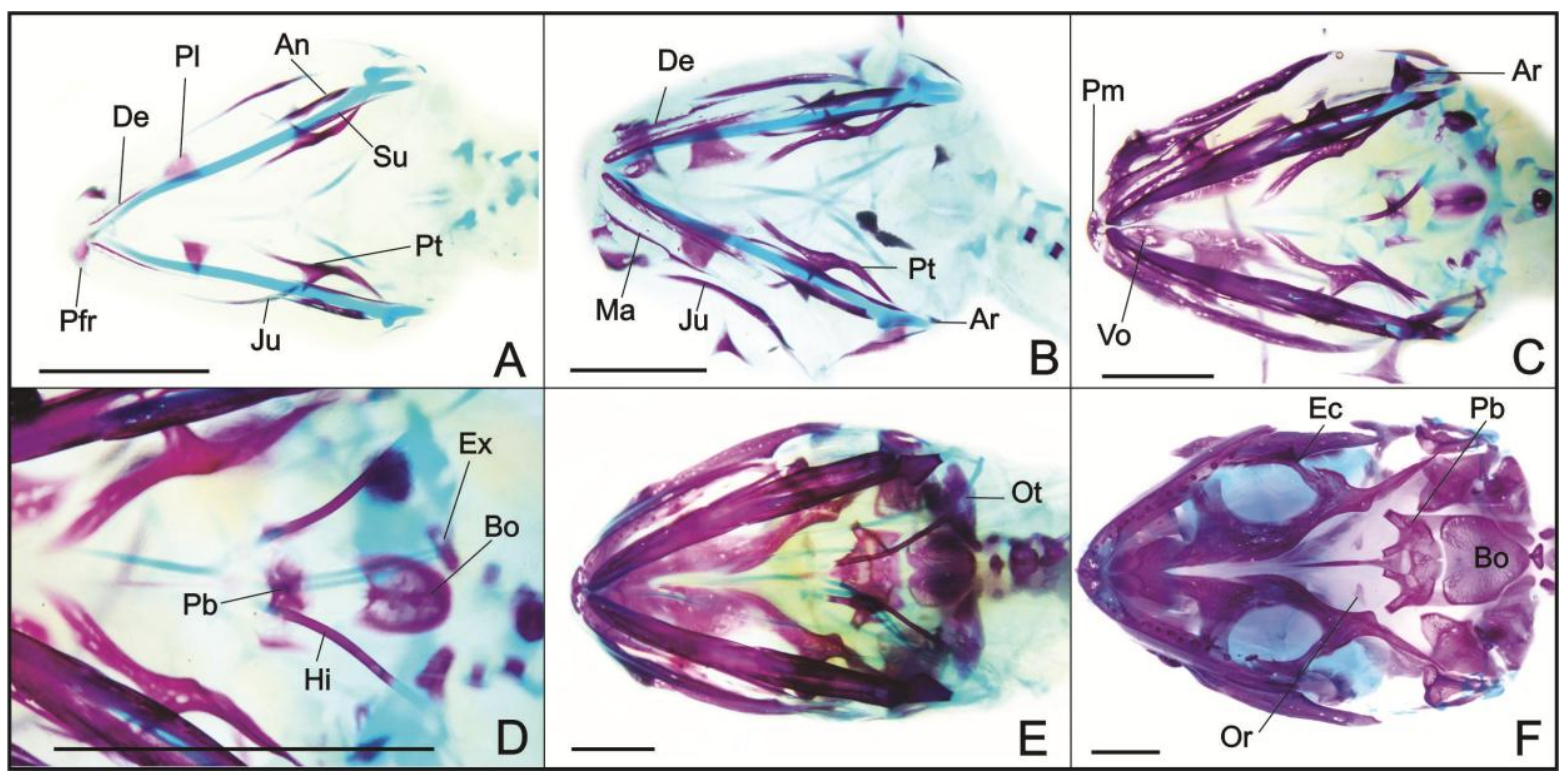

Figura 35: Sequência de desenvolvimento do crânio em embriões de I. iguana iguana. Vista ventral. A, estágio 36; B, estágio 38; C e D, estágio 39; E, estágio 41; F, estágio 43 (sem mandíbula). An, angular; Ar, articular; Bo, basioccipital; De, dentário; Ec, ectopterigóide; Ex, exoccipital; Hi, hióide; Ju, jugal; Ma, maxila; Or, orbitoesfenóide; Ot, otoccipital; Pb, parabasesfenóide; Pfr, pré-frontal; Pl, palatino; Pm, pré-maxila; Pt, pterigoide; Sa, suprangular; Vo, vômer.Barra $6 \mathrm{~mm}$.

Jugal (ju) - apresenta-se como uma alongada placa em forma de espícula arqueada e bem corada no embrião de 22 dias (estágio 36). Em um dos espécimes de 25 dias avaliado (estágio 37) ele está menos evidenciado pela coloração. Nos demais embriões a marcação é observada com facilidade. No estágio 38 dias o jugal é a formação mais evidente em vista lateral, posicionado entre o focinho e a parte orbital do crânio, exibindo uma margem côncava dorsalmente. Ao estágio 39 ele forma um arco entre o lacrimal e o maxila rostralmente, e o pós-orbital caudalmente. Até o final do período embrionário sua forma não se altera significativamente. No estágio 42 ambas as placas estão visualmente tal como nos indivíduos adultos, limitando a margem ventral da órbita e dispostas entre o maxila e o pós-orbital (Figs. 33-35). 
Vômer (vo) - este foi talvez o elemento que apresentou mais variação entre os embriões jovens. Origina-se por meio de um par de placas ventralmente dispostas na região do palato. No estágio 36 um embrião exibiu uma discreta retenção de corante nestas placas. No estágio seguinte, em nenhum dos embriões o vômer estava corado. Ele foi visualizado novamente apenas nos embriões a partir do estágio 38. As estruturas adjacentes se desenvolvem rápido, o que dificulta a observação do processo de ossificação do vômer nos crânios intactos. No estágio 42 eles estão justapostos mas não existe contato evidente na linha mediana. Caudalmente ele contata o palatino, rostralmente o pré-maxila e lateralmente limita a margem medial da fenestra vomeropalatina.

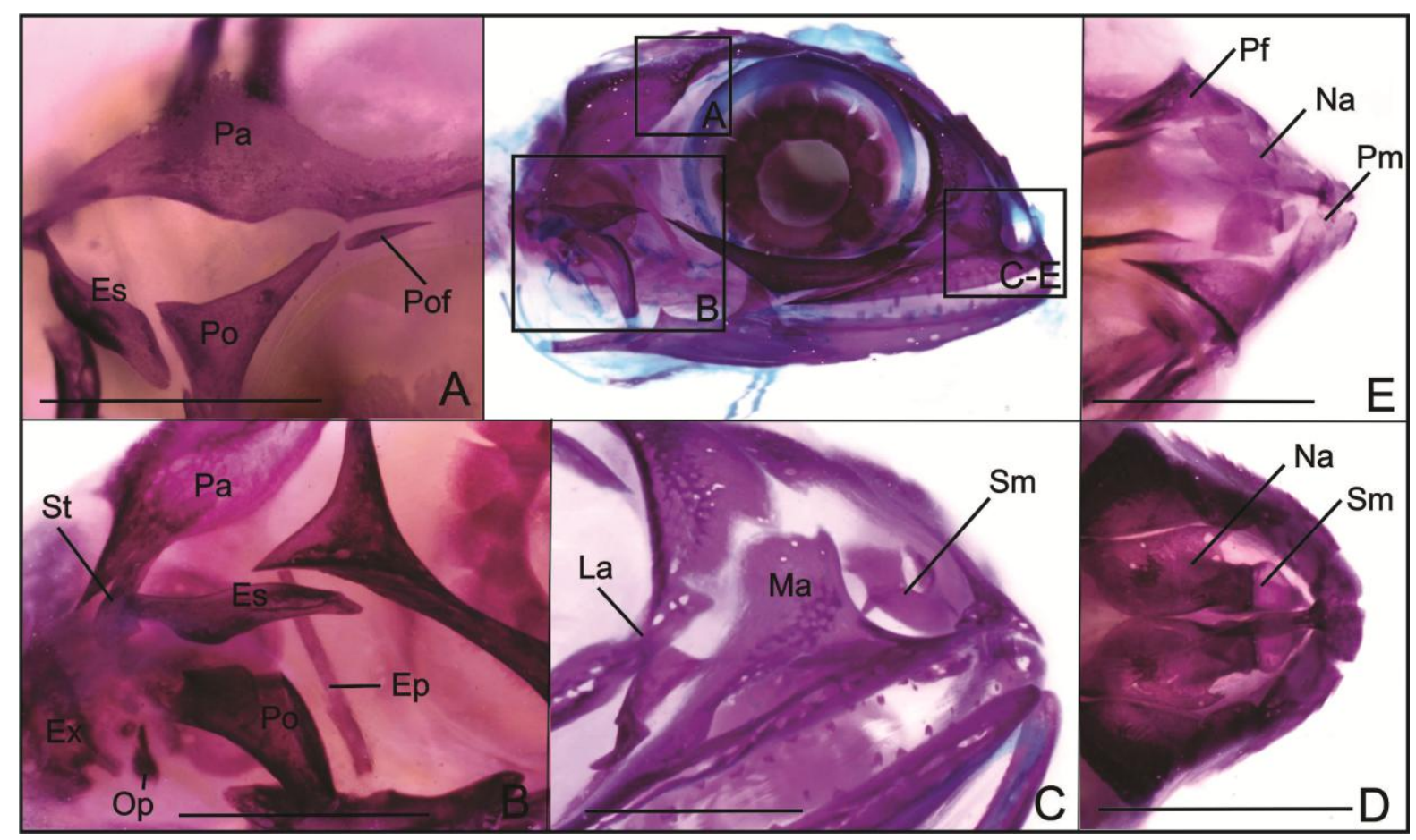

Figura 36: Fotografias de detalhes do desenvolvimento do crânio em embriões de I. iguana iguana. A, estágio 39 evidenciando a topografia do osso pós-frontal. B, estágio 40 em vista lateral da região pós orbital. C e D, estágio 41. Presença da septomaxila (Sm) dentro da cavidade nasal. E, estágio 39 vista dorsal da parte rostral co crânio. Note que o pré-maxila se ossifica por meio de dois centros distintos. Ep, epipterigóide; Es, esquamosal; Ex, exoccipital; La, lacrimal; Ma, maxila; na, nasal; Op, opstótico; Pa, parietal; Pf, pré-frontal; Pl, palatino; Pm, pré-maxila; Po, pós-orbital; Pof, pós-frontal, Sm, septomaxila, St, supratemporal. Barra $5 \mathrm{~mm}$. 
Palatino (pl) - Ambas as placas podem ser discretamente observadas nos embriões de 25 dias (estágio 37). No embrião do estágio 38 elas não estão visíveis, e voltam a observadas no estágio 39. Estão dispostas rostralmente a região orbital ocupando grande parte da porção palatal do focinho. Até o estágio 42 ele se desenvolve e estende-se caudalmente ao nível do terço rostral da região orbital. Não existe contato mediano entre ambas as placas. Uma discreta fissura está presente, tal como no crânio do adulto. Rostralmente ele sutura com o vômer e caudalmente com o pterigoide. Lateralmente ele limita a parte caudal da borda medial da fenestra vomeropalatina (Figs. 33-35).

Ectopterigóide (ec) - trata-se de um centro de ossificação ainda discreto no estágio 38 com relação ao tamanho, porém bem marcado. No estágio 39 ambos os elementos apresentam-se ainda individualizados e não contatam outros ossos no crânio do embrião. No estágio 42 ele articula com o pterigoide e o jugal, estando disposto em sentido vertical unido o arco orbital ventral a região palatal (Figs. 33 e 36).

Pterigóide (pt) - está entre os primeiros elementos a iniciar sua ossificação no crânio de Iguana. No estágio 36 apresenta centro de ossificação corado, que se intensifica no embrião do estágio 37 e 38 . No estágio 38 ele já ocupa grande porção da face palatal. Este elemento conecta-se caudalmente com o neurocrânio por meio de suturas entre o processo quadrado e a placa parabasisfenóide. Três conspícuos processos estão presentes no estágio 41. O processo palatino sutura-se com o osso palatino rostralmente, o processo ventromedial com o ectopterigóide por meio de uma união vertical e o longo processo quadrado que possui forma laminar e direciona-se caudalmente, contatando o osso quadrado. O processo palatino, no estágio 42, exibe uma fileira de dentículos dispostos obliquamente, orientados na crista mediana que segue lateralmente disposta à borda medial do osso. No estágio 44 o pterigoide está bem formado e possui estrutura semelhante ao adulto. Existe uma estreita área preenchida por tecido na parte rostral entre ambos os ossos, na linha mediana. Caudalmente eles se afastam lateralmente e exibem uma grande área livre entre as placas na linha mediana. $\mathrm{Na}$ metade de seu comprimento, ele contata o processo basipterigoide do parabasisfenóide, definindo uma articulação sinovial (Figs. 33-35).

Dentário (de) - inicia seu desenvolvimento cedo em relação aos demais ossos do crânio. No estágio 36 apresenta um centro de ossificação discretamente corado na face lateral da parte rostral da mandíbula. Todos os embriões nos estágios posteriores apresentam o dentário. O centro de ossificação deste elemento ocupa toda a região rostral da mandíbula no estágio 38, envolvendo lateralmente a cartilagem mandubular. No final do estágio 38 seu desenvolvimento caudal é evidente, assumindo um formato triangular com o ápice voltado 
rostralmente. Neste período já estão presentes projeções cônicas que indicam o surgimento dos primeiros dentes mandibulares. Seu formato é similar ao adulto a partir do estágio 41, onde não existe mais evidencia externa da cartilagem mandibular. O contato entre o dentário e os elementos caudais da mandíbula não é evidente, sendo estas estruturas no embrião corado indistinguíveis no estágio 42 (Figs. 33 e 34).

Coronóide (co) - este pequeno elemento localizado aproximadamente na metade do comprimento da mandíbula apresenta-se corado pela primeira vez no estágio 38. Possui um processo dorsal em forma de espícula com ápice arredondado em todos os embriões. A partir do estágio 42 este elemento está suturado a estrutura da mandíbula (Fig. 33).

Suprangular (sa) - tal como o dentário, este elemento inicia sua formação no estágio 36. No embrião do dia 25 (estágio 37) esta estrutura está nitidamente corada na parte caudal dorsal da mandíbula. No estágio 38 o centro de ossificação deste osso é amplo e estende-se por todo o terço distal da mandíbula, lateralmente disposto a cartilagem mandibular. Ele possui um entalhe caudal côncavo onde irá se ossificar o osso articular. Contata o angular no estágio 39 e o dentário no estágio 41. O articular está ossificado e contata o suprangular por meio de sua parte caudal (Figs. 33 e 35).

Angular (an) - este elemento está discretamente corado no embrião do estágio 37. Somente no estágio 38 apresenta retenção de corante evidente. Forma-se por meio de um centro de ossificação alongado no sentido rostrocaudal na parte caudal da mandíbula. No estágio 40 ainda é pouco pronunciado, principalmente em relação ao suprangular que neste período é uma placa ampla na face lateral da mandíbula. No estágio 41 ele apresenta-se bem corado e contata o suprangular, que se destaca na parte dorsal da mandíbula. No estágio 42 sua anatomia representa o padrão adulto, embora não sejam destacadas alterações na forma desde estágios anteriores (Figs. 33 e 35).

Esplenial (ep) - está corado pela primeira vez no estágio 38, onde é ainda discreto ocupando uma pequena parte da face medial da mandíbula. No estágio 40 é possível observar sua forma mais destacada em relação aos estágios anteriores, cobrindo parte da cartilagem mandibular. A face medial da mandíbula é formada em sua maior parte pelo osso esplenial, que no estágio 42 ocupa quase a metade da extensão total, da extremidade rostral ao nível do osso coronóide (Figs. 33 e 35).

\section{Neurocrânio}

Basioccipital (bo) - assim como outros ossos da base craniana e os demais elementos de desenvolvimento endocondral, o basioccipital inicia sua ossificação após os ossos do dermatocrânio. No estágio 38 ele pode ser observado pela primeira vez como uma 
pequena mancha na parte caudal ventral do crânio de Iguana. No decorrer deste estágio o centro de ossificação avança e confere uma forma arredondada a placa, que se forma por meio de um único centro de ossificação. Nesta etapa este elemento possui relação com os demais centros de formação de outros ossos do neurocrânio como o exoccipital e basisfenóide. Nos estágios adiante ele possui uma pequena escavação rostral, permanecendo a margem caudal com formato convexo e contatando lateralmente o osso exoccipital. O neurocrânio não está completamente ossificado no momento da eclosão. As relações físicas tais como as articulações entre estes ossos não estão bem estabelecidas ainda neste período. No estágio 44 o basioccipital não contata o parabasisfenóide, embora sua proximidade seja destacada (Fig. $35)$.

Supraoccipital (so) - presente no embrião do estágio 38 o supraoccipital inicia sua formação por meio da ossificação de dois centros caudalmente dispostos no crânio, medial aos centros de ossificação do exoccipital. Seu desenvolvimento é lento e apenas a partir do estágio 40 é possível observar uma extensa área corada que corresponde a este elemento. No estágio 41 um amplo centro de ossificação em forma de V cobre a extremidade caudal do crânio limitando o forame magno dorsalmente. Seu molde cartilagíneo é evidente em embriões corados com azul de alcian ainda no estágio 42. Apenas no final do estágio 42 é possível descrever a forma adulta deste elemento nos embriões quando ele apresenta-se bem corado e contata os ossos exoccipital. Ao final do período de incubação sua articulação com o parietal, na borda rostral do osso, é reduzida às extremidades laterais deste osso visto o desenvolvimento lento do parietal ainda neste estágio, permanecendo uma pequena fontanela entre estes ossos (Figs. 33 e 34).

Parabasisfenóide (pb) - apenas o molde cartilagíneo deste elemento pode ser observado até o estágio 38. Os centros de ossificação referentes a parte lateral deste osso iniciam sua formação no estágio 38 por meio de discretas manchas coradas com alizarina. No estágio 40 a parte mediana do osso, na parte ventral da base craniana, exibe um conspícuo centro de ossificação. Dois centros de ossificação laterais e um mediano correspondendo, respectivamente, aos ossos lateroefenóide e basisfenóide estão distintos no modelo cartilagíneo apresentado pelo embrião do estágio 41. Com o avanço do desenvolvimento embrionário ocorre o encontro dos centros de ossificação estabelecendo a formação o parabasisfenóide no estágio 42, quando uma única e extensa placa ossificada forma o assoalho craniano, contatando caudalmente o osso basioccipital e projetando rostralmente um pronunciado processo cultriforme, bem ossificado neste estágio (Fig. 35). 
Otoccipital (ot) - nos lagartos o exoccipital e o opstótico são fundidos e formam o otoccipital. No estágio 38 o centro de ossificação de ambos os exoccipital estão presentes. São ligeiramente alongados e lateralmente dispostos ao centro de ossificação do basioccipital. $\mathrm{O}$ opstótico é observado pela primeira vez no estágio 40. Ele se desenvolve por meio de um centro de ossificação para cada osso na parte interna da cavidade craniana. No estágio 40 é conspícuo ambos os pares de placas distintos na parte caudal do crânio. Embora ainda não apresente completo desenvolvimento, no estágio 41 o aspecto deste elemento é similar a morfologia adulta. Ambos os elementos estão fundidos e, nesta fase, o então denominado otoccipital limita a borda lateral do forame magno e a parede lateral e caudal do neurocrânio (Figs. 34 e 35).

Orbitoesfenóide (ob) - corresponde ao elemento do crânio com desenvolvimento tardio em relação aos demais. Apresenta um centro de ossificação discreto para cada elemento no estágio 39. Apenas no estágio 41 é possível observar um incremento em sua forma, quando este apresenta-se como um par de barras lateralmente dispostas ao processo cultriforme, na parede rostral da caixa craniana, na órbita (Fig. 34).

Pró-ótico (pr) - ossifica-se no estágio 39 na parede lateral do neurocrânio por meio de centros de ossificação com formato e número variado. Ao longo da ontogenia estes centros de ossificação se fundem para formar um elemento único em cada antímero e fecham a parte latero-rostral do neurocrânio. No estágio 42 os centros de ossificação se unem em uma placa única que contribui para o formação da anatomia da caixa craniana, contatando os ossos otoccipital, parietal e parabasisfenóide.

\section{Viscerocrânio}

Quadrado (qu) - apenas no estágio 39 é possível observar uma discreta coloração com alizarina presente na placa da cartilagem quadrada. No estágio 40 o processo de calcificação da cartilagem está bastante avançado, o que fica evidente pela impregnação do corante que cora toda parte do corpo do osso, exceto os processos presentes em suas extremidades. Durante a ontogenia a ossificação avança pela placa cartilagínea e sua forma permanece inalterada. No estágio 44 a extremidade ventral, que articula-se com o osso articular da mandíbula, e a extremidade dorsal do osso quadrado, que contata os ossos esquamosal e otoccipital, ainda são formadas pela cartilagem quadrada. Sua completa ossificação ocorre somente após o período embrionário (Fig. 33).

Epipterigóide (ept) - corresponde em uma pequena barra longitudinal localizada lateralmente a caixa craniana, caudal a órbita. Inicia sua ossificação no estágio 39 pela parte 
média de seu modelo de cartilagem, a pila metóptica. Durante seu desenvolvimento apenas ocorre o alongamento da barra óssea no sentido dorso-ventral, contatando no estágio 43 o osso peterigóide. Ele permanece unido ao osso parietal por meio de sua extremidade dorsal cartilagínea. No estágio 44 ele se interpõe entre o teto craniano e o assoalho do palato, formando uma estreita e afilada conexão (Figs. 33 e 36).

Articular (ar) - formado a partir de um modelo cartilagíneo, o osso articular está corado com azul de alcian até o estágio 39, quando apresenta sua primeira marcação com alizarina evidenciando o inicio do processo de ossificação. Localizado na parte caudal da mandíbula, ele forma o processo retroarticular que projeta-se caudalmente, sendo ainda cartilaginoso até o final do período embrionário. No estágio 40 a fossa articular para o osso quadrado está bem marcada, formando uma pequena área côncava na superfície dorsal do osso, exatamente abaixo da cartilagem quadrada. Ele se funde ao insconspícuo centro de ossificação do osso pré-articular ainda no período embrionário formando uma estrutura única no adulto, que contata rostralmente os ossos angular e suprangular (Fig. 33).

Aparato hioide - o único componente do hioide que se ossifica é o basihial. Este possui um modelo cartilagíneo que apresenta centro de ossificação corado pela primeira vez no estágio 39. A mineralização do avança pelo corpo do basihial nas direções caudal e rostral, exibindo no estágio 44 forma de bastão ligeiramente curvado com comprimento aproximado de $1 / 4$ do comprimento da mandíbula (Fig. 33 e 35 ).

Ossículos da esclera - Em todos os espécimes analisados o número de ossículos foi 14. Não houve marcação por azul de alcian confirmando sua formação intramembranosa, tal como evidenciado pela investigação histológica. Apenas no embrião do estágio 36 os ossículos apresentaram-se corados pela primeira vez com vermelho de alizarina (Figs. 37-39).

Por meio de cortes seriados e corados com HE foi possível observar um arranjo diferenciado do mesênquima a partir do estágio 35 (Fig. 39). Existe uma área de condensação bem definida na margem da esclera onde, em estágios posteriores, ocorre a ossificação intramembranosa das placas. É distinto no estágio 38 a migração de células do mesenquima de áreas adjacentes a zona de formação dos ossículos da esclera e a presença de diferenciação em células osteóides outrora, sem efetiva ossificação (Figs. 37-39).

A confirmação da mineralização foi no estágio 39. As zonas de condensação foram marcadas com alizarina e nos embriões diafanizados pode-se perceber a presença dos ossículos. No estágio 40 as placas estavam justapostas e a sobreposição ocorreu a partir do 
estágio 41. Todas as placas possuem formato quadrangular com bordas sinuosas e sua face profunda oferece área de inserção muscular (Fig. 39).

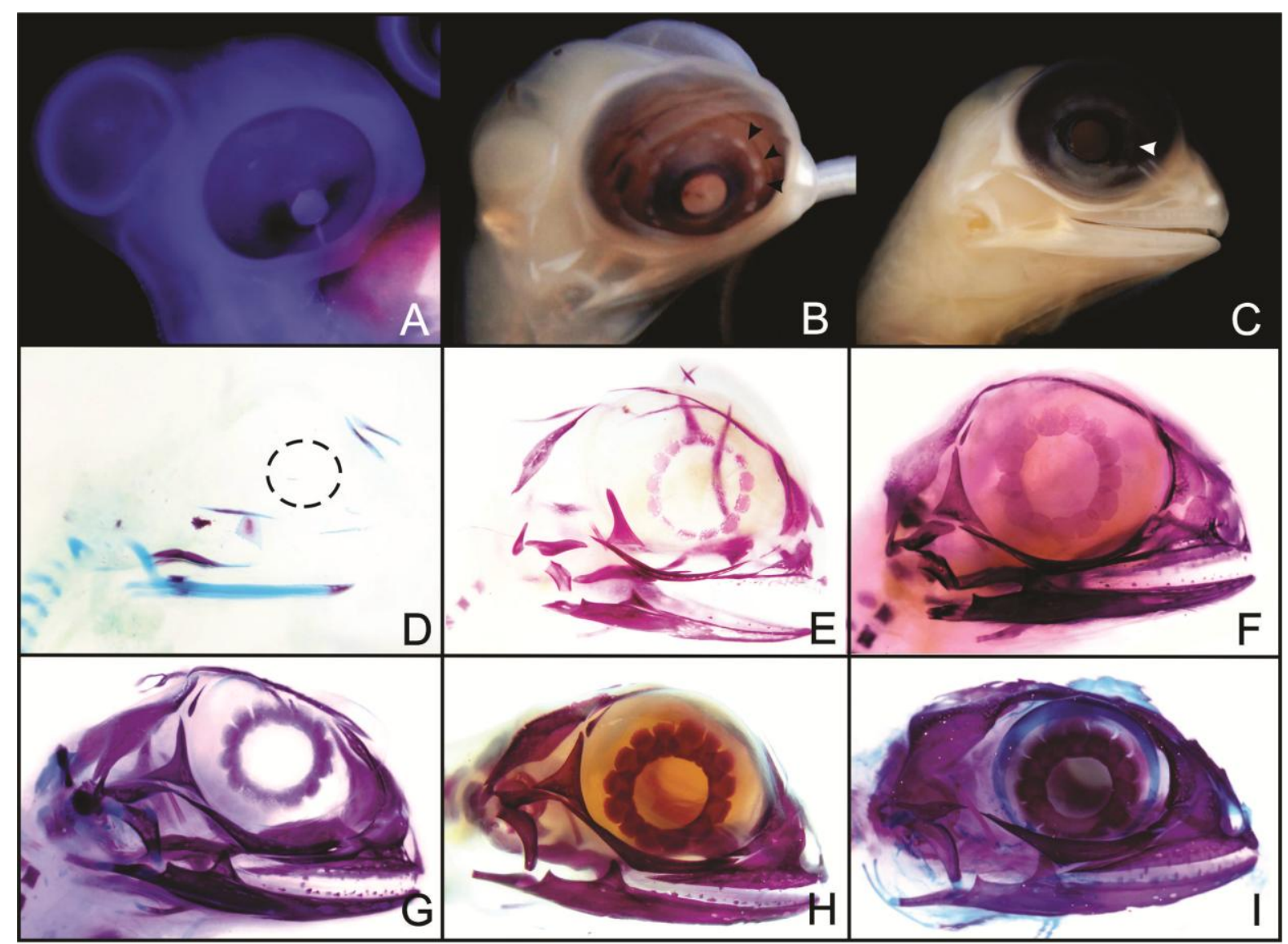

Figura 37: Sequência do desenvolvimento dos ossículos da esclera em embriões de I. iguana iguana. Vista lateral. A, estágio 28. Embora o olho esteja em avançado processo de formação, ainda não existe a presença de ossículos na esclera. B, estágio 37 e C, estágio 38. As cabeças das setas apontam áreas claras onde os ossículos da esclera estão presentes na superfície anterior do olho. em vista lateral da região pós orbital. D, estágio 36. Espécime clareado e corado com Alizarina e Azul de alcian. Neste estágio a formação dos elementos ossificados do olho não é observada pela coloração. E, estágio 38; F, estágio 39; G, estágio 40; H, estágio 41; I, estágio 44. Desenvolvimento dos ossículos da esclera em diferentes estágios. 


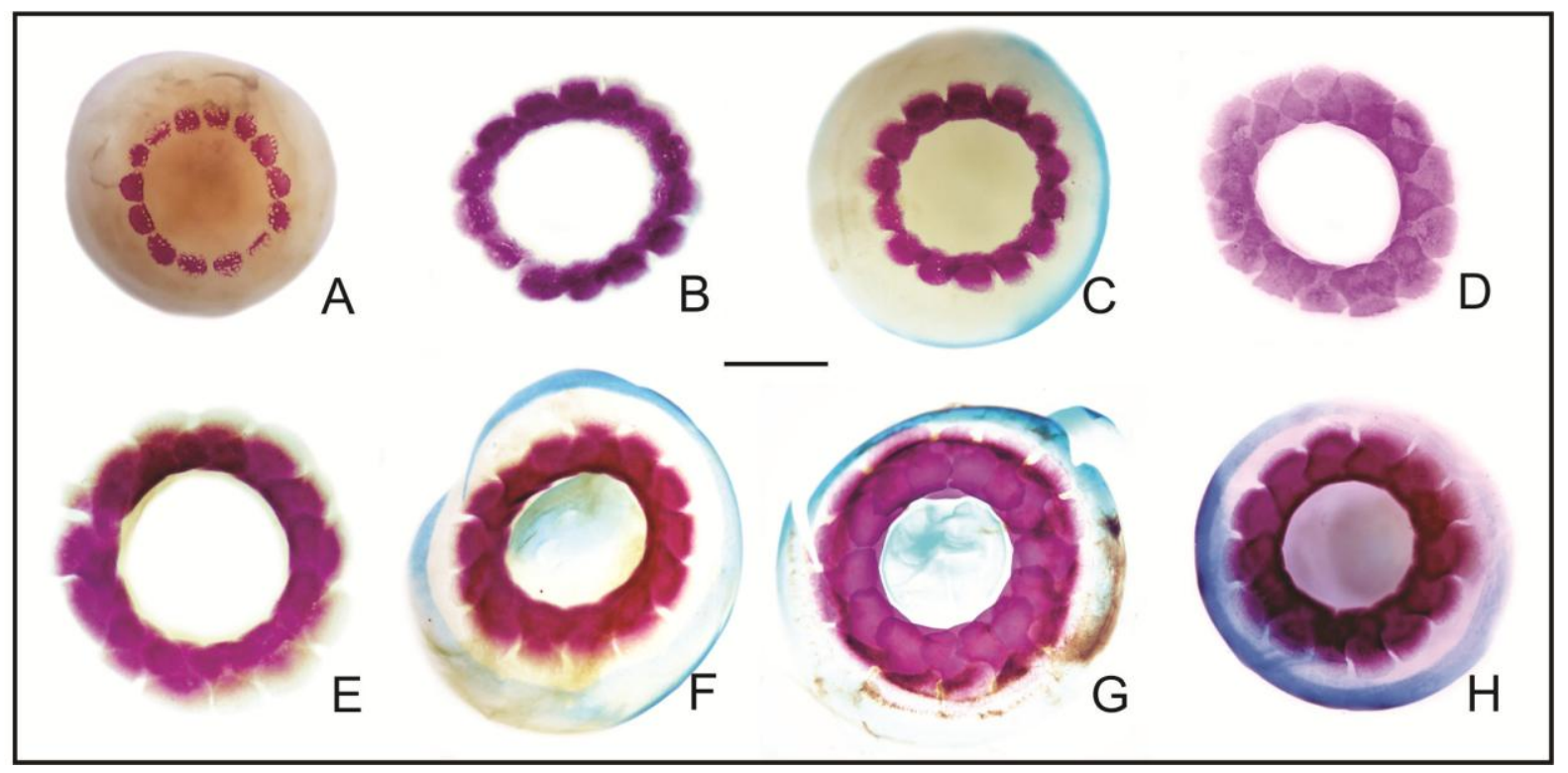

Figura 38: Globos oculares de embriões de I. iguana iguana. As fotografias mostram, em vista rostral, o gradiente de coloração das placas que formam o anel escleral ossificado em iguana. A, estágio 36; B, estágio 37; C, estágio 38; D, estágio 39; E, estágio 40; F, estágio 41; G, estágio 43; H, estágio 44. Barra 2mm. 


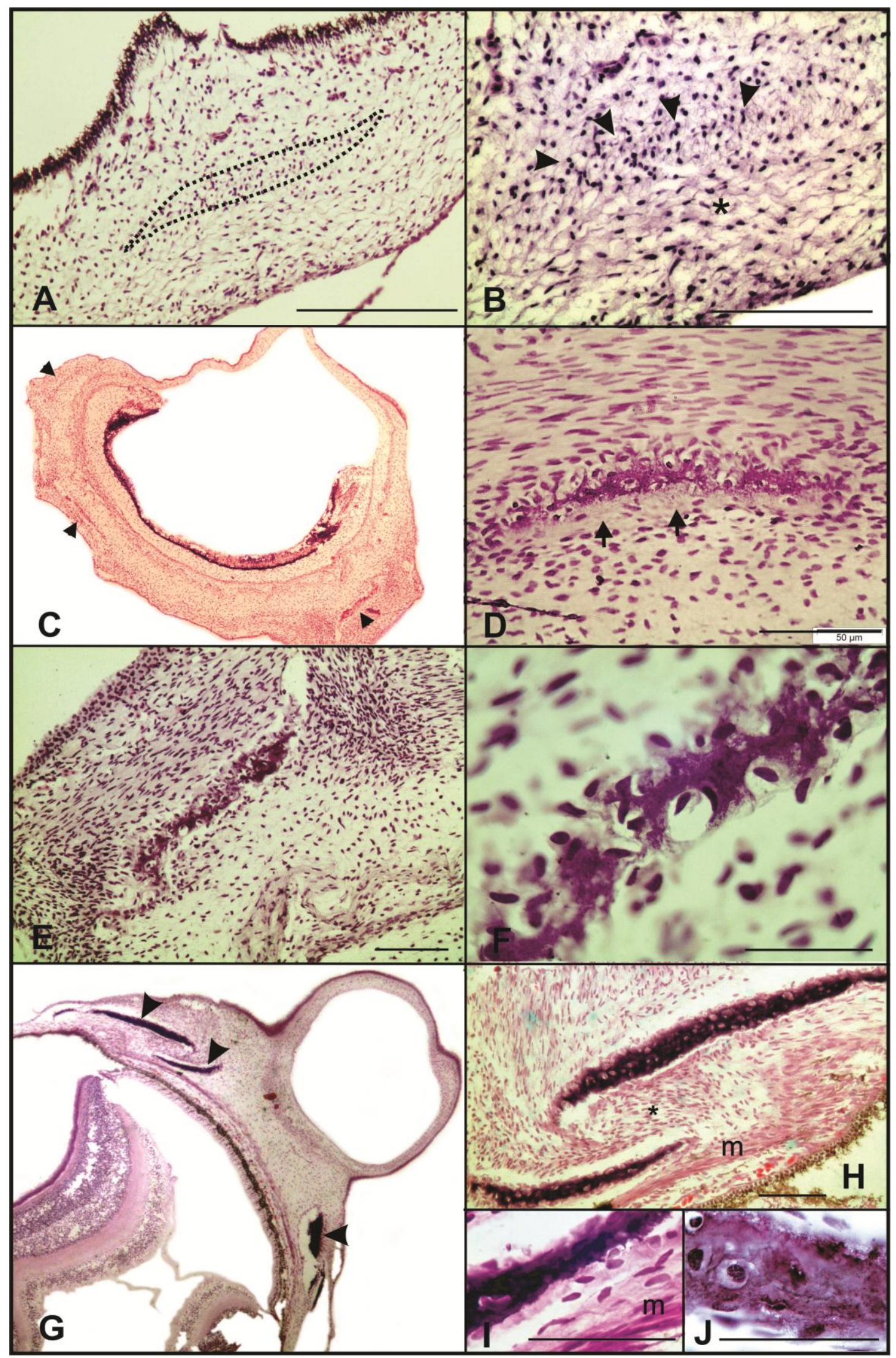

Figura 39: Cortes do globo ocular de embriões de I. iguana iguana. A e B estágio 34. Em A, a área destacada evidencia a zona de condensação referente a formação dos ossículos na esclera do embrião (detalhe em B com aumento marcado pelas cabeças das setas). C, corte 
frontal do olho de iguana no estágio 35. As setas indicam três áreas em avançado processo condensação. D, estágio 36 com a clara presença de tecido mineralizado indicando o início do processo de ossificação. As setas indicam uma faixa de condensação abaixo do tecido ósseo em formação. E e F, estágio 37 nos aumentos 20x e 40x respectivamente. É possível observar a matriz mineral e células ósseas imersas na mesma em uma área relativamente bem delineada. G-I, estágio 40. Em G a fotografia panorâmica do corte transversal do globo ocular permite a identificação dos ossículos da esclera (cabeças das setas) na posição em que ocupam nos espécimes. $\mathrm{O}$ aumento (20x) em H mostra a sobreposição das placas ósseas e a presença de tecido entre ambas (*). No mesmo estágio, com aumento 40x (I) pode-se observar a camada adjacente de tecido muscular na parte inferior do ossículo. K, estágio 43. Detalhe do ossículo da esclera em corte transversal. H.E. Barra $100 \mu \mathrm{m}$.

\section{Vértebras}

Os embriões diafanizados até o estágio 31 apresentam apenas a notocorda. Tal estrutura permanence corada em azul desde a região imediatamente caudal ao crânio até a parte distal da cauda.

Durante o estágio 32 podemos notar centros de formação cartilagínea nas vertebras da parte cranial da coluna vertebral. Não é possível descrever a sequencia em que tais vértebras iniciaram seu desenvolvimento, embora a progressão no sentido crânio-caudal seja conspícua.

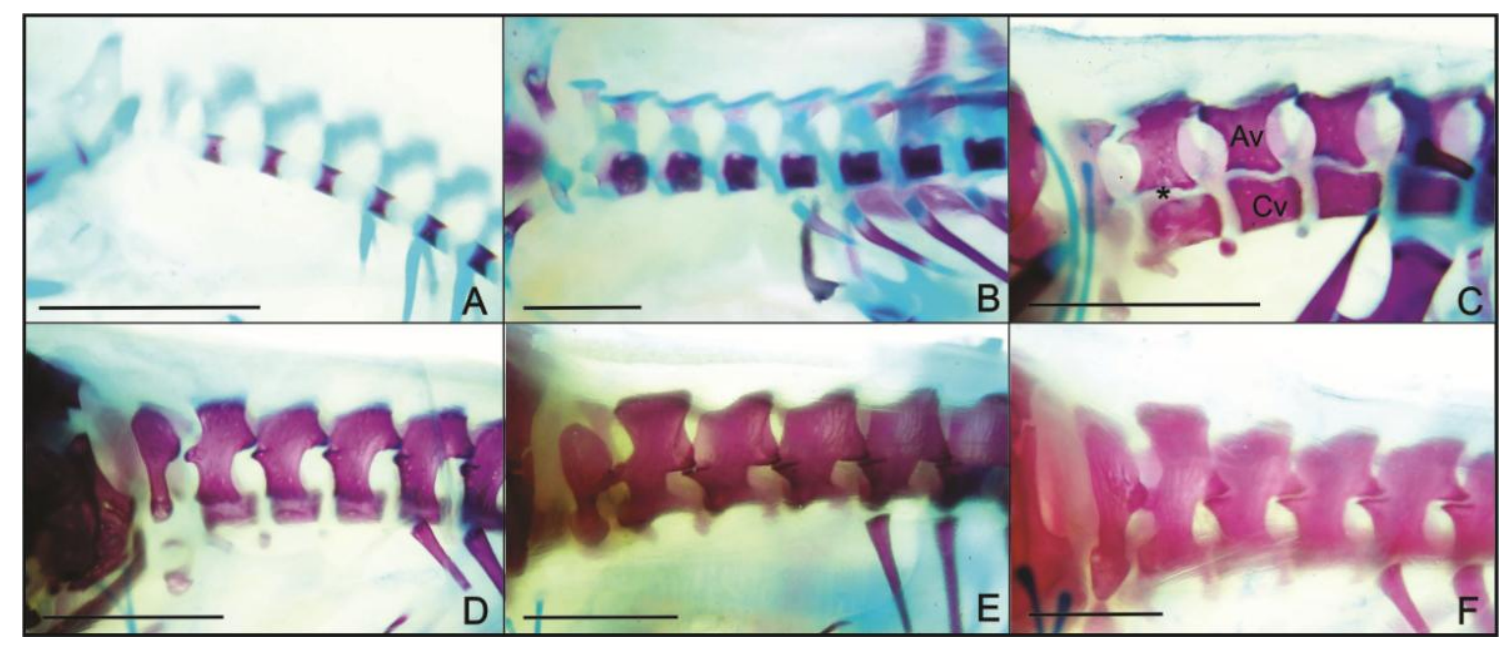

Figura 40: Sequência de ossificação das vértebras cervicais em embriões de I. iguana iguana. A, estágio 37; B, estágio 40; C, estágio 42; D, estágio 43; E, estágio 44; F, embrião de 1 dia pós eclosão. $\mathrm{O}$ * em $\mathrm{C}$ evidencia o contato do corpo vertebral $(\mathrm{Cv})$ e do arco vertebral (Av), ainda não fusionados neste estágio. Barra $5 \mathrm{~mm}$. 
A formação cartilagínea ocorre primeiro nos arcos vertebrais, iniciando-se pela região cervical, dorsal, seguindo para a lombar, sacral e, finalmente a região caudal. Esta estrutura pode ser facilmente observada formando duas barras laterodorsais bem coradas com azul de alcian que, a partir do estágio 35 fundem-se na parte dorsal mediana de maneira a formar um arco. No estágio 37 a condensação cartilagínea torna evidente a forma do corpo vertebral (Figs. 40 e 41).

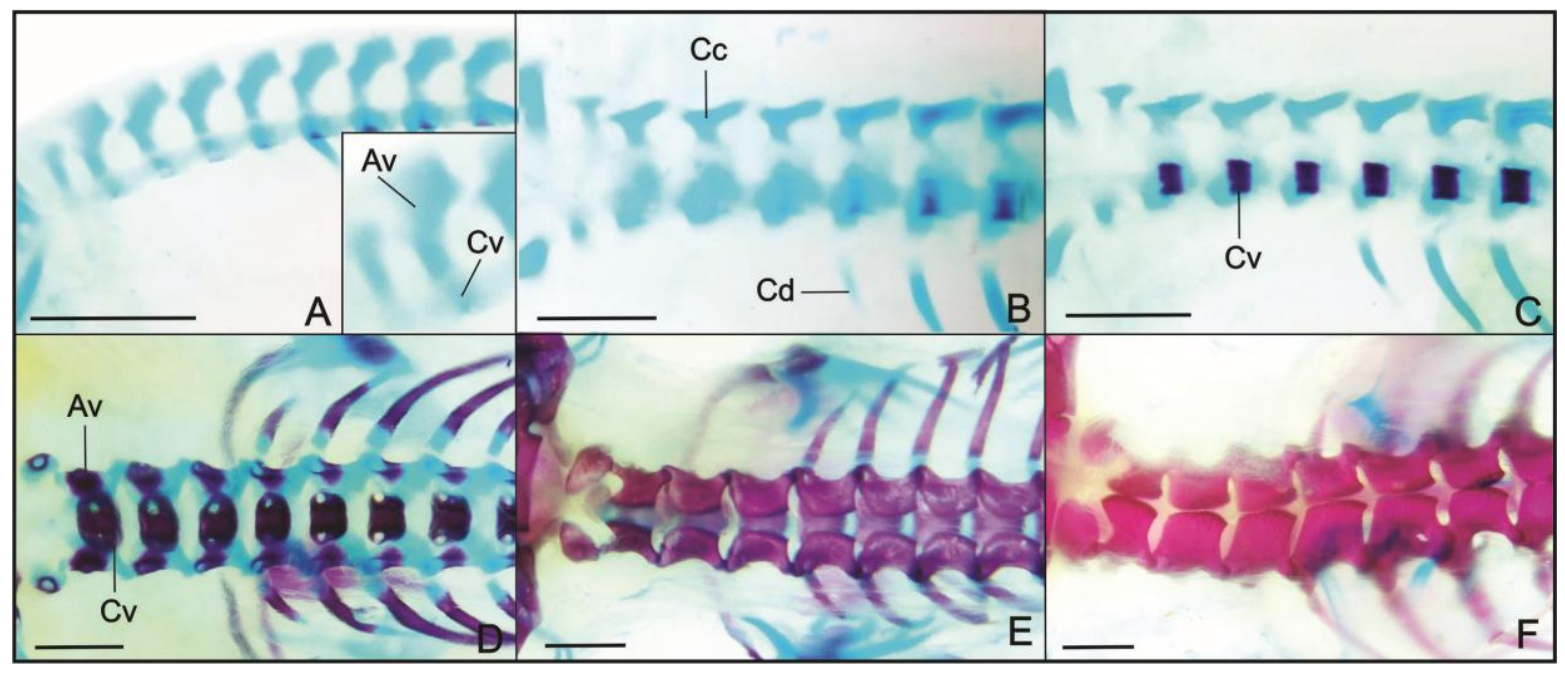

Figura 41: Sequência de ossificação das vértebras em embriões de I. iguana iguana. A e B estágio 36; C, estágio 37; D, estágio 40; E estágio 42; F, estágio 43. Av, arco vertebral; Cc, costela cervical; Cd, costela dorsal; $\mathrm{Cv}$, centro vertebral. Barra $3 \mathrm{~mm}$.

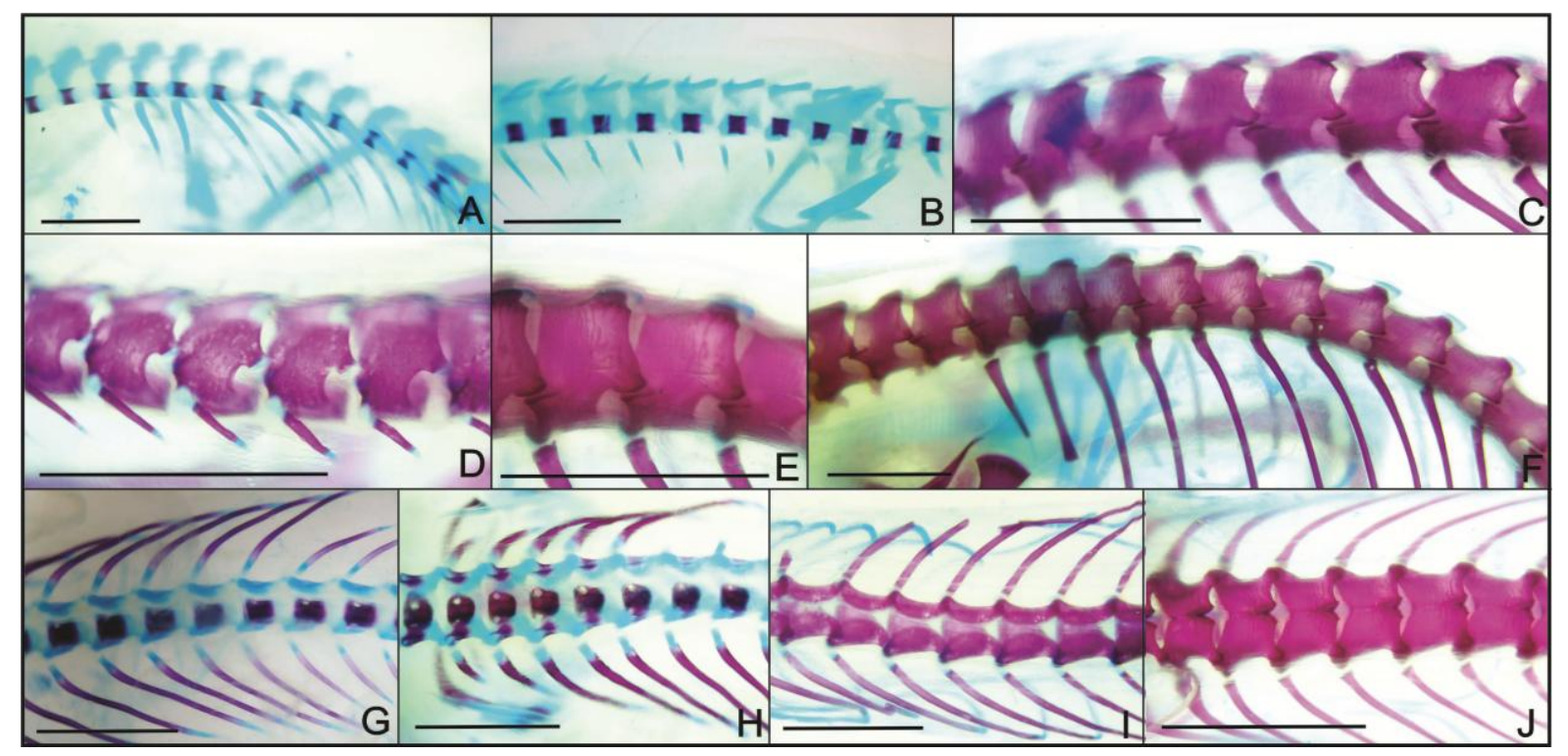

Figura 42: Sequência de ossificação das vértebras dorsais em embriões de I. iguana iguana. A e B estágio 37; C e D, estágio 41; E e F, estágio 43; G e H estágio 39; I, estágio 41; J, estágio 44. Barra $7 \mathrm{~mm}$. 
No estágio 38 as vertebras cervicais ( 2 a 8 ) e as vertebras dorsais exibem centros de ossificação corados com vermelho de alizarina. Em seguida, o esbouço dos processos espinhoso e transverso de cada vértebra se coram por meio da extensão lateral e dorsal do arco vertebral, respectivamente. Ainda durante o estágio 38 as costelas cervicais, dorsais e lombares estão nitidamente marcadas com azul de alcian, o que permite obeservar sua estrutura bem delineada (Figs. 40-42).

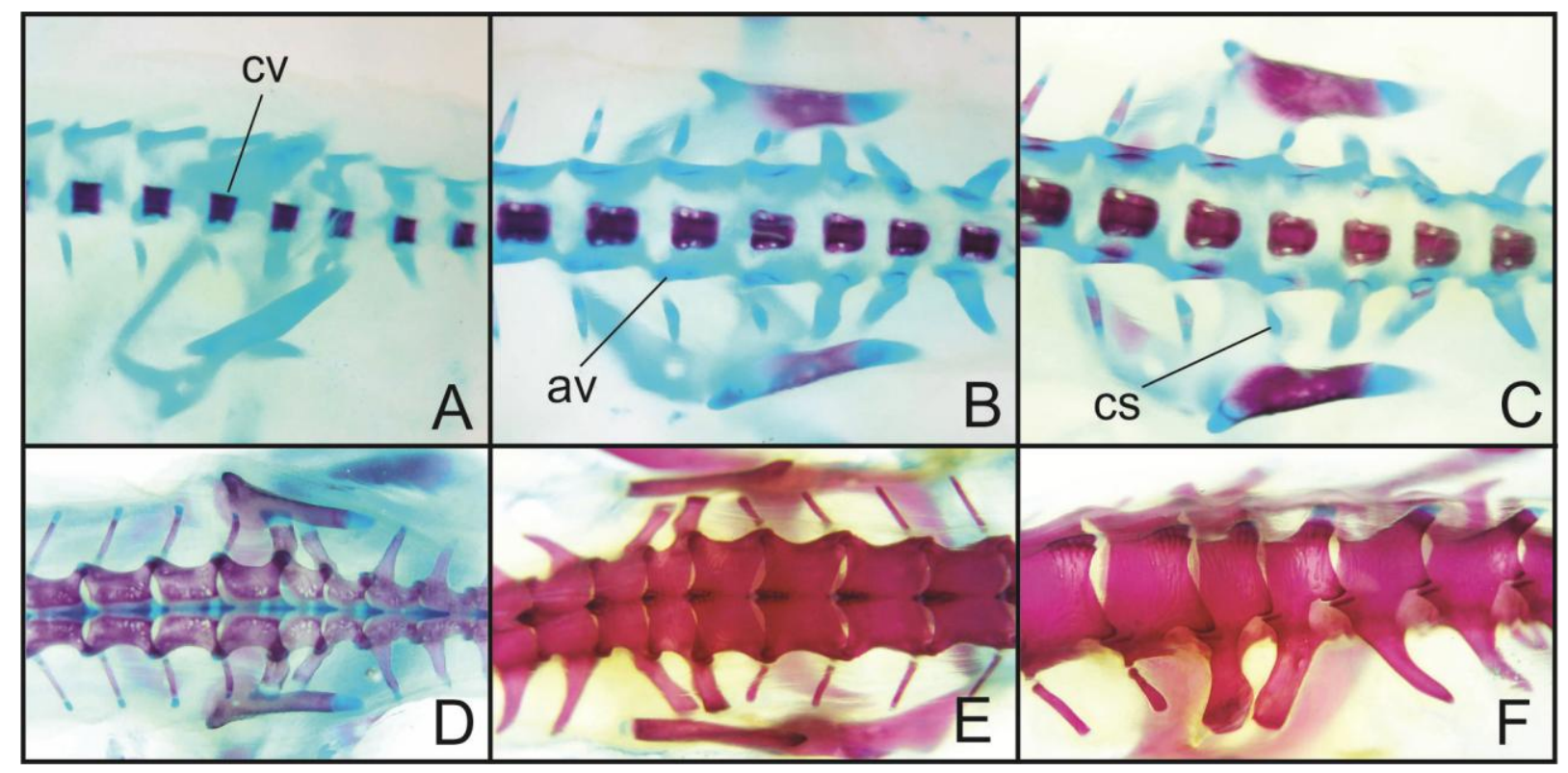

Figura 43: Sequência de ossificação das vértebras sacrais em embriões de I. iguana iguana. A estágio 38; B, estágio 39; C, estágio 40; D, estágio 42; E e F, estágio 44. Ac, arco vertebral; $\mathrm{Cv}$, corpo vertebral; cs, costela sacral.

No estágio 38 ainda podemos observer ainda a formação da estrutura cartilagínea ventral do arco hemal nas vértebras caudais (Fig. 44). O número de condesações cartilagíneas que dará origem as vértebras neste segmento é ainda inconstante entre os embriões avaliados. O mesmo ocorre com a presença do arco hemal. Este se forma no sentido crânio-caudal mas não apresenta um padrão definido nos diferentes embriões.

O processo de ossificação no estágio 39 está bem avançado nos corpos das vértebras craniais em relação aquelas dispostas caudalmente. A retenção de alizarina diminui consideravelmente no sentido caudal, tal como avaliado no desenvolvimento cartilagíneo. Até o final deste estágio, apenas o corpo das vertebras cervicais, dorsais, lombares, sacrais e as caudais proximais se coram com vermelho de alizarina (Figs. 40-44).

No início do estágio 40 as vértebras dorsais, lombares, sacrais e as 5 primeiras vertebras 
caudais exibem centros de ossificação corados no arco vertebral. Existe um processo de ossificação em cada lado do arco vertebral, junto ao corpo da vertebra, que nesta fase possui uma demasiada retenção de alizarina.

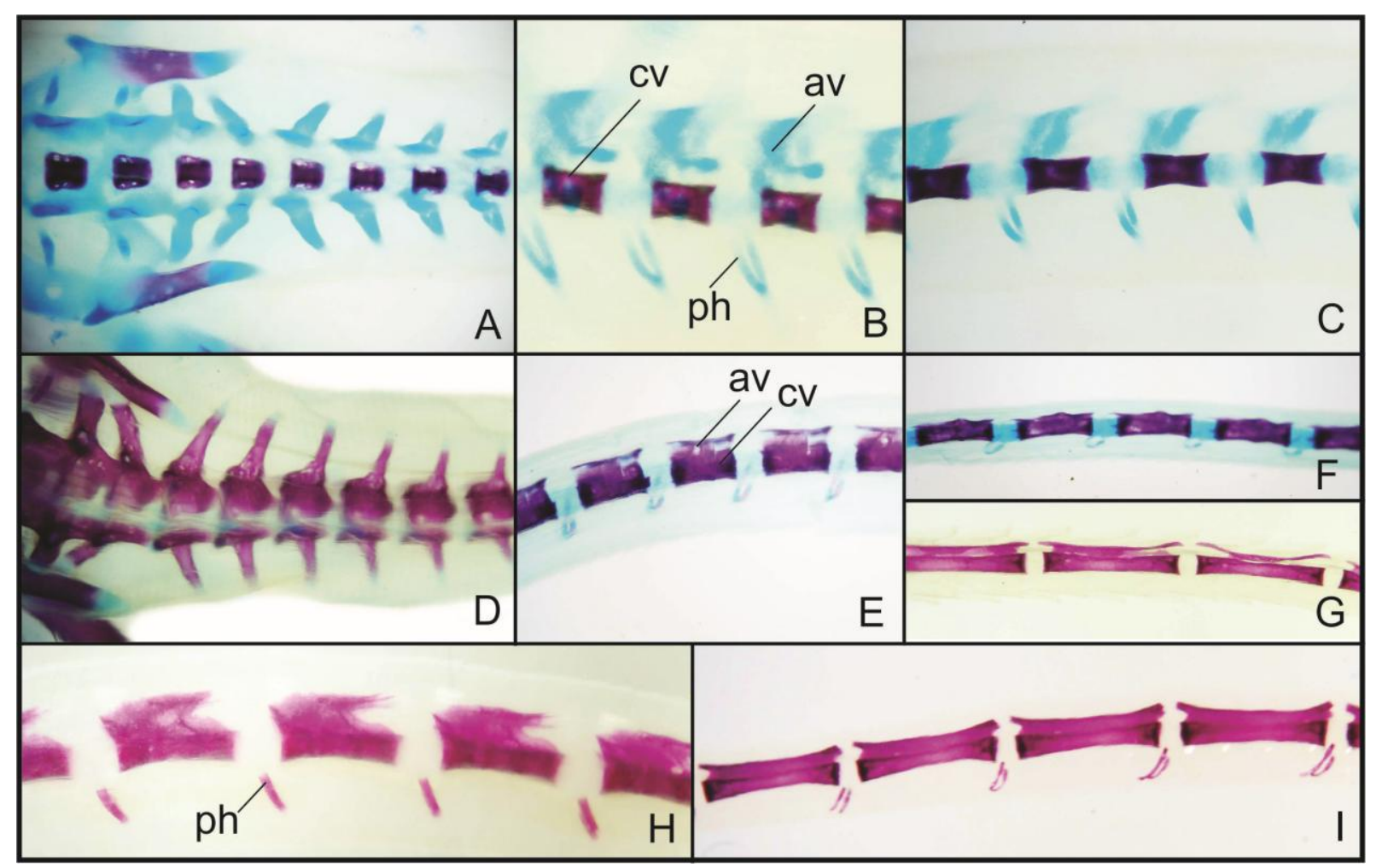

Figura 44: Sequência de ossificação das vértebras caudais em embriões de I. iguana iguana. A-C, estágio 39; D-F e H, estágio 41; G e I, estágio 44. Ac, arco vertebral; Cv, corpo vertebral; ph, processo hemal.

Os processos transversos das vértebras caudais I a III iniciam a ossificação juntamente com todas as costelas cervicais, dorsais e lombares neste estágio. Não é possível determinar a ordem de ossificação destas costelas, outrora, avaliando o limiar visual de retencão do corante, novamente o padrão crânio-caudal é evidente.

A cartilagem esternal bem como ambas as clavículas apresentam-se em processo de ossificação no estágio 39 (Fig. 45). O esbouço da interclavícula em formato de T, tal como no adulto está bem definido neste estágio. A cartilage esternal permanence até o estágio da eclosão marcada com azul de alcian (Fig. 45C). 


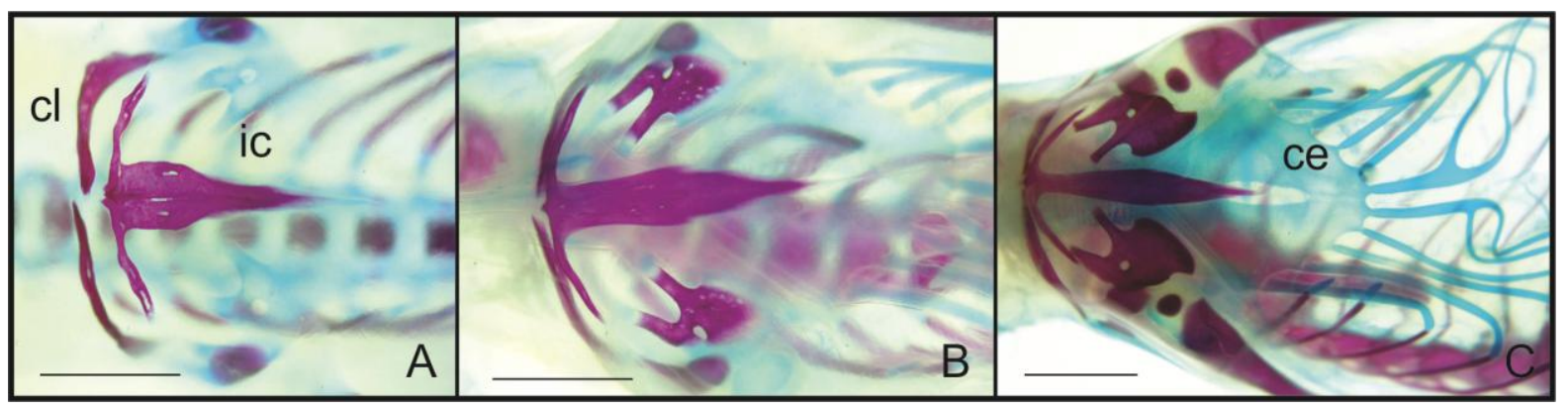

Figura 45: Sequência de ossificação do esqueleto peitoral em embriões de I. iguana iguana. A, estágio 39; B, estágio 41; C, estágio 44. ce, cartilagem esternal; cl, clavícula; ic, interclavícula. Barra $3 \mathrm{~mm}$.

A partir do estágio 40 o desenvolvimento ósseo dos arcos vertebrais continua em sentido crânio-caudal. No estágio 41 os arcos das vértebras cervicais e dorsais estão bem ossificados, mas ainda não estão fundidos na linha mediana, o que ocorre apenas após o início do estágio 42. Os procesos hemais das vertebras caudais estão em avançado processo de ossificação nesta fase, onde pode-se notar a presença de uma quantidade de cartilagem ao longo da linha mediana dorsal, evidenciando que os processos espinhosos ainda permanecem cartilagíneos.

No estágio 43, os arcos e corpos vertebrais, processos espinhosos e transversos de todas as vértebras estão ossificados e a estrutura da coluna vertebral formada.

\section{Condrogênese do Membro Torácico}

Visto tratar-se de uma espécie que apresenta grande desenvolvimento inicial ainda no oviduto, ocorrendo a oviposição no estágio 27 , a formação das primeiras estruturas cartilagíneas dos membros ocorre relativamente cedo (Fig. 39). O broto dos membros está presente no embrião do estágio 28 , embora ainda pouco proeminente, esta estrutura marca a transição para este estágio. As formações condrogênicas ocorrem posteriormente e podem ser acompanhadas por meio da coloração dos espécimes a partir das fases subsequentes.

As condensações cartilagíneas referentes aos ossos da cintura torácica estão completmente distintas no estágio 34. A partir do estágio 35 é possível observar o contorno do molde de cartilagem da escápula e do coracóide (Fig. 38).

No estágio 37 a escápula exibe uma insconpícua área corada em sua parte média que indica o início do processo de ossificação, confirmado pela retenção de corante no estágio 38, ainda sem indícios do processo osteogênico no coracóide. Apenas no estágio 39, também pela 
parte média da cartilagem, o coracóide exibe seu centro de ossificação. Ambos os ossos da cintura torácica estão bem marcados no estágio 40 (Fig. 38F).

Úmero, rádio e ulna exibiram centros de ossificação na parte média da diáfise nos embriões do estágio 38 (Fig. 38E). Em um dos espécimes avaliados, foi possível observar que o úmero apresentou um discreto aumento na retenção de Alizarina, sugerindo o início de sua ossificação antes de rádio e ulna.

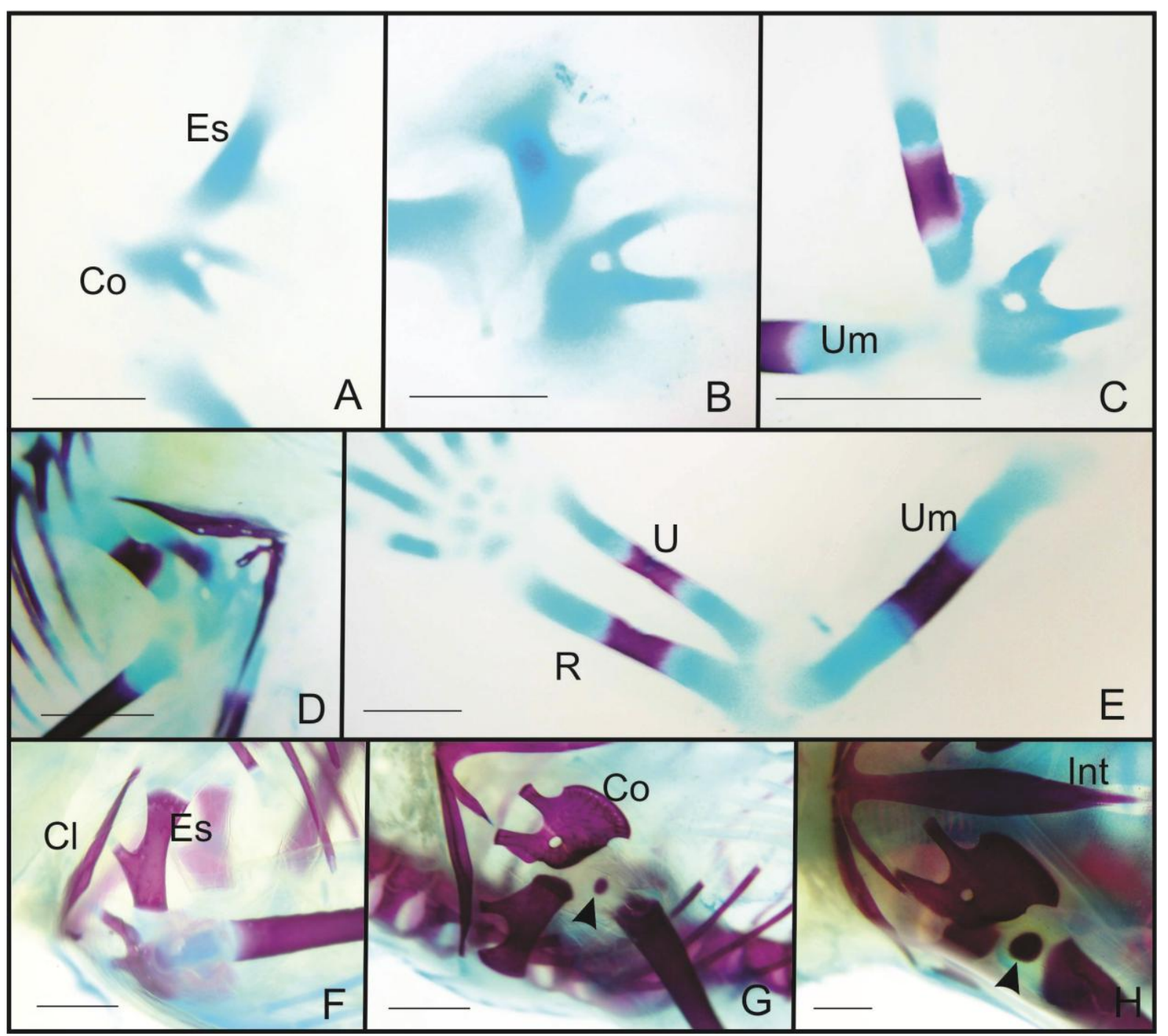

Figura 46: Sequência de formação da cintura e membros torácicos em embriões de I. iguana iguana. A, estágio 35; B, estágio 37; C-E, estágio 38; F, estágio 40, G, estágio 43; H, estágio 44. Cl, clavícula; Co, coracóide; Es, escápula; Int, interclavícula; R, radio,; U, ulna; Um, úmero. Em $\mathrm{G}$ e $\mathrm{H}$ está presente um centro de ossificação secundário independente para a epífise do úmero (cabeça da seta). Barra $4 \mathrm{~mm}$. 
No embrião do estágio 28 existe em seu membro torácico uma extensa área marcada por Azul de Alcian embora esta seja ainda de difícil observação com relação a presença de condensações precisas atribuídas a formação dos elementos cartilagíneos do referido membro. No estágio 29 é possível observar com clareza a formação das primeiras condensações que esboçam o modelo cartilagíneo do zeugopódio e estilopódio dos membros torácicos de $I$. iguana iguana. Tal como descrito para nos demais vertebrados por Shubin e Alberch (1986) o modelo assume forma de Y, sendo o desenvolvimento na direção proximal-distal para o eixo primário e de pós para pré-axial durante a formação do arco digital (Fig. 39). Neste estágio estão presentes as condensações cartilagíneas dos ossos úmero, rádio e ulna.

As primeiras condensações no autopódio ocorrem no estágio 29. Uma segmentação da cartilagem da ulna forma a cartilagem do ulnar do carpo que segmenta-se e origina a cartilagem do distal do carpo IV, que nesta fase é contínua com a alongada cartilagem do metacarpo IV. Esta formação corresponde no eixo primário, o precursor do desenvolvimento do membro dos vertebrados (Fig. 39).

Ainda neste estágio estão presentes as condensações do distal do carpo III do qual se alonga uma condensação referente ao metacarpo III, contínuas em uma placa única com a extremidade proximal dilatada. Da cartilagem do rádio segmenta-se uma pequena porção que origina a cartilagem do radial do carpo.

Nos espécimes avaliados, posicionada adjacente a conspícua cartilagem do radial do carpo está inclusa em uma área que apresenta uma condensação independente, sem conexão direta com as segmentações oriundas do eixo primário ou do rádio (Fig. 39 e 40). A partir da análise das condensações presentes nesta região, diversos autores tem discutido sobre a presença de elementos centrais e intermédio do carpo em lagartos. Nossos dados oferecem a possibilidade de discutir sobre a formação desses elementos em I. iguana iguana a partir da observação da não diferenciação completa do distal do carpo I e metacarpo I e da presença de dois elementos formados a partir desta zona de diferenciação aparte do arco digital (Fig. 40).

Diversas outras estruturas são visualizadas durante o estágio 31. A extremidade distal do membro torácico está definida pela presença do arcabouço dos dígitos que, com oito dias após a oviposição apresenta base cartilagínea, embora o I e o V sejam ainda inconspícuos em coloração de Azul de Alcian. A cartilagem do distal do carpo IV é evidente e dos distais III e II diferenciadas do alongado esbouço cartilagíneo do respectivo metacarpo (Fig. 39). 


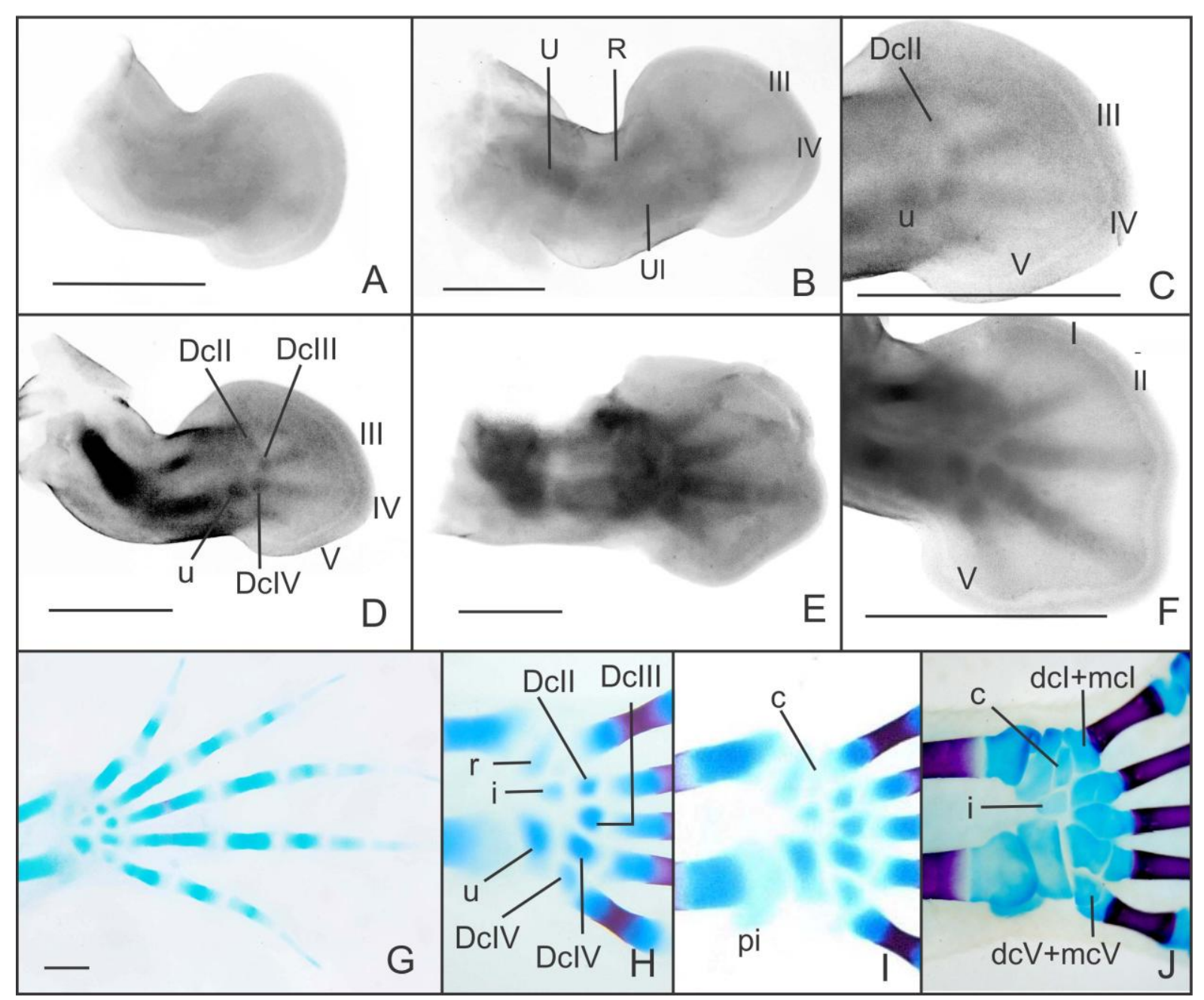

Figura 47: Sequência de formação cartilagínea dos membros torácicos em embriões de $I$. iguana iguana. No estágio 28 (A) é difícil a identificação de estruturas, embora exista indícios do início do processo de condensação condrogênica, tornando evidente a presença do eixo primário pela estrutura visível do dígito IV. Estágio 29 (B) com clara presença do eixo primário, seguindo o desenvolvimento pela formação do arco digital (C) e avanço do processo ontogênico nos estágios 31 (D) e 32 (E e F). No estágio 32 o embrião corado apresenta 8 condensações (G). O pisiforme é um elemento conspícuo a partir do estágio 33 (I). J apresenta a morfologia completa do carpo cartilagíneo de I. iguana iguana no estágio 38. U, úmero; R, rádio; Ul, ulna; I, II, III, IV, V, dígitos; DcIII, distal do carpo III; DcIV, distal do carpo IV; DcII, distal do carpo II, DcV; distal do carpo V; c, central; i, intermédio; mc, metacarpo; pi, pisiforme; u, ulnar; r, radial. Clareamento com KOH e coloração com Alcian blue. Barra $1 \mathrm{~mm}$. 


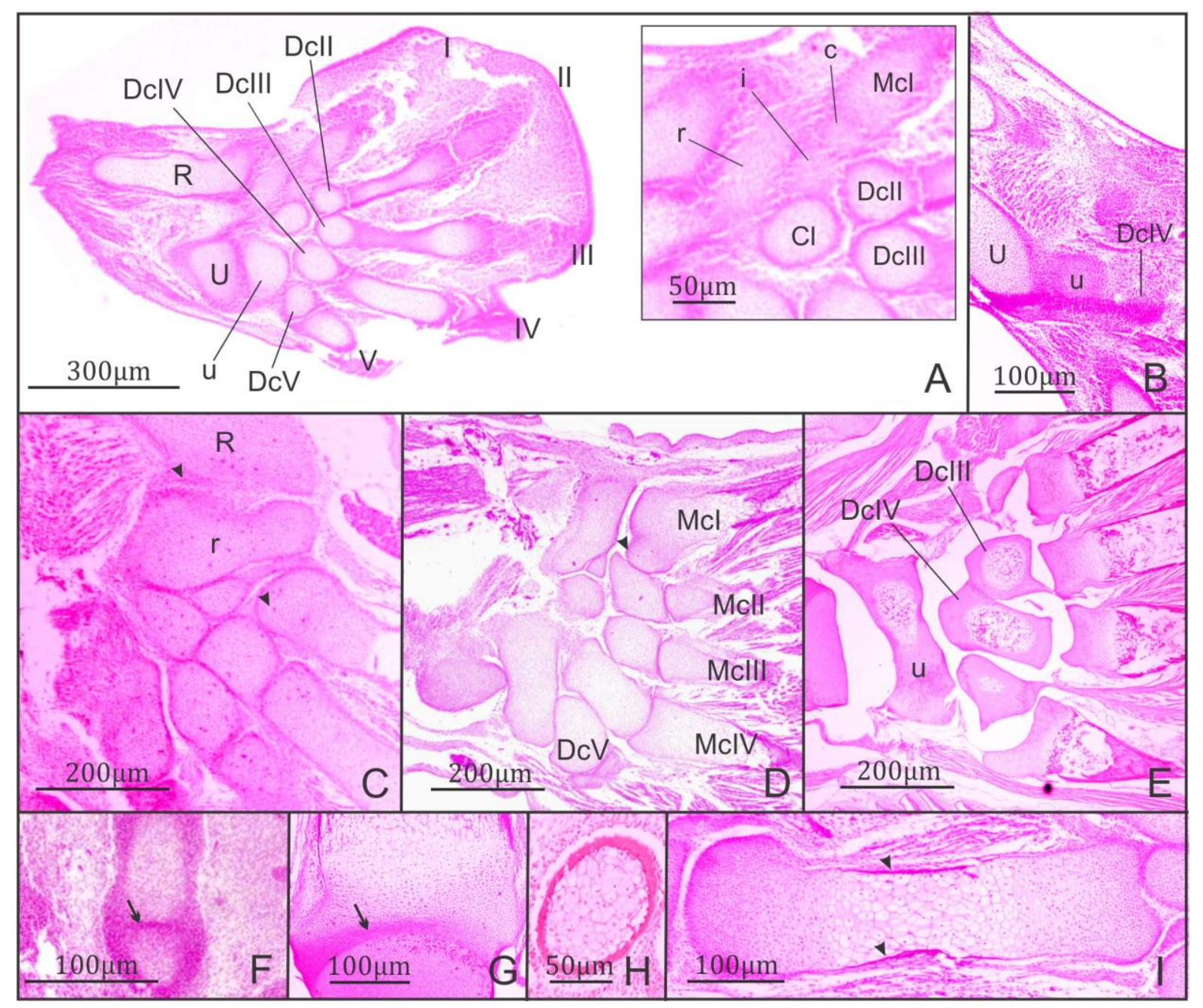

Figura 48: Cortes da sequência de formação dos elementos do autopodio dos membros torácicos em embriões de I. iguana iguana. Vista palmar panorâmica do estágio 35 (A). Estão presentes todos os dígitos. Os elementos distais II a V são conspícuos na base do respectivo metacarpo. No detalhe a direita é possível visualizar o primórdio do distal do carpo I na base do metacarpo I, embora durante a ontogenia o referido elemento não se desenvolva por completo (estágio 38 [D] - cabeça da seta). Radial e ulnar estão evidenciados na extremidade distal do radio e ulna, respectivamente. O elemento intermédio apresenta-se conspícuo e, no detalhe, é possível reconhecer a forma inconspícua do central surgindo como um elemento independente. No estágio 34 (B) a formação do eixo primário está adiantada, sendo possível a definição dos elementos ulnar e distal do carpo IV. Autopódio no estágio 35 (C) evidenciando a relação entre o radio e o radial (cabeça da seta). Estágio 38 (D), sendo possível a visualização de quatro elementos distais e seus respectivos metacarpos. Nesta imagem o metacarpo I exibe uma área proximal correspondente ao distal do carpo I (cabeça da seta), fundido em estrutura única visto que este não segmenta-se da cartilagem do metacarpo. Em E, durante o estágio 42, alguns elementos do carpo (DcII, DcIII, DcIV e u) apresentam 
hipertrofia da cartilagem, evidenciando o início do processo de ossificação. Segmentação (seta) da cartilagem da falange 1 a partir do metacarpo no estágio 34 (F) e 35 (G). Corte transversal (H) e longitudinal (I) de um metacarpo no estágio 37. O anel pericondral exibe sinais conspícuos de ossificação, restritos a porção média do elemento (cabeça da seta [I]). A porção interna apresenta uma grande quantidade de cartilagem hipertrófica. $\mathrm{R}$, rádio; $\mathrm{U}$, ulna; I, II, III, IV e V, dígitos; DcI, DcII, DcIII, DcIV e DcV, distais do carpo, u, ulnar; r, radial; i, intermédio; c, central. Coloração H.E.

Quatro distais do carpo são identificados no estágio 33 (Figs. 39 e 40). Alguns ainda apresentam conectividade com a porção proximal da cartilagem do respectivo metacarpo. A cartilagem do metacarpo I apresenta uma estrangulação proximal que sugere a formação tardia do distal do carpo I. Neste estágio o intermédio do carpo está presente, contatando medialmente o radial (Fig. 40). Ele não se segmenta de nenhum outro elemento, sua condensação ocorre de maneira independente, tal como observado para o central carpo.

No estágio 34 a maior parte da estrutura cartilagínea do membro torácico está definida. Os distais do carpo de II a V estão distintos e segmentados dos respectivos metacarpos (Fig. 39 e 41). Radial e ulnar completamente independentes do radio e ulna, respectivamente. A cartilagem do intermédio ocupa a porção média do autopodio, entre o radial e o ulnar, estando bem evidente. Discreta, porém presente, a cartilagem do central está localizada entre o distal do carpo II e o radial, distal e proximal a estes, respectivamente. O distal do carpo I não se torna um elemento completamente segmentado do metacarpo I, permanecendo fundido (Fig. 40). A extremidade proximal deste metacarpo torna-se então pronunciada e alcança uma porção mais proximal em relação aos demais.

A formação das falanges ocorre sistematicamente por meio da formação de uma pequena área que sugere uma estrangulação da barra cartilagínea e posterior segmentação (Fig. 40). Tal manobra ocorre no sentido próximo-distal, primeiro nos dígitos IV, III e II, a partir do estágio 34 e, posteriormente no dígitos I e IV no estágio 36 . No estágio 37 as falanges ungueais segmentam-se e o estágio 38 a fórmula falângica é 2:3:4:5:3 (Fig. 41).

Não foi possível observar nos espécimes avaliados a formação pormenorizada do dígito V. Embora seja quase consenso entre os pesquisadores, ainda existem poucos dados que comprovam em lagartos a formação do referido dígito a partir de uma nova condensação fora do arco digital. Para I. iguana iguana acreditamos que tal informação corrobora os achados de outros visto que, no final do estágio 31 o dedo V pode ser observado em estágio avançado de desenvolvimento antes mesmo da segmentação do dedo I pelo carco digital. Em 
avaliação histológica não foi averiguado qualquer indício que nos leve a concluir que exista conectividade entre este dedo e o arco digital.

\section{Ossificação do membro torácico}

A ossificação no membro torácico tem inicio durante o final do processo de condrogênese, no estágio 36, com a fixação de corante na porção média do úmero, rádio e ulna. Posteriomente, já no estágio seguinte, o metacarpo III exibe discreta retenção de alizarina nas bordas da diáfise (Fig. 49).

Durante o estágio 38 ocorre um conspícuo acréscimo no processo de ossificação, caracterizando duas fases de desenvolvimento, uma inicial (38-) e outra final (38+). Primeiramente os metacarpos II, III e IV exibem uma conspícua coloração com vermelho de alizarina e, posteriormente, as falanges 1 dos dígitos I, II e III e a falange 2 do dígito III. No final deste estágio os metacarpos I e V iniciam sua ossificação seguidos pelas demais falanges, exceto as ungueais (Fig. 49).

Além da retenção de vermelho de alizarina, o material foi avaliado histologicamente, permitindo confirmar que, no decorrer do estágio 38, todos os metacarpos e as referidas falanges apresentam características celulares que confirmam o processo inicial de ossificação (Fig. 48I). Tratam-se de ossos longos típicos que apresentam, no estágio anterior (37), hipertrofia das células de cartilagem da porção média da diáfise. A membrana periostal exibe, no estágio 38, sinais evidentes do início da ossificação como espessamento, presença de células osteogenitoras.

No decorrer do estágio 40 as falanges ungueais iniciam sua ossificação, primeiro os elementos dos dígitos I, II e III e no final deste estágio as dos dígitos IV e V (Fig. 49E). O arcabouço ósseo dos dígitos está bem marcado e em plena atividade osteogênica no estágio 41. Neste mesmo estágio os condrócitos mostram uma intensa atividade hipertrófica na porção interna da cartilagem do distal do carpo IV, radial e distal do carpo III, mas ainda sem marcação por alizarina devido a ausência de deposição de minerais (Fig. 48E). 


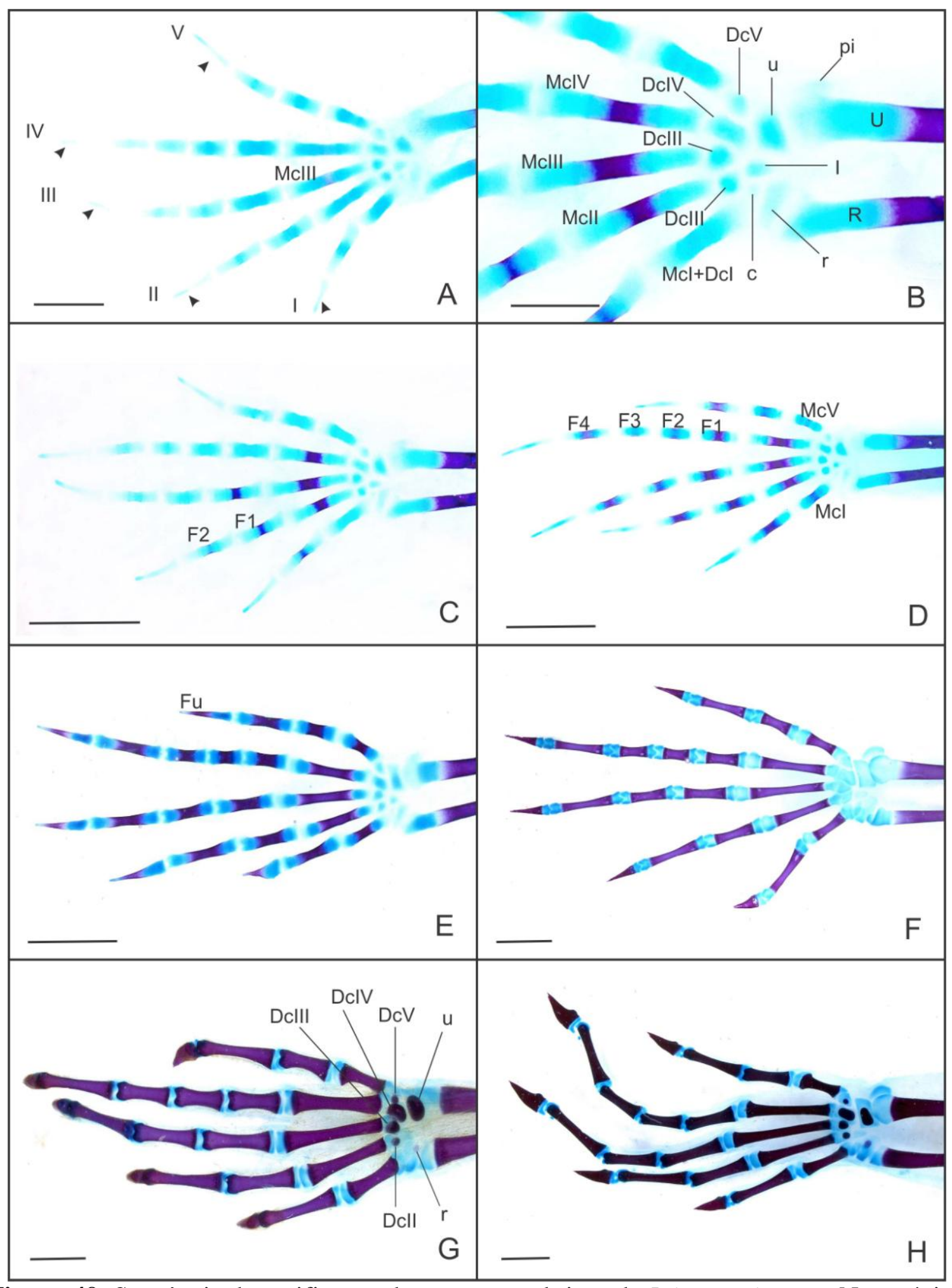

Figura 49: Sequência de ossificação da mão em embriões de I. iguana iguana. No estágio 33 (A) todos os elementos cartilagíneos estão formados, sendo possível observar o início do processo de ossificação no metacarpo III e de forma inconspícua no metacarpo IV. As falanges ungueais apresentam condensação do esbouço cartilagíneo (cabeça da seta). No 
início do estágio 38 (B) os metacarpos II, III e IV estão em processo de ossificação inicial e algumas falanges 1. A ossificação das falanges ocorre no decorrer do estágio 38 (C) e 39 (D). As falanges ungueais apresentam ossificação no estágio 40 (E). Todos os elementos dos dígitos iniciaram sua ossificação até o estágio 42 (F). Início da ossificação do autopódio, estágio $43(\mathrm{G})$ e aspecto no final do período de incubação, no estágio $44(\mathrm{H})$. R, rádio; U, ulna; I, II, III, IV e V, dígitos; DcII, DcIII, DcIV e DcV, distal do carpo; u, ulnar, r, radial; c, central; i, intermédio; pi, pisiforme; Mc, metacarpos; F, falanges; Fu, falange ungueal. Clareamento com KOH e coloração com Alizarina red S e Alcian blue. Barra $1 \mathrm{~mm}$.

Somente no estágio 43 os elementos do autopódio iniciam sua ossificação. Ulnar e distal do carpo IV apresentam pela primeira vez retenção de corante, embora no estágio anterior tivessem apresentado indícios do processo de ossificação em nível histológico. Os próximos elementos do carpo a iniciar a ossificação são o distal III e distal V, ambos durante o início do estágio 44, e no final deste período o radial apresenta uma discreta retenção de corante. Pisiforme, central, intermédio e distal do carpo II não exibem qualquer atividade relativa a ossificação durante o período de incubação (Fig. 49G e H).

\section{Condrogênese do membro pelvino}

Aos cinco dias a partir da oviposição o membro pelvino, que apresenta uma característica externa pronunciada, inicia a formação de seu arcabouço cartilagíneo. Condensações de células mesenquimais instituem placas alongadas e bem pronunciadas de cartilagem que, no estágio 31, são visíveis pela coloração com azul de Alcian na forma clássica de Y, representando o fêmur, tíbia e fíbula (Fig. 50).

No estágio 32 os principais elementos constituintes do eixo primário estão presentes no membro pelvino de I. iguana. Inicialmente são visíveis a cartilagem do fibular, distal do tarso IV e três bastões cartilagíneos correspondentes a estrutura dos artelhos IV, III e II, ainda

sem muita diferenciação. É visível, visto maior contraste do corante, que a extremidade proximal destes últimos dois elementos é mais densa. O fibular pode ser identificado a partir de sua projeção na extremidade distal da cartilagem da fíbula, estando o distal do carpo IV imediatamente distal a ele (Fig. 50). 


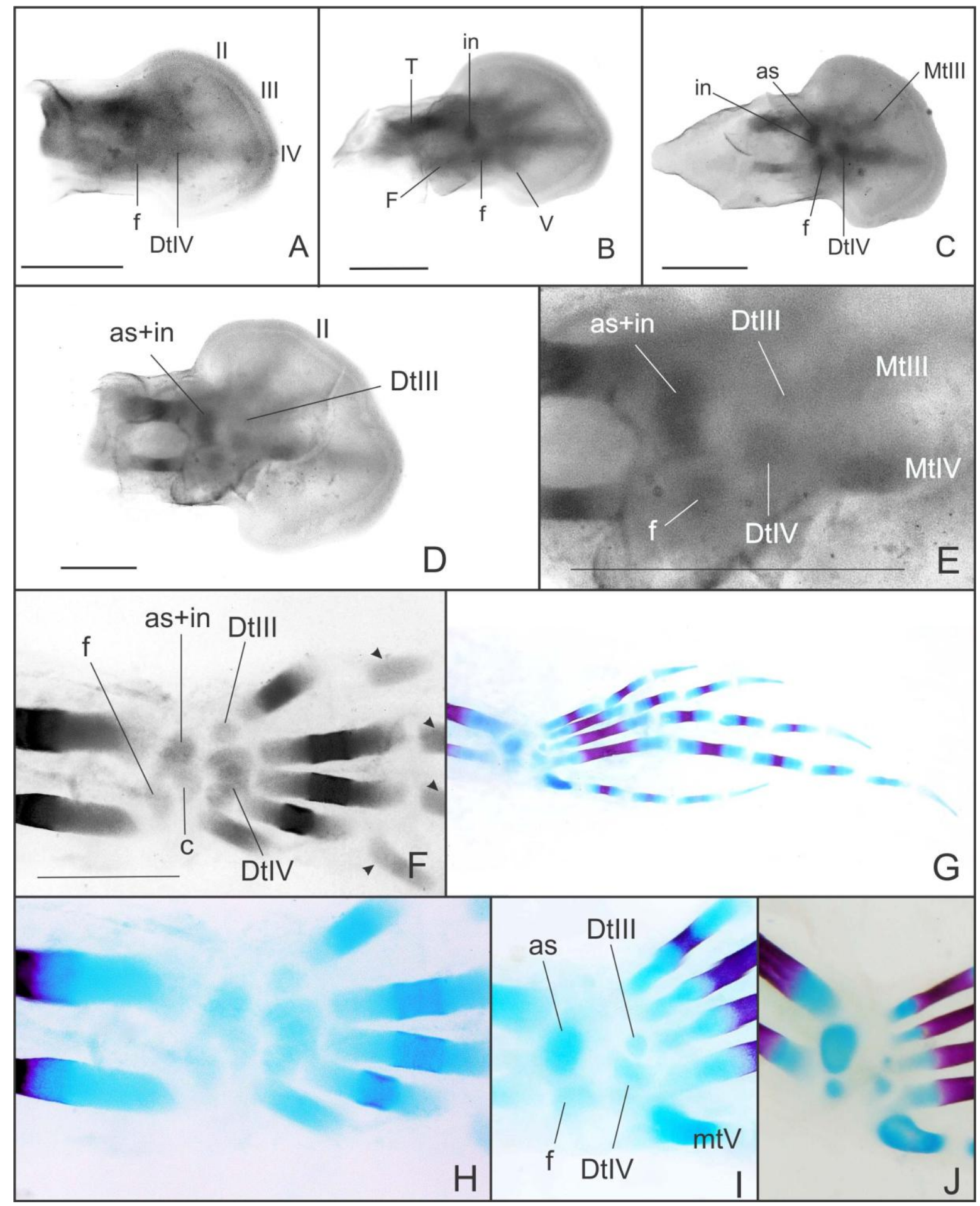

Figura 50: Sequência de formação cartilagínea dos membros pelvinos em embriões de $I$. iguana iguana. No estágio 28 (A) é possível visualizar o processo de condensação condrogênica avançado, apresentando o primórdio dos artelhos IV, III e II. Nos estágios 29 (B) e 30 (C) as presenças do eixo primário e do arco digital marcam o avanço do processo ontogênico. No estágio 31 ( $\mathrm{D}$ e detalhe E) a placa digital está bem desenvolvida. Condensações no autopódio definem a formação de alguns elementos como os distais III e IV, fibular ainda individualizado e a formação do astragalus pela fusão com o elemento 
intermédio (E). No estágio 39 (F) é possível observar que não ocorre a separação dos distais I, II e $\mathrm{V}$ e as falanges segmentaram da cartilagem do metatarso (cabeça da seta). G (detalhe I) apresenta o arcabouço cartilagíneo do pé durante o início do processo de ossificação no estágio 40. H, estágio 38; J. Estágio 41. as, astragalus; F, fíbula; T, tíbia; IV, III e II, artelhos; DtIV, distal do tarso IV; DtIII, distal do tarso III; f, fibular; in, intermédio; Mt, metatarso. Clareamento com KOH e coloração com Alcian blue. Barra $1 \mathrm{~mm}$.

Durante o período final deste estágio o distal do tarso IV torna-se evidente na porção proximal do respectivo artelho, assim como o distal do tarso III (Fig. 50). Os demais primórdios (II e V) não se segmentam do bastão cartilagíneo do metatarso. Uma extensa área na porção central do autopódio, entre as extremidades distais da tíbia e fíbula se destaca por apresentar forte retenção de azul de Alcian, a condensação primária do intermédio (Fig. 50B).

O arcabouço do membro pelvino está definido no estágio 33. O autopódio possui duas cartilagens proximais destacadas, fibular e intermédio, e outras duas distais, distal do tarso III e distal do tarso IV. As cartilagens precursoras do artelhos de I a V estão presentes e, na base dos metatarsos I, II e V, está presente uma pequena dilatação que sugere a formação de elementos distais que não se segmentaram durante a formação do arco digital (Fig. 51B).

Distal do tarso III e IV são as únicas estruturas da fileira distal que se formam completamente (Figs. 50 e 51). A avaliação histológica permite confirmar que os elementos distais I, II e V de fato não se desenvolvem. Durante a ontogenia o distal do tarso IV torna-se robusto e ocupa grande parte na região distal do autopódio. Diretamente relacionado com o metatarso III e localizado entre a extremidade proximal deste e do metatarso II, o distal do tarso III é pequeno, esférico desloca-se lateralmente devido o desenvolvimento do distal do tarso IV.

Em continuidade ao desenvolvimento, a extremidade distal das cartilagens dos metatarsos sofrem sucessivas segmentações para formar as falanges. Tais eventos ocorrem a partir do início do estágio 33, nos artelhos IV e III, sendo acompanhados pelos demais até o estágio 35 quanto a fórmula falângica é igual aos indivíduos adultos, 2:3:5:4:4 (Fig. 52). 


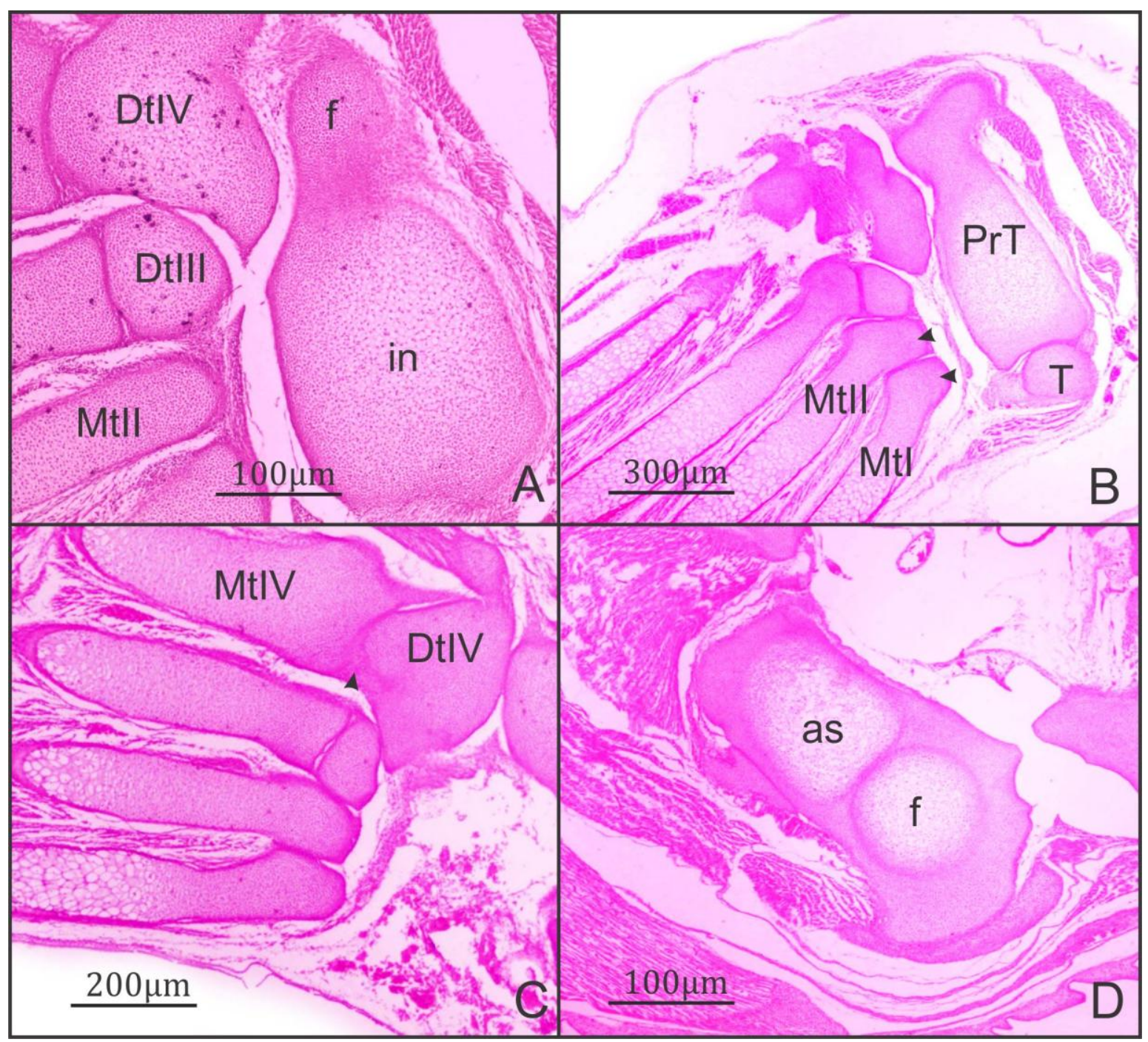

Figura 51: Autopodio dos membros pelvinos em embriões de I. iguana iguana. Cortes em diferentes períodos de desenvolvimento durante o estágio 38 (A, B e C). Os únicos elementos distais presentes estão destacados, sendo o DtIII e DtIV, contatando seus respectivos metatarsos. Em A, o nível dorsal do corte permite a visualização de duas estruturas distintas para o fibular e o intermédio (formando o astragalus), estando estes em B como um grande e único elemento denominado proximal do tarso. Ainda podemos notar a não segmentação dos elementos distais I e II a partir da extremidade proximal da cartilagem do metatarso (cabeça da seta [B]). A relação entre o metatarso IV e o DtIV (cabeça da seta) é visualizada em C. Estas estruturas estão diferenciadas, porém uma extensa área de tecido compartilhado é conspícua. No estágio 43 (D) a estrutura da matriz cartilagínea se altera, sendo possível notar o primórdio de dois centros de ossificação distintos para o elemento proximal do tarso, um para o fibular e outro para o astragalus. as, astragalus; DtIII, DtIV, distal do tarso; f, fibular; in, intermédio; T, tíbia; MtI, MtII, MtIV, metatarso; Prt, proximal do tarso. Coloração H.E. 
No decorrer da ontogenia, as cartilagens proximais do autopódio desenvolvem continuamente e se contatam, formando um elemento único, grande e robusto. Esta tendência é observada a partir do estágio 38 quando existe um deslocamento (ou crescimento), aparentemente do intermédio, da posição anterior em direção ao fibular (Fig. 50E e 51B). A anatomia microscópica indica um acréscimo no tamanho do intermédio que expande sua porção cartilagínea na direção lateral e contata o fibular. Até o final deste estágio estes dois elementos estão fundidos, sendo possível observar uma discreta separação destas estruturas, histologicamente (Fig. 51D).

\section{Ossificação do membro pelvino}

O processo de ossificação no membro pelvino de I. iguana inicia-se no final da terceira semana após a oviposição, concomitante com o final do processo de condrogênese dos membros. Fêmur, tíbia e fíbula são os primeiros elementos a iniciar sua ossificação, ainda no início do estágio 36. Embora discreta a retenção de corante marca a porção média da diáfise destes elementos, evidenciando um nítido anel periosteal. Em corte transversal, no final deste estágio é possível observar uma espessa camada circular de tecido calcificado com a presença de algumas células ósseas. O espaço interno é preenchido completamente por muitas células cartilagíneas hipertróficas.

Ainda neste estágio o metatarso IV exibe uma inconspícua retenção de vermelho de alizarina porém, somente no estágio 37 é possível visualizar com mais nitidez. Acompanhando este, os metatarsos II e III também apresentam-se em processo inicial de ossificação neste período, outrora, em uma fase menos pronunciada (Fig. 52).

No estágio 38 o metatarso I exibe uma discreta e inconspícua retenção de corante. $\mathrm{O}$ metatarso $\mathrm{V}$ é o último destes elementos a se ossificar. Nos embriões avaliados ele apresentou algumas variações na cronologia. Em dois espécimes ele estava corado no final do estágio 38. No estágio 39 ele está presente somente como estrutura cartilagínea, voltando no estágio 40 a apresentar centro de ossificação corado, sendo de fato o último metatarso a iniciar sua ossificação (Fig. 52). 


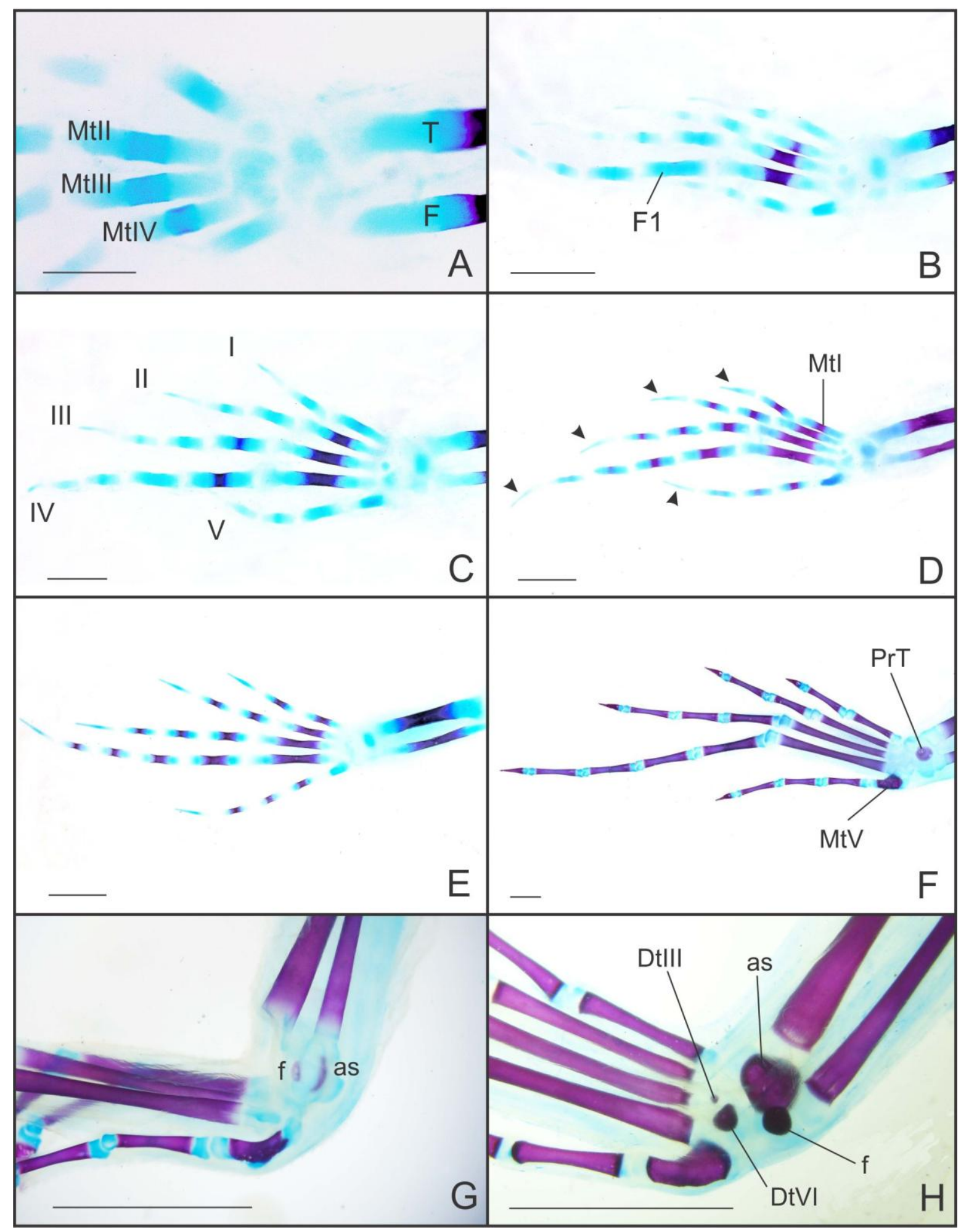

Figura 52: Sequência de ossificação do pé em embriões de I. iguana iguana. No estágio 38 (A) todos os elementos cartilagíneos estão formados, sendo possível observar o início do processo de ossificação nos metatarsos II, III e IV. Durante o estágio 38 (B) e 39 (C) a ossificação nas falanges tem inicia. As falanges ungueais (cabeça da seta) não apresentam ossificação no estágio 39 (D). O metacarpo V evidencia uma inconspícua retenção de corante 
no estágio 40 (E). O início da ossificação do autopodio ocorre no estágio 43 (F e G) onde pode ser observado a presença de dois centros de ossificação distintos para este elemento. No estágio 44 (H) o DtVI e o DtIII apresentam centros de ossificação marcados. as, astragalus; T, tíbia; F, fíbula; I, II, III, IV e V, artelhos; Mt, metatarso; F1, falanges; f, fibular; Prt, proximal do tarso. Clareamento com KOH e coloração com Alizarina red S e Alcian blue. Barra $1 \mathrm{~mm}$.

As falanges não exibem uma sequência padrão durante a ossificação, que ocorre durante o estágio 38 para grande parte das estruturas. Os primeiros elementos a apresentar processo osteogênico no início do referido estágio são as falanges 1 dos artelhos IV, II e III e no decorrer do período nos artelhos V e I, nesta ordem. No final do estágio 38 as falanges 2 e 3 dos artelhos III e IV e a falange 2 do artelho V. Na transição para o estágio 39 a falange 3 do artelho V e a falange 4 do artelho IV estão em fase inicial de ossificação.

Somente no estágio 40 as falanges ungueais iniciam sua ossificação. As estruturas dos artelhos I e V, seguidas pelas demais. Ao final deste estágio todos os elementos ósseos dos artelhos exibem um esbouço bem marcado (Fig. 52).

Ao final do período de condrogênese são formados três elementos cartilagíneos, dos quais apenas um, o elemento proximal, inicia sua ossificação durante o período embrionário. No decorrer do estágio 41 é possível averiguar histologicamente a alteração da estrutura cartilagínea do elemento distal do tarso IV e do proximal do tarso (Figs. 51D e 52F-H). Os condrócitos tornam-se hipertrofiados na porção central do distal do tarso IV e em duas porções no proximal do tarso. No início do estágio 42 os centros de ossificação do elemento proximal do tarso são conspícuos e distintos. Trata-se de duas áreas independentes, uma para o intermédio e outra para o fibular. No decorrer deste estágio estes dois centros de ossificação podem ser visualizados pela coloração com vermelho de alizarina. $O$ processo de osteogênese no distal do tarso IV e distal do tarso III são observados pela retenção de corante no final do período de incubação, no estágio 44 (Fig. 52H).

A pelve inicia sua ossificação antes do cíngulo torácico. No estágio 37 é evidente a retenção de corante pela parte média da cartilagem do ilíaco e no estágio 38 o púbis apresenta um discreto centro de ossificação (Fig. 53). O ísquio inicia sua ossificação no estágio seguinte, estando os três elementos bem ossificados no estágio 42, onde é possível observar centros de ossificação secundários nas epífises do fêmur e tíbia (Fig. 53H, I). 


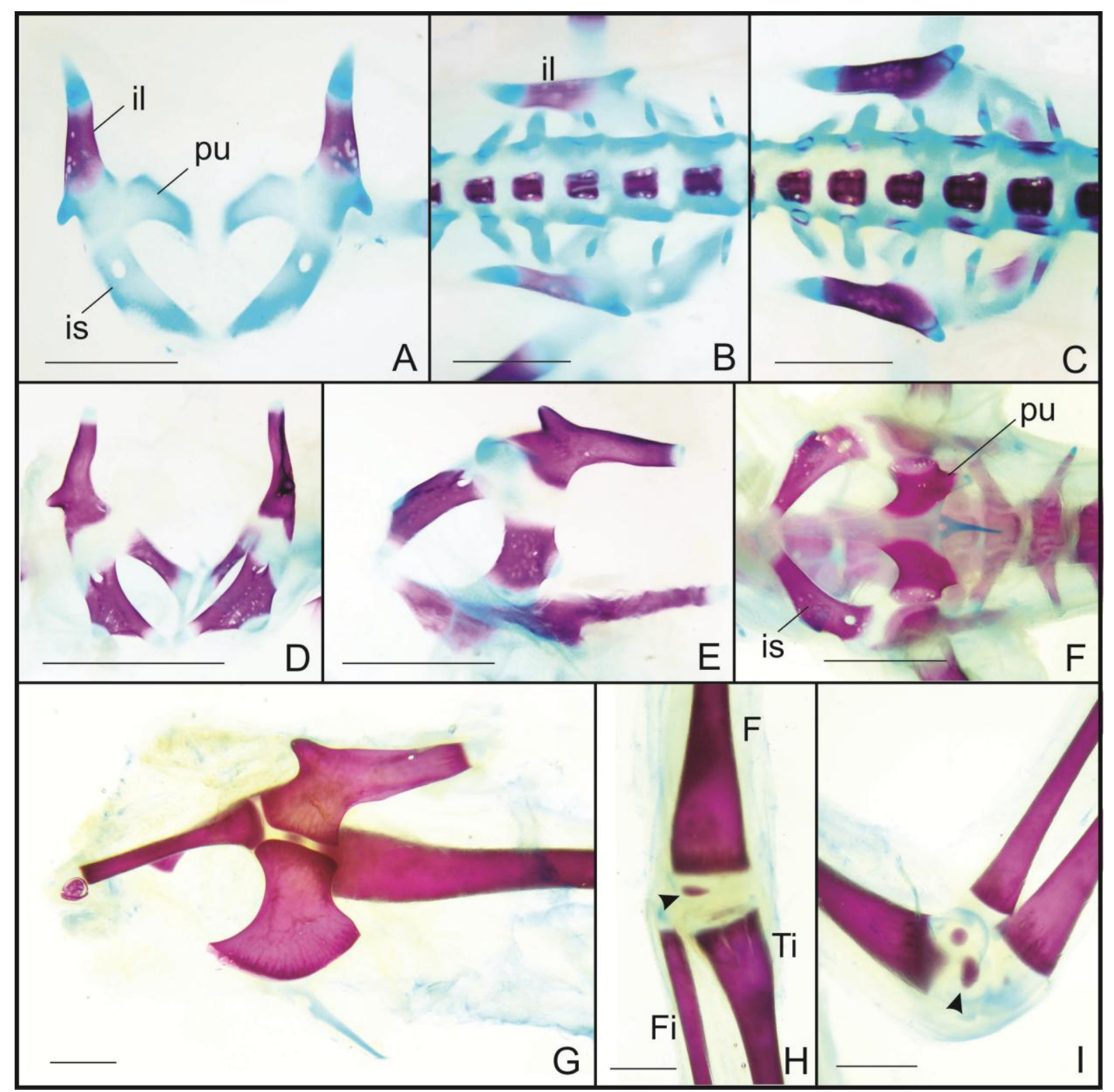

Figura 53: Sequência de ossificação do cíngulo e membro pelvino em embriões de I. iguana iguana. A e B, estágio 38. C, estágio 39. D-F, estágio 40. G e H, estágio 42. I, estágio 43 (cabeça da seta indicando o processo de ossificação secundário na epífise do osso). F, fêmur; Ti, tíbia; Fi, fíbula; il, ilíaco; is, ísquio; pu, púbis. Barra $2 \mathrm{~mm}$.

Os ossos dos membros pelvinos são observados com retenção de corante silmultaneamente no estágio 38, tal como ocorre com os ossos do membro torácico. No embrião do estágio 38, neste segmento, estavam presentes os centros de ossificação do ilíaco, fêmur, tíbia e fíbula, embora estes dois últimos visualmente menos destacados pelo corante. 


\section{DISCUSSÃO}

\subsection{Estágios embrionários}

A sequência de eventos morfológicos adotados para o estabelecimento dos estágios de desenvolvimento de I. iguana iguana é similar à investigações previamente estabelecidas para outros lagartos, embora seja destacadas algumas diferenças (Sanger et al., 2008; Noro et al., 2009; Wise et al., 2009). Segundo Wise et al. (2009) estas descrições podem ser amplamente aplicadas a estas espécies, embora metodologias e critérios de utilizados sejam díspares. De fato, tais caracteres sirvam para conduzir a uma ideia de desenvolvimento, uma progressão unidirecional que condiciona à interpretação de um estágio inicial a uma forma final. Com a utilização das principais características relacionadas na literatura, a tabela normal de desenvolvimento para I. iguana iguana apresentou-se similar àquelas dos demais répteis.

Comparar as tabelas de desenvolvimento entre os diferentes lagartos pode ser difícil devido à incompatibilidade de critérios utilizados por alguns autores. A tabela de desenvolvimento produzida para I. iguana iguana corroborou com aquelas existentes para outras espécies. Pequenas variações estiveram presentes, todavia existiu uma coerência forte entre os animais relatados, mesmo diante a existência de algumas variações metodológicas e, consequentemente da forma em que os resultados de cada investigação foram relatados. Segundo Wise et al. (2009), as descrições dos estágios embrionários mesmo sob condições controladas podem não apresentar uma congruência morfológica das estruturas externas idêntica, embora estejam cronologicamente em situação similar ou até mesmo idêntica.

Particularmente para I. iguana iguana, após o evento da oviposição os embriões apresentavam estágio relativamente avançado de desenvolvimento, haja vista uma característica particular desta, e de outras espécies do grupo, que apresentam desenvolvimento inicial no útero e ovidutos (Shine, 1983; De Marco, 1992; Blackburn, 1995; Mathies e Andrews, 1999). Algumas espécies de lagartos retêm seus ovos até o estágio 26, outras poucas passam do estágio 33 (Defaure e Hubert, 1961), e a eclosão ocorre a partir do estágio 40. De fato é fácil compilar alguns dados acerca dos estágios de eclosão, muito embora determinados autores prefiram adotar uma forma singular em suas tabelas de desenvolvimento, o que pode dificultar algumas discussões cronológicas. Todavia, Anolis sangrei, Lacerta agilis exigua e Urosaurus ornatus eclodem no estágio 40 (Defaure e Hubert, 1961; Mathies e Andrews, 1999; Sanger et al., 2008), Eublepharis macularius (Wise et al., 2009), Calotes versicolor (Muthukkaruppan et al., 1970), Podorcis muralis e Podorcis viridis 
(Dhovailly e Saxod, 1974) encerram o período de incubação no estágio 42. Perfazendo um período maior para incubação, Chamaleo lateralis (Blanc, 1974) e I. iguana iguana eclodem no estágio 44, enquanto Gallus gallus domesticus (Hamburger e Hamilton, 1951) apresenta 49 estágios.

Palmer et al. (1993) sugeriram que o tempo estimado para a oviposição é a completa formação da casca. Ele ainda exemplificou que em Sceloporus woodi a casca esta completamente formada entre os dias 8-10 da fertilização, mas a deposição de cálcio continua até a oviposição no estágio 27, o que ocorreria para outros animais. De Marco (1992) acrescentou que a razão para a maior parte das espécies colocar os ovos perto do estágio 27 seria a necessidade da completa formação da casca. Packard et al. (1977) e Guillette (1982) ainda citaram as necessidades respiratórias e de crescimento do embrião como fatores responsáveis por esta característica.

Fatores abióticos relacionados a temperatura, umidade e disponibilidade de recursos podem também influenciar na retenção do ovo pelas fêmeas. Tais estratégias possivelmente são utilizadas para maximizar a sobrevivência das proles. O estágio da oviposição depende também de outros fatores tais como se existe um controle facultativo para a espécie ou em menor proporção pela influência de fatores indiretos como fenótipo de eclosão (Gutzke e Packard, 1987; Shine e Harlow, 1996; Elphick e Shine, 1998; Mathies e Andrews, 1999) e a capacidade de desempenho (Van Damme et al., 1992) em uma variedade de Squamata (Mathies e Andrews, 1999).

O período correspondente a fase de pré-oviposição representa aproximadamente 25$40 \%$ do período de desenvolvimento. Não seria surpresa cometermos o equivoco de inferir que tal característica seria indicativa de que ocorra uma menor quantidade de eventos nesta fase, sendo limitado este desenvolvimento. Outrora, segundo Shine (1983), a maior parte da diferenciação (65-80\% dos eventos) dos embriões ocorra ainda no interior do corpo da fêmea. Tal fato pode ser facilmente observado em I. iguana iguana e nas demais espécies relatadas nesta discussão visto que, nas descrições da primeira fase pós-oviposição, os embriões frequentemente apresentavam morfologia condizente à animais de outras espécies em estágios mais avançados de desenvolvimento (M. niger [Vieira et al., 2011], Emydura subglobosa [Werneburg, 2009], C. latirostris [Iungman et al., 2008], P. sinensis [Tokita e Kuratani, 2001]), com a presença de algumas dezenas de pares de somitos, brotos dos membros, vesículas encefálicas e arcos faríngeos.

Em vertebrados como Pariedura pictus (Noro et al., 2009), C. serpentina (Yntema, 1968), P. sinensis (Tokita e Kuratani, 2001), A. spinifera (Greenbaum e Carr, 2002), Gallus 
gallus domesticus (Hamburger e Hamilton, 1992), A. Mississippiensis (Ferguson, 1985, 1987), C. latirostris (Iungman et al., 2008), C. porosus (Magnusson e Taylor, 1980), Python sabae (Boughener et al., 2007), E. macularius (Wise et al., 2009) A. sagrei (Sanger et al., 2008) e P. pictus (Noro et al., 2009) dentre outros, os primeiros estágios foram determinados pelo surgimento das vesículas cerebrais primárias, placoides, arcos faríngeos e pelo número de somitos. Os estágios intermediários pela formação e desenvolvimento dos brotos dos membros, características craniofaciais e os últimos estágios pela diferença de pigmentação do corpo, padrões de desenvolvimento de escamas e de características espécie-específicas. Segundo Greenbaum e Carr (2002), tais características podem ser consideradas padrões para o desenvolvimento de embriões de répteis. Partindo deste pressuposto, nossa investigação teve como base tais caracteres para o desenvolvimento da tabela normal de desenvolvimento pósoviposição de I. iguana iguana.

Desta forma, foram descritos os estágios a partir do evento da oviposição. Neste momento os embriões de I. iguana iguana encontravam-se com os brotos dos membros em desenvolvimento inicial. Este período foi considerado o estágio 28 de acordo com as características presentes nos demais lagartos (Dufaure e Hubert, 1961; Noro et al., 2009; Wise et al., 2009) . As principais características estão apresentadas sumariamente na tabela II.

Comparações com outros táxons demonstram que o estágio para oviposição pode variar significativamente de acordo com a presença ou ausência de determinadas características nos embriões nesta fase de desenvolvimento. Em P. pictus (Noro et al., 2009) a oviposição corresponde ao estágio 22-24 de Lacerta (Dufaure e Hubert, 1961) e antecede ao estágio da formação dos brotos dos membros em A. sagrei (“Early limb-bud”) (Sanger et al., 2008). Segundo características estabelecidas com base na compilação dos resultados para o desenvolvimento de lagartos, o período "Early limb-bud" (estágio 4) seria comparado ao estágio 25-26 visto a ausência dos brotos dos membros. Em espécies como E. Macularius e C. versicolor a oviposição ocorre nos estágios 28-29 e 26 e 27, respectivamente (Noro et al., 2009) e em I. iguana iguana no estágio 27 (Tab. II).

Embora não tenham sido comtemplados nesta investigação, os estágios iniciais de desenvolvimento (1-27) estão descritos na literatura para outras espécies tais como Agama impalearis (Mouden et al., 2000), C. lateralis (Blanc, 1974), A. sagrei (Sanger et al., 2008), Liolaemus t. tenuis (Lemus e Duvauchelle, 1966) e Lacerta agilis exigua (Peter, 1904). Os caracteres avaliados antes da oviposição são da mesma forma importantes para determinação destes estágios. Formação e desenvolvimento da blástula e gástrula, organogênese e a completa formação do tubo neural e das vesículas cerebrais, início da formação dos arcos 
faríngeos e a somitogenêse. Segundo Wise et al. (2009) as condensações das vesículas óptica e auditiva estão presumidamente formadas, assim como o intestino fechado (Wise et al., 2009). Mesmo estes eventos iniciais não sendo contemplados para a descrição dos estágios iniciais em I. iguana iguana, alguns deles, principalmente a formação dos arcos faríngeos, vesículas cerebrais, membros, vesículas óptica e auditiva foram apreciados para a estruturação da sequência de eventos que originaram a tabela de desenvolvimento após a oviposição.

Andrews e Greene (2011) documentaram a embriologia de Uta stamburiana utilizando principalmente dados de formação e desenvolvimento do placoide óptico, formação dos brotos dos membros e arcos faríngeos. Greenbaum e Carr (2002) e Graham (2001) concordaram que a formação dos arcos faríngeos era significante para a determinação dos primeiros estágios. Todavia Andrews e Greene (2011) concluíram que não apenas um, ou o conjunto de características secundarias podem ser utilizadas para o estabelecimento de um padrão normal de desenvolvimento. Os autores ainda afirmam que o padrão de variação apresentando por estruturas como os arcos faríngeos e a capsula óptica são inesperados. Outrora, Werneburg (2009) citou estes como sendo caracteres chave para a descrição normal de uma tabela de desenvolvimento, sendo utilizados para as diversas espécies citadas, inclusive I. iguana iguana. Andrews e Greene (2011) ainda chamam a atenção para a utilização da pigmentação. Esta característica está inclusa em muitas das tabelas de desenvolvimento, mas não foram citadas como 'características mensageiras' por Werneburg (2009) ou Bibinda-Emonds et al. (2007). Para determinação e descrição dos últimos estágios em I. iguana iguana as diferenças na pigmentação e as alterações no aspecto geral com progressiva similaridade ao estado pós-natal foram as principais características utilizadas.

Dentre as principais alterações morfológicas que marcam o inicio da incubação, a formação e desenvolvimento dos membros é considerada uma característica que direciona a determinação dos estágios embrionários. Segundo Sanger et al. (2008), embriões de lagarto apresentam ambos os brotos membros em desenvolvimento no segundo dia. O primeiro estágio descrito para I. iguana iguana correspondendo ao estágio 28, primeiro dia de incubação. A sequência básica de desenvolvimento dos membros é consistente em $E$. macularius (Wise et al., 2009) A. sagrei (Sanger et al., 2008) e P. pictus (Noro et al., 2009). O broto do membro torácico surgiu antes do pelvino e este primeiro sempre foi maior que o segundo. Em E. macularius (Wise et al., 2009) ambos os brotos dos membros estavam desenvolvidos no estágio 29, sendo o broto torácico o primeiro a surgir. Em I. iguana iguana os brotos de ambos os membros estavam presentes no estágio 28, não sendo possível estabelecer com precisão a ordem de aparecimento. 
Müller (1985) observou que para os vertebrados no geral existe a tendência de formação do broto do membro torácico primeiro que do membro pelvino, exceto para tartarugas marinhas, que se desenvolvem simultaneamente. Outras investigações apontam que tal tendência existe, embora não possa ser tratada como padrão. Aves, morcegos, crocodilianos, testudines (Magnusson e Taylor, 1980; Hamburger e Hamilton, 1951; Beggs et al., 2000; Tokita e Kuratani, 2001; Iungman et al., 2008; Piña e Siroski, 2008; Vieira et al., 2011) formam o broto torácico primeiro. Para A. mississippiensis Ferguson $(1985,1987)$ relatou o membro pelvino como o primeiro a se desenvolver. Várias investigações com anfíbios também revelam que tal informação não se trata de um padrão (Shumway, 1940; Nieuwkoop e Faber, 1994). Em I. iguana iguana também não foi possível avaliar com precisão a ordem de aparecimento dos brotos, todavia a cronologia reflete, em todos os vertebrados, uma demanda funcional (McCrady, 1938).

Em geral as próximas etapas no desenvolvimento dos membros correspondem na autopodia, sendo possível a visualização da condensação dos dígitos, que para I. iguana iguana foi nítida no estágio 30, sendo para E. macularius no estágio 33 (Wise et al., 2009), para $P$. pictus entre o décimo quarto e décimo sexto dia de desenvolvimento (Noro et al., 2008) e para Anolis a fase de condensação ocorre no estágio 7 (Sanger et al., 2008). Após esta, a regressão da membrana interdigital e o surgimento dos primeiros indícios das garras, após o estágio 33 em I. iguana iguana, 35 em E. macularius (Wise et al., 2009), 10 em Anolis (Sanger et al., 2008) e em P. pictus a partir do vigésimo sexto dia de incubação (Noro et al., 2009).

Comparado com outros lagartos, o padrão de formação das escamas desenvolve relativamente cedo em E. macularius (Wise et al., 2009), com os membros torácicos com escamas completamente formadas no estágio 38. Todavia está característica não está presente em L. vivipara (Dufaure e Hubert, 1961) e em C. versicolor (Muthukkarruppan et al., 1970) até o estágio 39, assim como em I. iguana iguana. Do mesmo modo, escamas na cabeça aparecem primeiro em E. macularius (estágio 39) e depois em C. versicolor (estágio 41), podendo ser observadas apenas no estágio $41 \mathrm{em}$ I. iguana iguana. A abertura externa da narina é tardia em E. macularius (estágio 42) se comparada com C. versicolor (estágio 41) (Wise et al., 2009), embora em I. iguana iguana ela se abra apenas no estágio 43.

Em animais heterotérmicos a temperatura atua como um importante fator abiótico em diversas funções metabólicas, reprodutivas e durante o desenvolvimento. Para lagartos incubados a $28^{\circ} \mathrm{C}$ o desenvolvimento mostrou-se durar aproximadamente dois meses (Muthukkaruppan et al., 1970; Werner, 1971; Lemus et al., 1981; Viets et al., 1993; 
Thompson e Russel, 1999; Ji et al., 2002). Este período de incubação foi averiguado para lagartos Anoles (Sanger et al., 2008) e I. iguana iguana, embora este último tenha sido incubado a $30^{\circ} \mathrm{C}$, perfazendo setenta dias de incubação. Hubert (1985) sugeriu que estes resultados indicam que embriões de Anolis se desenvolvem mais rápido que outros lagartos quando consideradas suas diferenças na oviposição, que segundo o autor é provavelmente uma característica comum entre os lagartos. Como nos demais lagartos investigados, as variações anatômicas mais conspícuas durante o desenvolvimento ocorrem nos primeiros estágios. Os eventos relacionados com o final do período de incubação são mudanças na pigmentação, crescimento corporal, aparecimento do dente de ovo e inclusão do vitelo.

As variações na cronologia podem ser explicadas pelas diferenças no período de incubação, fatores abióticos como temperatura e umidade, sazonalidade, pela presença de interferências naturais ou artificiais durante a incubação (Crastz, 1982; Lang et al., 1989; Packard e Packard, 1984; Piña et al., 2007; Vieira et al., 2011). Embora existam disparidades, os resultados encontrados nas tabelas de desenvolvimento apresentam um potencial para comparação e avaliação em espécies distintas (Noro et al., 2009). 
Tabela II: Comparativo de características de desenvolvimento entre espécies de lagarto. (a) presente estudo; (b) Lemus et al., 1981; (c) Sanger et al., 2008; (d) Gregorovicova et al., 2012; (e) Noro et al., 2009; (f) Wise et al., 2009. ST, estágio baseado em Dufaure e Hubert (1961), SS, estágio descrito por Sanger et al. (2008); * sem comentários no artigo; ** dado obtido da imagem; n, não visualizado; p, pelvino; t, torácico; dpo, dias pos-oviposição.

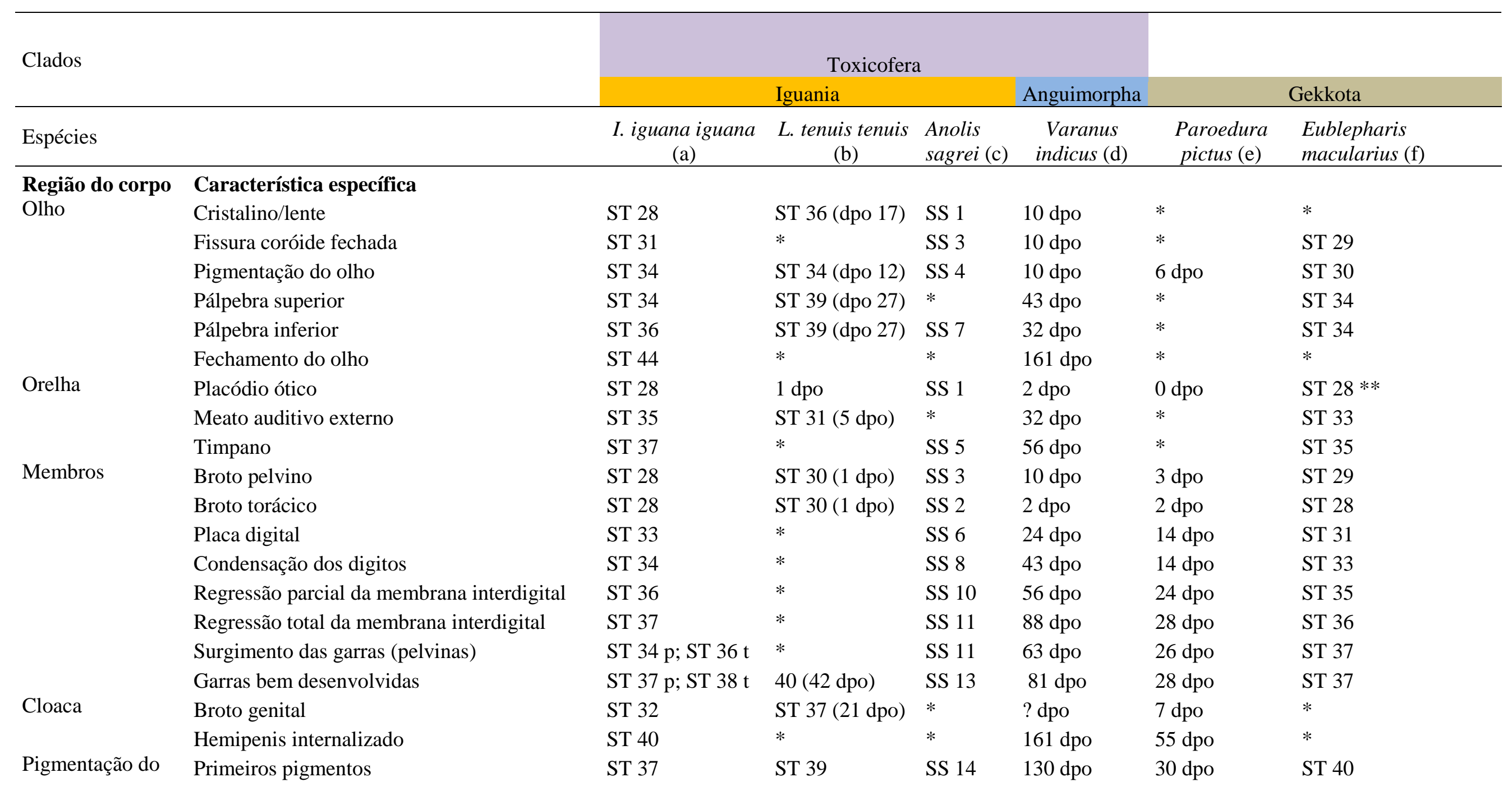




\begin{tabular}{|c|c|c|c|c|c|c|c|}
\hline corpo & Padrão & ST 41 & ST 41 (53 dpo) & SS 16 & $130 \mathrm{dpo}$ & $*$ & ST 40 \\
\hline \multirow{3}{*}{ Escamas } & Completa & ST 44 & ST 41 (53 dpo) & SS 18 & $161 \mathrm{dpo}$ & 40 dpo & ST 41 \\
\hline & Primeiros sinais & ST 38 & $*$ & SS 13 & 56 dpo & 18 dpo & ST 35 \\
\hline & Membros & ST 39 & ST 39 (27 dpo) & SS 13 & $56 \mathrm{dpo}$ & $*$ & ST 37 \\
\hline \multirow{3}{*}{ Rostro } & Cabeça & ST 41 & ST 40 & SS 14 & 81 dpo & $*$ & ST 39 \\
\hline & Dente de ovo & ST 42 & $\mathrm{n}$ & SS 13 & $161 \mathrm{dpo}$ & $*$ & ST 42 \\
\hline & Narina aberta & ST 44 & $*$ & $*$ & $\mathrm{n}$ & $*$ & ST 42 \\
\hline
\end{tabular}




\subsection{Anatomia e ontogenia do esqueleto}

\section{Crânio}

De maneira geral o crânio mantém as características de lagartos ancestrais. Os Iguanidae possuem o focinho alongado com um amplo processo ventral no osso esquamosal, ausência de fusão no tubérculo esfenoccipital e presença de uma fileira de dentes serreados (Conrad e Norell, 2010). Banzato et al. (2012), George e Smallwood (1992) relatam que o crânio de Iguana é grosseiramente triangular na vista dorsal e com uma pequena região préorbital, mesmas características encontradas em I. iguana iguana. Averiguamos ainda a proporção 1:1:2 com relação ao comprimento do focinho, órbita e crânio, assumindo esta estrutura uma forma triangular com a parte rostral bastante curta e robusta. Esta proporção para lagartos Teiidae é equivalente (Barberena et al., 1970; Tedesco et al., 1999; Evers Jr e Soares, 2007).

Iguanidae, Agamidae e Chamaeleonidae são caracterizados por possuírem crânios com focinho curto, largas orbitas e um pronunciado processo pterigóide. Outras famílias apresentam crânio estreito com focinho longo e pequenas órbitas (Herrel et al., 2007; Metzger e Herrel 2005). Jerez (2012) relata que indivíduos de Mabuya sp. apresentam focinho largo, que dentre outras, é uma característica da subfamília Lygosominae. Müller (2002) salienta que a anatomia dos lagartos do velho mundo é conservativa, principalmente na família Lacertidae. Dentre as espécies de lagartos, aquelas que apresentam tamanho reduzido possuem crânios largos e fundidos (Rieppel, 1984; Müller, 2002). Em I. iguana iguana o crânio pode ser considerado grande em relação ao grupo de lagartos no geral. As estruturas ósseas estão bem delimitadas e não existem processos aparentes de fusão, exceto na parte caudal e assoalho craniano.

Metzger e Herrel (2005) afirmam que a massa craniana em lagartos herbívoros é relativamente mais leve. De fato o crânio de I. iguana iguana possui um aspecto delicado e leve, outrora com ossos maciços e resistentes. Stayton (2005), com base em análises morfométricas do crânio de Iguana, relacionou estas características aos hábitos de forrageamento do grupo (King, 1996; Cooper e Vitt, 2002; Vitt et al., 2003). Embora apresentem crânios curtos, a mordida é forte, característica compartilhada com outros lagartos herbívoros que possuem mordida lenta. Entretanto, lagartos Scleroglossa tendem a apresentar crânios alongados e dieta insetívora compatível com sua mordida rápida.

Tal morfologia é justificada pelo encurtamento do focinho que, com a diminuição do comprimento da alavanca, ocorre uma vantagem mecânica sem aumento da força muscular 
(Herrel et al., 2007). Existem ainda algumas dificuldades em se estabelecer um padrão de crânio para lagartos herbívoros visto grandes variações relatadas, porém, semelhanças entre Igunidae e Agamidae revelaram uma convergência entre estes clados herbívoros (Stayton, 2005).

A diversidade morfológica craniana dos lagartos caracteriza-se pela presença e perda de elementos, por exemplo o quadradojugal (Rieppel \& Gronowski 1981; Herrel et al., 2007). Em nenhuma das descrições, inclusive para I. iguana iguana, foi relatado a presença deste elemento, que Müller (2002) associa a expansão do músculo adutor externo da mandíbula. A presença dos ossos septomaxila e supratemporal neste grupo é relatada em várias espécies (Stephenson e Stephenson, 1956; Jolie, 1960; Simões-Lopes e Krause, 1988; Jerez, 2012), inclusive em I. iguana iguana.

Nos lagartos o par de septomaxila esta posicionado na capsula olfatória, sobresposto pelos ossos nasais (Stephenson e Stephenson, 1956), mesma posição averiguada em I. iguana iguana, sendo em Liolaemus occipitalis localizado medialmente à capsula nasal, disposto ao longo do septo nasal (Simões-Lopes e Krause, 1988).

O nasal forma a cobertura dorsal da capsula olfatória, contatando os ossos pré-maxila, maxila, vômer, pré-frontal e frontal. Em Crocodilurus amazonicus o pré-maxila exibe um processo caudal que contata o osso frontal e separa os nasais (Evers Jr, 2007). Em I. iguana iguana e nos demais lagartos o contato dos nasais é amplo na linha mediana, embora exista um pequeno processo caudal no pré-maxila e outro rostral no osso frontal. Estes não estão fundidos em Uroplatus, Lygodactylus, Lepidodactylus, Ebenavia, Brookesia, Lanthanotus, Eremias knoxii e outros (Broom, 1935; Jolie, 1960).

O vômer ocupa ampla parte na região do palato. Ele contata rostralmente o pré-maxila e caudalmente o palatino. Espécimes de Mabuya sp. apresentam adultos com estes elementos fundidos em uma placa única (Jerez, 2007, 2012). Em L. occipitalis estes são reduzidos, semicirculares e limitam a borda medial da fenestra vomeronasal. Em I. iguana iguana a borda medial da referida fenestra é limitada pelo vômer mas este elemento é grande e subtriangular, acompanhando a forma do focinho. Jolie (1960) afirma que a fusão do vômer é uma característica individual ou relacionada a idade em alguns gêneros. Em Brookesia e Rhampholeon estes estão fundidos ao pré-maxila e, em Ohisaurus e Eumeces ocorrem dentes vomerianos, estes ausentes em Iguana.

Presente na maioria dos lagartos, o jugal apresenta formato geral de um arco grande e robusto com dois processos: maxilar e temporal, mas sua morfologia pode ser distinta em algumas espécies. Em Delma e Ophioseps estes não desenvolvem tal estrutura, premanecendo 
o arco orbital nestas espécies aberto. Sua superfície lateral apresenta-se perfurada por vários forames que transmitem ramos cutâneos dos nervos maxilares (Jolie, 1960; Simões-Lopes e Krause, 1988). O jugal foi perdido em alguns lagartos (Lydodactylus), permanence vestigial em outros (Pachydactylus) ou reduzido a uma lâmina delgada (Naultinus, Hoplodactylus, H. flavivindis, C. variegatus e G. gecko) (Jolie, 1960). Para estes últimos, apenas uma espícula transversal está presente, sem a projeção vertical que contata o pós-frontal, sendo parte substituida por um tendão em lagartos da Nova Zelândia (Stephendon e Stephenson, 1956). O jugal possui forma de lâmina, larga na parte rostral e se estende caudalmente contatando o pós-orbital, limitanto a borda lateral da órbita em I. iguana iguana, diferindo dos demais lagartos. O tamanho do crânio desta espécie em relação aos demais lagartos relatados acima provavelmente permite o desenvolvimento de um jugal amplo.

O osso maxila é grande e triangular em vista lateral, formando a maior parte da porção rostral (focinho) do crânio dos lagartos, tal como nos demais vertebrados, sendo o principal elemento associado a dentição (Jolie, 1960). Ele contata os ossos pré-maxila, jugal (quando presente), nasal, pré-frontal, lacrimal, palatino, ectopterigóide, vômer e septomaxila. Para tal apresenta processos como nasal, premaxilar e posterior (Simões-Lopes e Krause, 1988). Na margem labial possui um variado número de forames que dão passagem aos ramos do nervo alveolar superior e a artéria maxilar.

Formado a partir de duas placas ósseas que se fundem na linha mediana o pré-maxila no adulto é um osso ímpar que possui um processo caudal em forma de cunha que contata os nasais (Simões-Lopes e Krause, 1988). Segundo Jolie (1960) este osso pode ser bastante reduzido em camaleões ou grande nas espécies da família Scincidae, em Phyllurus e alguns Iguanidae, outrora I. iguana iguana possui apenas um elemento ósseo reduzido e que sustenta quatro dentes.

Outro elemento que se ossifica por meio de dois centros distintos que se fundem no adulto é o frontal. Em I. iguana iguana ele corresponde em uma ampla placa quadrangular fundida no teto craniano. Este limita a margem medial da órbita e contata rostralmente o préfrontal e nasal, e caudalmente contata o parietal formando uma sutura transversal. Jerez (2012), Simões-Lopes e Krause (1988), Stephenson e Stephenson (1956) e Parker (1879) relatam esta como uma característica geral para os lagartos.

Adultos de Pachydactylus, Saurodactylus, Ophioseps, Xantusside, Feylinia, Scincus, Eumeces, Lacerta, Diploglossus e Anguis foram descritos com frontais não fundidos (Jolie, 1960). Parker (1879) entretanto descreveu apenas um elemento fundido em Lacerta agilis, $L$. viridis, Zooteca vivipara (L. vivipara). Estas variações podem representar heterocronias 
comuns em alguns lagartos. I. iguana iguana possui dois centros de ossificação distintos para este osso mas logo no final do período de incubação já se apresentam fundidos.

Percorrendo a borda dorsal da órbita, o frontal apresenta um espessamento característico, formando leves cristas que delimitam uma calha para o canal olfativo (SimõesLopes e Krause, 1988). O forame pineal pode estar presente no osso frontal, no parietal ou ainda na sutura entre estes. Jolie (1960) relata este normalmente localizado entre o parietal e o frontal. Em Agamidae o forame pode ser inconspícuo ou ausente tal como em Leiolepis bellii, Gekkota, Xantusiidae, Teiidae, Feylinia e Anniella (Camp, 1923; Romer, 1956) e excepcionalmente largo em Uromastix. Em Chamaeleo este é envolvido completamente pelo osso frontal (Jolie, 1960), mesma localização relatada nesta investigação para I. iguana iguana, embora bem próximo da sutura frontoparietal. Em Liolaemus occipitalis (SimõesLopes e Krause, 1988) está sobre a referida sutura.

Outro elemento com anatomia conservada entre os lagartos é o parietal. Está localizado caudalmente ao frontal, possui formato retangular e limita o contorno medial das fenestras temporais. Embora tratada amplamente como uma sutura (inclusive exposto no parágrafo acima), Payne et al. (2011) averiguaram que o contato frontoparietal possui estrutura de uma sindesmose. Os autores ainda afirmam ser esta uma característica conservativa dos lagartos, tal como a presença de articulações sinoviais entre os ossos quadrado e articular, epipterigóide e pterigoide, basisfenóide e pterigoide.

Em Naultinus e Hoplodactylus o parietal não se funde (Stephenson e Stephenson, 1956), apresentando uma membrana na parte mediana deste osso em Naultinus. Os autores justificam tal variação visto a ausência de ossificação nestes gêneros. Em outras espécies, ou grupos tais como Aristelliger, Uroplatus, Gekko e Hemidactylus (McDowell e Bogert, 1954), Pygopus, Delma, Aphrasia e Xantusiidae (Romer, 1956) também não ocorre fusão das placas.

De acordo com Jolie (1960) o pré-frontal está sempre presente, mas pode fundir-se ao lacrimal, este último não evidente na maioria dos lagartos. Em I. iguana iguana ambos estão presentes e distintos na parte rostral da órbita tal como em L. occipitalis (Simões-Lopes \& Krause, 1988) e Parvilacerta parva (Müller, 2002). O lacrimal esta presente também em Lygodactylus, Naultinus, Hoplodactylus e H. flavivindis (Stephenson \& Stephenson, 1956), sendo inconspícuo em alguns Gekko, e ausente em Microsaura (Brock, 1940), Phrynosoma, alguns Agamidae, Brookesia (Siebernrock, 1895), Xantusia vigilis (Camp, 1923), alguns Scindidae e Cordylidae (Jolie, 1960). Rieppel (1992, 1994) relata que este osso de desenvolve tarde em Lacerta vivipara e L. agilis exigua, sendo muito pequenos nestas espécies. 
Uma condição basal em lagartos é a presença do pós-orbital e do pós-frontral, estando ambos presentes em I. iguana iguana, L. occipitalis (Simões-Lopes e Krause, 1988), Naultinus, Hoplodactylus, H. flavivindis, C. variegatus e G. gecko (Stephenson \& Stephenson, 1956). O pré-frontal pode estar fundido ao lacrimal podendo dificultar a identificação destes elementos na parte rostral da órbita (Jolie, 1960).

Presente na região do palato, o pterigóide possui características similares nos lagartos. É alongado formando a metade caudal do palato e, por meio de processos, oferece área para articulação com os ossos basisfenóide, epipterigóide, palatino, basipterigóide e quadrado. Ocasionamente estão presentes dentes no pterigóide (Camp, 1923), normalmente no processo palatino (Simões-Lopes e Krause, 1988). Em T. maculilabis, E. Carinata e T. capensis, T. bogerti, Plica umbra, Strobilurus torquatus, Tapinurus semitaeniatus, Uracentron azureum estes dentes estão presentes (Rao e Ramaswami, 1952, Skinner, 1973; Torres-Carvajal, 2003), tais como em I. guana iguana. Jolie (1960) afirma que em muitos Iguanidae, Teiidae, Lacertidae e outros não existem dentes na região do palato tal como descrito em Mesalina watsonana (Khosravani et al., 2011) e Mabuya sp. (Evers Jr, 2007), característica única para estas espécies (Mausfeld et al., 2002).

O esquamosal em I. iguana iguana é uma placa diminuta lateralmente disposta no crânio, formando a parte caudal da fenestra supratemporal. Característica similar foi ralatada para L. occipitalis (Simões-Lopes e Krause, 1988). Segundo Jolie (1960) o esquamosal está amplamente presente em lagartos, sendo amplo em Anguids e Eumeces e possuindo forma bifurcada em Agamidae, Iguanidae e Chamaeleo, outrora em I. iguana iguana não observamos tal morfologia. Stephenson e Stephenson (1956) relatam sua ausência em adultos de Naultinus e Hoplodactylus.

A mandíbula nos lagartos compreende num par de ramos unidos rostomedialmente por meio de uma sínfise. É formada, em cada antímero, por sete ossos, que apresentam um espaço interno, o canal da mandibular, onde se alojam a cartilagem mandidular (Meckel), o nervo alveolar inferior e a artéria mandibular interna (Bizarro e Soares, 2013). Os elementos esqueléticos são o esplenial, dentário, angular, suprangular, articular, pré-articular e coronóide, com variações descritas para algumas espécies (Simões-Lopes \& Krause, 1988). A forma da superfície articular do osso articular pode ser plana em Ameiva ocellifera (Bizarro e Soares, 2013), e Crocodilurus amazonicus (Evers Jr e Soares, 2007) ou concava em A. ameiva (Tedesco et al., 1999) e nos Teiidae no geral (Bizarro \& Soares, 2013). Em I. iguana iguana a superfície articular deste osso é leventeme concava, haja vista a forma ligeiramente convexa do osso quadrado, estabelecendo uma típica articulação sinovial (Payne et al., 2011). 
Semelhante dentre os lagartos, o dentário ocupa a região rostal da mandíbula e sustenta um número variado de dentes. A principal diferença entre Iguanidae e Agamidae é quanto a implantação da dentição (acrodonte e não pleurodonte), embora muitos Agamidae possuam alguns dentes pleurodontes na mandíbula (Banzato et al., 2012). São aproximadamente $20 \mathrm{em}$ L. occipitalis (Simões-Lopes e Krause, 1988) e 27 em I. iguana iguana. Fatores etários e individuais são responsáveis por esta variação. A face lateral do dentário apresenta alguns forames mentuais e sua borda ventral serve a origem dos músculos mandibulohióideo e genioglosso.

$\mathrm{Na}$ face medial da mandíbula está presente um reduzido osso esplenial. Em Anolis, Gekko, Xantusia e Mabuya é descrita a redução ou ausência do esplenial. Esta redução normalmente é acompanhada da redução e perda do angular (Simões-Lopes e Krause, 1988). Ambos os ossos estão presentes em I. iguana iguana, embora a característica de redução do esplenial seja conspícua.

Caudalmente a mandíbula é formada pelo articular, suprangular, angular e o suprangular. A fusão destes ossos é comum entre os lagartos. O suprangular, prearticular e articular são fundidos em Brookesia, Ophisaurus e Anniella (Cope, 1892; Jolie, 1960; Oelrich, 1956; Parker, 1879) mas em I. iguana iguana estão claramente individualizados mesmo nos animais adultos, outrora Camp (1923) relata que a fusão é uma característica exclusiva dos lagartos.

Os ossos que limitam a caixa craniana são o basioccipital, supraoccipital, exoccipital, opstótico (ou otoccipital, quando estão fundidos), parabasisfenóide, proótico, epiótico e orbitoesfenóide. Supraoccipital e basioccipital são ossos ímpares, e formam parte do teto e assoalho craniano, respectivamente. Este último contribui para a parte mediana do côndilo. Em Anolis, Scincus e Lygosma não é possível averiguar a sutura entre o basioccipital e o exoccipital, sendo o côndilo formado provavelmente apenas pelo basioccipital. Tal sutura é perfeitamente diferenciada em I. iguana iguana, evidenciando a contribuição de elementos ósseos distintos na formação do côndilo, padrão averiguado nos demais lagartos (Romer 1956, Torres-Carvajal 2003, Khosravani et al. 2011). Lateralmente nesta região está posionado o par de pro-óticos que, nos lagartos adultos, não apresentam divisão entre os demais ossos do neurocrânio (Simões-Lopes e Krause, 1988) e limitam lateralmente o forame magno.

Vários são os relatos de fusão de estruturas do neurocrânio (pro-ótico, opistótico e exoccipital principalmente). Todos estes elementos possuem centros de ossificação distintos e são, normalmente, diferenciáveis nos jovens (Stephenson e Stephenson, 1956). Sua fusão 
pode estar associada ao grau de ossificação do crânio nestes animais (Jolie, 1960).

O otoccipital é par e lateralmente disposto na face caudal do crânio. Em L. occipitalis ele é formado pela união do exoccipital e opistótico, sendo este último diferenciado em algumas espécies (Oelrich, 1956). Estes elementos estão fundidos em I. iguana iguana, tal como em Stenocercus guentheri (Torres-Carvajal, 2003), Varanus prisca (Head et al., 2009), Eremias persica, Measalina watsonana (Khosravani et al. 2011), Shinisaurus crocodilurus (Bever et al., 2005), Naultinus (Stephenson \& Stephenson 1956), Ctenosauria pectinata e Sator grandaevus (Oelrich, 1956; Etheridge, 1962) dentre outros. A fusão acontece ainda durante o desenvolvimento pré-natal em muitos lagartos (Maisano, 2001) mas pode eventualmente ocorrer em jovens tal como relatado para S. crocodilurus (Bever et al., 2005). Este elemento forma o terço lateral do côndilo e a borda lateral do forame magno, delimitando a parede caudolateral do crânio. O par de processos paroccipitais são amplos e lateralmente dispostos contatando os osso quadrado, parietal e esquamosal (Head et al., 2009). O opstótico, quando diferenciado, é muito reduzido (Stephenson e Stephenson, 1956), embora nenhuma das descrições, inclusive para I. iguana iguana tal morfologia tenha sido observada.

Contribuindo na delimitação da margem rostral do processo paroccipital, o pró-otico forma a parede anterolateral do neurocrânio nos répteis em geral (Stephenson e Stephenson, 1956, Torres-Carvajal 2003, Bever et al. 2005, Bell et al. 2009, Head et al. 2009, Khosravani et al., 2011). Na transição com a região orbital, o orbitoesfenóide (lateroesfenóide, Romer, 1956) é uma ossificação da parte dorsal da pila metótica, localizada na parte anterior da caixa craniana que contribui para a formação da parede posterior da órbita (Bellairs e Kamal, 1981, Torres-Carvajal, 2003, Bell et al., 2009).

Nos répteis, tal como em I. iguana iguana, trata-se de um pequeno par de ossos curvados que se formam próximo a linha mediana, anteriormente ao parabasisfenóide e medialmente aos epipterigóides. Bever et al. (2005) relatam sua presença em S. crocodilurus, embora Conrad (2004) e outros autores não tenham descrito o orbitoesfenóide na referida espécie. Em Xenosaurus sua presença é variável, e a ausência é relatada em Gekkota, Heloderma e Anniella (Jolie, 1960), representando provavelmente variações intraespecíficas ou mesmo problemas durante o preparo do material. Tarazona et al. (2008) relatam que em Bachia bicolor tratam-se de um largo e laminar par de ossos posicionados próximo a linha mediana, fechando rostralmente o neurocânio. Tal característica é similar as espécies do grupo Amphisbaenia e diferente dos demais répteis, onde estes normalmente não contatam outros ossos do crânio.

O parabasisfenóide foi descrito em diversos lagartos (Head et al., 2003) e com a mesma 
topografia encontrada em Iguana, anterolateral na base do neurocânio. Abriga a cela turca, bem como os forames para artérias cerebrais e o nervo craniano VI. As relações filogenéticas e a anatomia deste elemento apresentam uma extensa discussão (Jolie, 1960; Bellairs e Kamal, 1981). O padrão atribuído aos répteis é a fusão do paresfenóide e basisfenóide formando este elemento ímpar. Eremias persica, Measalina watsonana (Khosravani et al., 2011), Varanus (Head et al., 2003), S. crocodilurus (Bever et al., 2005), Moloch horridus (Bell et al., 2009) e I. iguana iguana apresentam os elementos paresfenóide e basisfenóide fundidos formando um único parabasisfenóide (Rieppel, 1993; Torres-Carvajal, 2003).

Em Chamaeleo o paresfenóide é distinto, embora seja pouco desenvolvido. O processo cultriforme (rostro parabasisfenóide) está usualmente fundido a placa basal, podendo ser laminar ou como em Iguana, afilado e projetado rostralmente, alcançando a metade da extensão da órbita. Bever et al. (2005) relatam que em S. crocodilurus existe uma fontanela basicranial em alguns espécimes que apresentam uma área não ossificada na sutura basioccipital. Possivelmente seja uma heterocronia, haja vista não ser uma exclusividade da espécie e estar relacionado a idade dos espécimes. Nos exemplares de I. iguana iguana que avaliamos, todos adultos, a sutura estava visivelmente bem ossificada.

O crânio de I. iguana iguana possui forma triangular, focinho curto e as proporções entre os segmentos do crânio são parecidos, tal como na maioria dos lagartos. Tais informações poderão ser utilizadas como subsídio para investigações de caráter filogenético bem como para confirmação das características gerais do grupo e da espécie.

Nos vertebrados, a ossificação do crânio antecede os demais elementos do esqueleto (Rieppel, 1992a, b, 1993, 1994b; Lobo et al., 1995; Abdala et al., 1997; Rieppel e Zaher, 2001; Maisano, 2002a; Federico e Lobo 2006; Lobo et al., 2010; Hugi, et al., 2010). Embora a sequência de formação dos elementos apresente variações conspícuas, é possível observar um padrão relativamente definido para os lagartos.

O primeiro elemento do crânio a se formar é o pterigóide em Chamaeleo, Zooteca vivipara, Liopholis whitii, Tupinambis merianae, T. rufescens, Rachylepis capensis, Liolaemus scapularis, L. quilmes, Lacerta agilis exigua, Elgaria coerulea, Liopholis whitii, Ptychoglossus bicolor e I. iguana iguana (Skinner, 1973; Rieppel, 1992, 1993, 1994; Good, 1995; Lobo et al., 1995; Abdala et al., 1997; Arias e Lobo, 2006; Federico e Lobo 2006; Hugi et al., 2010; Hernández-Jaimes et al., 2012).

Outros elementos iniciam sua ossificação em simultâneo com o pterigoide em $L$. scapularis (ossos dérmicos da mandíbula), Chamaeleo (angular), L. quilmes (dentário e suprangular), Zooteca vivipara (palatino, premaxila e maxila) e I. iguana iguana (maxila, 
dentário, pós-orbital, jugal e suprangular) (Rieppel 1992, 1993; Lobo et al., 1995, 2010; Leal et al., 2010; Hugi et al., 2010, 2012). Trata-se de uma característica dominante na osteogênese do crânio dos vertebrados. Os elementos do dermatocrânio e aqueles associados a mandíbula se ossificam primeiro (Rieppel 1987, 1992, 1993, 1994; Vieira et al., 2010; Lima et al., 2011a; Sheil 2003).

Diferenças significativas foram relatadas em L. scapularis onde os elementos do póscrânio se ossificam primeiro que do crânio, diferente do observado para os demais lagartos (Lobo et al., 2005, 2010). Em I. iguana iguana o crânio inicia sua ossificação no estágio 36 e os elementos do pós-crânio somente a partir do estágio seguinte.

Depois do dermatocrânio, os primeiros ossos do viscerocrânio (quadrado) e do neurocrânio (exoccipital) iniciam sua formação (Rieppel 1992, 1994; Lobo et al. 1995; Abdala et al. 1997; Federico e Lobo 2006). Hugi et al., (2010) descrevem em L. whitii uma sequência um pouco distinta onde o primeiro elemento a se ossificar é o supraoccipital e posteriormente o dermatocrânio, representado pelo pterigóide e alguns ossos mandibulares (suprangular, angular e dentário).

Em Lacerta e Cyrtodactylus o primeiro elemento do neurocrânio a se ossificar é o exoccipital (Rieppel, 1992). Hugi et al., (2010) descreveram para L. whitii o basioccipital como primeiro, seguido pelo exoccipital. O quadrado e o exoccipital são os primeiros em $L$. quilmes e o orbitosfenóide o último. Em L. scapularis todos, exceto o supraoccipital, se ossificam no mesmo estágio (Lobo et al., 2010). Em L. agilis exigua o exoccipital, quadrado e epipterigóide são os primeiros, seguidos pelos basisfenóide e basioccipital, e em E. coerulea basioccipital e exoccipital são os primeiros e o orbitosfenóide o último. Muito similar a $I$. iguana iguana onde o basiocciptal, supraoccipital, parabasisfenóide e exoccipital (associado ao opstótico e nominado otoccipital) aparecem simultaneamente no estágio 38 e o orbitoesfenóide apenas no estágio 41. Tais relatos, embora apresentem variações menores, são muito similares, permitindo concluir que a sequência é, de certa maneira, conservada entre os lagartos (Maisano 2001; Jerez, 2007; Tarazona et al., 2008).

Em Lacerta o jugal inicia sua ossificação pela parte anterior, em contraste com $I$. iguana iguana e outros lagartos, onde sua forma é reduzida e a ossificação inicia pela parte média da estrutura (Rieppel 1981, 1992, 1994). O osso lacrimal está reduzido ou ausente nos lagartos. Em I. iguana iguana ele se forma após os demais ossos do dermatocrânio, tal como em L. quilmes e representa apenas uma pequena estrutura na parte rostral da órbita. $\mathrm{O}$ articular é o último a se ossificar no crânio de L. scapularis (Lobo et al., 2010).

O processo de ossificação dos ossos parietal e frontal foram relatados para outros 
lagartos e aqui para I. iguana iguana. Nestes, o frontal se forma por meio de dois centros de ossificação distintos posicionados na margem da órbita e progressivamente se expandem até se ossificar completamente na maioria das espécies (Rieppel, 1993). Segundo Machado (2012), a fusão dos ossos frontais é completa antes da eclosão em todas as Iguania, diferente do relatado para Scleroglossa, que finda a fusão apenas no período pós natal (Maisano, 2001).

Algumas espécies de Phelsuma podem apresentar o frontal formado por um processo de ossificação ímpar (Kluge, 1967), mas esta parece ser uma caracteristica exclusiva deste grupo, haja vista que, embora o frontal seja único em Hemidactylus mabouia, Hemidactylus flaviridis, Z. vivipara, L. agilis exigua, Cyrtodactylus, L. whitii, Liolaemus, Hemiergis, Ptychoglossus bicolor, I. iguana iguna e outros, durante a ontogenia ele é derivado de dois processos de ossificação distintos que se fusionam para formar um elemento único no adulto (Mahendra, 1949).

Durante a formação do teto craniano, o desenvolvimento do parietal ocorre gradativamente pelas porções laterais, por meio de centros de ossificação individualizados e ambas as margens.

Segundo Machado (2012) a presença de um par de parietais é uma característica restrita. Embora nas descrições do crânio exista apenas um parietal nos adultos de Varanus, Lacerta, Uromastix, Tupinambis, Calotes e I. iguana iguana, durante a ontogenia este elemento se forma por meio de mais de um centro de ossificação na maior parte destes animais. Esta característica é compartilhada com outros lagartos (Rieppel 1992, 1993; Lobo et al., 1995, 2010; Leal et al., 2010; Hugi et al., 2010, 2012, Machado, 2012). Mahendra (1949) relata o parietal par em alguns geconídeos, uroplatídeos e xantusídeos.

A incompleta fusão dos centros de ossificação do elemento frontoparietal evidencia a formação da fenestra frontoparietal, que permanece no estágio posterior a eclosão. Trata-se de uma característica quase constante nos lagartos e sua extensão varia de acordo com o grau de ossificação dos ossos parietal e frontal (Maisano, 2001). Em Iguania ela se fecha apenas nos adultos (Maisano, 2001; Torres-Carvajal, 2003). Segundo Rippel, (1994) o precoce desenvolvimento dessa região temporal marginal está relacionado ao desenvolvimento dos músculos adutores da mandíbula, e que o completo fechamento da fenestra é devido ao desenvolvimento do encéfalo.

Foi relatado uma grande fenestra em Chalcides ocellatus, Calotes versicolor, Podarcis muralis, Bachia bicolor, Ptychoglossus bicolor, Larcerta, Chamaleo hoehnelle, Hemidactylus mabouia e I. iguana iguana (Ramaswami 1946; El Toubi e Kamal, 1959; Rieppel, 1987, 1993, 1994; Tarazona et al. 2008; Machado 2012), contudo em Potamites ecpleopus é 
pequena (Maisano, 2001) e em Acontias meleagris, Aniella pulchra e Bipes biporus ausente (Bellairs e Kamal, 1981; Maisano, 2001; Torres-Carvajal, 2003).

Tal fenestra regride porém não oclui completamente, dando origem o forame parietal nos adultos de I. iguana iguana, Xantusia henshawi e Xantusia vigilis vigilis, Z. vivipara (Rieppel, 1992, Maisano 2002). Sua completa obliteração é descrita em Hemidactylus mabouia, Lepidophyma gaigeae, Xantusia riversiana, X. vigilis arizonae e B. bicolor (Tarazona et al., 2008). Segundo Bellairs e Kamal (1981) todas as diferenças associadas a ossificação do crânio refletem o modo de vida das espécies.

A sequência de formação do esqueleto reflete a demanda funcional dos animais. A ossificação do crânio em anuros, por exemplo, atende as necessidades dos elementos envolvidos com a respiração (Mabee et al., 2000), e em peixes teleósteos, também com a alimentação, incluindo as espécies que apresentam estratégias peculiares de alimentação, seguidos por aqueles associados a suporte e depois aqueles de proteção (Weisel, 1967; Gaudin, 1978). Padrão similar é averiguado em I. iguana iguana, que inicia sua ossificação pelos ossos pterigóide, os elementos dérmicos da mandibular e a maxila.

\section{Vértebras}

O segmento da coluna vertebral nos répteis apresenta diferenciações regionais que levam a distinção das vértebras em regiões pré-sacral, sacral e caudal (Romer, 1956). A região pré-sacral ainda pode ser subdividida em cervical, dorsal ou torácica e lombar (Krause, 1978), tal como pode ser durante o desenvolvimento e nos adultos de I. iguana iguana.

A ossificação da coluna vertebral está claramente associada ao gradiente crânio-caudal nos vertebrados (Mohammed 1988, Rieppel, 1992, 1994; Federico e Lobo 2006; Hugi et al., 2010; Lobo et al., 2010; Vieira, 2011; Lima et al., 2011c). Lobo et al. (2010) relataram para Liolaemus ssp. que as vértebras se ossificam todas no mesmo estágio. Provavelmente o reduzido número de amostras e o intervalo entre os embriões observados reflete este resultado. Nesta investigação a sequência apresentada por I. iguana iguana reflete o padrão crânio-caudal descrito nos demais trabalhos. Os primeiros centros de ossificação estão presentes após o início da ossificação do crânio.

Condrogênese e ossificação iniciam pelo centro vertebral, seguidos pelos arcos vertebrais e costelas. O centro vertebral se ossificação pela parte ventral pelo processo 
pericondral (Rieppel, 1994). Em L. quilmes o centro vertebral, costelas cervicais, costelas dorsais e costelas caudais começam se ossificar antes do arco neural, no mesmo estágio (Abdala et al., 1997).

Segundo os relatos de Hugi et al. (2010), para os Squamata não existe diferença no tempo de ossificação entre as vértebras e as costelas. Em L. scapularis os autores verificaram que o centro vertebral também inicia sua ossificação antes dos arcos vertebrais e costelas, tal como relatado para I. iguana iguana. De acordo com Mohammed (1988) o arco vertebral finda sua ossificação por meio de centros secundários em $C$. ocellatus, fato que não foi observado em I. iguana iguana.

A ossificação das costelas sacrais e dos processos transversos caudais é contínua com o arco vertebral em lagartos. Em Sphenodon, Alligator (Rieppel, 1992) e Melanosuchus (Vieira, 2011) a formação destes é distinta a estrutura do arco vertebral, sugerindo a presença de costelas livres nestes animais, diferente do observado para lagartos (Rieppel, 1992). A formação desta estrutura em I. iguana iguana ocorre por meio de centros de ossificação distintos no centro vertebral, arco vertebral e costelas sacrais. Durante os estágios posteriores as costelas sacrais em avançado processo de formação contatam o centro vertebral mas não se fundem a ele.

Quanto ao desenvolvimento deste segmento da coluna, a condensação cartilagínea da costela é individual e se une posteriormente a vértebra no nível da futura articulação neurocentral, diferente das costelas cervicais e dorsais, onde os pontos de conexão se dão no capítulo e tubérculo da respectiva vértebra (Vieira, 2011).

Esta morfologia corrobora a descrição de Mohammed (1988) para C. ocellatus, onde o sacro representa duas vértebras livres como nos demais Iguanidae, Agamidae e Lacetilia, embora Hoffstetter e Gasc (1969) tenham reportado a fusão destas vértebras na referida espécie. I. iguana iguana apresenta somente duas vértebras sacrais que se articulam com uma respectiva costela sacral e esta com a pelve. Estas vértebras no adulto estão firmemente associadas mas não fundidas.

A formação destas estruturas por meio de centros de ossificação separados é uma característica pleisiomórfica com os lagartos (Currie e Carroll, 1984; 1988; Laurin, 1991). Em crocodilos jovens, Testudines e Sphenodon os processos transversos encontram-se ainda separados das vértebras, sendo considerados homólogos as costelas. Para crocodilianos, Higgins (1923) demonstrou uma relação de homologia, discordando de Huene (1908), que observou em indivíduos jovens o processo transverso suturado a vértebra, assim como em alguns lagartos. 
Segundo Gauthier et al. (1988), a ossificação das costelas sacrais e processos transversos caudais (costelas caudais) a partir de centros de ossificação distintos representa o estado plesiomórfico dos Lepidosauromorphos e os Archosauromorphos.

$\mathrm{O}$ desenvolvimento das vértebras caudais é semelhante às demais. Existe uma condensação cartilagínea independente para formação do processo transverso (costela caudal) confirmanda pelos estudos de Higgins (1923) e Emelianov (1937) para crocodilos e squamatas. Em I. iguana iguana foi possivel confirmar esta observação. O desenvolvimento das vertebras caudais é resultado de centros de ossificação no centro vertebral, arco vertebral e costelas caudais, resultando na foramação de uma sutura entre estas estruturas nos indivíduos adultos.

Rieppel (1993b) observou que os processos transversos das vértebras dorsais também se ossificam com centros distintos do arco vertebral que os processos transversos destas vertebras se fundem ao arco vertebral. Em M. niger (Vieira 2011) e em I. iguana iguana os processos transversos das vertebras dorsais se desenvolvem em continuidade com o arco vertebral.

\section{Ossículos da esclera}

Peixes teleósteos e répteis (incluindo aves mas excluindo serpentes e crocodilianos), possuem em sua esclera pequenos ossos que se dispõe de maneira circular e são demoninados ossículos da esclera.

Nos répteis essas estruturas são limitadas a margem anterior do globo ocular. A função do anel ósseo, bem como de cada placa individual é ainda pouco conhecida (Zhang et al., 2012). É proposto que esta estrutura protege a córnea contra pressão e mantém a forma do globo ocular. Outros autores consideram ainda que em sua parte anterior eles dão suporte aos músculos ciliares, sugerindo papel de acomodação da córnea. O número, forma, arranjo é distinta nos vertebrados (Creuzet et al., 2005).

A ausência de ossículos em alguns taxon pode ser uma caracterisitca que representa uma perda secundária dos Sarcopterygii basal (Walls, 1942; Franz-Odendaal e Vickaryous, 2006).

São estruturas originadas a partir da crista neural (ectomesenquimal), por meio de um espessamento do epitélio conjuntivo denominado papila escleral (Coulombre et al., 1962). Os ossículos da esclera de tetrapoda se ossificam de maneira intramembranosa e I. iguana iguana corrobora essa informação (Franz-Odendaal e Vickaryous, 2006). 
O número é bastante variável e normalmente pode contribuir com informações taxonômicas. Em répteis a menor reportada é de 6 placas (testudines) e a maior de 18 (aves) (Lima et al., 2009; Fraz-Odendaal e Vickaryous, 2012; Vieira et al., 2007). Em I. iguana iguana e Lacerta (Rieppel, 1992, 1994) foram reportadas a presença de 14 placas quadrangulares. Para testudines a quantidade varia de 6 a 13 (Vieira et al., 2007) e em aves de 11 a 18 (Coulombre e Coulombre, 1973; Lima et al., 2009).

Em contraste, nos teleosteos modernos o número de ossículos é bem menor, variando de 1 a 4 (2 normalmente) e com desenvolvimento diferente do apresentado pelos répteis (Nakamura e Yamaguchi, 1991), e que possivelmente confirma a não homologia entre estas estruturas para ambos os grupos (Fraz-Odendaal e Vickaryous, 2012).

Os ossículos permanecem ausentes em I. iguana iguana nos primeiros estágios avaliados. No estágio 32, apenas alguns ossos do crânio apresentam centros de condensação cartilagínea evidentes. Nos estágios subsequentes novas estruturas cranianas são evidenciadas, mas somente a partir do estágio 36, ocorre a primeira evidência do início do surgimento dos ossículos da esclera de I. iguana iguana. É consenso que nos répteis a ossificação dos ossículos da esclera ocorre via intramembranosa (Franz-Odendaal e Hall, 2005; Franz-Odendaal, 2008).

De acordo com Jabalee et al. (2013) e Zhang et al. (2012) a condensação celular para formação dos ossículos é visualizada pela primeira vez no estágio 36 e continua sua formação até o estágio 38, quando a mineralização ocorre. Em I. iguana iguana essa característica ocorre mais cedo. No estágio 36 os elementos ósseos já apresentam retenção de corante, embora os espécimes submetidos a análise histológica tenham confirmado o início da ossificação apenas no estágio 38.

Existem evidências apresentadas por Jabalee et al. (2013) de que mecanismos que regulam a migração celular do mesênquima, aumenta o número de osteoblastos dentro da zona de condensação. Estes autores conseguiram mostrar o arranjo de células no eixo que se direciona a condensação. Observando os cortes na região da esclera de I. iguana iguana pudemos notar que algumas dessas células apresentavam-se tal como relatado pelos autores. Esta migração ocorre em sincronia com a secreção esteóide na área dos ossículos.

Hall e Miyake (1995) e Duprez et al. (1996) sugerem que é provável o recrutamento dessas células por vias moleculares, e não de maneira aleatória. Ferretti et al. (2002) concluem ainda que, sendo a condensação osteogênica o processo que origina os ossículos da esclera, neste caso existe uma interação de osteoblastos dinâmicos e estáticos, visto que grande parte dessas células são polarizadas e organizadas e apenas algumas permanecem 
estáticas.

Adicionalmente, alguns autores (Levrat-Calviac e Zylberberg, 1986; Zylberberg et al., 1992) reportaram que o desenvolvimento desta estutura é o resultado de uma transformação direta da derme em osso, via um modelo incomum de osteogenese que involve metaplasia.

\section{Esqueleto apendicular}

A sequência de ossificação dos cíngulos peitoral e pélvico são bem definidas. No membro anterior, a clavícula se ossifica primeiro, seguida pela interclavícula. Em estágios posteriores a formação da escápula antecede a do coracóide (Mathur e Goel, 1976; Mohammed, 1988; Rieppel, 1992a, b, 1993, 1994; Mohammed et al., 1995; Lobo et al., 1995; Abdala et al., 1997; Maisano, 2002 a, b; Shapiro, 2002; Federico e Lobo 2006; Fabrezi et al., 2007; Jerez e Tarazona, 2009; Hugi et al., 2010; Leal et al., 2010; Lobo et al., 2010). Visto que esta característica foi comum em todos os lagartos relatados, inclusive em I. iguana iguana, o padrão de ossificação para este segmento em lagartos é muito claro.

A clavícula começa a se ossificar enquanto a cartilagem da interclavícula ainda está se formando. Isso explica, possivelmente, porque em lagartos onde ocorre redução dos elementos, a interclavícula pode estar ausente, visto que os últimos elementos a se formam são os mais susceptíveis a desaparecer nestes processos (Rieppel, 1992). O coracóide e escápula são separados. A ossificação ocorre via endocondral na cintura peitoral e no esterno (Jerez e Tarazona, 2009).

Na cintura pélvica, o íliaco é o primeiro elemento a se ossificar, seguido pelo pubis e ísquio. Neste segmento quando existe redução o primeiro elemento a desaparecer é o isquio, confirmando o supracitado por Rieppel (1992). Apenas em H. peronii foi relatado uma sequência diferente dos demais lagartos, onde o pubis é o primeiro elemento a se formar na pelve (Hugi et al., 2012). Em I. iguana iguana, estes três elementos estão presentes na estrutura da pelve e se ossificam no mesmo padrão relatado para os demais lagartos, ratificando a existência de um arranjo bem estabelecido e conservado para a ossificação das cinturas em lagartos.

Os lagartos mostram um gradiente próximo-distal conservativo (Rieppel, 1993a; Mohammed et al., 1995; Maisano, 2002a; Federico e Lobo, 2006; Hugi et al., 2010). Úmero/fêmur, radio/tibia, ulna/fibula se ossificam em um gradiente próximo-distal (Mathur e Goel, 1976; Mohammed 1988; Rieppel 1992a, b, 1993, 1994; Mohammed et al. 1995; Lobo et al. 1995; Abdala et al. 1997; Maisano, 2002 a, b; Shapiro, 2002; Federico e Lobo 2006; 
Fabrezi et al., 2007; Jerez e Tarazona 2009; Hugi et al., 2010; Leal et al., 2010; Lobo et al., 2010).

Embora alguns autores relatem os eventos de ossificação destes segmentos como simultâneos (Rieppel, 1992, 1994), acreditamos que o intervalo de observação e a quantidade de embriões analisados possa causar esse viés. Para I. iguana iguana, uma primeira análise foi observado a ossificação do membro torácico simultaneamente no embrião. Uma analise posterior com intervalo reduzido entre os embriões (maior número de amostras), a retenção de alizarina no úmero foi visualmente maior que no radio e ulna.

A diáfise dos ossos dos membros se ossificam via pericondral e as epífises são invadidas em estágios posteriores por centros de ossificação secundários (Hugi et al., 2010; Leal et al., 2010). Até o final do período de incubação de I. iguana iguana, apenas o fêmur e o úmero possuíam suas epífises marcadas para centros de ossificação segundário. Na maioria dos lagartos, esta característica ocorre no estágio pós eclosão, quando o esqueleto termina sua formação e os centros de ossificação secundários são mais abundantes (Maisano, 2002b).

\section{Membro torácico}

O desenvolvimento inicial do esqueleto cartilagíneo dos Tetrapoda é caracterizado por eventos específicos e invariáveis no padrão de condensação condrogênica (Mathur e Goel, 1976; Burke e Alberch, 1985; Shubin e Aberch, 1986; Fabrezi et al., 2007; Vieira et al., 2010). Os novos elementos do esqueleto normalmente não se diferenciam como condensações independentes, ocorrendo a diversificação através de células mesenquimais já existentes em uma sequência descrita como genérica para alguns grupos de vertebrados (Shubin e Alberch 1986; Oster et al., 1988; Müller e Alberch 1990).

É consenso que para lagartos (Mathur e Goel, 1976; Shapiro 2002; Fabrezi et al., 2007) e outros Tetrapoda (Shubin e Aberch, 1986) que o desenvolvimento dos membros ocorre de maneira similar, com a presença do eixo primário e arco digital, embora algumas diferenças sutis possam ser observadas durante a morfogênese (Leal et al., 2010). A partir da observação destas características em I. iguana iguana podemos confirmar que, dentre as espécies analisadas, este é certamente um padrão para o grupo.

A característica mais estável do desenvolvimento deste segmento é a formação do eixo primário descrito para crocodilianos, anfíbios, aves, lagartos e testudines (Mathur e Goel 1976; Hinchliffe 1977; Müller; Alberch 1990; Rieppel 1992, 1993, 1994; Shapiro 2002; 
Fabrezi et al., 2007; Sanchéz-Vilagra et al., 2007; Leal et al., 2010; Vieira et al., 2010). Nos estágios iniciais da morfogênese as células mesenquimais se organizam sistematicamente em uma estrutura que, no sentido proximo-distal, condensa-se em um eixo em Y na região do zeugopódio e estilopódio.

Nos lagartos em geral, a morfogênese dos membros tem início nos estágios iniciais. A extremidade distal do broto do membro ainda não apresenta dilatação referente a formação do arco digital e consequentemente não existem condensações nesta região. Em I. iguana iguana esta fase tem início logo após a oviposição, no estágio 28 sendo em Gonatodes albogularis e Mabuya ssp. no estágio 29 (Leal et al., 2010).

As variações no estágio de formação do eixo primário normalmente podem refletir diferenças na classificação dos estágios ou alterações mínimas nas condições de incubação dos embriões, porém mantendo o padrão conhecido e relatado. Portanto, em $H$. initialis (Shapiro, 2002), Z. vivipara e L. agilis exigua (Rieppel, 1992, 1994), B. bicolor (Jerez e Tarazona, 2001), L. whitii (Hugi et al., 2010), G. oceanica (Rieppel 1994a), T. marianae (Federico e Lobo, 2006), C. versicolor (Mathuer e Goel, 1976 ), Hemiergis ssp. (Shapiro, 2002) e C. ocellatus (Mohammed, 1991), Mabuya ssp. (Leal et al., 2010), C. pubisulcus (Rieppel, 1992), C. hoehnelii (Rieppel 1994a) e I. iguana iguana a formação do eixo primário com a condrogênese dos elementos úmero, rádio e ulna são constantes como o primeiro evento na formação do arcabouço dos membros (Rieppel, 1992a, b, 1993, 1994; Lobo et al. 1995; Mohammed et al., 1995; Abdala et al., 1997; Maisano 2002 a, b; Federico e Lobo, 2006; Hugi et al., 2010).

Embora Leal et al. (2010) tenha relatado que no espécimes de G. albogularis avaliados a cartilagem do rádio é menos marcada em relação a cartilagem ulnar, em I. iguana iguana não foi possível avaliar esta característica.

Distalmente o broto do membro se expande ocorrendo nesta fase a segmentação da parte distal da cartilagem da ulna, formando o ulnar. No mesmo sentido, distal ao ulnar, a cartilagem segmenta-se dando origem ao distal do carpo IV que alonga-se e desta cartilagem segmenta-se o metacarpo IV, caracterizando assim o eixo primário (Burke e Alberch, 1985; Shubin e Alberch, 1986). Descrevemos este padrão de diferenciação do membro pela morfogênese do eixo primário com sequência próximo distal (úmero, ulna, ulnar, dcIV, mc4) para I. iguana iguana, corroborando os demais trabalhos descritos na literatura (Shapiro, 2002).

A morfogenese das cartilagens parece ocorrer durante a fase de expansão distal do membro (Mathur e Goel, 1976; Shapiro, 2002). Os lagartos no geral apresentam o 
desenvolvimento do mesopodio dentro dos eventos comuns aos amniotas tais como a formação do eixo primário e arco digital, dados que reforçam que o desenvolvimento dos membros dos lagartos é conservativo em sua formação e com variação limitada. Segundo Shapiro (2002) algumas heterocronias podem ser relatadas ou ainda a ausência de ossificação em alguns elementos, o que não implica na alteração do padrão de formação do membro.

A condrogênese dos elementos distais de I. iguana iguana é similar a de outros lagartos (Mathur e Goel, 1976; Rieppel, 1992a,b, 1993b, 1994b; Shapiro 2002), contudo, muitos autores apresentam ideias distintas com relação a algumas características pontuais durante a ontogenia dos membros torácicos. Ocorrem variações no autopodio com que diz respeito a dominância entre os elementos e também diferenças na composição estrutural, com a presença de condrogêneses e fusões durante a ontogenia.

Após a formação do dcIV, nos estágios seguintes as condensações referentes aos dcIII, dcII e dcI segmentam-se no sentido axial oriundo do dcIV, compondo totalmente o eixo primário. Este padrão foi descrito para G. albogularis, Mabuya ssp., Agama, C. versicolor, Hemiergis ssp., Bachia ssp., Chalcides, L. whitii, Liolaemus multicolor, L. quilmes, L. zullyi, T. merianae, Ameiva ssp., Cnemidophorus ssp. Callisaurus draconoides e outros lagartos.

Estabelecidos os distais do carpo, estas cartilagens alongam-se distalmente a semelhança de barras e formam o arcabouço dos dígitos. No estágio 32 a forma externa dos cinco dígitos é evidenciada por estas condensações G. albogularis (Leal et al., 2010). A referida característica externa é observada em I. iguana iguana porem, durante a condrogênse, o dedo $\mathrm{V}$ se forma antes do dedo I, contrariando os relatos para os demais lagartos, onde todos indicam uma formação tardia para o dedo 5 (Rieppel, 1992a, 1994; Lobo et al., 1995; Abdala et al., 1997; Shapiro, 2002; Federico e Lobo 2006; Hugi et al., 2010). Nestes a sequencia condrogênica é $4>3>2>1>5$ e em I. iguana iguana relatamos $4>3>2>5>1$.

Sobre o dedo V, existem ainda muitas informações dispares acerca de sua representação junto ao arco digital. Classicamente Shubin e Alberch (1986) relataram este como uma nova condensação em testudines baseado no relato de Burke e Alberch (1985).

Burke e Alberch (1985), Shubin e Alberch (1986), Burke e Feduccia (1997), SánchezVillagra et al. (2008), Vieira et al. (2010) não encontraram nenhuma conectividade entre o dedo $\mathrm{V}$ e os demais elementos do arco digital, sugerindo ser este uma nova condensação na formação do autopódio dos Tetrapoda. Contudo, dados publicados para anuros relataram o dedo $\mathrm{V}$ como uma estrutura que possui conectividade dos elementos ulnar e dcV em Neobatrachia (Fabrezi e Barg, 2001) e também testudines (Sanchez-Vilagra et al., 2007a). 
Fabrezi et al. (2007) ainda apresentaram evidências que suportam a conectividade do referido dígito ao arco digital (restrito a um membro e um espécime de L. quilmes no estágio 32).

Também para I. iguana iguana não encontramos qualquer evidência que adicione o dedo V a estrtura do arco digital. Embora o referido dedo apresente sua formação antes do dedo I nesta espécie, sua condensação possui um centro de condrificação distinto não relacionada com o arco digital e portanto corrobora com a maior parte dos demais lagartos (Shubin e Alberch, 1986; Müller e Alberch 1990; Rieppel, 1992; Shapiro, 2002).

Talvez seja pretencioso afirmar que exista um modelo claro para a morfogênese do autopódio dos lagartos. Muitos autores descrevem variações entre a estrutura "padrão", principalmente no que tange a presença dos centrais e intermédio (Renous-Lécuru, 1973; Carroll 1988; Gauthier et al. 1988; Fabrezi et al., 2007). As variações podem ser resultado de diferentes pressões evolutivas desses animais, culminando na apresentação de estruturas distintas para grupos diferentes.

Nos lagartos o carpo é um conservado entre as diferentes linhagens. Existe uma variação numérica para a descrição quantitativa dos ossos do carpo onde Romer (1956), Fabrezi et al. (2007), Russell e Bauer (2008) e Leal et al. (2010) consideram o carpo com 9 ossos, enquanto autores como El-Toubi (1947), Stokely (1950), Renous-Lécuru (1973), Caldwell et al. (1995), Fabrezi et al. (2007) e Fontanarrosa e Abdala (2014) relatam 10 ossos, visto a adição de um pequeno osso na mão de alguns animais C. longicaudus, Heloderma suspectum, E. multicarinata, E. umeces, Agama, Xenosaurus e Carsosaurus.

A morfologia em Sphenodon representa uma condição ancestral em Lepdosauria (Romer, 1956; Carrol 1988; Gauthier, et al. 1988) com um bom desenvolvimento do intermédio entre o ulnar e radial. Em lagartos o intermédio pode ser considerado uma variação interespecífica (Leal et al., 2010). Müller e Alberch (1990) relataram que existe uma clara evidencia de que o radial e o intermédio são de origens distintas, embora nos estágios posteriores estes elementos se fundem em crocodilianos.

Em muitas descrições o desenvolvimento deste elemento intermédio foi observado tal como descrito aqui para I. iguana iguana. Existe uma área de condensação notada na região central do carpo, outrora com certa dificuldade em embriões clareados e corados, de definir incialmente a presença pontual desta estrutura. Provavelmente esta área representa a préformação do central intermédio. Leal et al., (2010) relatam esta característica para $G$. albogularis e afirmam ser um atributo basal em dispsida e Lepdosauromorpha.

Descrições anteriores falharam em tentar caracterizar essa condensação (Shapiro, 2002; Fabrezi et al., 2007). Intermédio esta presente em testudines como três estruturas distintas 
(Burke e Alberch, 1985; Sheil, 2003a, b, Sheil e Greenbaum, 2005), fundido ao radial em crocodilianos e ausente em aves (Hinchliffe e Hecht, 1984; Müller e Alberch, 1990; Burke e Feduccia, 1997; Fabrezi et al., 2007).

Mathuer e Goel (1976) identificaram este em C. versicolor, Anguidae (Renous-Lécuru, 1973), Iguanidae (Avery e Tanner, 1964), Lacertidae (Rieppel, 1992b; Maisano, 2002a), Teiidae (Fischer e Tanner, 1979), Varanidae (Rieppel, 1992c), e Xantusiidae (Maisano, 2002b). Em Mabuya (Shapiro, 2002; Fabrezi et al., 2007) o lateral é pequeno e difícil de separar do ulnar e radial, fato que permite a especulação de que este não corresponde ao intermédio ou pode representar uma condensação transitória tal como apresenta Agama e $C$. versicolor (Holmgren 1933; Mathur e Goel 1976; Fabrezi et al., 2007).

Em I. iguana iguana uma nova condensação na região central do carpo origina duas estruturas, um elemento central e outro intermédio, ocupando a mesma posição descrita em $L$. whitii, C. versicolor, C. ocellatus, G. albogularis e Agama (Hugi et al., 2010; Leal et al., 2010). Shapiro (2002) explicita a formação do intermédio em H. initialis por meio de uma pequena condensação aparece entre a parte distal do rádio e a ulna no estágio 38 , (mesma posição observada em I. iguana iguana no estágio 31).

O intermédio é observado na morfologia adulta ou durante a ontogenia de muitos tetrapodas (Romer, 1956; Renous-Lécuru, 1973). Outrora, visto a dificuldade em estabelecer uma concreta homologia deste elemento, sua evidência em lagartos é ainda incerta (Fabrezi et al., 2007; Leal et al., 2010). Jerez et al. (2009) reportaram um osso na região intermédia do carpo de Gekkonidae e $C$. longicaudus mas preferiram classifica-lo com um sesamóide.

É relatado que em algumas espécies esta condensação se funde ou desaparece durante a ontogenia (Mathur e Goel 1976, Mohammed 1991; Leal et al., 2010), permanecendo nos adultos de H. initialis (Shapiro, 2002), Panaspis breviceos, Gerrhosaurus nigrolineatus (Fabrezi et al., 2007) e Iguana. Shapiro (2002) conclui ainda que o cenário provavelmente indica ser este elemento um sesamóide. Fabrezi et al. (2007) relatam a ausência do elemento intermédio no arcabouço cartilagíneo ou no esqueleto adulto em L. multicolor, L. quilmes, L. zullyi e $T$. merianae e sugerem que, para a maioria dos lagartos, pode ser que ele ocorra em algumas espécies no inicio do desenvolvimento como uma condensação embrionária, mas não persista na forma adulta. Tal afirmação carece de dados adicionais que relacionem, por exemplo, grupos de lagartos onde esta característica é comum aos membros.

De acordo com a reconstrução a partir das caracteristicas ancestrais da posição do elemento intermédio no carpo dos lagartos, quatro morfologias seriam distintas para o grupo (Fontanarrosa e Abdala 2014). A mais comum apresenta um espaço livre entre os elementos 
radial e ulnar com o intermédio na região distal, representando o esboço ancestral (Sphenodon). As três demais apresentam variações da posição do intermédio entre o radial e o ulnar (justaposto, interposto e encaixado). Para I. iguana iguana a morfologia adulta exibe similaridade com Kentropix viridistriga, Holoderma suspectum, Leiosaurus cetamarcensis e Phymaturus ceii. O intermédio apresenta-se articulado entre as faces dos ossos radial e ulnar, em forma de cunha.

Elementos centrais distintos ocorrem em muitos táxons, embora sua homologia seja ainda alvo de inúmeros debates, principalmente associados a presença do elemento intermédio. O central é característico do carpo de Squamata (Renous-Lécuru, 1973). Segundo Shubin e Alberch (1986) e Fabrezi et al. (2007) se forma por meio da bifurcação do intermédio. Não observamos qualquer conectividade entre o central e o intermédio em $I$. iguana iguana mas como relatado para outros lagartos, ambos estes elementos surgem de uma condensação independente.

Historicamente foi atribuído ao carpo dos lagartos um elemento central lateral e outro medial (Maisano 2002a, b). Para Renous-Lécure (1973) o central medial é nominado dcI. Dados da morfogenese explicitados por Fabrezi et al. (2007) permitem concluir que este tratase de um elemento do arco digital.

No carpo de I. iguana iguana duas condensações surgem na região central do autopódio, o intermédio e um central. A evidencia de um elemento central lateral e outro central medial não foi observada para esta espécie, diferindo do descrito para G. albogularis e Mabuya sp. que possuem ambos os centrais, sendo o central medial uma condensação independente (Leal et al., 2010).

Embora existam algumas variações na forma adulta, bem como nas relações de homologia estabelecidas pelos autores, normalmente são descritas duas condensações na parte proximal do mcI. Holmgren (1933) descreveu, além do intermédio, duas condensações em Agama e Leal et al. (2010) relataram algo semelhante em G. albogularis sendo o dcI, que funde com o mcI e o central.

Em B. bicolor está presente em alguns espécimes um central cartilagíneo, podendo se fundir com o radial ossificado (Jerez e Tarazona, 2009). No estágio 32, ocorre uma condensação prévia dos elementos centrais em G. albogularis, que provavelmente representa a fusão do central lateral e intermédio (Leal et al., 2010). Um central distinto está presente no carpo cartilagíneo de Mabuya ssp. (Leal et al., 2010). Nenhuma fusão entre estes elementos ocorreu em I. iguana iguana. Ambas as condensações estão presentes como elementos ossificados nos adultos. 
Esta seria a melhor hipótese para explicar o que ocorre em I. iguana iguana. Observamos, além do intermédio, a condensação de duas cartilagens na base do mcI. A primeira segmenta-se do arco digital, alonga-se e forma o dígito I. A segunda origina-se de uma condensação independente. Com base nas informações de Carroll (1988) podemos concluir que I. iguana iguana possui em dcI e um central corroborando os demais autores. Vale ressaltar que o dcI em I. iguana iguana é apenas cartilagíneo e não forma uma estrutura ossificada no adulto.

Ambas as cartilagens não aparecem simultaneamente embora sejam observadas no mesmo estágio (Leal et al., 2010). Em uma investigação com foco na homologia do carpo de lagartos, Fabrezi et al. (2007) são categóricos ao afirmar que existe apenas um central no carpo de lagartos, o segundo elemento (central medial) seria o dcI. Os dados relacionados aqui para I. iguana iguana não nos permite concordar com tal afirmação. Esta discussão reporta a morfologia do último antescessor comum dos lagartos que possuia dois carpais proximais, um central, um intermédio, um pisiforme e cinco distais (Romer, 1956; Mathur e Goel 1976; Rieppel, 1992b).

Após a diferenciação das estruturas do arco digital em lagartos podemos observar a existência de cinco dígitos e cinco elementos distais, embora o dcI seja nominado central medial por alguns autores (Gauthier et al., 1988; Carroll e Currie, 1991; Maisano, 2002a, b). Este elemento é certamente parte do arco digital (Fabrezi et al., 2007) tal como relatado em $I$. iguana iguana, visto sua segmentação a partir da cartilagem do dcII. Nos embriões analisados observamos que deste elemento segmenta-se a cartilagem do mcI, dando origem a uma estrutura distinta que posteriormente funde-se ao referido metacarpo.

Diversos autores relataram semelhante característica no desenvolvimento do dcI em outros lagartos. Em G. albogularis (Leal et al., 2010) seu precursor cartilagíneo se desenvolve na região distal do autopódio e no estágio posterior funde-se a estrutura da cartilagem do mcI. A mesma característica foi relatada para Mabuya ssp. (Leal et al., 2010), Agama (Holmgren, 1933), C. chalcides (Young et al., 2009), C. versicolor (Mathur e Goel, 1976), T. marianae e Liolaemus ssp. (Fabrezi et al., 2007). O dcI não foi descrito em Callisaurus draconoides (Maisano, 2002a).

A existência dos elementos central e dcI é ainda controversa. Embora muitos relatos descrevem a presença de um dcI fundido ao mcI e um central, a homologia entre estes é alvo de discussões. Esta característica pode ser generalizada para outros squamatas (Carroll 1988), embora, comparado com o arranjo basal, alguns autores consideram o medial ausente em lagartos (Romer, 1956; Renous-Lécuru, 1973). 
Nenhuma fusão adicional ocorre no carpo de I. iguana iguana (exceto entre o dcI e mcI). Shapiro (2002) descreveu uma fusão entre o dc4 e dc5 em $H$. initialis e $H$. quadrilineata. Cada elemento surge com uma condensação única e depois se funde, embora se ossifiquem de maneira distinta. Estas espécies exibem uma grande redução nos elementos distais dos membros anteriores e portanto tal característica é certamente resultado desse processo, justificando a ausência de fusões adicionais em iguana, visto que a referida espécie não apresenta redução dos dígitos.

Em diversas espécies ocorre redução dos elementos que formam os dígitos ou o membro. Tais processos envolvem genes que regulam a expressão de falanges, metacarpos e carpos em mecanismos de redução principalmente por fusão entre os precursores cartilagíneos (Romer e Parsons, 1985; Shapiro, 2002; Shapiro et al., 2003; Maxwell e Larsson, 2009). Para Burke e Alberch (1985) os elementos que se formam mais tardiamente são os mais susceptíveis a redução durante a evolução, embora as mudanças progressivas ao longo da evolução não sejam completamente compreendidas.

É provável que os Squamata retém completamente os elementos do carpo presentes em outros lepdosauromorpha, ao menos como elementos transitórios durante a ontogenia. $\mathrm{O}$ aspecto geral do autopódio destes animais é bastante especializado e portanto exibe modificações conspícuas em sua arquitetura e formação, podendo refletir particularidades oriundas de milhares de anos de adaptação.

Alguns ossos sesamóides podem ocorrer no carpo de lagartos. Segundo Renous-Lécuru (1973), o pisiforme é um elemento constante nos Squamata. Shapiro (2002) e Fabrezi et al., (2007) completam que ele é considerado um sesamóide pois não se forma do eixo primário, estando associado aos tendões dos músculos adjacentes. Outros elementos foram descritos mas o pisiforme é altamente conservado na estrutura do carpo dos repteis (Carroll e Currie 1991). Em Bachia existe um segundo sesamóide denominado sesamóide palmar, que permanece cartilagíneo em neonatos, tal como em outros lagartos (Maisano, 2002a; Jerez, 2007). O pisiforme não existe conexão com qualquer outro elemento do autopodio.

Em I. iguana iguana o único sesamóide que se desenvolve no período embrionário e também descrito no esqueleto adulto é o pisiforme. Embora esta espécie não apresente redução digital, a presença de poucos sesamóides é uma característica associada esta particularidade nos lagartos, tal como Chalcides (Jerez, 2007). Maisano (2002b) completa que a constância de alguns sesamóides pode ser interpretada como um possível sinapomorfia para o grupos. A presença destes elementos pode estar associada a diversos outros fatores tais 
como o aporte biomecânico, fatores ambientais, genéticos e ontogênicos específicos ligados ao desenvolvimento ou a história epigenética (Vickaryous e Olson, 2007).

Nesta e em outras investigações as disparidades entre os padrões de condrificação e ossificação são claros (Rieppel 1993a; Maisano 2002b; Sheil e Greenbaum 2005, Fabrezi et al., 2007, 2009; Sánchez-Vilagra et al., 2007; Hugi et al., 2010; Leal et al., 2010; Vieira et al., 2010). Os dados relacionados apontam que a ossificação em lagartos exibe uma grande variação, mas no geral mantém constante os elementos formados durante a condensão das cartilagens.

A sequência de ossificação em vertebrados em sido discutida extensivamente durantes as últimas décadas (Keller, 1946; Mohammed, 1991; Rieppel, 1992, 1993, 1994; Caldwell, 1994, 1997; Abdala et al.,1997; Haas, 1999; Maisano, 2002a, b; Shapiro, 2002; Fabrezi et al., 2007; Fröbisch, 2008; Werneburg et al., 2009; Hugi et al., 2010; Leal et al., 2010; Vieira et al., 2010; Lima et al., 2012). Investigações diversas tem se preocupado em esclarecer os eventos de formação do esqueleto. Fröbisch (2008) resumiu os dados de ossificação de várias espécies e conclui que os Tetrapoda exibem uma plasticidade geral no desenvolvimento dos membros em comparação com os lagartos de hábitos terrestres sem redução de membros. Segundo este estudo, a sequência ontogênica destes é sempre próximo-distal (Rieppel, 1992, 1993a, 1993b, 1994a, 1994b; Fröbisch, 2008; Hugi et al., 2010).

Maisano (2002 a, b) contradiz tal afirmação quando relata que a sequência de ossificação não segue o modelo do eixo proximo-distal, o eixo primário e o arco digital tal como relatado nas cartilagens. A dominância durante a formação óssea varia entre os dedos III e IV para os lagartos e indica uma formação tardia para o dedo V (Rieppel 1992, 1994; Lobo et al., 1995; Abdala et al., 1997; Shapiro, 2002; Federico e Lobo 2006; Fabrezi et al., 2007, 2009; Hugi et al., 2010), inclusive para I. iguana iguana. Em L. whitii (Hugi et al., 2010), L. agilis exigua (Rieppel, 1994), Hemiergis ssp. (Shapiro 2002), C. ocellatus (Mohammed, 1991), T. marianae (Federico e Lobo, 2006) existe uma dominância do dedo IV e para Z. vivipara (Rieppel 1992) e G.oceanica (Rieppel 1994) do dedo III tal como apresentado por I. iguana iguana.

Embora exista uma dominância compartilhada entre o dígito IV (parte integrante do eixo primário) e o dígito III, a sequência de formação óssea foi completamente distinta da formação condrogênica em I. iguana iguana e na maioria dos lagartos (Rieppel 1992a, 1994; Lobo et al., 1995; Abdala et al., 1997; Shapiro, 2002; Federico e Lobo 2006; Fabrezi et al., 2007, 2009; Hugi et al., 2010). Para os metacarpos, em L. agilis exigua (Rieppel, 1994) a sequência foi $\operatorname{mc} 3>\mathrm{mc} 4>\mathrm{mc} 2>\mathrm{mc} 1>\mathrm{mc} 5, \quad Z$. vivipara (Rieppel, 1992) 
mc3>mc4>mc2>mc1>mc5, para L. whitii (Hugi et al., 2010) é comum encontrar variação entre $\mathrm{mc} 3>\mathrm{mc} 4>\mathrm{mc} 2>\mathrm{mc} 1>\mathrm{mc5}$ ou $\mathrm{mc} 4>\mathrm{mc} 3>\mathrm{mc} 2>\mathrm{mc} 1>\mathrm{mc} 5$, em Bachia (Jerez e Tarazona 2009), mc3>mc4>mc2>mc1>mc5, similar a C. draconoides (Maisano, 2002a; Jerez, 2007) e em I. iguana iguana $\mathrm{mc} 3>\mathrm{mc} 4>\mathrm{mc} 2>\mathrm{mc} 1>\mathrm{mc} 5$.

Em geral, os padrões são correspondentes entre os lagartos à sequência primitiva (mc4>mc3>mc2>mc1>mc5) (Müller 1991) haja vista que a ossificação em Lacertilia exibe um alto grau de conservação (Caldwell, 1994), diferente de outros grupos de répteis que possuem conspícuas diferenças (Vieira et al., 2010). A dominância do dedo 3 para os lagartos é evidente nos relatos acima. Esta característica ocorre também na ossificação em outros animais (Alligator, Chelydra Rieppel, 1993a, b), confirmando a dissociação dos eventos de condrogênese e osteogênese (Rieppel, 1994), bem como a manutenção de um padrão geral para os lagartos (Caldwell, 1994).

Segundo Fabrezi et al. (2007) a ossificação ocorre somente quando as cartilagens estão completamente diferenciadas. Em I. iguana iguana a ossificação teve início somente após a completa formação do arcabouço cartilagíneo, corroborando Hinchliffe e Johnson (1983) e Thorogood (1983). Estes autores reforçam que, por tratarem-se de eventos distintos, condrogênese e osteogênese podem acontecer simultaneamente mas devem ser interpretados como eventos independentes.

A região do autopodio não apresenta muitas variações no que diz respeito a dominância, mas mostra algumas diferenças em sua composição. Alguns elementos que se formam durante a condrogênse podem se fundir (Romer, 1956; Shubin e Alberch 1986; Mathur e Goel 1976), mantendo os centros de ossificação (Romer eParsons 1985; Shapiro, 2002; Maxwell e Larsson 2009).

Como supracitado, apenas a fusão entre o dcI e o mcI ocorre em I. iguana iguana. Müller (1991) dentre outros concordam que a heterocronia representa um fator importante para o entendimento de muitas das alterações que ocorrem durante a embriogenese do esqueleto e tais modificações no padrão de condrogênse são de conspícua importância no entendimento de aspectos filogenéticos.

A ossificação do carpo entre os lagartos ocorre tardiamente em relação aos demais elementos dos membros. Em Hemiergis ocorre somente no período pós natal (Shapiro, 2002). Outras espécies apresentam poucos elementos ossificados no período embrionário. No estágio de eclosão o ulnar e o dcIV possuem centros de ossificação desenvolvidos, e o dcIII inicia sua ossificação neste estágio em L. agilis exigua (Rieppel, 1994). O primeiro centro ossificado surge tardiamente no grande elemento central, indicado como dcIV em Chamaleo (Rieppel, 
1993). Em L. whitii Hugi et al. (2010) relataram apenas o radial e o dc4 se ossificando no periodo embrionário.

Para as espécies C. draconoides, U. stansburiana, e L. scapularis é relatada a mesma sequência. Os ossos ulnar, radial e os dcII a V ossificam-se no mesmo estágio. Os demais elementos apenas no período pós eclosão. Em C. pubisulcus o ulnar e o dcIV no mesmo estágio e no seguinte o radial e dcIII.

Dentre estas espécies, apenas em U. stansburiana e Z. vivipara o pisiforme não foi o último elemento a se formar no carpo (Rieppel 1992, 1993, 1994; Maisano, 2002a; Shapiro, 2002; Fabrezi et al., 2007). Visto a ossificação do pisiforme no período pós eclosão em $I$. iguana iguana, não podemos confirmar esta informação para a espécie embora, acreditemos ser este o padrão para a espécie visto que a sequência de ossificação dos demais elementos é bastante similar (ulnar e o dcIV no estágio 43; dcIII e dcV, seguido pelo radial estágio 44), corroborando o padrão conservativo deste grupo.

\section{Membro pelvino}

A contribuição dos vários elementos e sua identidade para a formação dos ossos do pé é controversa. Nas últimas décadas investigações diversas tiveram foco em tentar subsidiar e esclarecer este tópico. O tarso de Squamata é composto por poucas estruturas sendo um elemento proximal (astragalus+calcâneo) e dois distais (distal do tarso 3 -dtIII- e distal do tarso 4 -dtIV) (Camp 1923; Romer, 1956; Robinson 1975; Mohammed 1988; Rieppel \& Grande 2007; Conrad 2008; Russel e Bauer, 2008), tal como relatado para I. iguana iguana. Outrora, em C. versicolor Mathur e Goel (1976) descreveram três distais (dtI).

Ossos adicionais e distintos foram descritos em alguns adultos, interpretados como distais do tarso ou sesamóides (Russel e Bauer, 2008; Hugi et al., 2010), embora nos adultos de I. iguana iguana sesamóides tenham sido relatados apenas nas mãos.

O inicio da condrificação ocorre no estágio 29 em G. albogularis (Leal et al., 2010) e $I$. iguana iguana, sendo relativamente cedo nos lagartos. Nesta fase os elementos do tarso são ainda indiferenciados na porção distal do membro visto a presença de uma área de condensação. O eixo primário já se estabeleceu com sua formação partindo do fêmur e seguindo para a tíbia e a fibula. Nos estágios seguintes o fibular (calcâneo) e dt IV e mtIV segmentam-se do eixo primário (Holmgren, 1933; Schaeffer, 1941; Mathur e Goel, 1976; Burke e Alberch, 1985; Shubin e Alberch, 1986; Shapiro 2002).

Neste momento, o membro apresenta parte distal bem desenvolvida que exibe uma 
condensação na região central do tarso. Em I. iguana iguana esta região ocupa a área entre a segmentação do fibular e a borda lateral do pé. Informação que corrobora Leal et al. (2010) que relatam no centro da estrutura a existência de extensa área corada que dará origem a várias condensações. Segundo os autores estas se fundirão para formar o astragalus. A homologia desta estrutura tem sido debatida, mas é consenso que esta trata-se de uma fusão de condensações da região intermédia do tarso (Holmgren, 1933; Mathur e Goel, 1976; Burke e Alberch, 1985; Shubin e Alberch, 1986; Rieppel, 1993c; Abdala et al., 1997; Shapiro 2002; O'Keefe et al., 2006; Fabrezi et al., 2007, 2009, Leal et al., 2010; Hugi et al., 2012).

Após a segmentação do dt4 e mt4, os digitos III, IV e V são observados em I. iguana iguana e G. albogularis (Leal et al., 2010). O dígito III tem clara segmentação do dt3. Em Mabuya (Fabrezi et al., 2007) o dt2 segmenta-se do mt2, mas em I. iguana iguana esta segmentação não foi completa, permanecendo o dt2 fundido ao mt2.

No estágio 31 em G. albogularis (Leal et al., 2010) a região central exibe uma condensação que sugere a fusão do central e intermédio. Condensação similar foi observada em I. iguana iguana. Em Mabuya, além do fibular, duas condensações adicionais darão origem ao astragalus: tibial e uma segunda preaxial ao fibular (possivelmente a fusão entre central 4 e intermédio). Posteriomente o central tarso II e III são incluidos neste. Em Liolaemus ssp. essa cartilagem e o fibular formam o grande proximal do tarso como encontrado em Amniota basais (Romer, 1956).

Dados fósseis sugerem que o astragalus é formado pela fusão de numerosos elementos como tibial, intermédio, central III e central IV (O'Keefe et al., 2006), contudo a contribuição do distal central e tibial permanece ainda incerta (Holmgren, 1933; Mathur e Goel, 1976; Mohammed, 1991; Fabrezi et al., 2007; Leal et al., 2010). Devido a característica do processo de condrificação, com a formação de centros de condensação fica fácil observar o desenvolvimento dos elementos, porém, relacionar sua homologia depende de mais informações.

Embora seja claro que o astragalus representa um compilado de vários outros elementos do tarso (Berman e Henrici, 2003; O’Keefe et al., 2006), Rieppel (1993c) sugeriu ser esta uma nova estrutura, visto que em seu relato é formada por um único centro de ossificação. Ele sugere que os vários elementos que supostamente formam o astragalus cartilagíneo não são homólogos ao indivíduo basal. Assim, a fusão dos elementos e a formação de apenas um centro de ossificação justifica sua teoria (Romer, 1956, Carrol, 1998). Dados fósseis refutam esta teoria e evidenciam a fusão dos elementos do tarso para formação do astragalus (Berman e Henrici, 2003; O’Keefe et al., 2006), tal como ficou conspícuo nos relatos acima e 
adicionados os dados encontrados em I. iguana iguana.

Fabrezi et al. (2009) relataram que o fibular e o intermédio-central são as cartilagens que formam o astragalus. Esses dados são similares aos descritos para outros répteis (Müller, 1991) embora em testudines exista mais elementos centrais (Burke e Alberch, 1985; Sheil, 2003). Romer (1956) relatou ainda que este seria formado apenas por um tibial ou um intermédio, embora Schaeffer (1941) tenha reportado a perda do elemento tibial em répteis. Mohammed (1991) descreveu um terceiro elemento em C. ocellatus como distal central, não foi obervado em L. whitii ou I. iguana iguana.

Visto as incertezas no que diz respeito a homologia e as condensações que formam o astragalus, não conseguimos determinar com clareza quais elementos formam o astragalus de I. iguana iguana. A partir dos embriões analisados podemos confirmar que dois grandes precursores (provavelmente um intermédio e um central) se fundem para formar o astragalus, tal como relatado para a maioria dos lagartos (Fabrezi et al., 2007; Hugi et al., 2010; Leal et al., 2010).

Outra característica que parece conservada para os lagartos é a fusão do astragalus ao calcâneo (fibular). Em todas as espécies relacionadas nesta investigação a fusão ocorre após o completo estabelecimento da cartilagem do astragalus, formando um amplo elemento denominado proximal do tarso (Mathur e Goel, 1976; Burke e Alberch, 1985; Shubin e Alberch, 1986; Rieppel, 1992a, b, 1994a, b; Holmgren, 1933; Shapiro 2002; Fabrezi et al., 2007, Leal et al., 2010; Lobo et al., 2010; Hugi et al., 2012).

Garthia gaudichaudii, Hemidactylus mabouia, e Phyllopezus pollicaris apresentam um osso adicional entre o mt1 e mt2, sendo considerado o dt1 (Mathur e Goel, 1976; Mohammed, 1988) ou a fusão dos dt1 e dt2 (Holmgren, 1933). O anterior distal do tarso e dt3 estão presentem em vários lagartos (Stephenson, 1960; Mathur e Goel, 1976; Mohammed, 1988; Bauer, 1990). Fabrezi et al. (2007) chamaram este elemento de distal do tarso anterior, visto a carência de dados embriológicos para confirmar o exposto por Holmgren (1933). Nenhuma segmentação ou condensação adicional foi relatada em I. iguana iguana. O padrão de formação para os ossos do tarso desta espécie foi congruente com de outros lagartos.

A segmentação do arco digital em lagartos mostra sequência e conectividade que corrobora a descrição de Shubin e Alberch (1986). Os elementos do eixo primário são conservados inclusive nos taxon com redução de membros (Shapiro, 2003). A sequência para a condensação dos digitos pode variar um pouco, mas a dominância do dedo IV e a tardia formação do dedo V é conspícuo para os lagartos (Mohammed 1991; Rieppel, 1992a, b, 1994a, b; Lobo et al. 1995; Abdala et al. 1997; Shapiro 2002; Federico e Lobo 2006; Fabrezi 
et al., 2007; Hugi et al., 2010; Leal et al., 2010; Lobo et al., 2010).

As investigações relatam a ossificação do mtV tardia em lagartos (Rieppel, 1992a, 1994; Lobo et al., 1995; Abdala et al., 1997; Shapiro 2002; Federico e Lobo, 2006). Em L. whitii (Hugi et al., 2010), L. agilis exigua (Rieppel 1994b), T. merianae (Federico e Lobo 2006) existe predominancia na ossificação do digito IV antes do III nos pés. Em Z. vivipara (Rieppel, 1992b) e G.oceanica (Rieppel 1994a), digito III precede o digito IV em pé e mão. O gradiente de ossificação de todos os Hemiergis spp. (Shapiro, 2002) como em C. ocellatus (Mohammed, 1991) reflete a teoria de dominância do dígito IV, tal como ocorrem em $I$. iguana iguana.

O astragalus é o primeiro elemento do tarso a se ossificar (Rieppel, 1992a, b, 1993b, 1994a, b; Mohammed et al., 1995; Lobo et al., 1995; Abdala et al., 1997; Maisano 2002 a, b; Shapiro, 2002; Federico e Lobo 2006; Hugi et al., 2010, Leal et al., 2010). O padrão normalmente ocorre: astragalus $>$ fibular $>\mathrm{dtIV}>\mathrm{dtIII}$ e para a maioria dos lagartos este processo ocorre após a eclosão (Shapiro, 2002). Lobo et al. (2010) relataram para Liolaemus a ossificação tardia do dtIV. Em Z. vivipara Rippel (1992) relatou a ossificação do dt4 antes do fibular.

Em I. iguana iguana, o centro de ossificação do astragalus está presente nos embriões corados com alizaria no estágio 42. É possível observar o início da formação de dois centros de ossificação distintos para o proximal do tarso. Tal informação corrobora Mohammed (1988) e Fabrezi et al. (2007) que destacaram a existencia dos centros de ossificação correspondentes ao fibular e o astragalus. Tal característica é comum em lagartos com exceção de Chamaleo (Rieppel 1993b) onde apenas um centro ossificado está presente.

Embora exista um grande dtIV e um menor dtIII, a presença de um distal tarsal anterior pode ser reportada em Gekkonids (Fabrezi et al., 2007) e G. albogularis. Pode ser o dtI ou dtII, mas em G. albogularis e Mabuya o dtII esta presente mas se funde ao mtII e o dtI não segmenta-se do mtI. Contudo aparece entre mtI e o dtII um menisco cartilagíneo, assim definimos a existência de um sesamóide (Leal et al., 2010).

O dtV funde ao mtV (Fabrezi et al., 2007). Em Sphenodon (Howes e Swinnerton, 1901) não reportam o dtV mas ele provavelmente se funde ao mt5. Romer (1956) inferiu que a ausência do dt5 seria provavelmente resultado de sua fusão com o mtV ou o dtIV. Posteriormente Mohammed (1988) conclui para C. ocellatus que a presença do $\mathrm{mtV}$ não é devido a fusão com o dtV, e sim resultado de um provável ajuste anatômico na parte distal do membro. A relação entre o mtV e o dtV foi (e talvez ainda seja) motivo de debate. Está presente na maioria dos répteis, embora sua homologia e formação seja atualmente pontuada 
como distinta entre alguns grupos.

Nos lepdosauromorpha e Archosauromorpha e em outros répteis primitivos é considerado a última sinapomorfia dos Sauria e diapsida. A primeira descrição pormenorizada foi realizada por Robinson (1975) que relatou a presença de um $\mathrm{mtV}$ similar aos demais metatarsos que se articula com um dtV ou, para a maioria dos lagartos descritos, representa um elemento diferenciado com expansão medial que articula-se com o mtIV, estando o dtV sempre ausente.

Podemos analisar este cenário como uma modificação da morfologia do dtV. Em testudines é consenso que o dtV e o mtV estão presentes durante a ontogenia e na maioria dos adultos (Burke e Alberch, 1985; Sheil, 2003, 2005; Sánchez-Villagra et al., 2007a, b; Fabrezi et al., 2009). Estudos recentes mostram que o $\mathrm{mtV}$ é modificado em Lepdosauria e Archosauria (Müller; Alberch, 1990; Fabrezi et al., 2007). Não existem dados até o momento que evidenciem a formação condrogênica do dtV em qualquer espécie de lagarto.

\section{CONSIDERAÇÕES FINAIS}

Embora tenham sido averiguadas algumas diferenças na cronologia, a sequência de formação das estruturas durante os estágios de desenvolvimento embrionário de Iguana iguana iguana é similar a de outros lagartos. Existem 44 estágios de desenvolvimento para $I$. iguana iguana dos quais 27 ocorrem antes da oviposição e os demais (28 ao 44) no período pós-oviposição.

O desenvolvimento dos arcos faríngeos, dos membros e das estruturas crânio-faciais, a formação das vesículas do sistema nervoso e dos somitos são elementos determinantes nos estágios iniciais. A formação de escamas, pigmentação, ossificação, pálpebras, dente do ovo e o incremento corporal são características fundamentais que marcam o desenvolvimento tardio, permitindo a identificação dos estágios finais.

Iguana possui o desenvolvimento do crânio de maneira similar aos demais lagartos. Os primeiros elementos a se ossificar são o pterigóide, maxila, palatino e ossos dérmicos da mandíbula. Tal característica é comum aos vertebrados visto o atendimento de necessidades básicas durante a formação do arcabouço esquelético do crânio. Ossos relacionados com a estrutura do assoalho e teto craniano, bem como aqueles de origem endocondral, se formam tardiamente. A presença da fontanela craniana no embrião é uma característica dos membros do grupo Iguania, tal como a redução do osso lacrimal, a fusão dos ossos opstótico e 
excoccipital, formando o otoccipital e a presença de um frontal ímpar, embora formado por duas placas distintas no embrião.

Está ausente no adulto e durante a ontogenia o osso quadradojugal. O osso jugal apresenta redução de tamanho. O osso pós-frontal está presente como uma estrutura independente durante a formação tal como descrito no adulto, posicionado rostralmente ao osso frontal, na margem dorsal da órbita.

As vértebras e os ossos dos cíngulos pelvino e torácico se formam em um padrão conservativo para os lagartos. $\mathrm{O}$ gradiente de ossificação das vértebras é crânio-caudal. O arco vertebral, centro vertebral e costelas apresentam centros de condrificação e ossificação distintos para cada vértebra. As vértebras sacrais são duas e em I. iguana iguana são independentes. Anexo a estas existe um par de costelas sacrais com origem endocondral e ossificação por meio de um centro independente do arco e corpo vertebral, fundindo-se a este durante a ontogenia.

Nos cíngulos a sequência de ossificação é padrão segundo o reportado para os demais lagartos e répteis e não existe redução neste segmento.

A formação dos membros segue o padrão geral para os Tetrapoda com a formação do eixo primário, o arco digital e com presença de condensações independentes que dão origem a elementos no esqueleto adulto.

No membro torácico o dedo 4 é predominante na condrogênese. São formados elementos distais que dão origem aos dígitos. No dígito I o elemento distal não se segmenta do metacarpo. São formadas duas condensações independentes do arco digital no carpo, o central e o intermédio.

No membro pelvino a relação de homologia do elemento astragalus é ainda incerta. Foi possível observar a formação de uma grande área de condensação no autopodio, identificada como intermédio que se funde ao fibular e forma o proximal do tarso. A presença de elementos adicionais para formação deste não foram relatados. Existem 2 elementos distais no tarso de Iguana. Os demais distais não se segmentam da cartilagem dos respectivos metatarsos.

Como nos demais répteis o desenvolvimento do dedo $\mathrm{V}$ é atrasado em relação aos demais, sendo este resultado provável de uma condensação independente do arco digital.

São necessários ainda estudos adicionais para completa elucidação da homologia dos elementos do carpo e tarso, principalmente. Embora algumas destas estruturas sejam bem relatadas, as discussões a respeito da presença, ontogenia, morfologia e homologia do 
intermédio, central e distal do carpo I na mão, bem como do astragalus, metatarso $\mathrm{V}$ e distais do tarso no pé carecem de mais dados para elaboração de conceitos mais claros. 


\title{
07 ANEXOS
}

\author{
Anexo I \\ unesp \\ UNIVERSIDADE ESTADUAL PAULISTA \\ "JÚLIO DE MESQUITA FILHO" \\ DECISÃO CEUA No ${ }^{003 / 2009}$ \\ Protocolo $\mathrm{n}^{0}$ : 4173 de 1\%07/09 Data de Registro CEUA: 02/07/09 \\ Projeto de Pesquisa: "Excreção de nitrogênio em embrião de iguana Iguana iguana \\ (Reptilia; Lacertilia)"
}

Pesquisador Responsável: Prof. Dr. Augusto Shinya Abe

Orientando(a): Marina Rincon Sartori

Colaboradores: -.-

\begin{tabular}{l|l}
\hline & ( ) TCC \\
Objetivo & (X) Mestrado \\
Acadêmico: & ( ) Doutorado \\
\hline
\end{tabular}

A Comissão de Ética no Uso de Animal - CEUA do Instituto de Biociências da UNESP - Campus de Rio Claro, em sua $1^{\text {a }}$ reunião extraordinária, realizada em 14/12/ 2009,

\begin{tabular}{|c|l|}
\hline ( ) & $\begin{array}{l}\text { Aprovou o Projeto de Pesquisa acima citado, ratificando o parecer emitido } \\
\text { pelo relator. }\end{array}$ \\
\hline ( ) & $\begin{array}{l}\text { Desde que atendidas as pendências apontadas na reunião (vide anexo), } \\
\text { aprova o Projeto de Pesquisa acima citado (prazo máximo de } 30 \text { dias). }\end{array}$ \\
\hline ( x $)$ & $\begin{array}{l}\text { Referendou o Projeto de Pesquisa acima citado, ratificando o parecer } \\
\text { emitido pelo relator. }\end{array}$ \\
\hline ( ) & $\begin{array}{l}\text { Aprovou retornar ao interessado para atendimento das pendências } \\
\text { encontradas (prazo máximo de } 30 \text { dias). }\end{array}$ \\
\hline ( ) & Não Aprovou. \\
\hline ( ) & Retirou, devido à permanência das pendências. \\
\hline
\end{tabular}

\begin{tabular}{|c|}
\hline Rio Claro, 15 de dezembro de 2009 \\
Prof. Dr. Cello Fernando Baptista Haddad \\
Coordenador do CEUA
\end{tabular}


Anexo I

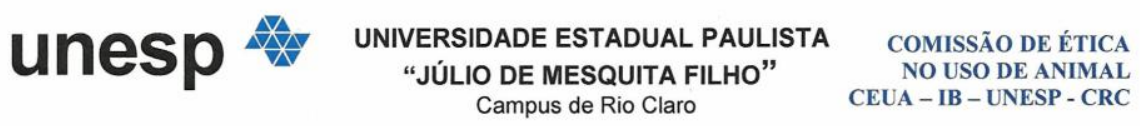

\begin{tabular}{|l|}
\hline Protocolo $n^{0}: 4173\left(1^{\circ}-07-09\right)$ \\
\hline Data Registro CEP: 02-07-2009 \\
\hline
\end{tabular}

Rio Claro, 03 de setembro de 2009.

Ofício CEUA 002/2009

Prezado Senhor,

Aprovo "ad referendum" da Comissão de Ética no Uso de Animal, UNESP, Campus de Rio Claro (CEUA-IB-UNESP), o projeto de pesquisa intitulado "Excreção de nitrogênio em embrião de iguana Iguana iguana (Reptilia; Lacertilia)", sob sua responsabilidade, tendo como orientanda Marina Rincon Sartori.

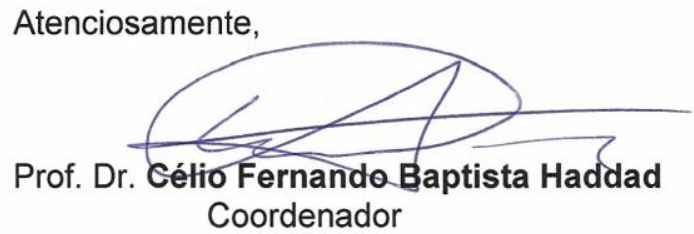

IImo. Sr.

Prof. Dr. AUGUSTO SHINYA ABE

DD. Docente do Departamento de Zoologia - I.B.

UNESP - CRC 
Anexo II

\section{UNIVERSIDADE ESTADUAL PAULISTA "JÚLIO DE MESQUITA FILHO" \\ Instituto de Biociências - Campus de Rio Claro \\ Departamento de Zoologia}

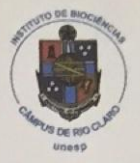

Rio Claro, 15 de junho de 2012

\section{DECLARAÇÃo}

Com a presente, estamos entregando a Fabiano Campos Lima, docente da Universidade Federal de Goiás, Campus de Jataí, a título de empréstimo, 118 embriões de iguana (Iguana iguana) em diferentes estágios de desenvolvimento. Os embriões foram objeto de estudo da dissertação de mestrado de Marina Sartori Rincon e servirão para pesquisas complementares a serem desenvolvidas pelo portador.

Atenciosamente,

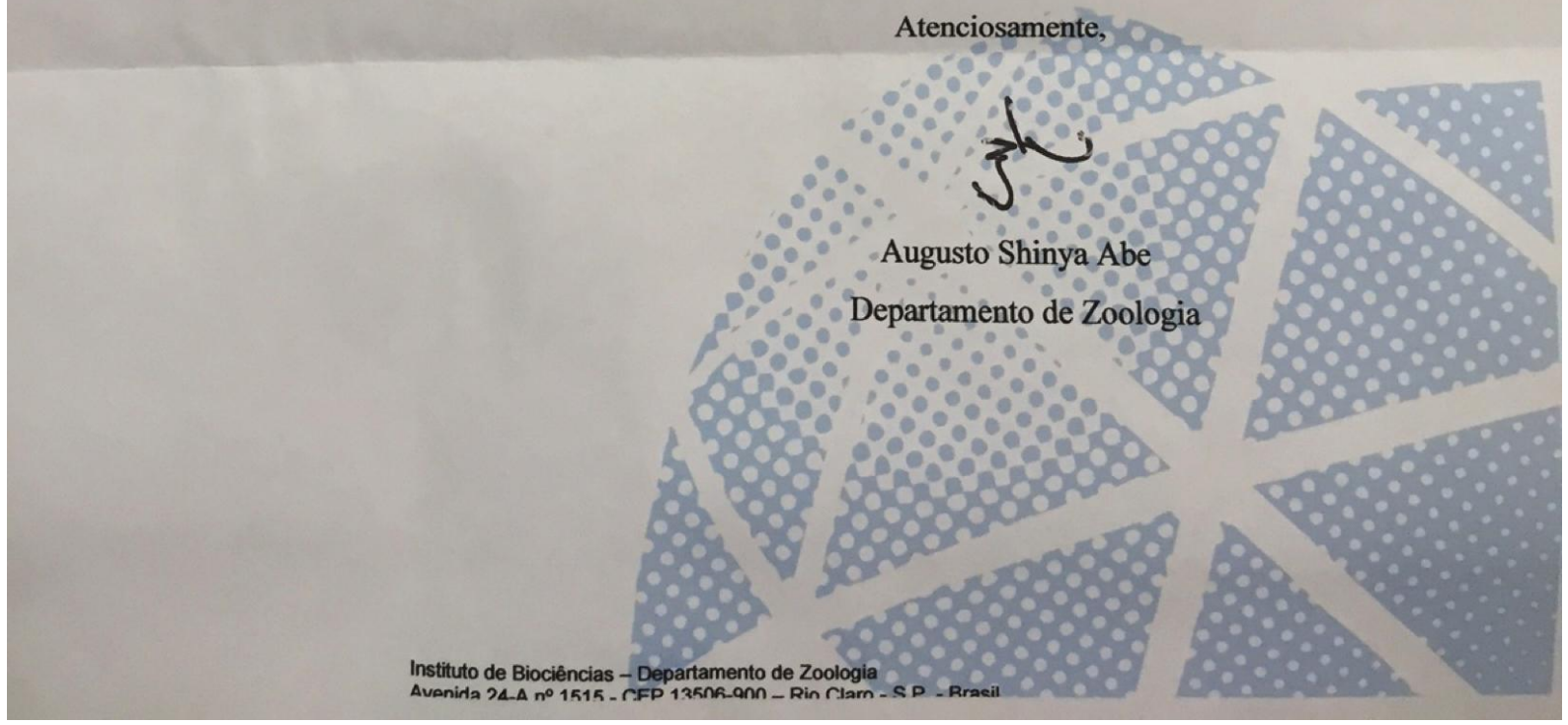


Anexo III

Universidade Federal de Uberlândia

Pró-Reitoria de Pesquisa e Pós-Graduação

Comissão da Ética na Utilização de Animais (CEUA)

Avenida João Naves de Ávila, no. 2160 - Bloco A, sala 224 - Campus Santa Mônica Uberlândia-MG -

CEP 38400-089 - FONE/FAX (34) 3239-4131; e-mail:ceua@propp.ufu.br;

www.comissoes.propp.ufu.br

\section{ANÁLISE FINAL № 106/12 DA COMISSÃO DE ÉTICA NA UTILIZAÇÃO DE ANIMAIS PARA O PROTOCOLO REGISTRO CEUA/UFU 070/12}

Projeto Pesquisa: "Ontogenia de Iguana iguana: Estágios embrionários e desenvolvimento do esqueleto"

Pesquisador Responsável: Prof. Dr. André Luiz Quagliatto Santos

O protocolo apresenta as seguintes pendências:

- Não cabe a esta CEUA aprovar um protocolo já aprovado em outra instituição e com as amostras já obtidas. Caso necessite de uma comprovação para futura publicação, essa comissão sugere que o pesquisador utilize o protocolo de aprovação emitido pela CEUA UNESP

Uberlândia, 10 de Outubro de 2012.

Prof. Dr. Jonas Dantas Batista

Coordenador Pro Tempore da CEUA/UFU 


\title{
Anexo IV
}

\section{Osteologia do neurocrânio de Iguana iguana iguana (Squamata: Iguanidae) ${ }^{1}$}

\author{
Fabiano C. Lima ${ }^{2 *}$, Kleber F. Pereira ${ }^{2}$, Augusto S. Abe ${ }^{3}$ e Antonio Sebben ${ }^{4}$
}

\begin{abstract}
Lima F.C., Pereira K.F., Abe A.S. \& Sebben A. 2014. [Neurocranium osteology of Iguana iguana iguana (Squamata: Iguanidae).] Osteologia do neurocrânio de Iguana iguana iguana (Squamata: Iguanidae). Pesquisa Veterinária Brasileira 34(Supl.1):69-73. Laboratório de Anatomia Humana e Comparativa, Curso de Ciências Biológicas, Universidade Federal de Goiás, Regional Jataí, Cidade Universitária, BR-364 Km 192, Setor Parque Industrial, Jataí, G0 75801-615, Brazil. E-mail: fabianocl21@hotmail.com

Skull represents the segment with conspicuous adaptations that, in lizards, may be conservative or promoted by selective pressures. The aim of assisting the morphological knowledge of reptiles, we provide a detailed description of the neurocranium of Iguana iguana iguana based on analysis of three dried adult skeletons. The skull of this species has basal characteristics in lizards without closure of cranial openings and general triangular shape. Bony structures that form the caudal base have many fusions, especially on the floor. In the caudal face the exoccipital and the opisthotic are fused and form the otooccipital, which contributes to the formation of the lateral part of the condyle. The central part is formed by the condyle supraocciopital. Fusions and skeletal structures in Iguana are similar to other lizards. There are no autopomorphies in the neurocranium for this species.

INDEX TERMS: Iguana iguana iguana, green iguana, reptiles, neurocranium, skull, skeleton.
\end{abstract}

RESUMO.- O crânio representa o segmento com conspícuas adaptações que, nos lagartos, podem ser conservativas ou impulsionadas por pressões seletivas. Objetivando subsidiar o conhecimento morfológico dos répteis, fornecemos uma descrição detalhada dos ossos que formam o neurocrânio de Iguana iguana iguana com base na análise de três esqueletos secos de espécimes adultos. 0 crânio da referia espécie possui características basais entre os lagartos sem o fechamento das aberturas cranianas e formato geral triangular. As estruturas ósseas que formam a base craniana apresentam muitas fusões, principalmente no assoalho. Na face caudal o exoccipital e o opistótico estão fundidos

\footnotetext{
${ }^{1}$ Recebido em 6 de outubro de 2014.

Aceito para publicação em 30 de dezembro de 2014.

${ }^{2}$ Laboratório de Anatomia Humana e Comparativa, Curso de Ciências Biológicas, Universidade Federal de Goiás, Regional Jataí, Cidade Universitária, BR-364 Km 195, Setor Parque Industrial, Jataí, GO 75801-615, Brasil. *Autor para correspondência: fabianocl21@hotmail.com

${ }^{3}$ Departamento de Zoologia, Instituto de Biociências de Rio Claro, Universidade Estadual Paulista Júlio de Mesquita Filho. Avenida 24A, 1515, Cx. Postal 199, Bela Vista, Rio Claro, SP 13506-900, Brasil.

${ }^{4}$ Laboratório de Anatomia Comparativa dos Vertebrados, Departamento de Ciências Fisiológicas, Universidade de Brasília, Campus Darcy Ribeiro, Instituto de Ciências Biológicas, Bloco E, térreo, guichê da Pós-Graduação em Biologia Animal, Brasília, DF 70910-900, Brasil.
}

e formam o otoccipital, que contribui para a formação dos terços laterais do côndilo occipital. A parte central do côndilo é formada pelo supraoccipital. Fusões e estruturas esqueléticas presentes em Iguana são similares aos demais lagartos. Não foram descritas autapomorfias no neurocrânio para esta espécie.

TERMOS DE INDEXAÇÃO: Iguana iguana iguana, iguana verde, répteis, crânio, esqueleto.

\section{INTRODUÇÃo}

Empregado como ferramenta para desvendar aspectos da biologia evolutiva e na reconstrução de filogenias (Shubin \& Alberch 1986, Mabee et al. 2000, Gilbert et al. 2001), o conhecimento morfológico auxilia também na compreensão das tendências funcionais e das preferências ambientais em diferentes estágios de desenvolvimento. 0 esqueleto é suficientemente conservativo, a ponto do seu padrão geral mostrar as amplas linhas filogenéticas dos vertebrados, desempenhando fundamental papel funcional, apresentando plasticidade para responder aos hábitos particulares dos vários animais (Hildebrand \& Goslow 2006).

Dentre os elementos esqueléticos, o crânio dos vertebrados corresponde ao segmento corporal com as maiores adaptações e responde de maneira satisfatória as necessi- 
dades destes animais. Desempenha funções importantes para proteção, estabilidade e acuidade de todos os sistemas neuro-sensoriais da cabeça e dos aparelhos de alimentação e respiração (Kearney et al. 2005, Herrel et al. 2007). Cada grupo de animais possui características distintas em sua anatomia craniana o que, dentre outras aplicações, são utilizadas de ampla forma para a descrição de relações filogenéticas (Rieppel 1984, Benton 1985,Herrel et al. 2007, Conrad \& Norell 2010, Jerez 2012). Nos lagartos, sua anatomia pode ser conservativa em para algumas características sendo impulsionada pelas demandas de construção impostas por pressões seletivas. Assim, este segmento do esqueleto é ideal para explorar como as diferentes pressões seletivas e restrições tendem a agir para moldar a evolução de um sistema integrado complexo (Herrel et al. 2007).

Popularmente como iguana verde, Iguana iguana iguana (Linnaeus, 1758) se distribui pelas Américas e no Brasil ocorre nos biomas Amazônia, Caatinga, Pantanal (Campos 2004, Swanson 2004, Campos \& Desbiez 2013). Possuem hábitos arborícolas (Lazel 1973, Swanson 2004) e cavam os ninhos no solo (Rodda 1990). Pertencem a família Iguanidae, cujas características diagnósticas são, fusão da premaxila, presença de tuberosidade prefrontal, processo ventromedial do pterigóide, quilhas presentes na vértebra cervical e planos de autotomia caudal presentes posteriormente aos processos transversais (Conrad 2008).

Embora existam algumas descrições da morfologia craniana de lagartos do grupo Iguania (Abdala et al. 1997, Torres-Carvajal 2003, Silva \& Verrastro 2007, Banzato et al. 2012), os relatos acerca da anatomia pormenorizada de $I$. iguana iguana são genéricos ou relatam pontualmente alguns aspectos (Conrad \& Norell 2010, Banzato et al. 2012). Objetivando contribuir com o conhecimento morfológico dos lagartos, fornecemos aqui uma descrição detalhada do neurocrânio de I. iguana iguana.

\section{MATERIAL E MÉTODOS}

Três espécimes adultos de I. iguana iguana (dois machos e uma fêmea) que morreram por causas naturais no Jacarezário da UNESP de Rio Claro foram preparados seguindo métodos osteológicos usuais. Todo tecido mole (tegumento, músculos e vísceras) foi removido com auxílio de bisturi, tesoura e faca deixando o esqueleto exposto e o mais limpo possível. Alguns segmentos foram desarticulados (membros, coluna vertebral, cauda e crânio) e levados à cocção por uma hora, retirados o excesso de tecido mole, e banhados com água quente por mais 30 minutos. Estes foram colocados em solução de peróxido de hidrogênio (3\%), identificados, fotografados e documentados.

A colônia de iguanas mantidas na Unesp-Rio Claro/SP é devidamente licenciada pelo ICMBIO-IBAMA no.973766. A investigação está amparada pelo parecer do comitê de ética da Universidade Federal de Uberlândia sob protocolo CEUA 070/2012. A utilização do material cadavérico animal é respaldado pela Instrução Normativa número 154/2007 do IBAMA e pela legislação vigente (Lei número 11.794/2008 que regulamenta Pesquisas com Animais no Brasil).

\section{RESULTADOS}

Basioccipital (Basioccipitale). Está posicionado entre as capsulas ópticas e forma a parede caudal da caixa craniana e a porção media do côndilo occipital (condylus occipitalis). Articula-se amplamente com o parabasisfenóide rostralmente. Articula-se com o processo inferior do pró-ótico (processus inferioris) rostrolateralmente e com a crista tuberal do otoccipital (crista tuberalis) laterocaudalmente (Fig.1B, C).

Supraoccipital (Supraoccipitale). Está orientado rostrodorsalmente. Apresenta forma similar a uma sela que repousa caudoventralmente ao parietal e forma a porção caudal do teto do crânio. Sua porção medial forma a borda dorsal do forame magno (foramen magnum). A margem ventrolateral articula-se com a margem dorsolateral do processo alar do pró-ótico (processus alaris) rostralmente e com a margem posterocaudal do corpo do otoccipital caudalmente. As faces ventrocaudal e dorsocaudal possuem uma depressão, um recesso côncavo orientado anteromedialmente que constitui a metade anterior da bula auditória (auditory bulla), a metade anterior é formada pelo otoccipital. Sua porção mais caudal possui duas depressões côncavas lateralmente orientadas. Na porção mediana desta face, uma crista protuberante e delgada separa as referidas depressões. A superfície dorsal contata o parietal e exibe, próximo a linha mediana, dois pequenos tubérculos lateralmente dispostos a crista mediana do supraoccipital (Fig.1C).

Parabasisfenóide (Parabasisphenoidale). A porção dérmica deste elemento é fundida com o basisfenóide e, portanto, indistinguível, exceto por um longo e delgado processo cultriforme rostromedial (processus cultriforme). Assim, esses ossos são descritos genericamente como um único elemento assim denominado. Ele forma o assoalho do crânio e se articula com o basioccipital caudalmente e com o pró-ótico dorsalmente. Suas bordas ventrolateral e rostrodorsal são formadas pela crista selar transversa (crista sellaris). Ele possui três pares de processos em adição ao processo cultriforme. Dois delgados, planos e laterocaudais processos que sobrepõem o basioccipital rostrolateralmente e se estendem na face rostrodorsal até o tubérculo esfenoccipital (tuberculum sphenoccipitale). Entre as extremidades destes processos, a superfície ventral apresenta um recesso. Rostralmente dois processos basipterigóideos (processus basipterigoideus), orientados ventrolateralmente, estão presentes e expandem esta extremidade. Esta porção articula-se com o pterigóide. Dorsal a cada processo basipterigóide existe um pequeno processo alar dorsolateral (processus alaris). As extremidades deste processo e da porção anterior do processo anteroventral do pró-ótico estão aderidos à pila antótica (pilae antotica). Lateralmente é perfurado, na base de cada processo posterolateral, por um canal carótico (canalis caroticus), que percorre a porção ventrolateral na superfície anterior. 0 delgado e alongado processo cultriforme repousa sobre a trabécula comum (trabecula communis) e se estende rostrodorsalmente até o ponto correspondente ao limite posterior da maxila, dorsalmente ao espaço piriforme (Fig.1).

Otoccipital (Otoccipitale). Formando pela fusão do exoccipital e opistótico. Estes elementos serão então descritos como únicos. Este forma a parede posterior do crânio e contata o pró-ótico rostrolateralmente, o supraoccipital 
dorsomedialmente e o basioccipital ventromedialmente. Forma a margem lateral do forame magno e a porção late-

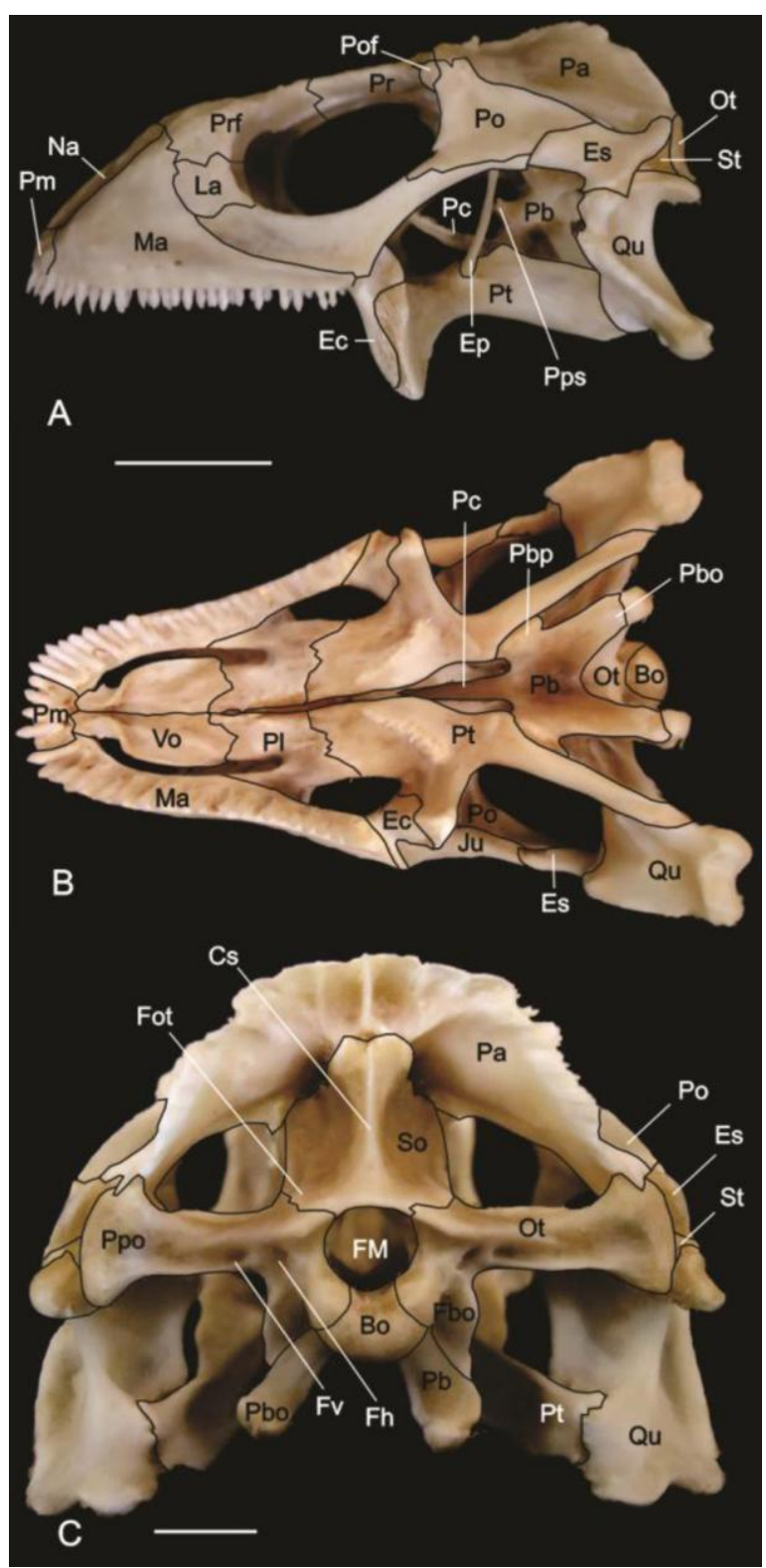

Fig.1. (A) Crânio de Iguana iguana iguana em vista lateral, (B) vista palatal e (C) vista caudal. Basioccipital (Bo), crista sagital (Cs), ectopterigóide (Ec), epipterigóide (Ep), esquamosal (Es), faceta basioccipital (Fbo), forame hipoglosso (Fh), forame magno (FM), faceta otoccipital (Fot), forame vagal (Fv), jugal (Ju), lacrimal (La), maxila (Ma), nasal ( $\mathrm{Na})$, otoccipital $(\mathrm{Ot})$, parietal $(\mathrm{Pa})$, parabasisfenóide $(\mathrm{Pb})$, processo basioccipital $(\mathrm{Pbo})$ processo basipterigóide $(\mathrm{Pbp})$, processo cultriforme $(\mathrm{Pc})$, pré-frontal (Pfr), palatino (Pl), pré-maxila (Pm), pós-orbital (Po), pós-frontal (Pof), processo paroccipital (Ppo), processo paresfenóide (Pps), frontal (Pr), pterigoide (Pt), quadrado $(\mathrm{Ou})$, supraoccipital (So), supratemporal (St), vômer (Vo). Barra $=2 \mathrm{~cm}$. ral do côndilo occipital. Possuem um processo paroccipital (processus par occipitalis). A superfície interna deste possui uma depressão côncava em forma de recesso que compreende na metade posterior da bula auditória. Os forames hipoglosso e vagal estão presentes na porção caudal. 0 processo paroccipital estende-se laterocaudalmente como um par de barras robustas e quadrangulares. Sua porção lateral apresenta uma pequena dilatação similar a um tubérculo que contata o quadrado, o parietal e o supratemporal. A extremidade lateral de cada processo paroccipital é sobreposta pela extremidade posterior do supratemporal rostralmente, o processo supratemporal do parietal (processus supratemporalis) dorsalmente e a ventralmente. 0 esquamosal também contata discretamente este. Anterior ao processo paroccipital, cada otoccipital possui um recesso jugular (recessos jugularis). Caudalmente exibe uma crista tuberal (crista tuberalis), que possui lateralmente um forame hipoglosso ventral (canalis nervus hipoglossi ventralis). Esta porção do otoccipital ainda possui três forames hiploglossos juntamente dispostos com o forame vagal (Fig.1).

Orbitoesfenóide (Orbitosphenoidei). Correspondem em um par de elementos ossificados na parte anterior do neurocrânio. São alongados, côncavos caudalmente, cranialmente ao parabasisfenóide e cartilagem intercalar (cartilago intercalaris) medialmente dispostos aos epipterigóides. Limitam a margem lateral da fenestra óptica (fenestra optica).

Pró-ótico (Prooticum). Posicionados na parede rostrolateral do crânio possui, cada um, três processos, o processo alar (processus alaris), o rostroventral (processus rostroventralis) e o dorsocaudal (processus dorsocaudalis). 0 processo alar é pequeno e rostrodorsalmente orientado com a margem lateral do supraoccipital, caudalmente. A margem rostral do processo alar forma a crista alar (crista alaris). 0 processo rostroventral articula-se com o parabasisfenóide rostralmente e com o basioccipital ventralmente. Este possui ventralmente uma ampla cavidade perfurada pelo forame facial (foramen facialis). A margem lateral deste processo forma a metade anterior da crista pró-ótica. 0 processo dorsocaudal sobrepõe a superfície rostral do processo paraoccipital do otoccipital e a margem medial forma a margem anterior da fenestra oval. Este recesso forma o assoalho e a parede medial da cavidade timpânica.

\section{DISCUSSÃO}

De maneira geral o crânio mantém as características de lagartos ancestrais, sem o fechamento das aberturas cranianas (George \& Smallwood 1992). George \& Smallwood (1992) e Banzato et al. (2012) relatam que o crânio de Iguania é grosseiramente triangular na vista dorsal e com uma pequena região pré-orbital, mesmas características encontradas em I. iguana iguana. Dentre as espécies de lagartos, aquelas que apresentam tamanho reduzido possuem crânios largos e fundidos (Riepel 1984, Müller 2002). Em I. iguana iguana o crânio pode ser considerado grande em relação ao grupo de lagartos no geral, mas esta é uma característica relacionada ao porte do animal. As estruturas ósseas estão bem delimitadas e não existem processos aparentes de fusão, exceto na parte caudal e assoalho craniano. 
Posicionados na parte caudal, os ossos que limitam a caixa craniana são o basioccipital, supraoccipital, exoccipital, opstótico (ou otoccipital, quando estão fundidos), parabasisfenóide, proótico, epiótico e orbitoesfenóide. Supraoccipital e basioccipital são ossos ímpares, e formam parte do teto e assoalho craniano, respectivamente. Este último contribui para a parte mediana do côndilo. Em Anolis, Scincus e Lygosma não é possível averiguar a sutura entre o basioccipital e o exoccipital, sendo o côndilo formado provavelmente apenas pelo basioccipital. Tal sutura é perfeitamente diferenciada em I. iguana iguana, evidenciando a contribuição de elementos ósseos distintos na formação do côndilo, padrão averiguado nos demais lagartos (Romer 1956, Torres-Carvajal 2003, Khosravani et al. 2011) Lateralmente nesta região está posionado o par de proóticos que, nos lagartos adultos, não apresentam divisão conspícua entre os demais ossos do neurocrânio (Simões-Lopes e Krause, 1988) e limitam lataralmente o forame magno.

Vários são os relatos de fusão de estruturas do neurocrânio (pro-ótico, opistótico e exoccipital principalmente). Todos estes elementos possuem centros de ossificação distintos e são, normalmente, diferenciáveis nos jovens (Stephenson \& Stephenson 1956). Sua fusão pode estar associada ao grau de ossificação do crânio nestes animais (Jolie 1960).

0 otoccipital é par e lateralmente disposto na face caudal do crânio. Em L. occipitalis ele é formado pela união do exoccipital e opistótico, sendo este último diferenciado em algumas espécies (Oelrich 1956). Estes elementos estão fundidos em I. iguana iguana, tal como em Stenocercus guentheri (Torres-Carvajal 2003), Varanus prisca (Head et al. 2009), Eremias persica, Measalina watsonana (Khosravani et al. 2011), Shinisaurus crocodilurus (Bever et al. 2005), Naultinus (Stephenson \& Stephenson 1956), Ctenosauria pectinata e Sator grandaevus (Oelrich 1956, Etheridge 1962) dentre outros. A fusão acontecem ainda durante o desenvolvimento pré-natal em muitos lagartos (Maisano 2001) mas pode eventualmente ocorrer em jovens tal como relatado para $S$. crocodilurus (Bever et al. 2005). Este elemento forma o terço lateral do côndilo e a borda lateral do forame magno, delimitando a parede posterolateral do crânio. 0 par de processos paroccipitais são amplos e lateralmente dispostos contatando os osso quadrado, parietal e esquamosal (Head et al. 2009). 0 opstótico, quando diferenciado, é muito reduzido (Stephenson \& Stephenson 1956), embora nenhuma das descrições, inclusive para I. iguana iguana tal morfologia tenha sido observada.

Contribuindo na delimitação da margem rostral do processo paroccipital, o pró-otico forma a parede anterolateral do neurocrânio nos répteis em geral (Stephenson \& Stephenson 1956, Torres-Carvajal 2003, Bever et al. 2005, Bell et al. 2009, Head et al. 2009, Khosravani et al. 2011). Na transição com a região orbital, o orbitoesfenóide (lateroesfenóide, Romer 1956) é uma ossificação da parte dorsal da pila metótica, localizada na parte anterior da caixa craniana que contribui para a formação da parede posterior da órbita (Bellairs \& Kamal 1981, Torres-Carvajal 2003, Bell et al.
2009). Nos répteis, tal como em I. iguana iguana, trata-se de um pequeno par de ossos curvados que se formam próximo a linha mediana, anteriormente ao parabasisfenóide e medialmente aos epipterigóides. Bever et al. (2005) relatam sua presença em S. crocodilurus, embora Conrad (2004) e outros autores não tenham descrito o orbitoesfenóide na referida espécie. Em Xenosaurus sua presença é variável, e a ausência é relatada em Gekkota, Heloderma e Anniella (Jolie1960), representando provavelmente variações intraespecíficas ou mesmo problemas durante o preparo do material. Tarazona et al. (2008) relatam que em Bachia bicolor tratam-se de um largo e laminar par de ossos posicionados próximo a linha mediana, fechando anteriormente o neurocânio. Tal característica é similar as espécies do grupo Amphisbaenia e diferente dos demais répteis, onde estes normalmente não contatam outros ossos do crânio.

0 parabasisfenóide foi descrito em diversos lagartos (Head et al. 2003) e com a mesma topografia encontrada em Iguana, anterolateral na base do neurocânio. Abriga a cela turca, bem como os forames para artérias cerebrais e o nervo craniano VI. As relações filogenéticas e a anatomia deste elemento apresentam uma extensa discussão (Jolie 1960, Bellairs \& Kamal 1981). 0 padrão atribuído aos répteis é a fusão do paresfenóide e basisfenóide formando este elemento ímpar. Eremias persica, Measalina watsonana (Khosravani et al. 2011), Varanus (Head et al. 2003), S. crocodilurus (Bever et al. 2005), Moloch horridus (Bell et al. 2009) e I. iguana iguana apresentam os elementos paresfenóide e basisfenóide fundidos formando um único parabasisfenóide (Rieppel 1993, Torres-Carvajal 2003). Em Chamaeleo o paresfenóide é distinto, embora seja pouco desenvolvido. 0 processo cultriforme (rostro parabasisfenóide) está usualmente fundido a placa basal, podendo ser laminar ou como em Iguana, afilado e projetado rostralmente, alcançando a metade da extensão da órbita. Bever et al. (2005) relatam que em $S$. crocodilurus existe uma fontanela basicranial em alguns espécimes que apresentam uma área não ossificada na sutura basioccipital. Possivelmente seja uma heterocronia, haja vista não ser uma exclusividade da espécie e estar relacionado a idade dos espécimes. Nos exemplares de $I$. iguana iguana que avaliamos, todos adultos, a sutura estava visivelmente bem ossificada.

\section{CONCLUSÕES}

O Neurocrânio de I. iguana iguana possui todos os elementos ósseos descritos nos demais lagartos. Não foram descritas características particulares para a espécie na região do neurocrânio.

A fusão entre o opstótico e o exoccipital forma o otoccipital, e entre o paresfenóide e basisfenóide origina o parabasisfenóide tal como na maioria dos lagartos.

A parede anterior do crânio é aberta constando apenas o par de barras curvas do orbitoesfenóide que não se articulam com os demais ossos do crânio.

A morfologia geral desta estrutura é conservativa dentre os lagartos.

Agradecimentos.- Às biólogas Marina Sartori e Lucélia Vieira e ao professor André Quagliatto pelo empenho na aquisição do material. 


\section{REFERÊNCIAS}

Abdala F., Lobo F. \& Scrocchi. 1997. Patterns of ossification in the skeleton of Liolaemus quilmes (Iguania: Tropiduridae). Amp. Rep. 18:75-83.

Banzato T., Selleri P., Veladiano I.A., Martin A., Zanetti E. \& Zotti A. 2012. Comparative evaluation of the cadaveric, radiographic and computed tomographic anatomy of the heads of green iguana (Iguana iguana), common tegu (Tupinambis merianae) and bearded dragon (Pogona vitticeps). BMC Vet. Res. 8:53.

Bell C.J., Mead J.I. \& Swift S.L. 2009. Cranial osteology of Moloch horridus (Reptilia: Squamata: Agamidae). Rec. West. Aust. Mus. 25:201-237.

Bellairs A.d'A. \& Kamal A.M. 1981. The chondrocranium and the development of the skull in recent reptiles, p.1-283. In: Gans C. \& Parsons T.S. (Eds), Biology of the Reptilia: morphology. Academic Press, New York.

Benton M.J. 1985. Classification and phylogeny of diapsid reptiles. Zool. J. Lin. Soc. 84:97-164.

Bever G.S., Bell C.J. \& Maisano J.A. 2005. The ossified braincase and cephalic osteoderms of Shinisaurus crocodilurus (Squamata, Shinisauridae). Paleontol. Elect. 8:1-36.

Campos Z. \& Desbiez A.L.J. 2013. Structure of size and reproduction of green iguanas (Iguana iguana) in the Brazilian Pantanal. IRCF Reptiles and Amphibians 20: 53-56.

Campos Z. 2004. Iguana iguana (Sinimbu). Reproduction. Herpetol. Rev. 25:169.

Conrad J.L. \& Norell M.A. 2010. Cranial autapomorphies in two species of Iguana (Iguanidae: Squamata). J. Herpetol. 44:307-312.

Conrad J.L. 2004. Skull, mandible, and hyoid of Shinisaurus crocodilurus Ahl (Squamata, Anguimorpha). Zool. J. Lin. Soc. 141:399- 434.

Etheridge R. 1962. Skeletal variation in the Iguanidae lizard Sator grandaevus. Copeia 1962:613-619.

George T.F. \& Smallwood J.E. 1992. Anatomic atlas for computed tomography in the mesaticephalic dog: head and neck. Vet. Radiol. Ultrasound 33:217-240.

Gilbert S.F., Loredo G.A., Brukman A. \& Burke A.C. 2001. Morphogenesis of the turtle shell: the development of novel structure in tetrapod evolution. Evol. Dev. 3:47-58.

Herrel A., Schaerlaeken C., Meyers J.J., Metzger K.A. \& Ross C.F. 2007. The evolution of cranial design and performance in squamates: Consequences of skull-bone reduction on feeding behavior. Integr. Comp. Biol. 47:107-117.

Hildebrand M. \& Goslow G.E. 2006. Análise da estrutura dos vertebrados. Atheneu, São Paulo.

Jerez A. 2012. Caracteristicas estruturales del esqueleto en Mabuya sp. (Squamata: Scincidae): una comparatión con escíncidos africanos. Actualidades Biológicas 34:207-223.

Jolie M.T. 1960. The head skeleton of the lizard. Acta Zool. 41:1-64.

Kearney M., Maisano J.A. \& Rowe T. 2005. Cranial anatomy of the extinct
Amphisbeanian Rhineura hatcherii (Quamata, Amphisbaenia) Based on High-Resolution X-Ray Computed Tomography. J. Morphol. 264:1-33.

Khosravani A., Rastegar-Pouyani N. \& Oraie H. 2011. Comparative skull osteology of the lacertid lizards Eremias persica and Mesalina watsonana (Sauria: Lacertidae). Iran. J. Ani. Biosyst. 7:99-117.

Khosravani A., Rastegar-Poyani N. \& Oraie H. 2011. Comparative skull osteology of the lacertid lizards Eremias persica and Mesalina watsonana (Sauria: Lacertidae). Iran. J. Anim. Biosyst. 7:99-117.

Lazell J.D.JR. 1973. The lizard genus Iguana in the Lesser Antilles. Bul. Mus. Comp. Zool. 145:1-28.

Mabee P.M., Otmstead K.L. \& Cubbage C.C. 2000. An experimental study of intraspecific variation, developmental, timing, and heterochrony in fishes. Evol. 54:2091-2106.

Maisano J.A. 2001. A survey of state of ossification in neonatal squamates. Herpetol. Monogr. 15:135-157.

Müller J. 2002. Skull osteology of Parvilacerta parva, a small-sized lacertid lizard from Asia Minor. J. Morphol. 253:43-50.

Oelrich T.M. 1956. The anatomy of the head of Ctenosaura pectinata (Iguanidae). University of Michigan, Michigan.

Rieppel 0.1984. Miniaturization of the lizard skull: its functional and evolutionary implications. Symp. Zool. Soc. Lond. 52:503-520.

Rieppel 0. 1993. Patterns of diversity in the reptilian skull, p. 344-390. In: Hanken J. \& Hall B.K. (Eds), The Skull: patterns of structural and systematic diversity. University of Chicago Press, Chicago.

Rodda G.H. 1990. Highway madness revisited: Roadkilled Iguana iguana in the llanos of Venezuela. J. Herpetol. 24:209-211.

Romer A.S. 1956. Osteology of the Reptiles. University of Chicago Press, Chicago.

Shubin N.H. \& Alberch P.A. 1986. Morphogenetic approach to the origin and basic organization of the tetrapod limb. Evol. Biol. 20:318-390.

Silva C.M. \& Verrastro L. 2007. Descrição do esqueleto axial de Liolaemus arambarensis Verrastro, Veronese, Bujes \& Dias Filho (Iguania, Liolaemidae): regiões pré-sacral e sacral. Revta Bras. Zool. 24:1-11.

Simões-Lopes P.C.A. \& Krause L. 1988. Osteologia do sincrânio de Liolaemus occipitalis Boulenger, 1885 (Sauria, Iguanidae). Reta. Bras. Zool. 5(4):491-508.

Stephenson N.B. \& Stephenson M. 1956. The osteology of New Zealand geckos and its bearing on their morphological status. Trans. R. Soc. New Zealand 84:341-385.

Swanson P.L. 2004. The iguana: Iguana iguana iguana. Iguana 11:179-182.

Tarazona O.A., Fabrezi M. \& Ramírez-Pinilla M.P. 2008. Cranial morphology of Bachia bicolor (Squamata: Gymnophthalmidae) and its postnatal development. Zool. J. Lin. Soc. 152:775-792.

Torres-Carvajal 0. 2003. Cranial Osteology of the Andean Lizard Stenocercus guentheri (Squamata: Tropiduridae) and Its Postembryonic Development. J. Morphol. 255:94-113. 


\section{Anexo IV}

Tabela III: Resumo da sequência de ossificação do esqueleto axial de I. iguana iguana.

Premaxila

Septomaxila

Maxila

Nasal

Pré-frontal

Aăcxinal

Frontal

Parietal

Supratemporal

Pós-frontal

Pós-orbital

Esquamosal

Jugal

Vômer

Palatino

Ectopterigóide

Pterigóide

Dentário

Coronóide

Suprangular

Angular

Esplenial

Basioccipital

Supraoccipital

Parabasisfenóide

Otoccipital

Orbitoesfenóide

Pró-otico

Quadrado

Epipterigóide

Articular

Hióide

Ossículos da esclera

Vértebras cervicais

Vértebras dorsais

Vértebras lombares

Vértebras sacrais

Vértebras caudais

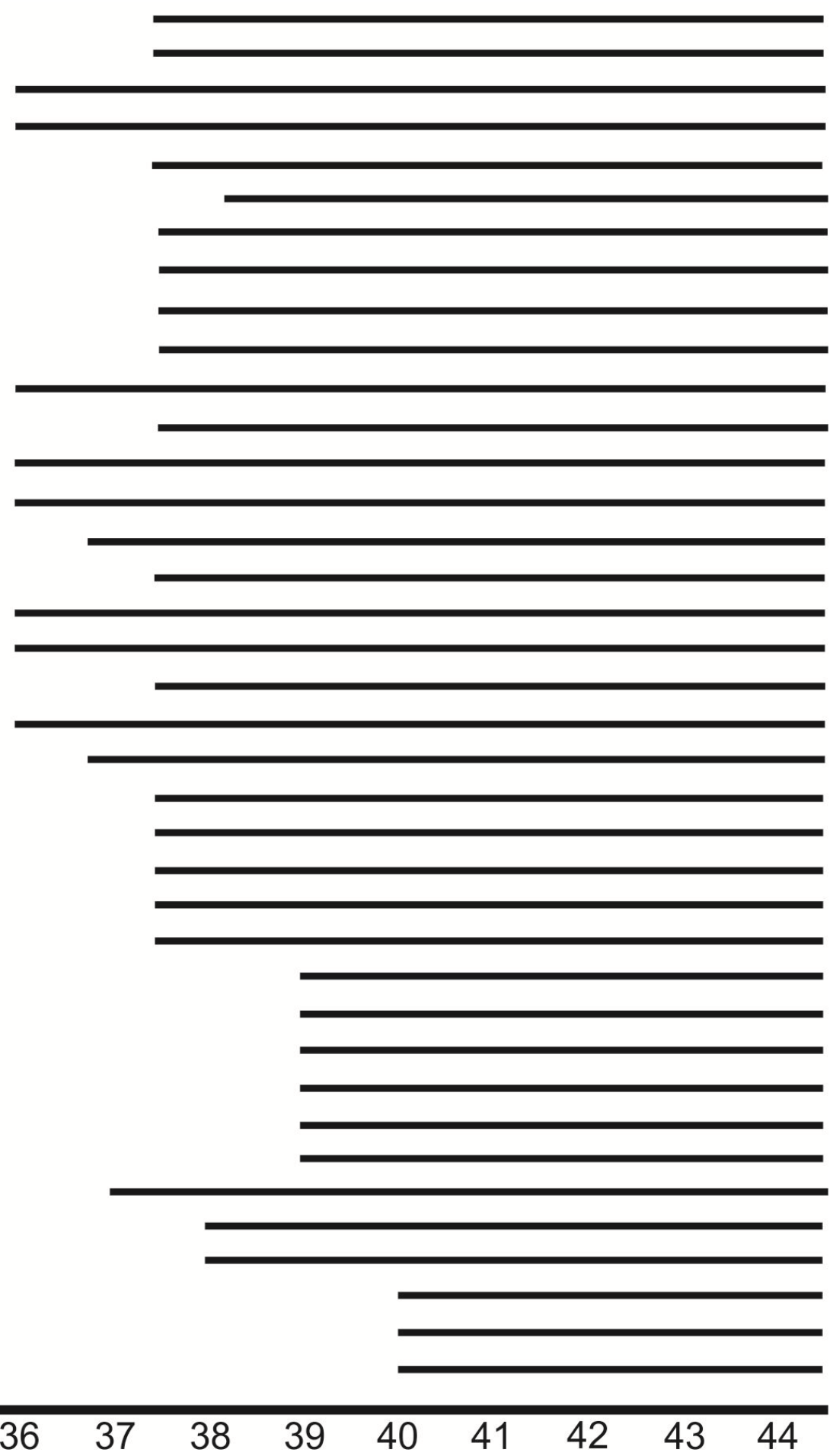


Anexo V

Tabela IV: Resumo da sequência de ossificação dos elementos da cintura e membros torácicos de I. iguana iguana.

\author{
Escápula \\ Coracóide \\ Úmero \\ Rádio \\ Ulna \\ Radial \\ Ulnar \\ Distal do carpo I \\ Distal do carpo II \\ Distal do carpo III \\ Distal do carpo IV \\ Distal do carpo V \\ Central \\ Intermédio \\ Pisiforme \\ Metacarpo I \\ Metacarpo II \\ Metacarpo III \\ Metacarpo IV \\ Metacarpo V \\ Falanges
}

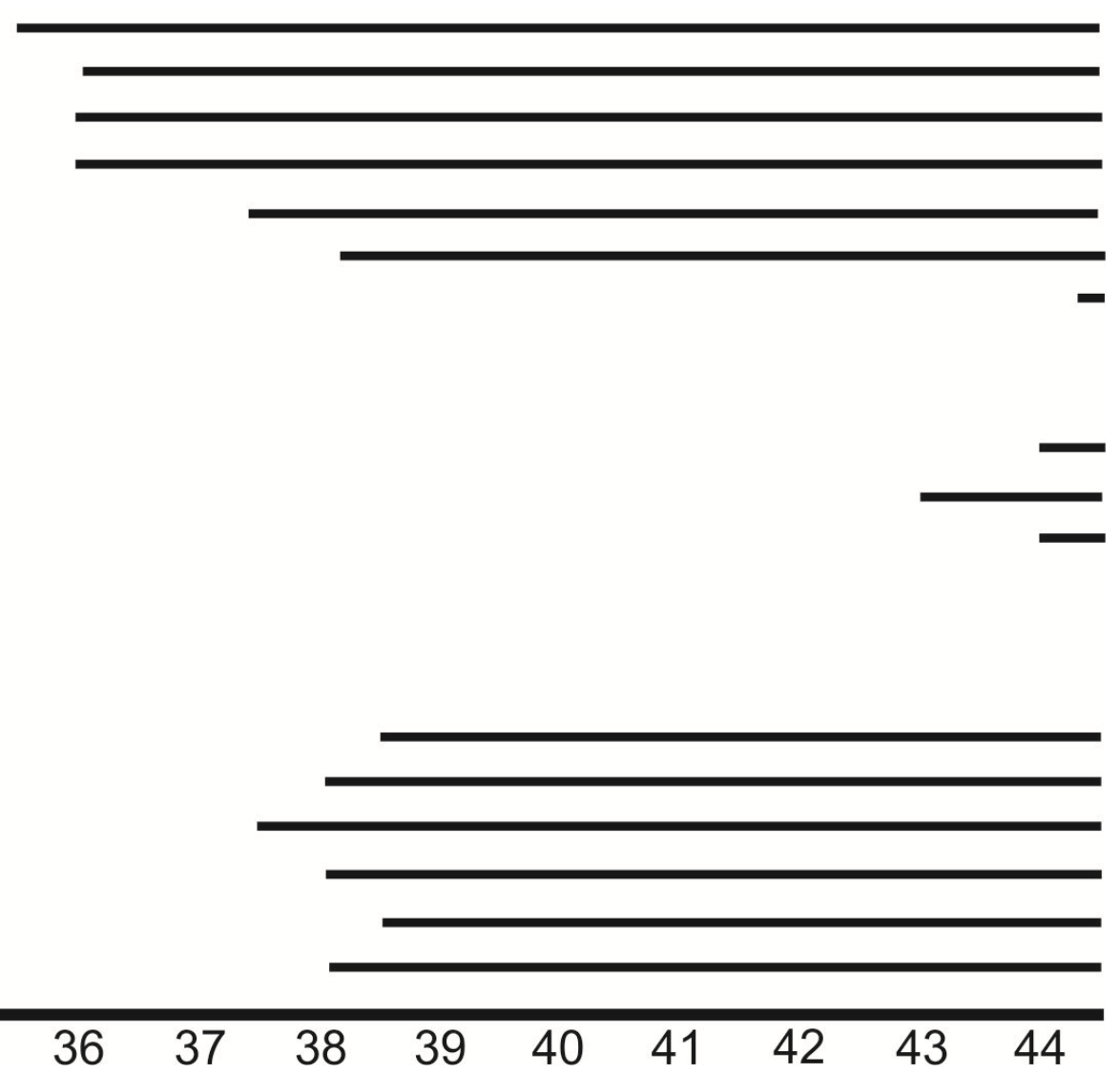


Anexo VI

Tabela V: Resumo da sequência de ossificação dos elementos da cintura e membros pelvinos de I. iguana iguana.

Ilíaco

Púbis

Ísquio

Fêmur

Tíbia

Fíbula

Proximal do tarso

Distal do tarso III

Distal do tarso IV

Metatarso I

Metatarso II

Metatarso III

Metatarso IV

Metatarso V

Falanges
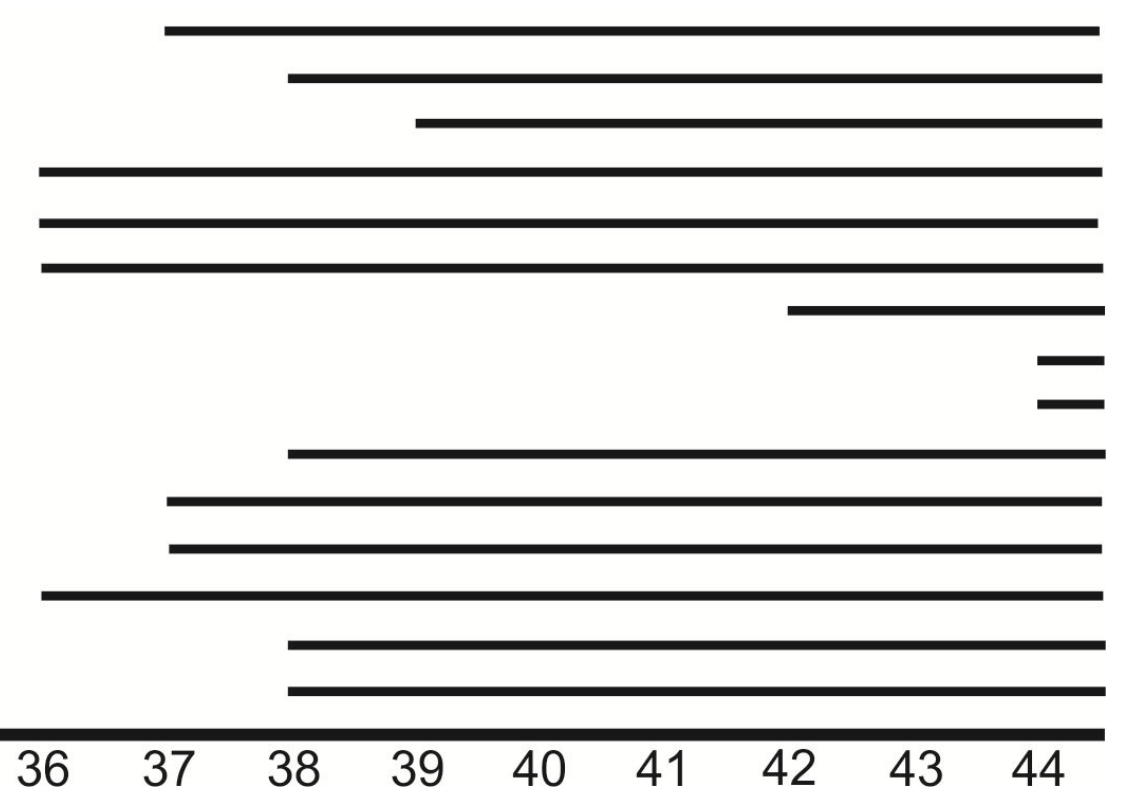


\section{REFERÊNCIAS}

Abdala, F.; Lobo, F.; Scrocchi. 1997. Patterns of ossification in the skeleton of Liolaemus quilmes (Iguania: Tropiduridae). Amphib-reptil. 18:75-83.

Adami, C.; Ofria, C.; Collier, TC. 2000. Evolution of biological complexity, PNAS, 97: 4463-4468.

Adriaens, D.; Verraes, W. 1998. Ontogeny of the Osteocranium in the African Catfish, Clarias gariepinus Burchell (1822) (Siluriformes: Clariidae): Ossification sequence as a response to functional demands. J. Morphol. 235:183-237.

Agassiz, L. 1857. Contribuitions to the natural history of the United States of Amarica. Fist monography in three parts - I. Essay on classification - II. North American Testudinata - III. The embryology of the turtle. Boston: Little, Brown \& Co. 643p.

Ahlberg, P. E.; Milner, A. R. 1994. The origin and early diversification of tetrapods. Nature 368:507-514.

Andrews, K. 1996. An endochondral rather than a dermal origin for scleral ossicles in Cryptodiran turtles. J. Herpetol. 30:257-260.

Andrews, R. M.; Greene, V. W. 2011. Character variation in embryonic development of the lizard Uta stansburiana. J. Herpetol. 45: 451-454.

Andrews, R. M.; Brandley, M. C.; Greene, V. W. 2013. Developmental sequences of squamate reptiles are taxon specific. Evol. Devel. 15:326-343.

Arcangelis, A.; Georges-Labouesse, E. 2000. Integrin and EMC functions: Roles in vertebrate development. Trands Gen. 16:536.

Avery, D. F.; Tanner, W. W. 1964. The osteology and myology of the head and thorax regions of the obesus group of the genus Sauromalus Dumeril (Iguanidae). Brigham Young Univ. Sci. Bull. Biol. Ser. 5:1-30.

Avery, D. F.; Tanner, W. W. 1971. Evolution of the Iguanine lizards (Sauria, Iguanidae) as determined by osteological and mycological characters. Brigham Young Univ. Sci. Bull. 12: $1-89$.

Ávila-Pires, T. C. S. 1995. Lizards of Brazilian Amazônia (Reptilia: Squamata). Zoologische Verhandelingen. 1-706.

Banzato, T.; P. Selleri, I.A.; Veladiano, A.; Martin, E.; Zanetti; Zotti, A. 2012. Comparative evaluation of the cadaveric, radiografic and computed tomographic anatomy of 
the heads of green iguana (Iguana iguana), common tegu (Tupinambis merianae) and bearded dragon (Pogona vitticeps). BMC Vet. Research, 8:1-11.

Banzato, T.; Selleri, P.; Veladiano, I. A.; Martin, A.; Zanetti E.; Zotti, A. 2012. Comparative evaluation of the cadaveric, radiographic and computed tomographic anatomy of the heads of green iguana (Iguana iguana), common tegu (Tupinambis merianae) and bearded dragon (Pogona vitticeps). BMC Vet. Res. 8:53.

Barberena, M. C.; Gomes, N. M. B.; Sanchotene, L. P. M. 1970. Osteologia craniana de Tupinambis teguixin. Publicação Especial da Escola de Geologia, 21:1-32.

Bauer, A. 1990. Phylogenetic systematics and biogeography of the Carphodactylini (Reptilia: Gekkonidae). Bonner Zool. Monogr. 30: 1-219.

Beegs, K.; Young, J.; Georges, A.; West, P. 2000. Ageing the eggs and embryos of the pignoise turtles, Carettochelys insculpta (Chelonia: Carettoclelydae), from northen Australia. Can. J. Zool. 78: 373-392.

Bell, C. J.; Mead, J. I.; Swift, S. L. 2009. Cranial osteology of Moloch horridus (Reptilia: Squamata: Agamidae). Rec. West. Aust. Mus. 25:201-237.

Bellairs, Ad'A.; Kamal, A. M. 1981. The chondrocranium and the development of the skull in recent reptiles. In: Gans, C.; Parsons, T. (eds.) Biology of the Reptilia, vol. 11. Morphology F. New York: Academic Press. pp. 1-263.

Benton, M. J. 1985. Classification and phylogeny of diapsid reptiles. Zool. J. Lin. Soc. 84: 97-164.

Berman, D. S.; Henrici, A. C. 2003. Homology of the astragalus and structure and function of the tarsus of Diadectidae. J. Paleont. 77:172-188.

Bever, G. S.; Bell, C. J.; Maisano J. A. 2005. The ossified braincase and cephalic osteoderms of Shinisaurus crocodilurus (Squamata, Shinisauridae). Paleontol. Elect. 8:1-36.

Billet, F.; Guns, C.; Maderson, P. F. A. 1985. Why study reptilian development? In: Gans, C.; Billet, F.; Maderson, P. F. A. (eds). Biology of the reptilia. Development A. Vol 14. New York: Wiley. p. 1-40.

Bininda-Emonds, O. R. P.; Jeffery, J. E.; Coates, M. I.; Richardson, M. K. 2002. From Haeckel to event-pairing: the evolution of developmental sequences. Theory Bioscience 121: 297-320.

Bininda-Emonds, O. R. P.; Jeffery, J. E.; Sánchez-Villagra, M. R.; Hanken, J.; Colbert, M.; Pieau, C.; Selwood, L.; ten Cate, C.; Raynaud, A.; Osabutey, C. K.; Richardson, M. K. 2007. 
Forelimb-hindlimb developmental timing changes across tetrapod phylogeny. BMC Evol. Biol. 7: 182-188.

Bizarro, G. H. F.; Soares, M. A. 2013. Osteologia craniana de Ameivula ocellifera. Revista eletrônica novo enfoque. 17:120-128.

Blackburn, D. G. 1995. Saltationist and punctuated equilibrium models for the evolution of viviparity and placentation. J. Theory Biol. 174:199-216.

Blanc, F. 1974. Table de développement de Chamaeleo lateralis gray, 1831. Ann. Embryol. Morphol. 7: 99-115.

Blob, R. W. 2000. Interspecific scaling of the hindlimb skeleton in lizards, crocodilians, felids and canids: does limb bone shape correlate with limb posture? J. Zool. 250: 507-531.

Boback, S. M.; Dichter, K.; Mistry, H. L. 2012. A developmental staging series for the African house snake, Boaedon (Lomprophis) fuliginosus. Zoology, 115; 38-46.

Bona, P.; Alcalde, L. 2009. Chondrocranium and skeletal development of Phrynops hilarri (Pleurodira: Chelidae). Acta Zool. (Stockholm), 90: 301-325.

Boughner, J. C.; Buchtová, M.; Fu, K.; Dewert, V.; Hallgrímsson, B.; Richman, J. M. 2007. Embryonic development in Python sebae - I: Staging criteria and macroscopic skeletal morphogenesis of the head and limbs. Zool. 110:212-230.

Breuker, C. J.; Debat, V.; Klingenberg, C. P. Functional evo-devo. TREE 21, 488-492. 2006.

Brock, G. T. 1940. The skull of the chamaeleon, Lophosaura ventralis (Gray); some developmental stages. Proc. Zool. Soc. Lon. 110: 219-241.

Broom, R. 1935. On the structure of the temporal region in lizard skulls. Ann. Transvaal Museum. 18: 13-22.

Buchtová, M.; Boughner, J. C.; Fu, K.; Diewert, V. M. \& Richman, J. M. 2007. Embryonic development of Python seabe - II: Craniofacial microscopic anatomy, cell proliferation and apoptosis. Zoology 110: 231-251.

Burghardt, G. M.; Rand, A. S. 1982. Iguana of the World: Their Behavior, Ecology, and Conservation. Noyes Publications, New Jersey. pp.472.

Burke, A. C.; Alberch, P. 1985. The development and homology of the chelonian carpus and tarsus. J. Morphol. 186:119-131. 
Burke, A. C.; Feduccia, A. 1997. Developmental patterns and the identification of the homologies of the avian hand. Science 278:666- 669.

Buscalioni, A. D.; Ortega, F.; Rassikin-Gutman, D.; Pérez-Moreno, B. P. 1997. Loss of carpal elements in crocodilian limb evolution: Morphogenetic model corroborated by paleobiological data. Biol J Linn Soc Lond 62:133-144.

Butler, A. B.; Northcutt, R. G. 1973. Architectonic studies of the diencephalon of Iguana iguana (Linnaeus). J. Comp. Neurol. 149: 439-461.

Caldwell, M. W. 1994. Developmental constraints and limb evolution in Permian and extant Lepidosauromorph diapsids. J. Vert. Paleontol. 14:459-471.

Caldwell, M. W. 1997. Limb osteology and ossification patterns in Cryptoclidus (Reptilia: Plesiosauria) with a review of sauropterygian limbs. J. Vert. Paleontol. 17:295-307.

Caldwell, M. W.; Carroll, R. L.; Kaiser, H. 1995. The pectoral girdle and forelimb of Carsosaurus marchesetti (Aigialosauridae), with a preliminary phylogenetic analysis of mosasauroids and varanoids. J. Vert. Paleontol. 15:516-531.

Camp, C. 1923. Classification of lizards. Bull. Am. Mus. Nat. Hist. 48: 289-481.

Campos, Z. 2004. Iguana iguana (Sinimbu). Reproduction. Herpetol. Rev. 25:169.

Campos, Z.; Desbiez A. L. J. 2013. Structure of size and reproduction of green iguanas (Iguana iguana) in the Brazilian Pantanal. IRCF Reptiles \& Amphibians. 20: 53-56.

Cannatella, D. C.; Hillis, D. M. 1993. Amphibian relationships: Phylogenetic analysis of morphology and molecules. Herpetol. Monogr. 7:1-7.

Carr, A.; Hirth, H. 1961. Social facilitation in green turtle siblings. Animal Behavior 9: 68-70.

Carrol, S. B. 2000. Endless forms: the evolution of gene regulation and morphological diversity. Cell 101:577-580.

Carroll, R. L. 1988. Vertebrate paleontology and evolution. New York: W. H. Freeman and Company.

Carroll, R. L. 1995. Problems of the phylogenetic analysis of paleozoic choanates. Bull. Mus. Nat. Hist. Nat. Paris 4:389-445.

Carroll, R. L.; Currie, P. J. 1991. The early radiation of diapsid reptiles. In: Schultze H-P.; Trueb, T. (eds.) Origin of the higher groups of tetrapods: Controversy and consensus. New 
York: Cornell University Press. p 354-424.

Casanova, J. C.; Uribe, V.; Badia-Careaga, C.; Giovinazzo, G.; Torres, M.; Sanz-Ezquerro, J. J. 2015. Apical ectodermal ridge morphogenesis in limb development is controlled by Arid3B-Mediated regulation of cell movements. Devel. 142:1195-1205

Coates, M. I. 1996. The Devonian tetrapod Acanthostega gunnari Jarvik: postcranial anatomy, basal tetrapod rela- tionships and patterns of skeletal evolution. Trans. R. Soc. Edinburgh: Earth Sciences 87:363-427.

Coates, MI. 1994. The origin of vertebral limbs. Developmental, 169-180.

Conrad, J. L. 2004. Skull, mandible, and hyoid of Shinisaurus crocodilurus Ahl (Squamata, Anguimorpha). Zool. J. Lin. Soc. 141:399- 434.

Conrad, J. L. 2008. Phylogeny and Systematics of Squamata (Reptilia) based on Morphology. Bull. Am. Mus. Nat. Hist. 310: 1-182.

Conrad, J. L.; Norell. M. A. 2010. Cranial autapomorphies in two species of Iguana (Iguanidae: Squamata). J. Herpetol. 44:307-312.

Cooper, W. E.; Vitt, L.J. 2002. Distribution, extent, and evolution of plant consumption by lizards. J. Zool. 257:487-517.

Cope, E. D. 1892. The osteology of the Lacertilia. Proc. Am. Phil. Soc. 30: 185-221.

Coulombre, A. J.; Coulombre, J. L.; 1973. The skeleton of the eye. II. Overlap of the scleral ossicles of the domestic fowl. Dev. Biol. 33:257-267.

Crastz, F. 1982. Embryological stages of the marine turtle Lepidochelys olivacea (Eschscholtz). Rev. Biol. Trop. 30:113-120.

Creuzet, S.; Vincent, C.; Couly, G. 2005. Neural crest derivatives in ocular and periocular structures. Int. J. Dev. Biol. 49:161-171.

Crumly, C. R.; Sánchez-Villagra, M. R. 2004. Patterns of variation in the phalangeal formulae of Land Tortoises (Testudinidae): Developmentl constraint, size, and phylogenetic history. J. Exp. Zool. (Mol Dev Evol) 302B:134-146.

Currie, P. J.; Carrol, R. 1984. Ontogenetic changes in the eosuchian reptile Thadeosaurus. . J. Vert. Paleontol. 4:68-84. 
Danni, T. M.; Dardenne, M. A.; Nascimento, S. M. 1990. Morphological study of the embryonic development of the Amazon turtle Podocnemis expansa, Pelomedusidae. Rev. Bras. Biol. 50: 619-625.

Davis, D. D.; Gore, U. R. 1936. Clearing and staining skeleton of small vertebrates. Field Museum of Natural History 4:3-15.

De Marco, V. 1992. Embryonic developmental times and egg retention in four species of sceloporine lizards. Functional Ecol. 6: 436-444.

DeLise, A. M.; Fischer, L.; Tuan, R. S. 2000. Cellular interactions and signaling in cartilage development. Osteoarthr Cartil. 8:309-334.

Deraniyagala, P. E. P. 1939. Tetrapod reptiles of Ceylon. Vol. I. Testudines and Crocodilians. Ceylon J.: Sd. Colombo Mus. Pub. J. 412 p.

Dhouailly, D.; Saxod, R. 1974. Les srades du développement de Lacerta muralis Laurent entre la ponte et l'éclosion. Bulletin Societé Zoologie France 99:489-494.

Digenkus, G.; Uhler, L. 1977. Differential staining of bone and cartilage in cleared and stained fish using alcian blue to stain cartilage and enzymes for clearing fish. Stain Technol. 52: 229-232.

Donayo, P.; Piña, C.; Larriera, A. 2002. Periodo de incubación, banda de calcificatión, peso de los uevos y desarrollo embrionário de Caiman latirostris a três temperaturas diferentes. In: Larriera, A.; Verdade, LM. (eds.) La conservatión y manejo de Caimanes y Crocodrilos de América Latina. Piracicaba: C. N. Editora. p. 79-90.

Dover G. 2000. How genomic and developmental dynamics affect evolutionary processes. BioEssay 22:1153-1159.

Dufaure, J. P.; Hubert, J. 1961. Table de développement du lézard vivipare: Lacerta (Zootoca) vivipara Jacquin. Arch. Anat. Micro. Morphol. Exp. 50:309-328.

Duprez, D.; Bell, E. J.; Richardson, M. K. 1996. Overexpression of BMP-2 and BMP-4 alters the size and shape of developing skeletal elements in the chick limb. Mech. Dev. $57: 145-157$.

El-Toubi, M. R. 1947. Some observations on the osteology of the lizard, Agama stellio (Linn.). J. Morphol. 81:135-149.

El-Toubi, M. R.; Kamal, A. M. 1959. The development of the skull of Chalcides ocellatus. I. The development of the chondrocranium. J. Morphol. 104:269-306. 
Elphick, M. J.; Shine. R. 1998. Longterm effects of incubation temperatures on the morphology and locomotor performance of hatchling lizards (Bassiana duperreyi, Scincidae). Biol. J. Linn. Soc. 63:429-447.

Ernelinnov, S. W. 1937. Die Morphologie der Tetrapodenrippen. Zool. Jahrb. Abt. Anat. Ontog. Tiere. 62:173-274.

Estes, R.; de Queiroz, K.; Gauthier, J. 1988. Phylogenetic relationships within Squamata. In: Estes, R.; Pregill, G. (eds.), Phylogenetic relationships of the lizard families: essays commemorating Charles L. Camp. Stanford University Press, Stanford, California, p. 119- 281.

Estes, R.; Pregill, G. 1988. Phylogenetic relationships of the lizard families. Stanford University Press, Stanford.

Estes, R.; Price, L. 1973. Iguanid lizard from Upper Cretaceous of Brazil. Science, 180:748-751.

Etheridge, R. 1962. Skeletal variation in the Iguanidae lizard Sator grandaevus. Copeia, 1962:613-619.

Evers Jr, P. R.; Soares, M. 2007. Descrição do crânio de Crocodilurus amazonicus spix, 1825 (Squamata, Teiidae). Arq. Mus. Nac. 65: 47-57.

Fabrezi, M.; Abdala, V.; Martínez-Oliver, M. I. 2007. Developmental basis of limb homology in lizards. Anat. Rec. (Hoboken) 290:900-912.

Fabrezi, M.; Barg, M. 2001. Patterns of carpal development among anuran amphibians. J. Morphol. 249:210-220.

Fabrezi, M.; Manzano, A.; Abdala, V.; Zaher, H. 2009. Developmental basis of limb homology in Pleurodiran turtles, and the identity of the hooked element in the chelonian tarsus. Zool. J. Lin. Soc. 155:845-866.

Federico, A.; Lobo, F. 2006. Patrones de osificacion en Tupinambis merianae y Tupinambis rufescens (Squamata: Teiidae) y patrones generales en Squamata. Cuadernos Herpetol. 20:3-23.

Ferguson, M. W. J. 1985. Post-laying stages of embryonic development in crocodilians. In: Gans, C.; Billet, F.; Maderson, P. F. A. (eds). Biology of the reptilia. New York: John Wiley and Sons. p. 329-491. 
Ferguson, M. W. J. 1987. Post-laying stages of embryonic development in crocodilians: In: Webb, G. J. W.; Manolis, S. C.; Whitehead, P. J. (eds). Wildlife management: crocodiles and alligators. Chipping Norton: Surrey Beatty \& Sons. p. 427-444.

Fisher, D. L.; Tanner, W. W. 1970. Osteological and myologycal comparisons of the head and thorax regions of Cnemidophorus tigris septentrionalis Burger and Ameiva undulata parva Barbour \& Noble (Family Teiidae). Brigham Young Univ. Sci. Bull. Biol. Ser. 11:139.

Fontanarrosa, G.; Abdala, V. 2014. Anatomical analysis of the lizard carpal bones in the terms of skilled manual abilities . Acta Zool. (Stockholm) 95:249-263.

Foster, E.; Hall, W. C. 1975. The connections and laminar organization of the optic tectum in a reptile (Iguana iguana). J. Comp. Neurol. 163:397-425.

Francis-West, P.; Ladher, R.; Barlow, A.; Graveson, A. 1998. Signalling interactions during facial development. Mech. Dev. 75:3-28.

Franz-Odendaal, T. A. 2008. Toward understanding the development of scleral ossicles in the chicken, Gallus gallus. Dev. Dynam. 237: 3240-3251.

Franz-Odendaal, T. A.; Hall, B. K. 2005. Anatomical variation and constraints on scleral ossicle formation in vertebrates. J. Morphol. 19:A245.

Franz-Odendaal, T. A.; Vickaryous, M. K. 2006. Skeletal elements in the vertebrate eye and adnexa: morphological and developmental perspectives. Dev .Dynam. 235: 1244-1255.

Fröbisch, N. 2008. Ossiication patterns in the tetrapod limb: Conservation and divergence from morphogenetic events. Biol. Rev. 83:571-600.

Fröbisch, N. B.; Neil, H. Shubin. 2011. Salamander limb development: Integrating genes, morphology, and fossils. Dev. Dynam. 240:1087-1099.

Frost, D. R.; Etheridge, R.; Janies, D. E.; Titus, T. A. 2001 Total evidence, sequence alignment, evolution of Polychrotid lizards, and a reclassification of the Iguania (Squamata: Iguania). Am. Mus. Novit. 3343:38.

Gaffney, E. S.; Meylan, P. A. 1988. A phylogeny of turtles. In: Benton, M. J. (ed). The phylogeny and classification of the tetrapods. Amphibians, Reptiles, Birds. Oxford: Clarendon. Vol. 1, p. 157-219.

Gaudin, A. J. 1978. The sequence of cranial ossification in the California Toad, Bufo boreas (Amphibia, Anura, Bufonidae). J. Herpetol. 12:309-318. 
Gauthier, J.; de Quieroz, K.; Estes, R. 1988. A phylogenetic analysis of Lepidosauromorpha. In: Estes. R.; Pregill, G. (eds.) Phylogenetic relationships of the lizard families. Stanford: Stanford University Press. pp 15-98.

George, T. F.; Smallwood, J. E. 1992. Anatomic atlas for computed tomography in the mesaticephalic dog: head and neck. Vet. Radiol. Ultrasoun. 33:217-240.

Ggins, G. M. 1923. Development of the primitive reptilian vertebral column, as shown by a study of Alligator mississippiensis. Am. J. Anat. 31:373-395.

Gilbert, S. F. Developmental Biology. Sunderland: Mass. Sinauer Associates. 2006.

Gilbert, S. F.; Loredo, G. A.; Brukman, A.; Burke, A. C. 2001. Morphogenesis of the turtle shell: the development of novel structure in tetrapod evolution. Evo. Dev. 3:47-58.

Good, D. A. 1995. Cranial ossification in the northern alligator lizard, Elgaria coerulea (Squamata, Anguidae). Amphib-reptil. 16:157-166.

Goodrich, E. S. 1916. On the classification of Reptilia. Proceed. Roy. Soc. London 89:261-276.

Graham, A. 2001. The developmental and evolution of the pharyngeal arches. J. Anat. 199: 133-141.

Grazziontin, F. G.; Fernandes, F. 2007. Análises evolutivas baseadas em dados moleculares e morfológicos: exemplos da herpetofauna brasileira. In: Nascimento, L. B.; Oliveira, M. E. (eds.) Herpetologia no Brasil II. Belo Horizonte - MG: Sociedade Brasileira de Herpetologia. Vol. 1, p. 326-354.

Greenbaum, E. B.; Carr, J. L. 2002. Staging criteria for embryos of the spiny softshell turtle, Apalone spinifera (Testudines: Trionychidae). J. Morphol. 254: 272-291.

Gregorovicova, M.; Zahradnicek, O.; Tucker, A. F.; Velensky, P.; Horacek, I. 2012. Embryonic development of the monitor lizard, Varanus indicus. Amphibia Rep. 33:451-468.

Guillette Jr, L. J. 1982. The evolution of viviparity and placentation in the high-altitude, Mexican lizard Sceloporus aeneus. Herpetologica 38:94-103.

Gutzke, W. H. N.; Packard, G. C. 1987. Influence of the hydric and thermal environments on eggs and hatchlings of bull snakes Pituophis melanoleucus. Physiol. Zool. 60:9-17.

Haas, A. 1999. Larval and metamorphic skeletal development in the fast-developing frog 
Pyxicephalus adspersus (Anura, Ranidae). Zoomorphol. 119:23-35.

Haeckel, E. 1868. Natürliche Schöpfungsgeschichte. Berlin: Georg Reimer.

Haeckel, E. 1874. Anthropogenie oder Entwickelungsgeschichte des Menschen. Leipzig: Engelmann.

Hall, B. K. 1992. Evolutionary Developmental Biology. Kluwer Academic Publishers.

Hall, B. K. 1999. The Neural Crest in Development and Evolution. New York: Springer.

Hall, B. K. 2007. Fins into limbs. Chicago: The University of Chicago Press. 433 p.

Hall, B. K.; Miyake, T. 1992. The membranous skeleton: the role of cell condensations in vertebrate skeletogenesis. Anat. Embryol. 186:107-124.

Hall, B. K.; Miyake, T. 1995. Divide, accumulate, differentiate: Cell condensation in skeletal development revisited. Int. J. Dev. Biol. 39:881-893.

Haluska, F.; Albrecht, P. 1983. The cranial development of Elaphe obsoleta (Ophidia, Colubridae). J. Morphol. 178: 37-55.

Hamburger, V.; Hamilton, H. L. 1951. A series of normal stages in the development of the chick embryo. Dev. Dynam. 195: 231-272.

Harrison, L.; Larsson, H. 2008. Estimating evolution of temporal sequence changes: a practical approach to inferring ancestral developmental sequences and sequence heterochrony. Systematic Biol. 57: 378-387.

Hedges, S. B.; Maxson, L. R. 1993. A molecular perspective on lissamphibian phylogeny. Herpetol. Monogr. 7:27-42.

Hernández-Jaimes, C.; Jerez, A.; Ramírez-Panilla, P. 2012. Embryonic development of the skull of the Andean lizard Ptychoglossus bicolor (Squamata, Gymnophthalmidae). J. Anat. 221:285-302.

Herrel, A.; Schaerlaeken, C.; Meyers, J. J.; Metzger, K. A.; Ross, C. F. 2007. The evolution of cranial design and performance in squamates: Consequences of skull-bone reduction on feeding behavior. Int. Comp. Biol. 47:107-117.

Hildebrand, M.; Goslow, G. E. 2006. Análise da estrutura dos vertebrados. Atheneu, São Paulo.

Hinchliffe, J. R. 1977. The chondrogenic pattern in chick limbmorphogenesis: A problem 
of development and evolution. In: Ede, D.A.; Hinchliffe, J.R.; Balk, M. (eds.) Vertebrate Limb and Somite Morphogenesis. Cambridge: Cambridge University Press, pp. 29S309.

Hinchliffe, J. R. 2002. Developmental basis of limb evolution. Inter. J. Dev. Bio. 48: 835845 .

Hinchliffe, J. R.; Hecht, M. K. 1984. Homology of the bird wing skeleton: embryological versus paleontological evidence. Evol. Biol. 18:21-29.

Hinchliffe, J. R.; Johnson, D. R. 1983. Growth of cartilage. In: Hall, B. K. (ed.) Cartilage: Development, differentiation and growth. Vol. 2. New York: Academic Press. p 255-296.

Hirth, H. F. 1963. The ecology of two lizards on a tropical beach. Eco. Monogr. 33:83-112.

Hofstetter, R.; Gasc, J. P. 1969. Vertebrae and ribs of modern reptiles. In: Gans. C.; Bellairs, Ad'A.; Parsons, T. S. (eds.) Biology of the reptilia. Morphology A. London: Academic Press. pp. 201-310.

Holmgren, N. 1933. On the origin of the tetrapod limb. Acta Zool. 14:185-295.

Howes, G. B.; Swinnerton, H. H. 1901. On the development of the skeleton of the Tuatara, Sphenodon punctatus; with remarks on the egg, on the hatchling, and on the hatched young. Trans. Zool. Soc. Lond. 16:1-86.

Hua, S.; Buffrenil, V. 1996. Bone histology as a clue in the interpretation of functional adaptations in the Thalattosuchia (Reptilia, Crocodylia). J. Vertebr. Paleontol. 16:703-71.

Hubert, J. 1985. Embryology of the Squamata. In: Gans, C.; Billet, F. (eds). Biology of the Reptilia. Vol. 15, Development B. New York: John Wiley and Sons. p. 1-34.

Huene, F. V. 1908. Ein Beitrag zur Beurteilung der Sacralrippen. Anatomischer Anzeiger. 33: $373-381$.

Hugi, J.; Mitgutsh, C.; Sánchez-Villagra, M. 2010. Chondrogenic and ossification patterns and sequences in White's skink Liopholis whitii (Scincidae, Reptilia), Zoosyst. Evol. 86:2132.

Inada, M.; Wang, Y.; Byrne, M. H.; Rahman, M. U.; Miyaura, C.; Lopez-Otin, C.; Krane, S. M. 2004. Critical roles for collagenase-3 (Mmp13) in development of growth plate cartilage and in endochondral ossification. Proc. Natl. Acad. Sci. 101:17192-17197.

Iungman, J., Piña, C. I. \& Siroski, P. 2008. Embryological development of Caiman latirostris (Crocodylia: Alligatoridae). Genesis 46: 401-417. 
Jabalee, J.; Hillier, S.; Franz-Odendaal, T. A. 2013. An investigation of cellular dynamics during the development of intramembranous bones: the scleral ossicles. J. Anat. 223:311-320.

Janke, A.; Erpenbeck, D.; Nilson, M.; Arnason, U. 2001. The mitochondrial genomes of the iguana (Iguana iguana) and the caiman (Caiman crocodylus): implications for amniote phylogeny. Proc. Royal Soc. B (Bio Sci), 268: 623-631.

Jeffery, J. E.; Bininda-Emonds, O. R. P.; Coates, M. I. \& Richardson, M. K. 2005. A new technique for identifying sequence heterochrony. Systematic Biol. 54: 230-240.

Jeffery, J. E.; Bininda-Emonds, O. R. P.; Coates, M. I.; Richardson, M. K. 2002. Analyzing evolutionary patterns in amniote embryonic development. Evo. Dev. 4: 292-302.

Jerez, A. 2012. Caracteristicas estruturales del esqueleto en Mabuya sp. (Squamata: Scincidae): Una comparatión con escíncidos africanos. Actualidades Biológicas. 34: 207-223.

Jerez, A.; Mangione, S.; Abdala, V. 2009. Occurrence and distribution of sesamoid bones in squamates: A comparative approach. Acta Zool. (Stockolm) 91:295-305.

Jerez, A.; Tarazona, O. A. 2009. Appendicular skeleton in Bachia bicolor (Squamata: Gymnophthalmidae): osteology, limb reduction and postnatal skeletal ontogeny. Acta Zool. (Stockholm) 90:42-50.

Ji, X.; Qiu, Q. B. \& Diong, C. H. 2002. Influence of the incubation temperature on hatching success, energy expenditure for embryonic development, and size and morphology od hatchings in the oriental garden lizard, Calotes versicolor (Agamide). J. Exp. Bio. 292: 649-659.

Jolie, M. T. 1960. The head skeleton of the lizard. Acta Zool. 41:1-64.

Karczmar, A. G.; Berg, C. G. 1951. Alkaline phosphatase during limb development and regeneration of Amblystoma opacum and Amblystoma punctatum. J. Exp. Zool. 117:139-163.

Kardong, K. L. 2010. Vertebrados: Anatomia comparada, função e evolução. São Paulo: Roca.

Kawakami, Y.; Rodriguez-León, J.; Belmonte, J. C. I. 2006. The role of TGFbs and Sox9 during limb chondrogenesis. Curr. Opin. Cell Biol. 18:723-729.

Kearney, M. 2003. Systematics of the Amphisbaenia (Lepidosauria: Squamata) based on morphological evidence from Recent and fossil forms. Herpetological Monographs 17:174. 
Kearney, M.; Maisano, J.A.; Rowe, T. 2005. Cranial anatomy of the extinct amphisbeanian Rhineura hatcherii (Squamata, Amphisbaenia) Based on High-Resolution X-Ray Computed Tomography. J. Morphol.. 264:1-33.

Keller, R. 1946. Morphogenetische Untersuchungen am Skelett von Sirenodon mexicanus SHAW mit besonderer Berücksichtigung des Ossiikationsmodus beim neotenen Axolotl. Revue Suisse de Zool. 53:329-426.

Khosravani, A.; Rastegar-Poyani, N.; Oraie, H. 2011. Comparative skull osteology of the lacertid lizards Eremias persica and Mesalina watsonana (Sauria: Lacertidae). Iran. J. Ani. Biosyst. 7:99-117.

King, G. 1996. Reptiles and herbivory. Chapman \& Hall, London.

Klembara, J. 2004. Ontogeny of the palatoquadrate and adjacent lateral cranial wall of the endocranium in prehatching Alligator mississippiensis (Archosauria: Crocodylia). J. Morphol. 262:644-658.

Klembara, J. 2005. Ontogeny of the partial secondary wall of the otoccipital region of the endocranium in prehatching Alligator mississippiensis (Archosauria, Crocodylia). J. Morphol. 266:319- 339 .

Kluge A. G. 1967. Higher taxonomic categories of gekkonids lizards and their evolution. Bull. Am. Mus. Nat. Hist. 135:1-59.

Krause L. 1978. Osteologia pós-craniana de Tupinambis teguxin (L., 1758) sensu Boulenger, Parte I: Esqueleto axial (vértebras e costela) (Lacertilia, Scincomorpha,Telidae). Rev. Bras. Biol. 46: 481-499.

Kuraku, S.; Usuda, R.; Kuratani, S. 2005. Comprehensive survey of carapacial ridgespecific genes in turtle implies cooption of some regulatory genes in carapace evolution. Evo. Dev. 7:3-17.

Lang, J. W.; Andrews, H.; Whitaker, R. 1989. Sex determination and sex ratios in Crocodilians. J. Exp. Zool. 270: 28-44.

Lazell, J. D. Jr. 1973. The lizard genus Iguana in the Lesser Antilles. Bul. Mus. Comp. Zool. 145:1-28.

Leal, F.; Tarazona, O. A.; Ramírez-Panilla, P. 2010. Limb development in the gekkonid lizard Gonatodes albogularis: A reconsideration of homology in the lizard carpus and tarsus, J. Morphol. 271:1328-1341.

Lee, M. S. Y. 1996. Correlated progression and the origin of turtles. Nature 379: 812-815. 
Lemmrichw. 1931. Der Skleral ring der Vagel. Jena. Z. Naturforsch. 65:513-586.

Lemus, A. D. 1967. Contribucion al studio de la embriologia de reptiles chilenos II. Tabla de desarollo de la lagatija vivipara Liolaemus gravenhorsti. Biology 40:39-61.

Lemus, A. D.; Duvalchelle, C. R. 1966. Desarollo intrauterine de Liolaemus tenuis tenuis (Dumeril y Bibron). Contribuicion al studio del desarollo embriologico de reptiles chilenos. Biology 39:80-98.

Lemus, D.; Illanes, J.; Fuezalida, M.; De La Vega, Y. P.; Garcia, M. 1981. Comparative analysis of the development of the lizard Liolaemus tenius tenius. II. A series of normal postlaying stages in embryonic development. J. Morphol. 169:337-349.

Levrat-Calviac, V.; Zylberberg, L. 1986. The structure of the osteoderms in the Gekko: Tarentola mauritanica. Am. J. Anat. 176:437-446.

Li, C.; Wu, X.; Rieppel, O.; Wang, L.; Zhao, L.2008. An ancestral turtle from the late Triassic of the southwesterns China. Nature 456: 497-501.

Licht, P.; Moberly, W.R. 1965. Thermal Requirements for Embryonic Development in the Tropical Lizard Iguana iguana. Copeia. 4: 515-517.

Lima, F. C.; Santos, A. L. Q.; Vieira, L. G.; Coutinho, M. E. 2011a. Sequência de ossificação do sincrânio e hioide em embriões de Caiman yacare (Crocodylia, Alligatoridae). Iheringia, Série Zoologia. 101:161-172.

Lima, F. C.; Vieira, L. G.; Santos, A. L. Q. Pereira, H. C.; De Simone, S. B. S.; Hirano, L. Q. L.; Romão, M. F.; Silva, J. M. M. \& Coutinho, M. E. 2011b. Skeletogenesis of the pectoral girdle and forelimbs in embryos of Caiman yacare (Daudin, 1802) (Crocodylia, Alligatoridae). J. Morphol. Sci. 28:1-7.

Lima, F. C.; Vieira, L. G.; Santos, A. L. Q.; De Simone, S. B. S.; Hirano, L. Q. L.; Silva, J. M. M.; Romão, M. F. 2009. Anatomy of the scleral ossicles in brazilian birds. Braz. J. Morphol. Sci. 26:165-169.

Lima, F. C.; Vieira, L. G.; Santos, A. L. Q.; Pereira, H. C.; Alves, P. H. M.; Assumpção, T. I. 2011c. Esqueletogênese dos ossos da coluna vertebral, costelas e esqueleto abdominal em embriões de Caiman yacare (Crocodylia: Alligatoridae). Bioscience J. 27: 813-825.

Lima, F. C.; Vieira, L. G.; Santos, A. L. Q.; Silva-Junior, L. M.; De Simone, S. B. S.; Silva, J. M. M.; Hirano, L. Q. L.; Romão, M. F.; Montelo, K. \& Malvázio, A. 2012. Ontogeny of the shell bones of embryos of Podocmenis unifilis. Anat. Rec. 294: 621-632. 
Lindley, D. M.; Hathcock, J. T.; Miller, W. W. 1988. Fractured scleral ossicles in a red tail hawk. Vet. Radiol. Ultrasound. 29:209-212.

Lobo, F.; Abdala, F.; Scrocchi, G. 1995. Desarrollo del esqueleto de Liolaemus scapularis (Iguania: Tropiduridae). Boll. Mus. Reg. Sci. Nat. 13:77-104.

Lobo, F.; Espinoza, R. E.; Quinteros, A. S. 2010. A critical review and systematic discussion of recent classification proposals for liolaemid lizards. Zootaxa 2549:1-30.

Mabee, P. M.; Otmstead, K. L.; Cubbage, C. C. 2000. An experimental study of intraspecific variation, developmental, timing, and heterochrony in fishes. Evol. 54:20912106.

Mabee, P.; Trendler, T. 1996. Development of the Cranium and Paired Fins in Betta splendens (Teleostei: Percomorpha): Intraspecific Variation and interspecific Comparisons. J. Morphol. 227: 249-287.

Macey, J. R.; Larson, A.; Ananjeva, N.B.; Papenfuss, T.J. 1997. Evolutionary shifts in three major structural features of the mitochondrial genome among iguanian lizards. J. Mol. Evol. 44: 660-674.

Machado, A. O. 2012. Ossificação pós-eclosão do crânio de Hemidactylus mabouia Moreau de Jonnés, 1808 (Lacertilia-Gekkonidae). Monografia Ciências Biológicas - UFPR. Curitiba, 2012.

Mackie, E. J.; Ahmed, Y. A.; Tatarczuch, L.; Chen, K. S.; Mirams, M. 2008. Endochondral ossification: How cartilage is converted into bone in the developing skeleton. Inter. J. Bioch. Cell Biol. 40: 46-62.

Magnusson, W. E.; Taylor, J. A. 1980. A description of developmental stages in Crocodylus porosus, for use in adding eggs in the field. Australian Wildlife Research 7:479485 .

Mahendra, B. C. 1949. The skull of the Indian house-gecko, Hemidactylus flaviridis Ruppel, Proc. Zool. Soc. 2:29-42.

Mahmoud, I. Y.; Hess, G. L.; Klicka, J. 1973. Normal embryonic stages of the western painted turtle, Chrysemys picta. J. Morphol. 141:269-280.

Maisano, J. A. 2001. A survey of state of ossification in neonatal squamates. Herp. Monogr. 15:135-157.

Maisano, J. A. 2002a. Postnatal skeletal ontogeny in Callisaurus draconoides and Uta stansburiana (Iguania: Phrynosomatidae). J. Morphol. 251:114-139. 
Maisano, J. A. 2002b. Postnatal skeletal ontogeny in five xantusiids (Squamata: Scleroglossa). J. Morphol. 254:1-38.

Mathies, T.; Andrews, R. M. 1999. Determinants of Embryonic Stage at Oviposition in the Lizard Urosaurus ornatus. Physiol. Bioch. Zool. 72:645-655.

Mathur, J. K.; Goel, S. C. 1976. Patterns of chondrogenesis and calcification in the developing limb of the lizard, Calotes versicolor. J. Morphol .149:401-420.

Mausfeld, P.; Schmitz, A.; Böhme, W.; Misof, B.; Vrcibradic, D.; Duarte-Rocha, C.F. 2002. Phylogenetic affinities of Mabuya atlantica Schmidt, 1945, endemic to the Atlantic Ocean archipelago of Fernando de Noronha (Brazil): necessity of partitioning the genus Mabuya Fitzinger, 1826 (Scincidae: Lygosominae). Zoologischer Anzeiger. 241: 281-293.

Maxwell, E. E.; Larsson, H. C. E. 2009. Comparative ossification sequence and skeletal development of the postcranium of palaeognathous birds (Aves: Palaeognathae). Zool. J. Linn. Soc. 157:169-196.

McCrady, E. 1938. The Embryology of the Opossum. Philadelphia: Wistar Institute of Anatomy and Biology.

McDowell, S. B.; Bogert, C.M. 1954. The systematic position of Lanthanotus and the affinities of the Anguinomorph Lizard. Bull. Am. Mus. Nat. Hist. 105.

Metzger, K.; Herrel, A. 2005. Correlations between lizard cranial shape and diet: a quantitative, phylogenetically informed analysis. Bio. J. Lin. Soc. 86: 433-66.

Miller, J. D. 1985. Embryology of marine turtles. In: Gans, C.; Billet, F.; Maderson, P. F. A. (eds.) Biology of the Reptilia. New York: John Wiley and Sons. p.269-328.

Mohammed, M. B. H. 1988. Sequence of ossification in the skeleton of growing lizard Chalcides ocellatus Forscal (Scincidae, Reptilia). Qatar Univ. Sci. Bull. 8:117-136.

Mohammed, M. B. H. 1991. Morphogenesis of the carpus and tarsus in the skink Chalcides ocellatus (Scincidae, Reptilia). J. Egyptian-German Soc. Zool 4:357-373.

Mouden, E. E.; Bons, J.; Pieau, C.; Renous, S.; Znari, M.; Boumezough, A. 2000. Table de développement embryonarie d'un agamidé, Agama impaleraris Borttger, 1874. Ann. Sci. Nat. Zool. 21:93-115.

Mrosovsky, N.; Yntema, C. L. 1980. Temperature dependence of sexual differentiation in sea turtles: implications for conservation practices. Biology Conservation 18: 271-280. 
Müller, G. B. 1991. Evolutionary transformation of limb pattern: Heterochrony and secondary fusion. In: Hinchliffe, J. R.; Hurlé, J. M.; Summerbell, D. (eds.) Developmental patterning of the vertebrate limb. New York: Plenum Press, 395- 405.

Müller, G. B.; Alberch, P. 1990. Ontogeny of the limb skeleton in Alligator mississippiensis: Developmental invariance and change in the evolution of archosaur limbs. J. Morphol. 203:151-164.

Müller, J. 2002. Skull osteology of Parvilacerta parva, a small-sized lacertid lizard from Asia Minor. J. Morphol. 253:43-50.

Müller, W. A.; Hassel, M. 2003. Entwicklungsbiologie und Reproduktionsbiologie von Mensch und Tier: ein einführendes Lehrbuch. Berlin: Springer-Verlag.

Muthukkarruppan, V. R.; Kanakambika, P.; Manickavel, V.; Veeraraghavan, K. 1970. Analysis of the development of the lizard, Calotes versicolor, I. A series of normal stages in the embryonic development. J. Morphol. 130: 479-490.

Nakamura, K.; Yamaguchi, H. 1991. Distribution of scleral ossicles in teleost fishes. Mem. Fac. Fish. Kagoshima Univ. 40:120.

Nieuwkoop, P. D.; Faber, J. 1994. Normal table of Xenopus laevis (Daudin). New York: Farland.

Noro, M.; Uejima, A.; Gembu, A.; Manabe, M.; Tamura, K. 2009. Normal developmental stages of the Madagascar Ground Gecko Paroedura pictus with special reference to limb morphogenesis. Dev. Dynam. 238:100-109.

O’Keefe, F. R.; Sidor, C. A.; Larsson, H. C. E.; Maga, A.; I. O. 2006. Evolution and homology of the astragalus in early amniotes: New fossils, new perspectives. J. Morphol. 267:415-425.

Oelrich, T. M. 1956. The anatomy of the head of Ctenosaura pectinata (Iguanidae). Miscellaneous Publications Of the University of Michigan. 94: 1-122.

Ohya, Y. K.; Kuraku, S.; Kuratani, S. 2005. Hox code in embryos of Chinese soft-shelled turtle Pelodiscus sinensis correlates with the evolutionary innovation in the turtle. J. Exp. Zool. (Mol Dev Evo). 304B:107-118.

Olaf, R. P.; Bininda-Emonds, M. C.; Kate, E. J.; Ross, D. E. MacPhee, R. M. D. B.-2007. The delayed rise of present-day mammals. Nature 446,507-512.

Olsen, B. R.; Reginato, A. M.; Wang, W. 2000. Bone development. Annual Review of Cell Developmental Biology 16:191-220. 
Oster, G. F. N.; Shubin, J. D.; Murray; Alberch, P. 1988. Evolutionany morphogenetic rules: The shape of the vertebrate limb in ontogeny and phylogeny. Evol. 42:862-884.

Packard, G. C.; Packard, M. J. 1984. Coupling of physiology of embryonic turtles to the hydric environment. In: Seymour, R. S. Respiration and metabolism of embryonic vertebrates. Doudrech: Junk Publishers. p. 99-199.

Packard, G. C.; Tracy, C. R.; Roth, J. J. 1977. The physiological ecology of reptile eggs and embryos, and the evolution of viviparity within the class Reptilia. Biol. Reviews 52:71105.

Pagel, M. 1997. Inferring evolutionary processes from phylogenies. Zoologica Scripta 26: 331-348.

Palmer, B. D.; De Marco, V. G.; Guillette, Jr. L. J. 1993. Oviductal morphology and eggshell formation in the lizard, Sceloporus woodi. J. Morphol. 217:205-217.

Panchen, A. L.; Smithson, T. R. 1988. The relationships of early tetrapods. In: Benton MJ. The phylogeny and classification of the tetrapods. Oxford: Clarendon Press, p 1-32.

Parkerw, K. 1879. On the structure and development of the skull in the Lacertilia. Phil. Trans. Roy. Soc. 170: 595-640.

Payne, S. L.; Holliday, C. M.; Vickaryous, M. K. 2011. An osteological and Histological investigation of cranial joints in Geckos. Anat. Rec. 294: 399-405.

Peter, K. 1904. Normentafeln zur entwicklungsgeschichte der zauneidechse (Lacerta agilis) vol 4. In: Fisher, G. (Ed). Jena: Keibel's Normentafeln, p. 1-65.

Piña, C. I.; Larriera, A.; Medina, M.; Weeb, G. J. W. 2007. Effects of incubation temperature on the size of Caiman latirostris (Crocodylia: Alligatoridae) at hatching and after one year. J. Herpetol. 41:209-214.

Pough, F. H.; Janis, C. M.; Heiser. J. B. 2003. A Vida dos Vertebrados. Atheneu, São Paulo.

Pyron, R. A.; Burbrink, F. T.; Wiens, J. 2013. A phylogeny and revised classification of Squamata, including 4161 species of lizards and snakes. BMC Evol. Biol. 13:1-53.

Ramaswami, L. S. 1946. The chondrocranium of Calotes versicolor (Daud.) with a description of the osteocranium of a just hatched young. Q. J. Microsc. Sci. 87:237-297.

Rao, M. K. M.; Ramaswami, L. S. 1952. The fully formed chondrocranium of Mabuya 
with an account of the adult osteocranium. Acta Zool. 33: 209-275.

Renous-Lécuru, S. 1973. Morphologie compare du carpe chez les Lepidosauriens actuels (Rynchocphales, Lacertiliens, Amphisbeniens). Gegenbaurs Morphogisches Jahrbbuch Leipzig 119:727 - 766.

Renous-Lécuru, S.; Rimblot-Baly, F.; Fretey, J.; Pieau, C. 1989. Caractéristiques du développement embryonnaire de la tortue Luth, Dermochelys coriacea (Vandelli, 1761). Ann. Sci. Nat. Zool. 10:197-229.

Richardson, M. K. 1995. Heterochrony and the Phylotypic Period. Dev. Biol. 172: 412421.

Richardson, M. K.; Carl, T. F.; Hanken, J.; Elinson, R. P.; Cope, C. 1998. Limb development and evolution: a frog embryo with no apical ectodermal ridge (AER). J Anat 192:379-390.

Richardson, M. K.; Gobes, S. M. H.; Van Leeuwen, A. C.; Polman, A. E.; Pieau, C.; Sánchez-Villagra M. R. 1999. Heterchrony in limb evolution: developmental mechanisms and natural selection. J. Exp. Zool. B (Mol Dev Evol) 312:1-26.

Richardson, M. K.; Hanken, J.; Gooneratne, M. L.; Pieau, C.; Raynaud, A. 1997. There is no highly conserved embryonic stage in the vertebrates: implications for current theories of evolution and development. Anat. Embryo. 196: 91-106.

Richardson, M. K.; Jeffery, J. E.; Coates, M. I.; Bininda-Emonds, O. R. P. 2001. Comparative methods in developmental biology. Zool. 104: 278-283.

Richardson, M. K.; Keuck, G. 2002. Haeckel's ABC of evolution and development. Bio. Review 77: 495-528.

Richardson, M. K.; Minelli, A.; Coates. M. I. 1999. Some problems with typological thinking in evolution and development. Evo Dev. 1:5-7.

Richardson, M. K.; Verbeek, F. J. 2003. New directions in comparative embryology and the nature of developmental characters. Animal Biol. 53: 303-311.

Rieppel, O. \& Grande, L. 2007. The anatomy of the fossil varanid lizard Saniwa ensidens Leidy, 1870, based on a new discovered complete skeleton. J. Paleontol. 81:643-665.

Rieppel, O. 1981. The skull and jaw adductor musculature in some burrowing scincomorph lizards of the genera Acontias, Typhlosaurus and Feylina. J. Zool. 195: 493-528.

Rieppel, O. 1984a. Miniaturization of the lizard skull: its functional and evolutionary 
implications. Symposia Zool. Soc London 52: 503-520.

Rieppel, O. 1984b. The structure of the skull and jaw adductor musculature in the Gekkota, with comments on the phylogenetic relationships of the Xantusiidae (Reptilia: Lacertilia). Zool. J. Linn. Soc. 82: 291-318.

Rieppel, O. 1987. The development of the trigeminal adductor musculature and associeted skull elements in the lizard Podarcis sicula: J. Zool. 212:131-150.

Rieppel, O. 1992a. Studies on skeleton formation in reptiles. I. The postembryonic development of the skeleton in Cyrtodactylus pubisculus (Reptilia: Gekkonidae). J. Zool. Lond. 227:87-100.

Rieppel, O. 1992b. Studies on skeleton formation in reptiles. III. Patterns of ossification in the skeleton of Lacerta vivipara Jacquin (Reptilia, Squamata), Fieldiana Zoo. 68:1-25.

Rieppel, O. 1992c. The skeleton of a juvenile Lanthanotus (Varanoidea). Amphib-reptil. 13:27-34.

Rieppel, O. 1993. Patterns of diversity in the reptilian skull, p. 344-390. In: Hanken, J.; Hall, B. K. (Eds.), The skull: Patterns of structural and systematic diversity. University of Chicago Press, Chicago.

Rieppel, O. 1993. Studies on skeleton formation in reptiles. II. Chamaeleo hoehnelii (Squamata: Chamaeleoninae), with comments on the homology of carpal and tarsal bones. Herpetologica, 49:66-78.

Rieppel, O. 1993. Studies on skeleton formation in reptiles. IV. The homology of the reptilian (Amniote) astragalus revisited. J. Vert. Paleontol. 13:31-47.

Rieppel, O. 1993d. Studies on skeleton formation in reptiles. v. Patterns of ossification in the skeleton of Alligator mississippiensis Dudin (Reptilia, Crocodylia), Zool. J. Lin. Soc. 109:301-325.

Rieppel, O. 1994a. Studies on skeleton formation in reptiles - patterns of ossification in the limb skeleton of Gehyra oceanica (Lesson) and Lepidodactylus lugubris (Dumeril \& Bibron). Ann. Sci. Nat. Zool. Biol. Anim. 15: 83-91.

Rieppel, O. 1994b. Studies on skeleton formation in reptiles. Patterns of ossification in the skeleton of Lacerta agilis exigua Eichwald (Reptilia, Squamata) , J. Herpetol. 28:145-153.

Rieppel, O.; Reisz, R. R. 1999. The origin and Early Evolution of Turtles. Ann. Rev. Ecol. Syst. 30: 1-22. 
Rieppel, O.; Zaher, H. 2001. The development of the skull in Acrochordus granulatus (Schneider) (Reptilia: Serpentes), with special consideration of the otico-occipital complex. J. Morphol. 249:252-266.

Risley, P. L. 1932. Observations on the natural history of the common musk turtle, Sternotherus odoratus (Latreille). Papers of the Michigan Academy of Science, Arts and Letters 17:685-711.

Robinson, P. L. 1975. The functions of the hooked fifth metatarsal in lepidosaurian reptiles. 596 Colloque Internationale. Centre Nationale Recherche Scientifique 218: 461-483.

Rodda, G. H. 1990. Highway madness revisited: Roadkilled Iguana iguana in the llanos of Venezuela. J. Herpetol. 24:209-211.

Romão, M. F.; Santos, A. L. Q. 2014. Anatomia óssea do crânio de Chellus fimbriatus (Reptilia: Chelidae). Bioscience J. 30: 512-517.

Romer, A. S. 1956. Osteology of the Reptiles. Chicago, IL: University of Chicago Press.

Romer, A. S.; Parsons, T. 1985. Anatomia Comparada dos Vertebrados. São Paulo: Atheneu.

Russell, A. P.; Bauer, A. M. 2008. The Appendicular locomotor apparatus of Sphenodon and normal-limbed squamates. In: Gans, C.; Gaunt, A. S.; Adler, K. (eds.) Biology of Reptilia. Vol. 21. The skull and appendicular locomotor apparatus of Lepidosauria, pp. 1-465. Society for the Study of Reptiles \& Amphibians, Contributions to Herpetology 24, Ithaca; New York.

Sánchez-Villagra, M. R.; Mitgutsch, C., Nagashima, H.; Kuratani, S. 2007a. Autopodial Development in the Sea Turtles Chelonia mydas and Caretta caretta. Zool. Sci. 24: 257-263.

Sánchez-Villagra, M. R.; Winkler, J. D.; Wurst, L. 2007b. Autopodial skeleton evolution in side-necked turtles (Pleurodira). Acta Zool. (Stockholm) 88:199-209.

Sánchez-Villagra, M. R.; Müller, H.; Sheil, C. A.; Scheyer, T. M.; Nagashima, H.; Kuratani, S. 2009. Skeletal development in the Chinese soft-shelled turtle Pelodiscus sinensis (Testudines: Trionychidae). J. Morphol. 270:1381-1399.

Sánchez-Villagra, M. R.; Ziermann, J. M.; Olsson, L. 2008. Limb chondrogenesis in Graptemys nigrinoda (Emydidae), with comments on the primary axis and the digital arch in turtles. Amphib-reptil. 29:85-92. 
Sanger, T. J.; Losos, J. B.; Gibson-Brown, J. J. 2008. A developmental staging series for the lizard Genus Anolis: A new system for the integration of evolution, development, and ecology. J. Morphol. 269:129-137.

Schaeffer, B. 1941. The morphological and functional evolution of the tarsus in amphibians and reptiles. Bull. Am. Mus. Nat. Hist. 78: 395-472.

Scheyer ,T.; Sander, M. 2004. Histology of ankylosaur osteoderms: implications for systematic and function. J. Vertebr. Paleontol. 24:874-893.

Scheyer, T. M.; Brüllmann, B.; Sánchez-Villagra, M. R. 2008. The ontogeny of the shell in side-necked turtles, with emphasis on the homologies of costal and neural bones. J. Morphol. 269:1008-1021.

Schlosser, G. 2001. Using Heterochrony Plots to Detect the Dissociated Coevolution of Characters. J Exp. Zool. (Mol Dev Evol) 291: 282-304.

Schulmeister, S.; Wheeler, W. C. 2004. Comparative and phylogenetic analysis of developmental sequences. Evo. Dev. 6:50-57.

Schulte, J. A.; Macey, J. R.; Larson, A.; Papenfuss, T. J. 1998. Molecular tests of phylogenetic taxonomies: a general procedure and example using four subfamilies of the lizard family Iguanidae. Mol. Phyl. Evol. 10:367-376.

Schulte, J. A.; Valladares, J. P.; Larson, A. 2003. Phylogenetic relationships within Iguanidae inferred using molecular and morphological data, and a phylogenetic taxonomy of iguanian lizards. Herpetologica 59: 399-419.

Schulz, I. P. 1975. Sea turtle nesting in Surinam. Nederlandsche Commissie voor Internationale Natuurbescherrning. Mededrlingen. 143 p.

Searls, R. L.; Janners, M. Y. 1971. The initiation of limb bud out-growth in the embryonic chick. Dev. Biol. 24:198-213.

Shapiro, M. D. 2002. Developmental morphology of limb reduction in Hemiergis (Squamata: Scincidae): Chondrogenesis, osteogenesis, and heterochrony, J. Morphol. 254:211-231.

Shapiro, M. D.; Hanken, J.; Rosenthal, N. 2003. Developmental basis of evolutionary digit loss in the Australian lizard Hemiergis. J. Exp. Zoo. (Mol Dev Evol) 297B:48-56.

Sheil, C. A. 2003. Osteology and skeletal development of Apalone spinifera (Reptilia: Testudines: Trionychidae). J. Morphol. 256:42-78. 
Sheil, C. A. 2005. Skeletal development of Macrochelys temminckii (Reptilia: Testudines: Chelydridae). J. Morphol. 263:71-106.

Sheil, C. A.; Greenbaum, E. 2005. Reconsideration of skeletal and ossification of Emydura subglobosa (Testudines, Pleurodira, Chelidae) and patterns of turtle development. Dev. Dynam. 238:2770-2786.

Sheil, C. A.; Portik, D. 2008. Formation and ossification of limb elements in Trachemys scripta and discussion of autopodial elements in turtles. Zool. Sci. 25: 622-641.

Shine, R. 1983. Reptilian reproductive modes: the oviparity- viviparity continuum. Herpetologica, 39:1-8.

Shine, R.; Harlow, P. S. 1996. Maternal manipulation of offspring phenotypes via nest-site selection in an oviparous reptile. Ecol. 77:1808-1817.

Shubin, N. H. 2002. Origin of evolutionary novelty: examples from limbs. J. Morphol. 252: $15-28$.

Shubin, N. H.; Alberch, P. 1986. A morphogenetic approach to the origin and basic organization of the tetrapod limb. Evol. Biol. 20: 318-390.

Shubin, N. H.; Tabin, C.; Carroll, S. 2009. Deep homology and the origins of evolutionary novelty. Nature 457:818-823.

Shubin, N.; Tabin, C.; Carroll, S. 1997. Fossils, genes and the evolution of animal limbs. Nature 388:639-648.

Shumway, W. 1940. Stages in the normal development of Rana pipins. Anat. Rec. 78: 139147.

Silva, C. M.; Verrastro L. 2007. Descrição do esqueleto axial de Liolaemus arambarensis Verrastro, Veronese, Bujes \& dias Filho (Iguania, Liolaemidae): regiões pré-sacral e sacral. Rev. Bras. Zool. 24:1-11.

Simões-Lopes, P. C. A.; Krause, L. 1988. Osteologia do sincrânio de Liolaemus occipitalis Boulenger, 1885 (Sauria, Iguanidae). Rev. Bras. Zool. 5:491-508.

Skinner, M. M. 1973. Ontogeny and adult morphology of the skull of the South African skink Mabuya capensis (Gray). Ann. University of Stellenbosch. 48:1-116.

Smith, K. K. 1997. Comparative patterns of craniofacial development in eutherian and metatherian mammals. Evolution 51: 1663-1678. 
Soemmerring, S. T. 1799. Icones embryonum humanorum. Frankfurt am Main: Varrentrapp und Wenner.

Stayton, C. T. 2005. Morphological evolution of the lizard Skull: A geometric morphometrics survey. J. Morphol. 263:47-59.

Stephenson, N. B.; Stephenson, M. 1956. The osteology of New Zealand geckos and its bearing on their morphological status. Trans. R. Soc. New Zealand. 84:341-385.

Stephenson, N. G. 1960. The comparative osteology of australian geckos and its bearing on their morphological status. Zool. J. Linn. Soc. 44:278-299.

Stokely, P. S. 1950. The occurrence of an intermedium in Lizards. Am. Midl. Natural. 43:179-182.

Storer, T. I.; Usinger, R. L.; Stebbins, R. C.; Nybakken, J. W. 2005. Zoologia Geral. Companhia Editora Nacional, São Paulo.

Swanson, P. L. 2004. The iguana: Iguana iguana iguana. Iguana. 11:179-182.

Tarazona, O. A.; Fabrezi, M.; Ramírez-Pinilla, M. P. 2008. Cranial morphology of Bachia bicolor (Squamata: Gymnophthalmidae) and its postnatal development. Zool. J. Lin. Soc. 152:775-792.

Tedesco, M. E.; Krause, L.; Alvarez, B. B. 1999. Descripción del sincraneo de Ameiva ameiva (Linnaeus) (Squamata, Teiidae). Rev. Bras. Zool.16:1025-1044.

Thompsom, M. B.; Russel, K. J. 1999. Embryonic energetics in eggs of two species of Australian skink, Morethia boulengeri and Morethia adelaidensis. J. Herpetol. 33:291-297.

Thorogood, P. 1983. Morphogenesis of cartilage. In: Hall, B. K. (ed.) Cartilage: Development, differentiation and growth. Vol. 2. New York: Academic Press. p 223-254.

Throckomorton, G. Y. S. 1976. Oral food processing in two herbivorous lizards, Iguana iguana (Iguanidae) and Uromastix aegyptus (Agarnidae). J. Morphol. 148: 363-390.

Tian-Miao, H.; Chao-lin, W.; Bi-Hui, C. 2004. Stages of embryonic development for Alligator sinensis. Zool. Res.

Titus, T. A.; Frost, D. R. 1996. Molecular homology assessment and phylogeny in the lizard family Opluridae (Squamata: Iguania). Mol. Phyl. Evol.. 6:49-62.

Tokita, M.; Kuratani, S. 2001. Normal embryonic stages of the Chinese softshelled turtle Pelodiscus sinensis (Trionychidae). Zool. Sci.18: 705-715. 
Torres-Carvajal, O. 2003. Cranial osteology of the Andean lizard Stenocercus guentheri (Squamata: Tropiduridae) and its postembryonic development. J. Morphol. 255:94-113.

Torres-Carvajal, O. 2004. The abdominal skeleton of tropidurid lizards (Squamata: Tropiduridae). Herpetologica 60: 75-83.

Townsend, T .M.; Larson, A.; Louis, E.; Macey, J. R. 2004. Molecular phylogenetics of Squamata: the position of snakes, amphisbaenians, and dibamids, and the root of the squamate tree. Syst. Biol. 53:735-757.

Van Damme, R.; Bauwens, D.; Braña, F.; Verheyen, R. F. 1992. Incubation temperature differentially affects hatching time, egg survival and sprint speed in the lizard Podarcis muralis. Herpetologica 48:220-228.

Vargesson, N.; Kostakopoulou, K.; Drossopoulou, G.; Papageorgiou, S.; Tickel, C. 2001. Characterization of Hoxa gene expression in the chick limb bud in response to FGF. Dev. Dynam. 220:87-90.

Vickaryous, M. K.; Olson, W. M. 2007. Sesamoids and ossicles in the appendicular skeleton. In: Hall, B. K. (ed.): Fins Into Limbs: Evolution, development, and transformation. Part III: Transformation. University of Chicago Press, Chicago.

Vidal, N.; Hedges, S. B. 2005. The phylogeny of squamate reptiles (lizards, snakes, and amphisbaenians) inferred from nine nuclear protein-coding genes. Comptes Rendus Biologies 328: 1000-1008.

Vieira, L. G. 2011. Desenvolvimento embrionário de Melanosuchus niger (Crocodylia, Alligatoridae): Descrição de estágios e ontogenia do esqueleto. Tese (Doutorado em Biologia Animal). Universidade de Brasília.

Vieira, L. G.; Lima, F. C.; Santos, A. L. Q.; Mendonça, S.H. S. T.; Moura, L. R.; Iasbeck, J. R.; Sebben, A. 2011. Description of the embryonic stages in Melanosuchus niger (Spix, 1825) (Crocodilia: Alligatoridae). J.Morphol. Sci. 28: 11-22.

Vieira, L. G.; Santos, A. L. Q. Lima, F. C. 2010. Ontogeny of the cranial bones of the giant amazon river turtle Podocnemis expansa Schweigger, 1812 (Testudines, Podocnemididae) Acta Scientiarum: Biol. Sci. 32:181-188.

Vieira, L. G.; Santos, A. L. Q.; Lima, F. C. 2007. Ontogeny of scleral ossicles of giant amazon river turtle Podocnemis expansa Schweigger, 1812 (Testudines, Podocnemididae). Braz. J. Morphol. Sci. 24:220-223.

Vieira, L. G.; Santos, A. L. Q.; Lima, F. C.; Moura, L. R. 2011. Chondrogenesis of the 
limbs and mesopodial ossification of Podocnemis expansa Schweigger, 1812 (Testudines: Podocnemidae), J. Morphol. 272:404-418.

Viets, B. E.; Tousignant, A.; Ewert, M, A.; Nelson, C. E.; Crews, D. 1993. Temperaturedependent sex determination in the leopard gecko, Eublepharis macularius. J. Exp. Biol. 265: 679-683.

Vitt, L. J.; Pianka, E. R.; Cooper, W. E.; Schwenk, K. 2003. History and the global ecology of squamate reptiles. Am. Natural. 162:44-60.

Wagner, E. F.; Karsenty, G. 2001.Genetic control of skeletal development. Genet. Dev. 11:527-532.

Wagner, G. P.; Chiu, C. 2001. The tetrapod limb: A hypothesis on its origin. J. Exp. Zoo. (Mol Dev Evol) 291:226-240.

Walls, G. L. 1942. The Vertebrate eye and its adaptive radiation. Cranbrook Inst Sci Bull 19:1-785.

WeiseL, G. F. 1967. Early ossification in the skeleton of the sucker (Catostomus macrocheilus) and the guppy (Poecilia reticulate). J. Morphol. 121:1-18.

Werneburg, I. 2009. A Standard System to Study Vertebrate Embryos. PLoS One 4(6): e5887.

Werneburg, I.; Hugi, J.; Müller, J.; Sánchez-Villagra, M. R. 2009. Embryogenesis and ossification of Emydura subglobosa (Testudines, Pleurodira, Chelidae) and patterns of turtle development. Dev. Dynam. 238:2770-2786.

Werneburg, I.; Sánchez-Villagra, M. R. 2009. Time of organogenesis support basal position of turtles in the amniote tree of life. Evol Biol 9:82.

Werner, Y. L. 1971. The ontogenetic development of the vertebrae in some gekkonoid lizards. J. Morphol. 133: 41-92.

White, D. G.; Hershey, H. P.; Moss, J. J.; Daniels, H.; Tuan, R. S.; Bennett, V. D. 2003. Functional analysis of fibronectin isoforms in chondrogenesis: Full-length recombinant mesenchymal fibronectin reduces spreading and promotes condensation and chondrogenesis of limb mesenchymal cells. Differentiation 71: 251-261.

Wise, P. A, D.; Vickaryous, M. K.; Russel, A. P. 2009. An embryonic staging table for in ovo development of Eublepharis macularius, the leopardo gecko. Anat. Rec. 292: 1198-1212.

Withers, P. C. 1992. Comparative animal physiology. Los Angeles: Brooks/Cole. 949 p. 
Wolpert, L.; Jessell, T.; Lawrence, P.; Meyerowitz, E.; Robertson, E. 2007. Principles of Development. Oxford, New York: Oxford University Press.

Woltering, J. M.; Duboule, D. 2010. The origin of digits: expression patterns versus regulatory mechanisms. Dev. Cell 18:526-532.

Yntema, C. L. 1968. A series of stages in the embryonic development of Chelydra serpentina. J. Morphol. 125: 219-251.

Young, R. L.; Caputo, V.; Giovannotti, M.; Kohlsdorf, T.; Vargas, A. O.; May, G. E,; Wagner, G. P. 2009. Evolution of digit identity in the three-toed Italian skink Chalcides chalcides: A new case of digit identity frame shift. Evol. Dev. 11:647-658.

Zehr, D. R. 1962. Stages in the normal development of the common garter snake, Thamnophis sirtalis sirtalis. Copeia 1962: 322-329.

Zeller, R.; Lopez-Rios, J.; Zuniga, A. 2009. Vertebrate limb bud development: moving towards integrative analysis of organogenesis. Nate. Rev. Genet. 10:845-858.

Zhang, G.; Boyle, D. L.; Zhang, Y. 2012. Development and mineralization of embryonic avian scleral ossicles. Mol. Vis. 18:348-361.

Zug, G. R.; Balazs, G. H.; Wetherall, J. A.; Parker, D. M.; Murakawa, S. K. K, 2001. Age and growth of Hawaiian green seaturtles Chelonia mydas: an analysis based on skeletochronology. Fish Bull. 100:117 127.

Zug, R. G. 1993. Herpetology, An Introduction Biology of Amphibians and Reptiles: Washington: Academic Press. 527p.

Zylberberg, L.; Geraudie, J.; Meunier, F.; Sire, J-Y. 1992. Biomineralization in the integumental skeleton of the living lower vertebrates. In: Hall, B. K. (ed.) Bone. Vol. 4. Bone metabolism and mineralization. Boca Raton, FL: CRC 